CREOLE LANGUAGE LIBRARY

\title{
Afro-Peruvian Spanish
}

Spanish slavery and the legacy of Spanish Creoles

Sandro Sessarego 
Afro-Peruvian Spanish 


\section{Creole Language Library (CLL)}

ISSN 0920-9026

A book series presenting descriptive and theoretical studies designed to add significantly to the data available on pidgin and creole languages.

All CLL publications are anonymously and internationally refereed.

For an overview of all books published in this series, please see http://benjamins.com/catalog/cll

\section{Editors}

Miriam Meyerhoff

Victoria University of Wellington

\section{Editorial Advisory Board}

Mervyn C. Alleyne

Kingston, Jamaica

Marlyse Baptista

Ann Arbor, USA

George L. Huttar

Dallas, USA

John Holm

Coimbra, Portugal

Silvia Kouwenberg

Kingston, Jamaica

Susanne Michaelis

Leipzig, Germany

Salikoko S. Mufwene

Chicago, USA
Umberto Ansaldo

The University of Hong Kong

Pieter Muysken

Nijmegen, The Netherlands

Peter Mühlhäusler

Adelaide, Australia

Shobha Satyanath

Delhi, India

John Victor Singler

New York, USA

Norval Smith

Amsterdam, The Netherlands

Sarah G. Thomason

Ann Arbor, USA

Tonjes Veenstra

Berlin, Germany

\section{Volume 51}

Afro-Peruvian Spanish. Spanish slavery and the legacy of Spanish Creoles by Sandro Sessarego 


\section{Afro-Peruvian Spanish}

Spanish slavery and the legacy of Spanish Creoles

Sandro Sessarego

University of Texas, Austin

John Benjamins Publishing Company

Amsterdam / Philadelphia 
The paper used in this publication meets the minimum requirements of the American National Standard for Information Sciences - Permanence of Paper for Printed Library Materials, ANsI z39.48-1984.

DOI 10.1075/cll.51

Cataloging-in-Publication Data available from Library of Congress: LCCN 2015029384 (PRINT) / 2015034183 (E-BOOK)

ISBN $9789027252753 \quad(\mathrm{HB})$

ISBN 9789027267764 (Е-вОок)

An electronic version of this book is freely available, thanks to the support of libraries working with Knowledge Unlatched. $\mathrm{KU}$ is a collaborative initiative designed to make high quality books Open Access for the public good.

The Open Access isbn for this book is 9789027267764 .

(C) 2015 - John Benjamins B.V.

This e-book is licensed under a Creative Commons CC BY-NC-ND 4.o license. To view a copy of this license, visit https://creativecommons.org/licenses/by-nc-nd/4.o/. For any use beyond this license, please contact the publisher.

John Benjamins Publishing Company · https://benjamins.com 
Per il mio amico Bill 



\section{Table of contents}

List of figures $\quad$ XI

List of tables $\quad$ XIII

Acknowledgments $\quad$ XV

CHAPTER 1

\section{Introduction}

1.1 General introduction $\mathbf{1}$

1.2 Objectives of this study 2

1.3 Data collection 3

1.4 Organization of the volume 3

\section{CHAPTER 2}

The Spanish creole debate

2.1 Introduction 5

2.2 Did the Spanish creoles decreolize? 6

2.3 The lack of Spanish creoles in the Caribbean: Demographic and economic factors $\mathbf{1 0}$

2.4 The lack of Spanish creoles on the Mainland: The Afrogenesis Hypothesis $\mathbf{1 3}$

2.5 The place of this study in the Spanish creole debate $\quad \mathbf{2 1}$

CHAPTER 3

A description of Afro-Peruvian Spanish grammar

3.1 Introduction 23

3.2 Peruvian Spanish varieties 23

3.2.1 Andean highlands 24

3.2.2 Lima/central coast 24

3.2.3 Northern coast 25

3.2.4 Southern coast / south-western Andean region $\quad 25$

3.2.5 Amazonian lowlands 25

3.3 A phonetic account of Afro-Peruvian Spanish $\quad 26$

3.3.1 Vowels 26

3.3.2 Consonants 30

3.3.3 Intonation patterns 39 
3.4 Afro-Peruvian Spanish morpho-syntax 40

3.4.1 Noun Phrase 40

3.4.2 Verb Phrase 48

3.4.3 Prepositional Phrase 53

3.4.4 Phrase-level constructions 55

3.5 Lexical items in Afro-Peruvian Spanish $\quad 59$

3.6 A final note on Afro-Peruvian Spanish grammar $\mathbf{6 1}$

CHAPTER 4

The status of Afro-Peruvian Spanish

4.1 Introduction $\mathbf{6 3}$

4.2 Creoles as Interlanguages 65

4.3 The proposal 66

4.4 The Afro-Hispanic varieties of the Americas $\quad 67$

4.5 Afro-Peruvian Spanish as an advanced conventionalized second language 71

4.6 A final note on the status of Afro-Peruvian Spanish and other Afro-Hispanic contact varieties 77

CHAPTER 5

Black slavery in Peru

5.1 Introduction 79

5.2 Slavery in the Spanish world before and during the American conquest 80

5.3 Conquest and colonization (1530-1650) $\mathbf{8 1}$

5.4 Second phase (1650-1776) 97

5.5 Third phase (1776-1970) 111

5.6 Sugar plantations in Chincha $\mathbf{1 1 3}$

CHAPTER 6

Solving the Spanish creole puzzle: The legal hypothesis of creole genesis

6.1 Introduction $\mathbf{1 1 7}$

6.2 The Legal Hypothesis of Creole Genesis, a synopsis $\mathbf{1 2 0}$
6.2.1 Roman slave law $\mathbf{1 2 1}$
6.2.2 Spanish slave law 123
6.2.3 English slave law $\mathbf{1 2 6}$
6.2.4 French slave law $\mathbf{1 2 9}$
6.2.5 Dutch slave law 131
6.2.6 Portuguese slave law 133 
6.3 How did legal personality affect Spanish slaves' living conditions? 134

6.3.1 Historical remarks on Spanish slavery in the Americas 135

6.3.2 The legal practice of Spanish slavery 139

6.3.3 Back to Peru 145

6.3.4 Three case studies to test the Legal Hypothesis of Creole Genesis $\quad 147$

6.3.4.1 Cuba 147

6.3.4.2 Barbados and South Carolina 150

6.3.4.3 Chocó 152

6.4 The Legal Hypothesis of Creole Genesis in the context

of Afro-European contact varieties in the Americas 156

CHAPTER 7

Concluding remarks

References

Index 



\section{List of figures}

Figure 1.1 Overhead view of Chincha, Peru (adopted from: <https://www.google.com/ maps/@-10.9603117,-75.8046736,6z>)

Figure 3.1 Multiple early-aligned peaks and minimal downstep across non-exclamatory non-focused declaratives

Figure 3.2 Gender agreement evolution in APS

Figure 4.1 A continuum of outcomes involving degrees of substrate and L2 input (Winford 2000:216)

Figure 4.2 The Afro-Hispanic regions of Latin America (Klee \& Lynch 2009: 6, adopted from Perl \& Schwegler 1998:3)

Figure 5.1 A Spanish conquistador with his black servant (Guman Poma de Ayala 1615) 83

Figure 5.2 A black servant helping a Spanish corregidor de indios punish a native (Guman Poma de Ayala 1615)

Figure 5.3 Slave trade routes to Peru (adapted from <http://www.lib.utexas.edu/ maps/americas/latin_america.gif $>$ )

Figure 5.4 A pregonero selling bread (Periodismo en el Perú 2012)

Figure 5.5 Slave purchases (1770-1801) (Flores Guzmán 2003:22)

Figure 5.6 Jesuit haciendas in coastal Peru (Cushner 1980:ii)

Figure 5.7 Overhead view of San Regis, San José, El Guayabo and El Carmen (adapted from: <https://www.google.com/maps/@-13.5047264,-76.0683455,15z>) 



\section{List of tables}

Table 2.1 Distribution of the estimated slaves in Spanish America (Clements 2009: 70) 12

Table 3.1 Cross-generational variable rule analysis of the contribution of internal factors to the probability of lack of gender agreement in Afro-Peruvian Spanish $($ Total $=2455 ;$ Log likelihood $=-210.896$; Total Chi-square $=$ 5.2353; Chi-square/cell $=0.8725$; Significance $=0.000$; Input $=0.007$ )

Table 4.1 Five commonly reported Afro-Hispanic features traditionally ascribed to a previous creole stage

Table 4.2 Common Afro-Hispanic features found in Afro-Peruvian Spanish

Table 5.1 Biography of Juan García (Restall 2000: 186)

Table 5.2 Biography of Juan Valiente (Restall 2000: 187)

Table 5.3 Countries of origin of a sample of slaves sold in Lima (1560-1650) (Bowser 1974: 73)

Table 5.4 Population demographics for Lima in 1600 (Bowser 1974: 340)

Table 5.5 Population demographics for Lima in 1614 (Bowser 1974:340)

Table 5.6 Population demographics for Lima in 1619 (Bowser 1974:340)

Table 5.7 Population demographics for Lima in 1636 (Bowser 1974:341)

Table 5.8 Population demographics for Lima in 1636 (Bowser 1974:95)

Table 5.9 Demographic figures for the city of Potosí (Crespo 1995:28)

Table 5.10 Average growth of slave population in the eight major haciendas, 1665-1767 (Cushner 1980: 89)

Table 5.11 Slaves' births and deaths in four haciendas (Cushner 1980:102)

Table 6.1 Slaves sold in Popayán 1690-1789 (\% according to their age) 



\section{Acknowledgments}

I owe the completion of this book to several people who supported me in a variety of ways during its preparation. I wish to thank all the Afro-Peruvians who helped me during my fieldwork in Chincha in the winter of 2012. In particular, I owe my gratitude to Rolando Palma Quiroz, who introduced me to many elderly Afro-Peruvian speakers. Fundamental for my investigation was the support of Alessandro Garro and Jocelyne Couchy, two friends I met in Peru during my stay.

I received valuable help by María del Carmen Cuba, who generously provided me with a copy of her book on Chincha Spanish, El Castellano Hablado en Chincha. I am very grateful for the comments made by reviewers of the first drafts of this study and of several related articles, which have appeared in specialized journals such as Iberia, Spanish in Context, and the Journal of Pidgin and Creole Languages. Among them were Armin Schwegler, John Lipski, José Andrés-Gallego and John McWhorter. Several ideas included in this book have emerged during informal conversations I had with other scholars and friends such as Peter Bakker, Eeva Sippola, Danae Pérez-Inofuentes, Laura Álvarez López, Donald Winford, Fernando Tejedo, David Korfhagen, Tonjes Veenstra, Francesco Caviglia, Daniela Salcedo, Javier Gutiérrez-Rexach, Melvin González-Rivera, Letania Ferreira, Carlo and Sergio Paolessi, Cathy Stafford, Diana Frantzen, Magda Davoli, Magda Ahmed, Irene Muzio, Rafael Orozco, Jeremy King, Rey Romero, Lisa Philip, Keith Vetter, Franco Scarano, Pablo Gómez, Elena D’Onghia, Ksenija Bilbija, Humberto and Lilia Valdez, Ian Williamson, Grant Armstrong, Mario Loyola, Loredana Comparone, Alicia Cerezo Paredes, Aaron Tate, Francesco Mangano, Severino Albuquerque, Luca Bacchini, Pierpaolo Ianni, Massimiliano Gambardella, Giovanni Cristina, Paola and Carlo Forte, Luca Sessarego, Terrell Morgan, Rajiv Rao, Michel DeGraff and Juanito Ornelas de Avelar.

I would like to thank the University of Texas at Austin and in particular the Spanish and Portuguese Department and the Teresa Lozano Long Institute of Latin American Studies (LLILAS) for having provided me with a great academic environment to research the African Diaspora to the Americas from a variety of disciplines and points of view. I owe my gratitude to all my colleagues and students here at UT for having been extremely friendly and supportive during the time I have spent working at this institution. Special thanks go to Adrian RodríguezRiccelli, Cassandra Knaff, Whitman Suárez, Jeff Michno, Patrick Lawrence, Jeff 
Becker, Mary Kleba, Jossianna Arroyo-Martínez, Luis Cárcamo-Huechante, Barbara Bullock, Jacqueline Toribio, Dale Koike, Orlando Kelm, Sergio Romero, Lisa Mailloux, Chiyo Nishida, Madeline Sutherland-Meier, César Salgado, Héctor Domínguez-Ruvalcaba, Sonia Roncador, Jason Borge, Gabriela Polit, Kelly McDonough, Marilén Loyola, Cory Reed, Pablo Postigo Olsson, Naomi Lindstrom, Jill Robbins, Arturo Arias, Omoniyi Afolabi, Michael Harney, Lars Hinrichs, Juan Colomina-Almiñana and Nicole Guidotti-Hernández.

Finally, I wish to thank Umberto Ansaldo, Miriam Meyerhoff, two anonymous reviewers, and the publishing team of John Benjamins for their professionalism and help with the publication of this study. Thank you! 


\section{Introduction}

\subsection{General introduction}

The origin and evolution of the Afro-Hispanic dialects spoken in the Americas (Barlovento Spanish, Yungueño Spanish, Chota Valley Spanish, etc.) have long been at the center of linguistic debate and, at present, full light has yet to be shed on the topic. It is still unclear why we do not find Spanish creole languages in certain regions of Spanish America, while we can find such contact varieties in similar former colonies, which were ruled by the British, the French or the Dutch (McWhorter 2000; Lipski 2005; Schwegler 2010).

This book focuses on one such Afro-Hispanic variety, the Afro-Peruvian dialect spoken in rural areas of the province of Chincha, Department of Ica, coastal Peru, more precisely in the villages of San Regis, San José, El Guayabo and El Carmen (see Figure 1.1). This dialect is spoken by a few hundred people, elderly Chinchanos, descendants of the slaves taken to this region during the seventeenth century to work on plantations.

This investigation has been carried out with the belief that creole studies will benefit from an interdisciplinary approach that combines linguistic, sociohistorical, judicial, and anthropological insights. The need for a multidisciplinary perspective is particularly evident in the case of Afro-Peruvian Spanish (APS). While this dialect does not show the radical morphological reductions and substrate influence commonly found in creole languages, its importance in the study of transatlantic creole genesis has long been acknowledged by experts in the field (e.g. Lipski 1994a; McWhorter 2000). In fact, given the presence of sugarcane plantations at the time of the colony, as well as the extensive use of a black workforce on them, it may surprise that no significant traces of a creole language in the region are found today.

After a thorough analysis of the socio-historical background of Chinchano Spanish and an inspection of its main linguistic features, this book offers a new hypothesis to provide a fresh view on the long-lasting Spanish creole debate. In particular, this proposal focuses on a variety of legal aspects that made African slavery under Spanish rule different from that exercised by other colonial powers. 


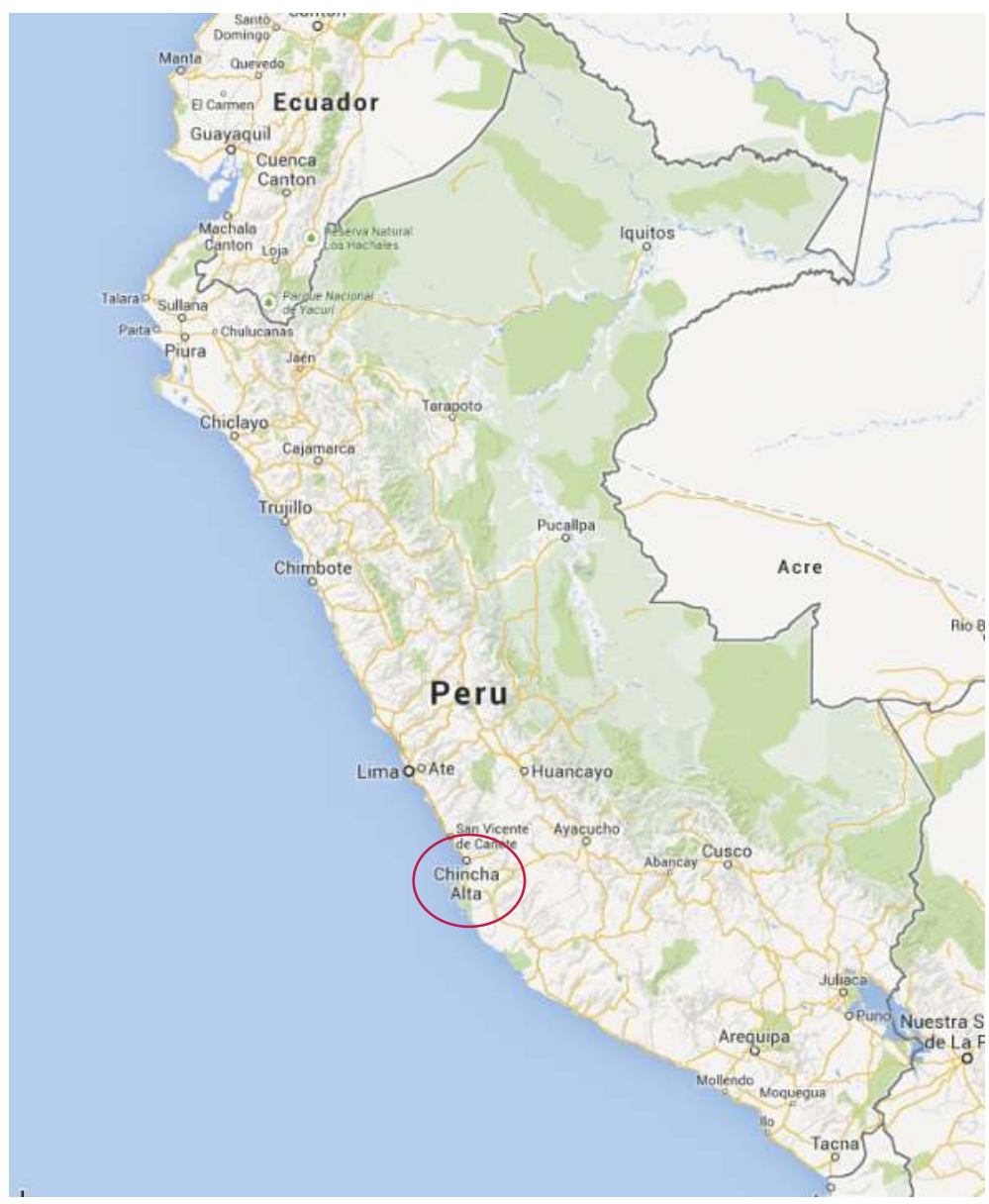

Figure 1.1 Overhead view of Chincha, Peru

(adopted from: <https://www.google.com/maps/@-10.9603117,-75.8046736,6z>)

\subsection{Objectives of this study}

This study has three main objectives. The first is to provide a socio-historical account of black slavery in Peru to unveil the origins of APS and to understand where to place this language in the Afro-Hispanic linguistic universe. The second objective is to describe APS grammar by focusing on its phonetics and phonology, morpho-syntax, and lexicon. The book then examines the Spanish creole debate from a comparative perspective and propose a new hypothesis to account for the current paucity of Spanish-based creoles in the Americas. 


\subsection{Data collection}

The fieldwork for this study was carried out from November 2012 to January 2013 in the rural villages of El Guayabo, San José, San Regis and El Carmen, located in the Province of Chincha, Department of Ica, Peru. Some sixty informants participated in this study. In collecting the data, I tried to select speakers belonging to different generations and with a variety of social and educational backgrounds. This heterogeneous sample of Chinchanos allowed me to understand that only the eldest and least educated informants could speak a dialect that presents several significant differences from standard coastal Peruvian Spanish. Even though several informants did not speak the traditional vernacular on a regular basis, almost everybody appeared to have some familiarity with it; thus they could corroborate with their grammatical intuitions the spontaneous data collected when speaking with the eldest members of the community.

In their daily informal interactions, grandparents would address younger people using remarkably traditional phonological and morpho-syntactic patterns. However, even in those circumstances, younger speakers would usually reply in the local standard. This apparent rejection of the traditional variety by the younger generations occurs in a sociolinguistic context in which the traditional Chinchano dialect is avoided in favor of a more prestigious Spanish variety. This suggests that, in one or two generations, APS is likely to be lost.

\subsection{Organization of the volume}

Chapter 1 provides a general introduction to the study by presenting its goals, methodology and structural outline. Chapter 2 introduces the main hypotheses that have been proposed to account for the relative paucity of Spanish creoles in the Americas. Chapter 3 provides an account of present-day APS grammar by focusing on its phonetics and phonology, morpho-syntax, and lexicon. Chapter 4 offers an analysis of the status of APS based on its grammatical features. It proposes that APS, as well as many other black dialects of the Americas, may be depicted as the result of $L 1$ acquisition (nativization) of advanced L2 grammars. Chapter 5 presents an analysis of black slavery in Peru. Chapter 6 addresses the persistent puzzle concerning the genesis and evolution of Afro-Hispanic contact varieties. It provides a comparative legal analysis of Spanish, English, French, Dutch and Portuguese colonies overseas to shed light on the paucity of Spanish creoles in the Americas. Finally, Chapter 7 consists of the concluding remarks. 



\section{CHAPTER 2}

\section{The Spanish creole debate}

\subsection{Introduction}

A long-lasting debate in Hispanic linguistics and creole studies concerns the origin and evolution of Afro-Hispanic contact varieties in the Americas. It is a wellknown fact that the current number of Spanish creoles in this region is much more reduced than the number of other European-based ones (e.g. derived from English and French). At a first glance, this fact may appear counterintuitive, especially if we consider that Spain was among the most influential imperial powers in the 'New World' and Spanish is today the official language of several Latin American countries. Nevertheless, as we can observe, Spanish creoles are not common in the Americas. Traditionally, only two languages have been classified as such: Papiamentu, spoken in the Dutch Antilles (Jacobs 2012), and Palenquero, used in the former maroon community of San Basilio de Palenque, Colombia (Schwegler 1996a). Furthermore, the study of the origin of these two varieties has given way to the opening of a quite heated debate, since for some scholars these languages are Spanish creoles only from a synchronic point of view, but not from a diachronic one (cf. McWhorter 2000: 14-20). In fact, it has been claimed that Papiamentu and Palenquero should be better analyzed as Portuguese-based creoles, which eventually went through Spanish relexification (see Goodman 1987; Schwegler 1993, 2014; Jacobs 2012; among others).

A variety of theoretical models have been formulated to account for this situation. For instance, the supporters of the Monogenetic Hypothesis of creole formation have suggested that an Afro-Portuguese creole spoken among black slaves once existed in the Spanish Caribbean and in several mainland colonies. According to this view, such a language survived only in Palenque and in the Dutch Antilles, having decreolized everywhere else due to standardization and pressure from normative Spanish (Granda 1968; Schwegler 1993). Conversely, other scholars ascribe the current lack of Spanish creoles in the Caribbean to a concomitance of demographic and economic factors, which differentiated this region from the French and British Antilles, and as a result, allowed the Spanish slaves to learn a good approximation to the language spoken by their masters (Chaudenson 2001; Laurence 1974; Mintz 1971). 
McWhorter (2000) agrees that Cuba, Puerto Rico and the Dominican Republic might not have been the ideal places for the development of a Spanish creole in colonial times; nevertheless, he affirms that the mainland colonies under Spanish rule would have been perfect for the development of such a language variety, but yet, Spanish creoles did not form there. In his view, the reasons for the scarcity of Spanish creoles in the Americas should not be sought in the Spanish American colonies themselves; rather, it should be ascribed to specific sociolinguistic conditions found in Africa, from where the slaves were shipped to the Americas (Afrogenesis Hypothesis). McWhorter (2000) argues that the creoles currently spoken in the Americas developed from pidgins, which formed in colonial times from the linguistic contact between the European traders and the Africans involved in the slave trade. Since Spain was the only European colonial power that did not trade directly in African slaves, a Spanish pidgin could never form on the Western African coast and, as a result, a Spanish creole could not possibly develop in the Americas.

The current chapter offers an account of the main hypotheses (and relevant critiques) that have been proposed to solve this long-lasting debate. This will provide a theoretical background on which to base our analysis of the APS case.

\subsection{Did the Spanish creoles decreolize?}

Germán de Granda $(1970,1978)$ was one among the first linguists to claim a genetic link among the Afro-Portuguese language varieties formed on the Western African coast and the Afro-Hispanic languages developed in the Americas. In fact, the author saw historical cues in Father Alonso de Sandoval's (1627 [1956]) treatise on slavery (DE INSTAURANDA AETHIOPUM SALUTE) suggesting the existence of a diffused Afro-Portuguese creole spoken among black slaves in Latin America.

This idea was perfectly in line with the proposal of other scholars working on different creole languages (e.g. Schuchardt 1889; Taylor 1961; Valdman 1964; Whinnom 1965; etc.), who claimed that the linguistic similarities among these varieties could not be due to chance, but rather derived from a common protolanguage (the Monogenetic Hypothesis, cf. Stewart 1962). In Granda's view, an early proto-Afro-Portuguese creole must have developed from the first contacts that the Portuguese had in Africa during the fifteenth century and then it must have been exported around the world through the different phases of European colonial expansion. According to this model, such a contact variety would have maintained its basic grammatical structure but its lexicon would have been relexified with lexical items proceeding from other languages. This would account for 
the fact that creole languages spoken in places so far apart and scattered around the world have relatively similar grammars. Granda (1968), in fact, claims that the morpho-syntactic similarities found across languages as typologically and geographically distant as Palenquero and Papiamentu (spoken in the Caribbean), the creoles from the Philippines, or the creole from Macau, among others, would be inexplicable if they were not accounted for by recurring to the Monogenetic Hypothesis. In his words, this fact would be "tan extraño como la invención paralela de un mismo sistema alfabético en múltiples y distantes puntos geográficos" (as strange as the parallel invention of the same alphabetic system in multiple and distant geographic locations) (1968:203).

Granda (1970), therefore, quotes a paragraph extracted from Sandoval's treatise and takes it as unequivocal evidence that masses of black slaves could speak a Portuguese creole in Spanish America: ${ }^{1}$

Y los que llamamos criollos y naturales de San Thomé, con la comunicación que con tan bárbaras naciones han tenido al tiempo que han resistido en San Thomé, las entienden casi todas con un género de lenguaje muy corrupto y revesado de la portuguesa que llaman lengua de San Thomé, al modo que ahora nosotros entendemos y hablamos con todo género de negros y naciones con nuestra lengua española corrupta, como comúnmente la hablan todos los negros.

(And those that we call creoles and natives of São Tomé, due to the communication that they had with so many uncivilized nations during the period they lived in São Tomé, understand almost all varieties, with a sort of broken Portuguese that they called the São Tomé language, so that now we can speak with all kinds of blacks with our corrupted Spanish, as it is usually spoken by all the blacks).

According to this view, given that a creole language was spoken in the Caribbean and in several other Spanish colonies, the current paucity of Spanish creoles in these regions would be due to a systematic process of decreolization, driven by standard Spanish normative pressure and language standardization. In fact, several authors suggest that certain linguistic traits currently found in the popular varieties of Spanish spoken in Cuba (Granda 1971; Otheguy 1973; Perl 1982, 1985; Megenney 1984, 1985, 1993), Puerto Rico (Granda 1968) and the Dominican Republic (Schwegler 1996b) should be seen as indicators of a previous creole stage (e.g. high rates of overt pronouns, non-inverted questions, double negation, etc.) (cf. Sessarego 2013b for a different account). Some of these authors, after analyzing historical and literary texts depicting the speech of slaves in colonial times, concluded that with all likelihood the language spoken by these black

1. For a different interpretation of Sandoval's words see Lipski (2005:288-289) and Sessarego (2013a). 
captives was not just a bozal ${ }^{2}$ variety of Spanish, but rather, a stable creole. One such author is Perl, who states for the Cuban case: "the Cuban 'habla bozal' was no idiolectally determined jargon of the Blacks in the 19th century but a social variety of Spanish comparable with other varieties of Spanish- and Portuguesebased creoles' (Perl 1982: 423, reported in Lipski 1993: 6).

Lipski (1987, 1993) holds a different opinion. He suggests that bozal Spanish never creolized in the Caribbean. In fact, he shows that the grammatical features ascribed by some authors to a potential previous creole stage for Caribbean Spanish may be seen as common second-language-acquisition strategies, not necessarily linked to a previous creole stage. Lipski acknowledges that the massive importation of an African workforce into Cuba during the sugar boom phase in the 19th century might have briefly set the conditions for language creolization on the biggest sugarcane plantations; nevertheless, he backs the idea that a stable creole never formed since the majority of the blacks already living on the island could speak Spanish. For this reason, the new captives, recently imported from Africa, did not creolize the local dialect and their offspring just learned the Spanish language natively.

Another case of decreolization has been proposed for Chota Valley Spanish (CVS), a black dialect spoken in Highland Ecuador. Schwegler $(1999,2014)$ ascribes to CVS a potential Afro-Portuguese creole origin. The author claims the existence in this language of a Portuguese third person pronoun, ele, which, in his view, would be hard to explain unless we assume that the slaves who entered Chota Valley in colonial times could speak a creole-like Afro-Portuguese contact variety (in partial support of the Monogenetic Hypothesis). Lipski (2009) provides a different account for the presence of ele in CVS. He analyzes this element as the result of a paragogic process of final $-e$ insertion affecting several items across the CVS lexicon (e.g. mujer $\rightarrow$ mujere, ayer $\rightarrow$ ayere, él $\rightarrow$ ele, etc.). Moreover, a closer analysis at the available socio-historical evidence for CVS highly reduces the possibility of a stable creole formation/introduction in the region, since a variety of demographic, economic, social, and religious factors at play on colonial Chota Valley plantations appear to have facilitated Spanish acquisition among the black slaves (Sessarego 2013c).

For the region of Barlovento, Venezuela, there have been claims suggesting a possible decreolization. Álvarez and Obediente (1998), in fact, have argued that some of the linguistic features encountered in the local black dialect might be

2. The term bozal refers to a second-language variety of Spanish. Bozales, in fact, were Africanborn slaves recently imported from Africa. On the other hand, the term latinos is generally used to refer to black slaves who were born in Spain or in the Americas, who spoke Spanish, and were familiar with Spanish cultural norms. 
ascribed to a previous creole stage (e.g. phonological reductions, non-inverted questions, etc.). Nevertheless, a deeper historical analysis has also shown that the constraints on slave importation into the region were quite strict and a big part of the enslaved population was locally born. Moreover, a linguistic inspection of all the 'creole-like' features has also revealed that the linguistic phenomena pointed out by Âlvarez and Obediente as potential creole indicators could be found in several other rural Spanish varieties, thus showing that they are not necessarily quintessential elements of creole languages (cf. Díaz-Campos \& Clements 2005, 2008).

In a recent study carried out in Palenque (Colombia), Schwegler and Morton (2003) have shown that the influence of Palenquero on the Spanish spoken in the region is minimal; thus, if Palenquero speakers decided to abandon their creole language, it would be virtually impossible to claim that a creole was once spoken in the region by looking at their variety of Spanish. The authors highlight this issue to claim that a creole language similar to Palenquero may have existed in several Afro-Hispanic communities across the Americas, and could have disappeared without leaving many traces behind. This is definitely a good point, which, I believe, further indicates that linguistic studies of this kind should always be corroborated by socio-demographic research to cast light on the history of these languages.

Another instance in which a decreolization account has been proposed is the Afro-Bolivian Spanish (ABS) case. ABS is spoken in the Yungas Valleys, Department of La Paz, Bolivia. Lipski (2008) was the first linguist to closely analyze this dialect and, given the morpho-syntactic reductions encountered in this variety, has suggested a potential creole origin for ABS. Nevertheless, more recently, socio-historical and linguistic evidence has been provided to refute the decreolization account of ABS in favor of a model depicting the features encountered in this dialect as the result of advanced second-language processes, which do not imply any previous creole stage (Sessarego 2011a, b, 2013d, 2014a).

As has been shown, different hypotheses have been provided to account for the current meager number of Spanish creoles in the Americas. For each country of interest, scholars have proposed ad-hoc explanations. However, a broader framework capable of accounting for the whole American continent has yet to be formulated. In fact, a distinction has gradually emerged in the linguistic literature to justify the non-creolization of these contact varieties. These studies have dealt with the Caribbean and the Mainland colonies in different ways, due to the different socioeconomic settings that characterized their colonial realities. In order to expose the main arguments dealing with the origin and evolution of Afro-Hispanic dialects in these two regions of the Americas, in the following sections I will maintain such a distinction; however, I must remind the reader that one of the goals of this study is to find common trends across the diverse colonial 
settings to eventually provide a single 'umbrella' framework capable of accounting in a broader sense for the birth and evolution of these language varieties. In line with this objective, a more general hypothesis will be presented, after putting together a puzzle of scattered data, in Chapter 6.

\subsection{The lack of Spanish creoles in the Caribbean: Demographic and economic factors}

The primary hypothesis that has been proposed in the literature on creole studies to account for the lack of creole formation in the Spanish Caribbean is that, in this part of the world, plantation societies developed only in the 19th century, contrary to what happened in the French and English Antilles, where large agricultural infrastructures relying heavily on an African workforce had been implemented two centuries earlier (Mintz 1971; Chaudenson 1992).

Since the economic structure of the Spanish Caribbean would have been based for several centuries on small- and medium-sized haciendas, the so-called société d'habitation (cf. Chaudenson 2001), where black bozales were never a significant majority and worked alongside whites and mestizos, ${ }^{3}$ the acquisition of the Spanish language by the enslaved group would have been facilitated (Mintz 1971; Megenney 1985). ${ }^{4}$ For this reason, in the 19th century the language spoken on these islands by the local population was Spanish. At that time, the implementation of a large-scale plantation system brought about radical changes in the mechanisms of production and involved the introduction of new African captives. Nevertheless, the arrival of a substantial African workforce did not entail the development of a Spanish creole (but see Schwegler 1996b, 1999 for a different view on Caribbean Spanish). Conversely, the new bozales, who did not outnumber the local population, simply learned the language spoken by the slaves who were already working on the islands (Lipski 1993, 1998). Such a scenario would have been quite different from the one encountered in the English and French Antilles. In fact, in these colonies the creolization of the European lexifiers did take place since the progressive and massive importation of slaves radically modified the demographic figures of the islands. In fact, the high rate of mortality among the captives implied the need for a constant introduction of new African laborers. From a language acquisition perspective, this system would entail that each new

3. A mestizo is a person of mixed White European and Amerindian ancestry.

4. It should be noted that on some islands in the Caribbean (i.e. St Kitts), a société d'habitation was present, and yet French creoles developed there (Baker \& Bruyn 1998). 
wave of slaves would eventually target a 'square approximation' (cf. Chaudenson 2001: 132) of the language targeted by the previous wave, thus resulting in a progressive shift of the language spoken on the plantation from the European lexifier.

Mintz (1971) and Laurence (1974) provide a list of social and economic aspects of slaves' lives in the Spanish Caribbean and contrast them with the living conditions of English and French captives. They indicate that, contrary to the English and French Caribbean societies, on the Spanish islands the ratio of slaves to freemen was low and manumission was quite easy to achieve, usually by means of coartación, a gradual self-purchased manumission. Moreover, it was common for white men and black women to have intimate relations, and mixed-race marriages were not exceptional. For these reasons, a free mulatto group, capable of speaking Spanish, quickly developed. Africans were never a majority group, especially before the 19th century, when they worked on small farms, side by side with white peones. Additionally, the hierarchical structure of society in the Spanish colonies was much more flexible than the one found in the French and English territories and, for this reason, Spanish slaves could more easily climb the social ladder. ${ }^{5}$

Lipski (1993, 1994b, 1998), Chaudenson (2001), and Mufwene (2001) restate that the external ecological conditions were not in place for the formation of a creole language under Spanish rule in the Caribbean. In particular, Chaudenson (2001) claims that the Spaniards managed to Hispanize the populations they colonized so that Spanish rapidly became the language spoken in Cuba, the Dominican Republic and Puerto Rico, and remained so for centuries. As a result of this strong Spanish cultural intake across all the social strata, even when masses of new Africans were brought to Cuba during the first decades of the nineteenth century, creolization did not take place.

One of the most detailed accounts on the non-creolization of Cuban Spanish is the one recently provided by Clements (2009:68-101) in his book The Linguistic Legacy of Spanish and Portuguese. In a chapter dealing with Bozal Spanish, the author offers a socio-historical analysis of the economic structure of colonial Cuba from 1492 to 1808 and the demographic evolution of its different ethnic groups. Clements (2009:70) begins his analysis by presenting Curtin's (1969: 8889) speculative data on the distribution of the imported slave force during the whole period of the Atlantic slave trade (see Table 2.1). Curtin's calculations estimate that almost $50 \%$ of all the slaves taken to Spanish America arrived via Cuba; thus, as Clements correctly points out, "it stands to reason that it would be here where we would expect to find the necessary conditions for the formation of a Spanish-lexified creole language" (2009:70).

5. Recent works by Wheat $(2009,2011)$ cast further light on the social stratification of Spanish colonial society. 
Table 2.1 Distribution of the estimated slaves in Spanish America (Clements 2009:70)

\begin{tabular}{lr}
\hline Country & Number \\
\hline Mexico & 200,000 \\
Cuba & 702,000 \\
Puerto Rico & 77,000 \\
Dominican Republic & 30,000 \\
Central America & 21,000 \\
Ecuador, Panama, Colombia & 200,000 \\
Venezuela & 121,000 \\
Peru & 95,000 \\
Argentina, Uruguay, Paraguay, Bolivia & 100,000 \\
Chile & 6,000 \\
Total & $1,552,000$ \\
\hline
\end{tabular}

Nevertheless, historical data show that, except for a short period around 1532, the black population never outnumbered the white one until 1811, when the sugarcane boom imposed the introduction of more blacks, who came to form 54.5\% of the population (cf. Masó 1976: 115; Clements 2009: 77). Clements (2009:78-79) also presents demographic data taken from Kiple (1976), which do not exactly match Masós analysis but appear to be for the most part in line with it. He compares the distributions of racial groups in Haiti and Cuba and states that (2009: 79):

Comparing the population distributions of different Caribbean islands, we see that the distribution of Cuba's population was more balanced than that of the other islands. For example, at the end of the eighteenth century (1972), Cuba had 54,152 (20 per cent) free colored, 84,590 (31 per cent) slaves, and 133,559 (49 per cent) whites. By contrast, around that time Haiti had 452,000 (98 per cent) slaves and 11,000 (2 per cent whites). ${ }^{6}$

6. Schwegler (p.c.) points out that, in his view, the actual (approximate) proportions of bozal vs. criollo slaves was not the most important factor in determining the genesis and evolution of creole languages. Rather, he indicates that what mattered the most was whether and how such slaves were grouped and housed. If, for instance, a plantation had $75 \%$ bozales, then it did not matter what the rest of Cuba had in terms of population mix. It would have been more than enough to create an "ideal situation" for pidginization/creolization. These observations are certainly correct; nevertheless, we should always try to build our hypotheses on the available evidence. Since we do not dispose of the exact percentages of bozales for each Cuban plantation, the information provided by Clements can be taken as a reliable indicator of the overall trend on the island. This, however, does not rule out the possibility that in some specific hacienda the situation might have been different. 
Clements highlights the key role played by the Spanish crown in limiting the introduction of slaves in colonial times and the consequently slow development of commerce until the second half of the eighteenth century. Due to the difficulties found by the settlers in importing black slaves, for several centuries Cuban commerce relied primarily on the production of goods that did not need a large workforce, such as tobacco and cattle raising (cf. Clements 2009: 81).

Finally, when commenting on the slaves' living conditions, Clements (2009:77-79) suggests that they were probably better in Cuba than in other European colonies. He reports Alexander von Humboldt's view on the matter (cited in Masó 1976:115) and indicates that the main factors making such a difference had to do with the higher numbers of manumissions, the emphasis posed on the Catholic religion, and the many advantages that domestic and skilled slaves could obtain from their masters.

\subsection{The lack of Spanish creoles on the Mainland: The Afrogenesis Hypothesis}

The socioeconomic structure of the Spanish Caribbean, as well as the evolution of its demographic figures over the colonial period, have usually been taken as evidence undermining a possible creole hypothesis for this region. McWhorter (2000) admits that such data may actually account for the lack of a Spanish creole development in the Antilles; nevertheless, in his view, if we accept the current assumptions on the formation of creole languages, then it is left to be explained why Spanish creoles are not spoken in the former Latin American mainland colonies, where massive African slave importations took place. In fact, the author argues that for several of these regions, large-scale agriculture was in place so that it should have created the optimal conditions for a creole to emerge.

McWhorter's (2000) book, The Missing Spanish Creoles, consists of a strong critique of the current assumptions on creole genesis and evolution; in particular, he criticizes what he labels the "limited access model," or the assumption that plantation creoles formed because slaves had little or no access to the superstrate language. McWhorter (2000:1) begins his study with the following words:

This book is written out of a conviction that creole genesis, at this writing, is a field on the brink of a serious mistake.

One would never know this from current creolist literature, in which the reigning tone is that the past thirty years have witnessed great progress in our understanding of creole languages. Indeed, creole studies is currently passing from its pre-paradigm stage - that is, the free-for-all of competing hypotheses typical 
of scientific inquiries in their infancy - into the maturity of a basic paradigm agreed upon by all (to borrow the terminology of Kuhn 1970).

The paradigm is one so deeply rooted in creolist thought that few would even consider it to be a position, as opposed to a verity (a prime sign that a paradigm has set in). The paradigm is what we will call the limited access model.

This model stipulates that the plantation creoles of the 'New World' and the Indian Ocean developed as a result of African slaves having had limited access to the lexifier spoken on plantations, due to the disproportion of blacks to whites in such settings. This concept depicts plantation creole genesis as an attempt by slaves to forge a viable lingua franca on the basis of unusually constrained input from a socially dominant lexifier. Thus plantation social structure is seen as having filtered lexifier input to most slaves.

In a field which prides itself upon its contentiousness, it will surprise many to hear that there is any fundamentally accepted tenet in creole studies. To be sure, no creolist subscribes explicitly to anything called the "limited access model." Most important, limited access is not the sum total of anyone's model - creole studies comprise a healthy variety of fascinating genesis theories. However, all work on plantation creole genesis uses some version of the limited access conception as a springboard.

In McWhorter's (2000) view, the limited access model of creole genesis is simply erroneous. It does not account for Spanish colonies and therefore it cannot explain such a "mysteriously absent creoles cluster under a single power" (2000:39). This would imply that "something broader was at work [in Spanish America] than just unconnected, local demographic constellations" (2000:39). In fact, if the limited access model were correct, then the Chocó region (Colombia), Chota Valley (Ecuador), Veracruz (Mexico), coastal Peru and coastal Venezuela would have been the perfect breeding ground for the development of Spanish-based creoles, but this was not the case.

If the lack of access to the lexifier was not the reason prompting creole evolution, then there must have been other factors at play. In contrast to Mufwene (1996), who sees creoles as restructured versions of their lexifiers, and Chaudenson (2001), who describes their evolution as the result of cyclical squared approximations to the European superstrate, McWhorter proposes that plantation creoles were once pidgins that were expanded into full-fledged languages by either children or adults (McWhorter 1997, 2000). As a result of this, Chaudenson's (1979, 1992) and Mufwene's (1996) frameworks, as well as those proposed by the creolists who subscribe to some version of the limited access model, would be seriously flawed. This is because such frameworks do not take into account the pidgin stage, which would be fundamental for the formation of plantation creoles in McWhorter's analysis. For this reason, the lack of Spanish creoles in the Americas would just be the logical consequence of the lack of Spanish pidgins on the 
other side of the Atlantic Ocean. Indeed, Spain, unlike the rest of the European colonies involved in the colonization of the Americas, did not directly trade in African slaves. Thus there were no Spanish slaving stations in Africa, and no Spanish pidgins could possibly be spoken on the African coast or transplanted to the Americas.

McWhorter does not claim that the demographic disproportions of blacks to whites found on American plantations did not play a role in creolization. What he actually affirms is that they could be conducive of creolization only if a previous pidgin was already in place. Therefore, the lack of Latin American Spanish creoles would just corroborate his Afrogenesis Hypothesis.

The author provides further data to support his model. He offers a linguistic and historical analysis of the evolution of Atlantic and Indian Ocean creoles and claims that all the English- and French-based varieties would have been derived from one French and one English pidgin respectively. The French pidgin would have formed on the Île the Bieurt, Senegal, where the French settled in 1638 (cf. Delafosse 1931: 111; McWhorter 2000: 173), while the English one is supposed to have developed in the Cormantin Castle, Ghana, where the English started trading in African slaves in 1632 (cf. Porter 1989: 128; McWhorter 2000: 111). These contact varieties would have been transplanted to several colonies around the world; thus this would also explain why these creoles show certain grammatical similarities that could hardly be accounted for in terms of substrate/superstrate influence and/or language universals.

McWhorter indicates that Africans expanded English and French pidgins into plantation creoles not because they did not have access to the European lexifiers; rather, they developed new means of communication because creoles came to represent a symbol of black identity for the slaves working in the fields. For this reason, African workers on colonial plantations would have had two different linguistic targets: the pidgin and the European lexifier. They would acquire the pidgin, thus participating in the making of a creole, to express black identity and, in some cases, they would also acquire a second-language variety of the European lexifier, to interact with whites. Conversely, since Spanish pidgins did not form in Africa, they could not possibly become a linguistic target on American plantations. For this reason, Spanish creoles never developed. The only available target on Spanish plantations was, therefore, just Spanish. Africans acquired this language and managed to encode black identity in it by recurring to phonological variation and African borrowings (McWhorter 2000:203-204). For this reason, present-day Afro-Hispanic vernaculars would be relatively similar to Spanish and would not show those radical differences from their lexifier that can be clearly observed in English- and French-based creoles. 
The Afrogenesis Hypothesis has not found much acceptance among linguists (e.g. Lipski 2000, 2005; Díaz-Campos \& Clements 2005, 2008; etc.). Even though McWhorter's effort to provide a unified framework to account for creole genesis has generally been praised (cf. Schwegler 2002: 121; Lipski 2005:286), his model and his data analysis have oftentimes been criticized.

Lipski (2005: Ch. 9) points out that from McWhorter's analysis it is not clear why pidgins would have formed in the African slaving stations but could not develop on the Spanish Latin American plantations - if the socio-demographic conditions on such plantations were really the ones described by McWhorter. Moreover, given that McWhorter claims that Papiamentu and Palenquero are two Portuguese-based creoles that have been relexified with Spanish words, it is also not clear why a similar relexification process would not have taken place in the Spanish Mainland colonies as well. Lipski also does not find the Afrogenesis Hypothesis solid from a socio-historical standpoint; rather, he indicates that it appears to be more inspired by the ideological position willing to proclaim creoles as the linguistic expression of black identity, rather than based on an accurate historical study.

Schwegler also points out significant shortcomings in McWhorter's hypothesis. In particular, he classifies as radical the view that all the Atlantic English-based creoles would have derived from one single shipment of slaves from the Conradin Castle, since "tracing West African pidgins to the Caribbean creoles has always been tempting, but no one has ever proposed a scenario in which a few dozen (or hundred) slaves on a single ship become the creators of such numerous and widespread contact vernaculars" (Schwegler 2002: 117). Schwegler also points out a few linguistic details mentioned by McWhorter that do not seem to be correct, such as the development of the predicate negation napa in Haitian and Mauritian creoles or the etymology of certain lexical items in Palenquero. Finally, he indicates that the socio-historical analysis for the Afro-Hispanic vernacular is, at times, overly categorical. In particular Schwegler (2002: 120) states that:

One can perhaps agree with him that the Chocó, the Chota Valley, Mexico, Venezuela and Peru may never have harbored a widespread Afro-Hispanic creole, but the absence of reliable historical and linguistic evidence makes it simply too risky to argue outright that the same territories had never imported an Afro-Iberian pidgin. The truth is that we simply do not know at this juncture whether such a contact vernacular was ever spoken anywhere in the Americas.

Indeed, it has to be said that McWhorter does not offer much socio-historical evidence to back his hypothesis. Díaz-Campos and Clements (2008) provide data showing that the account McWhorter suggests for the Venezuelan case does not reflect the reality of the facts. In fact, the demographic disproportions between 
Africans and Spaniards in colonial Venezuela were not as radically marked as McWhorter indicates; rather, many of the individuals that he classifies as "Africans" were actually mixed-race people born in the colony, who, in all likelihood, could speak Spanish natively. Díaz-Campos and Clements (2008) also show that the Black/White ratio was relatively low in Venezuela due the Spanish Crown's monopolization of the slave trade, which placed serious constraints on the introduction of an African workforce into the colony, thus indirectly reducing the probability of Spanish creole formation in the region.

McWhorter's description of the Ecuadorian scenario faces some sociohistorical problems as well. In fact, when describing Chota Valley slavery, the author (2000:10-11) claims that "there was no initial period of parity between black and white" and that African slaves were imported in massive cargoes. However, Coronel Feijóo (1991:81), a historian who studied the evolution of the Chota Valley population in colonial times, states that "hablar de importación masiva de negros, para la época, parece sobredimensionado; difícil resulta atribuir a los estancieros de la zona un negocio de tal magnitud" (talking about massive black importation, by that time, seems to be overstated; it is difficult to ascribe such a large-scale business to local settlers). Indeed, some blacks could be found in the region but planters relied, whenever possible, on a cheaper Indian workforce. In addition, two other authors, Peñaherrera de Costales and Costales Samaniego (1959), state that the introduction of an African workforce was gradual while, in a recent work, I have suggested that in all likelihood the majority of the blacks used on these plantations were criollos. Such a study also shows that the living conditions of blacks in Chota Valley might have differed from the conditions slaves experienced in other plantation settings throughout the Americas, particularly since social relations were more flexible and favored the acquisition of Spanish by the enslaved population (Sessarego 2013c: Ch. 2).

As for the other mainland regions mentioned by McWhorter to support his theory (Colombian Chocó, Veracruz, Mexico, and coastal Peru), some studies have been carried out to provide a description of the local Afro-Hispanic varieties; however, no detailed socio-historical analyses have ever been provided to account for their origin.

McWhorter (2000:7-10) maintains that, if we believe the limited access model, Colombian Chocó would have been the perfect place for a Spanish creole to develop. He argues that by 1778 the ratio of blacks to whites was 5,828:175, a mere 3 percent of whites. Working conditions were harsh and the access to Spanish was minimal since "slaves were forbidden to communicate with what freed blacks there were (West 1957:139-140), eliminating the latter as possible sources of Spanish input" (McWhorter 2000:8). Ruiz-García (2009) analyzes the main phonological and morpho-syntactic features found in the speech of a group of 
elder informants from Tadó, Department of Quibdó, Chocó, Colombia. The author, however, does not provide much information concerning the socio-historical background of this variety; thus she neither proves nor disproves McWhorter's claims and does not address the issues posed by the Afrogenesis Hypothesis. Nevertheless, Ruiz-García concludes that this language should be seen as the descendant of a bozal variety (rather than a creole), since its grammatical features can be analyzed as the result of second language acquisition strategies and limited grammatical restructuring, which do not imply any previous creole stage.

Another Afro-Hispanic dialect mentioned by McWhorter (2000:11) in support of the Afrogenesis Hypothesis is Afro-Mexican Spanish, spoken in isolated, rural communities in the proximity of Veracruz, Mexico, where masses of Africans were apparently imported to work on sugarcane plantations in the 1500 s to substitute the unsuitable Indian workforce (cf. Carroll 1991:62-65). Indeed, according to the author, a creole language also did not emerge in this case, since by looking at the data presented by Aguirre Beltrán (1958:208) in his ethnographic study, it can be seen that this variety closely resembles Spanish, as shown in (1).

(1) Ese plan tubo (<estubo) bien hecho ... pero si el gobierno atiende (la) lej, ba a causá $(<$ causar) gran doló $(<$ dolor $)$.

'That plan was well done, but if the government follows the law it will cause a lot of pain.'

It may be noted, however, that in a different study, Aguirre Beltrán (1946:20) clearly indicates that the majority of the slaves imported into Mexico were not coming directly from Africa; rather, they usually spent some time in previously settled Caribbean colonies, where they learned the Spanish ways; thus they were ladinos. This raises questions about the language variety that was used by the slaves introduced into colonial Mexico.

No linguistic monographs have ever been written on Afro-Veracrucian Spanish; for this reason no detailed historical and grammatical studies have been carried out to describe this dialect and its origin. The meager number of linguistic works on current Afro-Mexican varieties has also been pointed out by Lipski

7. In a recent sociohstorical study concerning the genesis and evolution of Chota Valley Spanish, it has been shown that the majority of the slaves sold in Popayán (the main slave market of the Chocó region during colonial times) were criollos (Sessarego 2013c: Ch. 2); this was true also for the most intense phase of slave force importation (1690-1789), when the percentage of bozales sold in Popayán totaled 41\% (Colmenares 1997:36). These data may lead to a sociolinguistic picture of Chocó that diverges quite significantly from the one hypothesized by McWhorter (2000:7-10). More research is needed to obtain a better idea of the potential for creole formation in colonial Chocó. 
(2007a), who provides an overall analysis of some phonological and morphosyntactic bozal features extracted from colonial Mexican texts. These works consisted of literary and theatrical passages where Spanish writers imitated, and oftentimes exaggerated, the speech of bozal slaves. Lipski (2007a:11) concludes his article by highlighting the need for future research concerning current AfroMexican dialects:

La historia completa de los contactos lingüísticos afrohispánicos en México está por escribirse; ofrecemos las observaciones anteriores con la esperanza de que no sean sino el primer paso en el camino que conduce a la investigación seria de la africanía lingüística de esta inmensa y diversa nación.

(The full history of the Afro-Hispanic linguistic contacts in Mexico has yet to be written; we offer the aforementioned observations hoping that they will serve as the first step toward a detailed investigation of the African factor in the linguistic evolution of the contact varieties of this huge and diverse nation).

To the best of my knowledge, the only book-length work on an Afro-Hispanic dialect of Mexico is the Ph.D. dissertation written by Mayén (2007), Afro-Hispanic linguistic remnants in Mexico, which provides a grammatical analysis of the vernacular spoken in the villages of Collantes and La Boquilla, Costa Chica, Province of Oaxaca. After carrying out linguistic fieldwork in the communities under investigation, the author suggests that the creole hypothesis may not be the correct one since the grammatical features reported also appear to be found in second-language varieties of Spanish and other non-standard dialects for which a creole stage was not likely. Nevertheless, Mayén does not carry out a detailed socio-historical analysis of the origin of this dialect since, as she states, due to the lack of published information on these villages, she had to rely mainly on "personal observation and on tape-recorded information from members of these Afro-Oaxacan communities” (2007:66).

As for coastal Peru, the last Latin American mainland region which would provide support to the Afrogenesis Hypothesis, McWhorter (2000: 12,35,37) offers only three paragraphs of socio-historical data. He states what follows:

Large forces of African slaves also worked sugar plantations in Peru, in coastal valley south of Lima (Bowser 1974). After emancipation, a large Afro-Peruvian community established itself in cities, retaining their cultural customs, and persisted until the turn of the twentieth century (Lipski 1994a:318). The Africanborn of this culture spoke a second-language ("bozal") Spanish, predictably, but blacks born in Peru simply spoke the local dialect of Spanish. More isolated Afro-Peruvian communities also survive on the coast today, who also preserve vigorous African influences in their culture. However, they speak nothing approaching a creole; their speech diverges only rather slightly in phonology from the local Spanish (Gálvez Ronceros 1975). 
In Peru [...] a given estate usually cultivated a variety of crops at one time and thus immediately required much more than a handful of slaves. In the early 1600 s, slave forces of more than 20 were typical, while some plantations had 40 or more slaves (Bowser 1974:89,94-95).

In Peru, manumission of plantation slaves was rare (Bowser 1974:298-300), corporal punishment was common (231), and religion was withheld even to the point of denying slaves their last rites (236).

Unfortunately, the current linguistic literature on Afro-Hispanic speech is also quite reduced with respect to Peru. The most cited studies are probably those by Romero (1987, 1988, 1994), which explore the main phonological patterns and lexical items of African origin found in Peruvian literary works and songs (from the seventeenth to the twentieth century). Romero's investigation is of great importance since it provides an account of Peruvian bozal talk, as depicted by local authors. The significance of this work is also pointed out by Lipski (1994a), who indicates that, even though white writers oftentimes exaggerated certain features of black speech in order to make fun of the African captives, certain morphosyntactic and phonological patterns must necessarily be accurate, since they recur systematically in a variety of texts.

Romero's studies do not attempt to provide a detailed socio-historical account for the genesis of Afro-Peruvian Spanish. The author also recognizes some methodological limitations concerning the collection of the data since no linguistic fieldwork was carried out in the Peruvian black communities and the research focused exclusively on written texts. Romero (1987:94, 1988: 18) states that:

En cuanto a lo que yo expongo a continuación, soy el primero en reconocer que tiene poco respaldo científico. No he podido formar los adecuados registros fonéticos de campo, de que aún carecemos. Preparar el esbozo que sigue ha sido el resultado de una penosa recopilación de las transcripciones literarias que se encuentran en obras, manuscritos y canciones peruanos de los últimos tres siglos, material del que no cabe esperar que contenga muy fieles reproducciones fonéticas del habla costeña.

(I have to admit that the materials I will present in this book are not backed by much scientific evidence. I was not able to collect the much-needed phonetic fieldwork data. The following work has been the result of a painstaking search and transcription of Peruvian literary works, manuscripts and songs from the past three centuries, materials which probably do not reflect any accurate phonetic reproduction of the actual Costeño speech).

Una sola persona no puede recorrer todos los centros poblados del Perú, que sería un método para obtener una información certera.

(One single person cannot visit all the Peruvian villages, which would be the proper way to collect the needed information). 
Cuba's (2002) work represents the first linguistic book on a currently spoken Afro-Peruvian dialect based on fieldwork research. The author carries out a sociolinguistic investigation in the Chinchano communities of El Guayabo, San José, San Regis and El Carmen and provides an analysis of the local dialect that focuses primarily on its phonetic and phonological traits. The author acknowledges that other aspects of this vernacular (e.g. morpho-syntax, lexicon) have not been extensively explored in her study and should be further analyzed (cf. 2002:38). In addition, she offers a sketch of the hacienda system in these communities; nevertheless, she does not address any of the questions posed by the Spanish creole debate. In particular, no mention of the Afrogenesis Hypothesis is made and the study does not attempt to provide an analysis of the origin of Chinchano Spanish; rather it focuses on some phonetic and phonological features that diverge from the local variety of standard Spanish.

\subsection{The place of this study in the Spanish creole debate}

A layout of the main hypotheses concerning the genesis and evolution of AfroHispanic contact varieties in the Americas, the so-called Spanish creole debate, has been provided. As it could be observed, much light has still to be cast on this issue, since consensus has not yet been achieved in the literature. Some scholars argued that an Afro-Portuguese creole language was once used among black slaves in Spanish America and then subsequently decreolized almost everywhere, thus surviving only in Palenque (Colombia) and in the Dutch Antilles (Granda 1968 et seq). Others have claimed that the demographic and economic conditions for creoles to emerge were not in place in the Spanish Caribbean, since the massive introduction of Africans took place only in the nineteenth century, when the majority of the blacks already found on the islands could speak Spanish (Mintz 1971; Laurence 1974; Lipski 1993; Chaudenson 2001).

A still different account is the one provided by McWhorter (2000). McWhorter, in fact, has suggested that the real reason why Spanish creoles are not present in Peru and in other former mainland colonies has to do with the fact that Spain was not directly involved in the slave trade, so that a Spanish pidgin never formed in Africa and, consequently, a Spanish creole could not possibly develop in the 'New World'. This hypothesis, in his view, would be the only way to explain the mysterious absence of creole varieties under a single power (2000:39). An overview of the main studies that have dealt with the Mainland regions mentioned by McWhorter in support of his model has been offered. We concluded that for some of them (Ecuador and Venezuela) historical data appear to disprove his hypothesis, while 
for others (Peru, Mexico, Colombia) not much research has been carried out but socio-historical cues do not seem to support the Afrogenesis Hypothesis either.

The current book contributes to a better understanding of the socio-historical scenario that characterized black slavery in Peru to understand to what extent the conditions for a creole to emerge might, or might not, have been in place in colonial times. This study also provides new linguistic data on APS and places this dialect in the broader context of Afro-Hispanic creole genesis. In addition to the socio-historical and linguistic analyses, this work offers a variety of legal insights into comparative slave laws in the Americas. In so doing, this book provides a new proposal (the Legal Hypothesis of Creole Genesis) to account for this "mysteriously absent creoles cluster under a single power" (McWhorter 2000:39). 


\section{A description of Afro-Peruvian Spanish grammar}

\subsection{Introduction}

This chapter provides an overview of the main grammatical features characterizing traditional Afro-Peruvian Spanish (APS). The Afro-Hispanic population studied in this work lives in rural communities located in the proximities of Chincha, on the southern Peruvian coast, more precisely in the villages of San Regis, San José, El Guayabo and El Carmen. For this reason, APS shows many of the features that characterize coastal dialects. At the same time, this variety presents linguistic patterns that deviate from those found in the surrounding dialects, but that can be commonly encountered in other Afro-Hispanic vernaculars spoken across the Americas.

Romero (1987) and Lipski (1994a, 2005) described the main features of AfroPeruvian grammar by analyzing literary works, theatrical texts, and traditional songs from the 17th-20th centuries reporting Peruvian bozal speech. On the other hand, Cuba (2002) offered the first synchronic account of APS by investigating the speech of the Afro-Chinchano communities mentioned above.

The present chapter will describe the main grammatical traits of APS, as they emerged during my fieldwork. The analysis will focus on APS phonetics and phonology, morphosyntax and lexicon. When appropriate, these features will be compared to the data offered by Romero, Cuba and Lipski. Before entering into the details of APS, the following section will provide a phonetic account of the main Spanish dialects spoken in Peru (cf. Lipski 1994b). This will help us locate APS in its surrounding dialectal context.

\subsection{Peruvian Spanish varieties}

Several authors have provided an account of the phonetic and phonological patterns characteristic of the main Peruvian Spanish dialects (Benvenutto Murietta 1936; Escobar 1988; Canfield 1981; etc.). In particular, Lipski (1994b) offered a comprehensive description of the major Spanish varieties spoken in this country. 
He divided Peru into four main dialectal zones: Andean highlands, Lima/central coast, Northern coast, southern coast/southwestern Andean region, and Amazonian lowlands. In the following paragraphs, I will present a brief sketch of Lipski's dialectological account for such areas to provide a general overview of the main Spanish varieties found in the country.

\subsubsection{Andean highlands}

a. The distinction between the phonemes $/ \mathrm{j} /$ and $/ \mathrm{K} /$ is maintained.

b. Cases of $/ \mathrm{n} /$ velarization and elision are common.

c. The phoneme / $\mathfrak{f} /$ is sometimes produced as a fricative $/ \mathrm{f} /$.

d. The phoneme $/ \mathrm{f} /$ in syllable final position is oftentimes produced as a voiceless sibilant.

e. The rhotic/r/ is usually produced as a fricative [ř $]$, especially in the southern regions of the country (e.g. Cuzco).

f. The sound $/ \mathrm{f} /$ may be pronounced as a fricative when is found in the onset clusters $/ \mathrm{tr} /, / \mathrm{pr} /, / \mathrm{kr} /$.

g. The sibilant $/ \mathrm{s} /$ is maintained and produced as [s].

h. The phonemes $/ \mathrm{d} /, / \mathrm{d} /, / \mathrm{g} /$ are generally maintained. Sometimes they are even pronounced as occlusive sounds when encountered in intervocalic position.

i. The fricative $/ \mathrm{x} /$ may be pronounced as a palatal before front vowels.

1. Unstressed vowel reduction is common.

$\mathrm{m}$. The sound /f/ may be pronounced as $[\mathrm{h}]$. Before unrounded vowels it may be pronounced as $\left[\mathrm{h}^{\mathrm{w}}\right]$.

n. Quechua-Spanish bilingual speakers may shift the stress of Spanish words to the penultimate syllable. Lipski (1994b:321) reports some examples provided by (Escobar 1988) such as corázon < corazón 'heart', platáno < plátano 'plantain'.

o. Spanish /e/ and /o/ are sometimes raised to /i/ and /u/ due to Aymara and Quechua influence.

\subsubsection{Lima/central coast}

a. The phonemic distinction between $/ \mathrm{j} /$ and $/ K /$ has been lost, so that Lima Spanish is considered a yeísta dialect.

b. $/ \mathrm{x} /$ is pronounced with a weak aspiration.

c. The sound /d/ in intervocalic position is oftentimes lost; to a lesser extent, also /b/ may be deleted.

d. The phoneme / $\mathfrak{t} /$ is generally maintained. 
e. Syllable-final $/ \mathrm{f} /$ is generally a tap or an alveolar fricative.

f. Syllable-final /s/ represents a strong sociolinguistic indicator in Lima. The phoneme /s/ is often weakened to [h] or elided altogether in the lowest social classes, while it tends to be preserved among the speakers belonging to higher social groups. Middle-class Limeños frequently aspire /s/ to [h] preconsonantly, while they maintain $[\mathrm{s}]$ in other phonological contexts. However, /s/ reduction in word final position has become more frequent in the younger generation.

g. $/ \mathrm{n} /$ is generally velarized.

\subsubsection{Northern coast}

The phonetic and phonological traits of this dialect resemble those encountered in the Lima/central coast region. Lipski (1994b:322) indicates that the main differences between these two varieties consists of a more pronounced weakening of consonant segments. Lipski, in fact, highlights the presence of higher levels of consonant reduction in coda position as well as a more marked debilitation of intervocalic $/ \mathrm{b} /, / \mathrm{d} /, / \mathrm{g} /$ and $/ \mathrm{j} /$. In the author's view, these phenomena are probably related to a more accentuated sociocultural marginality of the region.

\subsubsection{Southern coast / south-western Andean region}

This dialectal region does not present radical differences from the central and northern parts of the coast. The main features pointed out by Lipski are a less frequent velarization of $/ \mathrm{n} /$ and a stronger pronunciation of the sound $/ \mathrm{j} /$. The author also indicates that the older generation still maintains in certain cases the distinction $/ K / \mathrm{vs}$. $/ \mathrm{j} /$. However, it is quickly disappearing among the younger speakers.

\subsubsection{Amazonian lowlands}

Lipski indicates that in this area Spanish is often used as a second language. However, certain features can be systematically identified:

a. $/ \mathrm{j} /$ is produces as an affricate.

b. $/ \mathrm{x} /$ tends to be realized as a pharyngeal $[\mathrm{h}]$.

c. / / $\mathbb{t} /$ is often pronounced without occlusion.

d. Syllable-final /s/ tends to be weakened or elided altogether.

e. $/ \mathrm{r} /$ and $/ \mathrm{s} /$ are produced as $[\mathrm{r}]$ and $[\mathrm{r}]$ respectively. 
f. Intervocalic $/ \mathrm{b} /, / \mathrm{d} /, / \mathrm{g} /$ are often realized as occlusive sounds rather than [ß], [d], [y].

g. /f/ tends to be pronounced as $[\mathrm{h}]$ and $\left[\mathrm{h}^{\mathrm{w}}\right]$.

\subsection{A phonetic account of Afro-Peruvian Spanish}

As mentioned above, the Afro-Peruvian population studied in this work lives in the coastal region of Chincha. The main phonetic features encountered in APS are therefore those detailed for the dialectal zones depicted in Section 3.2.4. However, in APS we also encounter phonetic traits that are frequently found in other AfroHispanic dialects across Latin America and are not necessarily reported for the rest of the Peruvian coastal varieties.

Romero (1987:94) begins his description of the APS sound system by reminding the reader that he did not carry out direct fieldwork with Afro-Peruvian informants; rather, he relied exclusively on literary texts extracted from books, theatrical compositions and traditional songs from the 17th to the 20th centuries. For this reason, the author acknowledges that they should not be considered as a completely faithful representation of this speech. Lipski (1994a, 2005) provides an account of the APS phonetics and phonology by analyzing similar materials. He points out that, even though this information may not be completely accurate, certain patterns recur systematically across the corpora, thus indicating that some of the features identified in these studies belonged to the dialect used by Peruvian bozales. Another literary attempt to represent black Peruvian speech can be found in Gálvez Ronceros' novel (1975) Monólogo desde las tineblas 'Monologue from the darkness', which consists of a collection of stories taking place in contemporary Chincha. Some of these features have also been reported by Cuba (2002), who is the only author, to date, who has published linguistic results based on fieldwork investigation in Afro-Chinchano communities.

\subsubsection{Vowels}

(I) Vowel variation and lengthening

My fieldwork analysis revealed a general tendency toward vowel quality maintenance, even if in some cases I could find instances of vowel rising $/ \mathrm{o} / \rightarrow[\mathrm{u}]$, $/ \mathrm{e} / \rightarrow[\mathrm{i}]$. More common were the cases of vowel lengthening due to consonant loss (naa < nada 'nothing', pa comé < para comer 'in order to eat') (1). On the other hand, Romero (1987:101-102) highlights a certain degree of vowel variability, 
which he relates to the different vocalic values encountered in the African languages that were taken to the Peruvian coast. In the colonial texts he analyzed, in fact, the Spanish segment /o/ was not only represented orthographically with $<0>$ (oylemo < oiremos 'we will hear', compondlá < compondrá 'he will compose', fosico < hocico 'snout'); it could be encountered also as $<$ e $>$ (prenunciá $<$ pronunciar 'to pronounce', semos $<$ somos 'we are'), and especially $<\mathrm{u}>$ (currendo $<$ corriendo 'running', pulqué < por qué 'why', turu < todos 'all', cun $<$ con 'with', Jusepa $<$ Josefa 'Jusy', rumí < dormir 'to sleep', burica < borrica 'donkey', tesuro < tesoro 'treasure'). The sound /e/ presented orthographic variability too; it was reported as $<\mathrm{e}\rangle$ (pellico $<$ perico 'parakeet', moleniyo $<$ morenillo 'little black person', bel $<$ ver 'to see'), $<\mathrm{a}>$ (yebe $<$ llave 'key'), $<\mathrm{i}>$ (molinio $<$ moreno 'black'), and $<\mathrm{o}>$ (Josuclito $<$ Jesucristo 'Jesus Christ'). The vowel $/ \mathrm{i} /$ is found as $<\mathrm{i}>$ (viyancico $<$ villancico 'carol', Zuanico < Juanico 'John'), and $<\mathrm{e}>$ (cogé < cogí 'I took', senefica $<$ significa 'it means', memo $<$ mismo 'same'). The segment /u/ was reported as $<\mathrm{u}>$ (gulumbé $<$ gulumbá 'traditional song') and, more sporadically, as $<\mathrm{e}>$ (pentiro $<$ punter 'pointer'). The vowel /a/ was usually the most stable one (vamo < vamos 'we go', dilá < dirá 'she will say', Baltasale < Baltazar 'Baltazar'). Romero (1987: 102) also identifies several cases of diphthong reduction (engrio < engreído 'conceited', rir < reir 'to laugh', queto < quieto 'quiet', quero < quiero 'I want', currendo < corriendo 'running', nostla < nuestra 'our', contino < continuo 'to continue', individo < individuo 'individual', proba < prueba 'test', pode < puede 'he can', conciolo $<$ consuelo 'comfort') and many instances of resyllabification, resulting in vowel fusions and diphthongation (semiacabao < se me ha acabado 'I finished it', mestá haciendo < me está haciendo 'he is doing to me', quel < que él 'that he is', nuay < no hay 'there is not', nues < no es 'it is not', quiora < qué hora 'what time').

As for cases of vowel lengthening, my research appears to be more in line with previous investigations. In fact, Romero (1987: 107) and Lipski (1994a: 202) could also identify many instances of this phenomenon ( $i$ Eh frutée! $<$ iEh frutero! 'Hey fruit seller!', no tiee < no tiene 'she does not have', itamalée! < itamalera! 'tamale seller!', coosa < cosa 'what', ooye < oye 'listen', negriito < negrito 'little black person', tú me vaas a decí que coosa alias dicho < tú me vas a decir qué cosa le has dicho 'you are going to tell me what you told her', naa < nada 'nothing').

The cases of vowel lengthening and vowel rising found during my fieldwork on APS (2) have also been reported for past and present Afro-Hispanic varieties (3), and appear to be characteristic of rural Spanish worldwide. ${ }^{8}$

8. All the speech examples provided in this study have been collected during the fieldwork carried out by the author in Chincha communities, unless indicated otherwise. 
(2) a. Toditu [toditos] quieren trabajá [trabajar] en la ciudá[ciudad]. all want.PREs.3.PL work in the city 'Everybody wants to work in the city.'

b. Nu [no] he ví [visto] naa [nada], pero naa [nada] no AUX.PRES.1.sG seen nothing but nothing de naa [nada] digo. of nothing say.PREs.1.sG 'I have not seen anything, but absolutely nothing I say'.

c. Mucha genti [gente] ya no quieri [quiere] eso pa comée[comer]. many people already no want.PREs.3.sG this for eat 'Many people do not want to eat this anymore.'

(3) a. Nosotrus [nosotros] somos di [de] Caldera. we be.PREs.1.PL. of Caldera

'We are from Caldera.' (Chota Valley Spanish; Sessarego 2013c: 61)

b. Porque mucho año estuvi [estuve] yo al hospital. because many year be.PAST.1.sG I at-the hospital 'Because I spent a lot of time at the hospital.'

(Afro-Bolivian Spanish; Sessarego 2011a: 120)

c. AFRO-URUGUAYAN COPLA

Semo nenglu lindu [negros lindos]

be.PRES.1.PL black pretty

'we are pretty black people'

Semo vetelanu [veteranos]

be.PRES.1.PL veteran

'we are veterans'

$Y$ cum milicianu [con milicianos]

and with militiaman

'and with militiamen'

Quiliemi piliá [queremos pelear]

want.PREs.1.PL fight

'we want to fight'

(Afro-Uruguayan; Pereda Valdés 1965: 135-136, in Lipski 2008:75)

(II) Paragogic vowels

A feature often found in APS and in several other Afro-Hispanic dialects is the presence of paragogic vowels (mare < mar 'sea', vere < ver 'to see'), as shown in (4). Romero (1987: 141) identifies many instances of this phenomenon in the Peruvian bozal speech reported in the 17th-20th-century texts he analyzed (quereré < querer 'to want', mare < mar 'sea', Baltasale < Baltazar 'Baltazar', Melcholo < Melchor 'Melchor'). Romero suggests that this phenomenon may be due to the 
fact that many bozales spoke Kikongo languages, since in this linguistic family there is a strong tendency toward creating CV syllabic structures (cf. Bentley 1887:521). My findings are also in line with Lipski's (1994a, 2005), who reports several cases of paragogic vowels, especially in the texts from the 17th century (turrona < turrón 'nougat', ziolo $<$ señor 'sir', Diose/Dioso $<$ Dios 'God', belena $<$ belén 'nativity scene').

Paragogic vowels are also encountered in several other Afro-Hispanic languages (5). For example, it is a feature of Chota Valley Spanish (Lipski 2009; Sessarego 2013c), Afro-Bolivian Spanish (Lipski 2008; Sessarego 2011a) and Afro-Mexican Spanish (Lipski 2007a) to mention a few.

(4) a. Eyo iba a la playa para nadá en el mare [mar]. they go.PAST.3.sg to the beach to swim in the sea 'They were going to the beach to swim in the sea'.

b. Eso no va a volvere [volver]; ya no this no go.PRES.3.sG to come back already no vuelve.

come back.PRES.3.sG

'This will not come back; this is not going to come back anymore.'

c. La comunidá quiere justicia, pedir justicia the community want.PREs.3.sG justice ask for justice es normale [normal].

be.PRES.3.sG normal

'The community is asking for justice, asking for justice is normal, right?'

(5) a. Vamo a correré [correr], ¿qué me va go.PRES.1.PL to run what me go.PRES.3.SG

a hacere [hacer]?, le dio de comere [comer]. to do him give.PAST.3.sG of eat

'We are going to run, what do you want to do to me?, I gave him something to eat.'

(Afro-Mexican Spanish; Lipski 2007a:46)

b. Encontré a mi mujere [mujer] en la fiesta. meet.PAST.1.sG to my wife in the party 'I met my wife at the party'. (Chota Valley Spanish; Sessarego 2013c: 43)

c. Lo hacieron pegare [pagar], lu han hecho pegá. him made.PAST.3.PL beat him AUX.PRES.3.PL made beat 'They had him beaten, they had him beaten.'

(Afro-Bolivian Spanish; Lipski 2008:73) 


\subsubsection{Consonants}

(I) Weakening of syllable-final /s/

The sound /s/ is commonly aspirated and deleted in coda position (Dioh $<$ Dios 'God', casah < casas 'houses', tre < tres 'three', me < mes 'month'), in line with other costal Peruvian dialects (cf. Lipski 1994b:319-322). Lipski (1994a: 190) indicates that $/ \mathrm{s}$ / deletion and aspiration could be normally encountered in bozal speech, especially in 19th century works (bucá < buscar 'to look for', critiano < cristiano 'christian', sabemo < sabemos 'we know', tamale < tamales 'tamales'). My APS corpus is rich in data with this feature (6). These instances of consonant reduction are more clearly observed on words where /s/ does not represent a plural marker, since plural markers may be absent for syntactic reasons not related to /s/ weakening processes (see Section 3.4).

(6) a. Dioh noh [Dios nos] llama cuando quiere él. God us call.PREs.3.sG when want.PREs.3.sG he 'God calls us whenever he wants.'

b. Habia tre casah [trescasas] que ya nu hay. EXIS.PAST three houses that already no EXIS.PRES

'There were three houses that are not here anymore.'

c. Hace un me [mes] que no sé na de do.PRES.3.sg a month that no know.PREs.1.sG nothing of esah personah [esas personas].

these people

'I have not heard of these people for a month'.

Similar instances of /s/ weakening for contemporary APS have also been identified by Cuba (2002:26-27) (hata ahora < hasta ahora 'until now', tú tah viendo < tú estás viendo 'you are seeing', le pegan a uté < le pegan a usted 'they beat you'). Romero (1987:141) reports several cases for colonial bozal Spanish too (uté < usted 'you', ete < este 'this', equina < esquina 'corner', pecuezo < pescuezo 'neck', econder $<$ esconder 'to hide', decubres $<$ descubres 'you discover'). He also points out instances in which the word initial syllable /es/ is deleted altogether ( $t a<$ esta it is', taba < estaba 'it was', pañola < española 'Spanish', carapela < escarapela 'rosette'). Syllable-final /s/ weakening is a common phenomenon in Afro-Hispanic contact varieties (7), and, more generally, it can be encountered in several Latin American and Peninsular dialects (i.e. Caribbean Spanish, Andalusian Spanish, etc.).

(7) a. Treh [tres]; demá [demás]

three more

'Three'

(Afro-Bolivian Spanish; Sessarego 2011a:45) 

b. Vario día [varios días] several day 'Several days' (Barlovento Spanish; Megenney 1999: 168)
c. Somo [somos] loh doh [los dos] be.PAST.1.PL the two 'It is the two of us'

(Afro-Puerto Rican Spanish; Álvarez-Nazario 1974: 135)

(II) Loss of word-final/f/

The sound $/ \mathrm{f} /$ is oftentimes eliminated in coda position (mueto < muerto 'dead'; pueto $<$ puerto 'port'); especially in word-final position on infinitive verb forms (bailá < bailar 'to dance'; mirá<mirar 'to watch'; decí < decir 'to say'; bebé < beber 'to drink') (8).

(8) a. El día de la $h^{w}$ iesta la $h^{w} a m i l i a$ Vallumbrosio, todo la $h^{w} a m i l i a$ the day of the festival the family Vallumbrosio all the family se pone a bailá [bailar].

REFL put.PRES.3.SG to dance

'On the day of the festival the Vallumbrosio family, all the family dances.'

b. Ese señó [señor] ya ta mueto [muerto]. this man already be.PrEs.3.sG dead

'This man is already dead.'

c. Allá hay como un muelle, un pueto [puerto]. there EXIS.PREs like a pier a port 'Over there there is something like a pier, a port.'

Romero (1987: 104) and Lipski (1994a:201) report several similar cases (señó < señor 'sir', coló < color 'color', apretá < apretar 'to tighten', rezá < rezar 'to pray', temé < temer 'to fear', comé < comer 'to eat', viví < vivir 'to live', sufrí < sufrir 'to suffer', amará < amarrar 'to tie up', atá < atar 'to tie', clibi < escribir 'to write', cogé < coger 'to take', cosé < coser 'to sew'). Lipski points out that this phenomenon was relatively limited in early texts and became highly frequent in 19th century materials. Cuba (2002:33) points out the omission of $/ \mathrm{f} /$ on infinitive verbs, also when followed by enclitic pronouns (9).

(9) a. Querían sembralo [sembrarlo]. want.PREs.3.sG plant-it 'They wanted to plant it.'

b. No tenía que dale [darle] de comer a sus hijos. no have.PAst.3.sG that give-her of eat to her sons 'She should not have fed her sons.' 

c. Era pa'lumbrále [lumbrarle].
be.PAST.3.sG for illuminate-it
'That was done to illuminate it.'

Word-final / $/$ / reduction is also commonly found in other Afro-Hispanic vernaculars in the Americas (10).
(10) a. Doló [dolor]; amó [amor]; altá [altar].
Pain love altar
'Pain, love, altar' (Afro-Bolivian Spanish; Sessarego 2011a: 46)
b. Yo con él acabó de limpiá [limpiar].
I with he finish.PAST.3.sG of clean
'He and I finished cleaning' (Afro-Cuban Spanish; Ortiz López 1996: 90)
c. Sirbí [servir]; pidí [pedir].
serve-INF ask-INF
'To serve, to ask'

(Afro-Puerto Rican Spanish; Álvarez-Nazario 1974: 148)

\section{(III) Neutralization of $/ \mathrm{s} /$ and /d/ in syllable-initial position}

My corpus shows that intervocalic / $/$ / and $/ \mathrm{d} /$ are sometimes used interchangeably in onset position (toro < todo 'all', todo < toro 'bull', cara < cada 'each', cada < cara 'face'). This matches with the results by Romero (1987: 103-142), who reports a variety of cases where $/ \mathrm{f} /$ and $/ \mathrm{d} /$ may alternate in colonial texts (perí $<$ pedí 'I asked for', aronde < adonde 'where', empanara < empanada 'empanada', turu < todos 'all', tirito < todito 'all', dade < darle 'to give him', Madía < María 'María', cabayedo < caballero 'knight, cuedpo < cuerpo 'body', hoda < hora 'hour', dotoda < doctora 'doctor', dedecho < derecho 'law', agada < agarra 'to get', quiedo < quiero 'I want'). Lipski (1994a: 187), Donaire Vizarreta (1987:39-40), and Gálvez Ronceros (1975) provide a variety of data of this kind. Their examples are in line with the fieldwork findings by Cuba (2002:33) (ahoda < ahora 'now', yo eda repadidó < yo era repartidor 'I was the roundsman', se bajadon ellos $<$ se bajaron ellos 'they came down'). The alternation between $/ \mathrm{d} /$ and $/ \mathrm{f} /$ is common to many other AfroHispanic dialects (11) and it is also clearly noticeable in my APS corpus (12).

(11) a. Toravía [todavía]; todo [toro]; ayura [ayuda]

yet bull help

'Yet; bull; help' (Chocó Spanish; Ruiz-García 2009:72)

b. Ahoda [ahora]; Cadaca [Caracas]

now Caracas

'Now; Caracas' (Barlovento Spanish; Megenney 1999:77)

c. Toro [todo]; vira [vida]

all life

'All; life' (Afro-Puerto Rican Spanish; Álvarez-Nazario 1974: 116) 
(12) a. Toro [todo] parece mentira.

all look.PREs.3.sg lie

'Everything looks like a lie.'

b. Tiene una cada [cara] de monstruo.

have.PRES.3.sG a face of monster

'He has the face of a monster.'

c. La vira [vida] de ese hombre no tuvo na de alegría, the life of this man no have.PAST.3.sG nothing of joy $h^{w}$ ue una vira [vida] muy triste. be.PAST.3.sg a life very sad 'His life did not have any joy, it was a very sad life.'

\section{(IV) Neutralization of $/ \mathrm{s} /$ and $/ \mathrm{l} /$}

The liquid sounds $/ \mathrm{f} /$ and $/ \mathrm{l} /$ sometimes alternate both in coda $($ pol $<$ por, carma $<$ calma) and onset positions (cora < cola 'tail', milá < mirar 'to watch') (13). Romero (1987:142) reports several cases of this kind (torara < toda la 'all the', tarega < talega 'moneybag', ingré < inglés 'English', arza < alzar 'to rise', derante < delante 'before', plimos < primos 'cousins', poltariyo < portalillo 'little gate', plecio $<$ precio 'price', talifa < tarifa 'tariff', eclibio < escribió he wrote', velde < verde 'green', comel < comer 'to eat'); he also indicates that the phoneme /1/ is sometimes elided in final position ( $e<e l$ 'the', mie < miel 'honey', arbo < árbol 'tree').

Lipski (1994a: 188-189) indicates that beginning in the 16th century the majority of the Afro-Peruvian texts he analyzed show cases of /l/ and / $/$ neutralization and confusion (moleno < moreno 'black', palese < parece 'it seems', aleglar < alegrar 'to delight', nostla < nuestra 'our', coltezano < cortesano 'courtier', hasel < hacer 'to do', melse < merced 'reward', poltal < portal 'gate'). Cuba's (2002:32) contemporary data align with the examples just presented (puelta < puerta 'door', El Calme $<$ El Carmen 'El Carmen', velde $<$ verde 'green'). Similar cases of variation are also common to several other Afro-Hispanic dialects in the Americas, as example (14) shows.

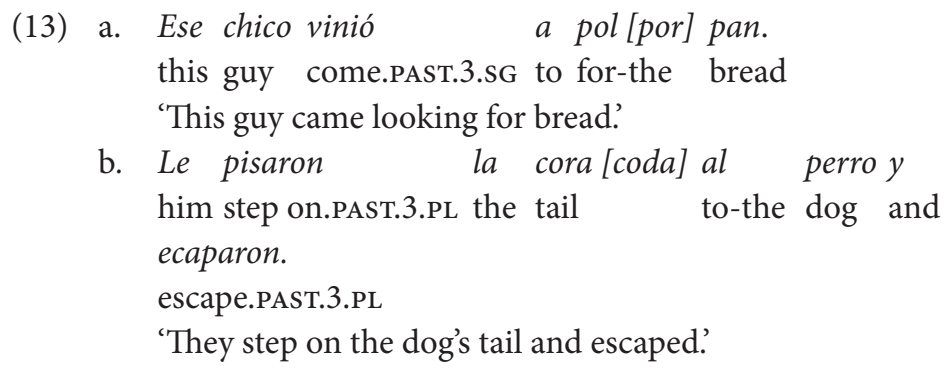


c. Carma, carma, [calma, calma] ya the dicho calm calm already to you AUX.PREs.1.sG said "itate tranquilo!".

be-you quiet

'Calm down, calm down, I've alredy told you "be quiet!'”

(14) a. Mier [miel] de abeja.

honey of bee

'Bee honey.'

b. Cravo [clavo]; probriema [problema]

nail problem

'Nail; problem'

c. Parma [palma]; vilgen [virgen]

(Afro-Panamanian Spanish; Lipski 1989:40)

'Palm;

virgin'

(Chocó Spanish; Ruiz-García 2009: 75-76)

In Romero's corpus, $/ 1 /, / \mathrm{s} /$, and $/ \mathrm{d} /$ are often confused. Such a phenomenon is quite common in colonial Afro-Hispanic texts; for example, it can be easily found in the corpus analyzed by Álvarez Nazario (1974) for Afro-Puerto Rican Spanish. However, in contrast with the Puerto Rican examples, in colonial Afro-Peruvian the assimilation of / $/$ to the following consonant is not common (atta < alta 'tall', amma < alma 'soul'). Romero indicates that the lack of such phenomena in the Peruvian corpus is probably due to the fact that the authors of these texts were more influenced by the Peninsular style of depicting black speech than by the Caribbean one. The author backs this hypothesis by highlighting that in Golden Age Spanish texts such processes were also lacking.

(V) Neutralization of $/ \mathrm{s} /$ and $/ r /$

My data (15), in line with Romero's, indicate that $/ \mathrm{r} /$ and $/ \mathrm{r} /$ distinction is sometimes lost (amará < amarrar 'tie up', pero < perro 'dog', sigaro < cigarro 'cigar', derame < derrame 'spillover', ariba < arriba 'above') (Romero 1987: 142). This case of neutralization is also commonly encountered in other Afro-Hispanic languages spoken in the Americas, as the examples in (16) illustrate.

(15) a. Este pero ladra siempre, toro [todo] el día ladra This dog bark.PRES.3.sG always all the day bark.PREs.3.sG el perro este. the dog this 'This dog is always barking, this dog barks all day long.'

b. El vaso de Juan lo puso ella ariba [arriba]. the glass of Juan it put.PAST.3.sg she above 'She put Juan's glass up there.' 
c. Eso es una bara [barra] de metal, es un tubo this be.PRES.3.sg a stick of metal be.PRES.3.sG a pipe de hierro.

of hiron

'This is a metal bar, it is an iron pipe.'

(16) a. Parra [para]; caru [carro].

For car

'For; car.' (Afro-Bolivian Spanish; Sessarego 2011a: 46)

b. Tera [tierra]; buru [burro] land donkey

'Land; donkey' (Afro-Puerto Rican Spanish; Álvarez-Nazario 1974: 165)

c. El perito [perrito]

the little-dog

'The little dog'

(Dominican Spanish; Willis \& Bradley 2008: 89)

d. Tonces agara [agarra]

then grab.PRES.3.sG

'Then he grabs'

(Dominican Spanish; Willis \& Bradley 2008:91)

(VI) /Cr/ onset consonant clusters

Traditional APS speakers tend to simplify onset consonant clusters of the type $/ \mathrm{Cr} /$ (17). This phenomenon has also been previously reported by Cuba (2002:28) (madina < madrina 'godmother', nosotos < nosotros 'we', poramas < programas 'programs') and appears to be in line with the aforementioned tendency leading to the creation of $\mathrm{CV}$ syllabic structures.

(17) a. Nosoto [nosotros] no queremo salí de Chincha, aquí we no want.PREs.1.PL leave of Chincha here es un paraíso.

be.PRES.3.sG a paradise

'We do not want to leave Chincha, this is a paradise.'

b. La gente potesta [protesta] porque les robaron la tierra the people protest.PRES.3.sG because to them steal.PAST.3.PL the land $y$ no les dieron nada.

and no to them give.PAst.3.PL nothing

'People protest because they stole their land and did not give anything to them.'

c. El contato [contracto] era algo para ayudá a los the contract be.PAST.3.sG something for help to the peones de acá.

peons of here

'The contract was something to help the local peons.' 
(VII) Conversion $/ f />\left[h^{w}\right]$ and pronunciation of $\langle h\rangle$

The phoneme /f/, when found in the onset position, especially word-initially, tends to be pronounced as $\left[\mathrm{h}^{w}\right]$; this phenomenon can be heard in words such as $h^{w}$ amilia < familia 'family' and $h^{w}$ eria < feria 'vacation' (cf. Cuba 2002:31). In some cases, the same sound may also be encountered in word-initial position for lexical items that are spelled with the grapheme $<\mathrm{h}>$ : $h^{w}$ umar $<$ humar 'to smoke', $h^{w}$ eder < heder 'to stink', while, as we know, in standard Spanish such a grapheme is phonetically mute (cf. Romero 1987:138) (18). This is a phenomenon that can be encountered in other Afro-Hispanic languages (19) and, more generally, in several Latin American and Peninsular Spanish rural varieties.

(18) a. La hwamilia [familia] Vallumbrosio es muy conocida acá. the family Vallumbrosio be.PREs.3.sG very known here 'The Vallumbrosio family is well-known here.'

b. La $h^{w}$ iesta [fiesta] de la santa no hay que perderla. the party of the saint no ExIs.PREs that miss-it 'We cannot miss the Saint celebration.'

c. Hwuimo [fuimos] todos para ver a la virgen. be.Pres.1.PL all for see to the virgin 'Everybody went to see the virgin.'

(19) a. Nosotros $h^{w}$ uimos [fuimos] al río. we go.PAST.1.PL to-the river

'We went to the river' （Chota Valley Spanish; Sessarego 2013c:50-51)

b. $H^{w}$ ruta [fruta]; $h^{w}$ lor [flor]. fruit flower 'Fruit; flower.' (Afro-Bolivian Spanish; Lipski 2008:72)

c. Ahwera [afuera]; $h^{w}$ uerza [fuerza] outside strenght 'Outside; strength'

(Afro-Puertorican Spanish; Álvarez-Nazario 1974: 181)

\section{(VIII) Yeísmo and /j/ weakening}

Unlike Highland Peruvian Spanish, where the distinction between the palatal sound $/ K /$, written as $<\mathrm{ll}>$ and the phoneme $/ \mathrm{j} /$, written as $\langle\mathrm{y}\rangle$ is found, APS presents the typical features of coastal Peruvian dialects, where such a distinction has been lost, and the only sound encountered is $/ \mathrm{j} /$ : caye < calle 'street'; yama < llama 'he calls'. Romero (1987: 125) indicates that much variation is found in his texts, so that both $<\mathrm{ll}>$ and $<\mathrm{y}>$ are often found (llama 'he calls', criollito 'little Creole person', allá 'there', beya < bella 'pretty', oya $<$ olla 'pot', cabayero < caballero 'gentleman'). He ascribes this pattern to the fact that the colonial authors were probably generally biased toward writing these words with the proper 
Spanish spelling, even though they were pronounced differently by the slaves. In contemporary APS, it is also possible to hear words like gaina < gallina 'hen' and chiquío < chiquillo 'little boy', where the sound /j/ has been completely lost (20). Romero (1987: 126) also reports examples of this kind molenio < morenillo 'little black', mocía < morcilla 'blood sausage', mosquía < musiquilla 'little music'. Lipski (1994a: 188) indicates that even the Afro-Peruvian colonial texts proceeding from Cusco, a highland town where lleísmo has always been the norm, clearly show that the speech used by bozales slaves was yeista. In this respect, APS is also in line with the majority of the Afro-Hispanic dialects, which, excluding a few exceptions (e.g. Chota Valley Spanish, cf. Sessarego 2013c: 65), are for the most part yeístas (21).
a. Elena, pasámelo
el martío [martillo].
Elena give.IMP.2.sG me it the hammer
'Elena, give me hammer.'

b. La canción "Me yaman caye" de Manu Chao me the song me call.PREs.3.PL street of Manu Chao to me gusta mucho.

like.3.sG much

'I like Manu Chao's song "Me llaman calle".

c. Hay que yamar [llamar] a señor del Zarandango pa que Have.PREs that call to man of the Zarandango for that abra.

open.PRES.3.SG

'We have to call the guy from Zarandango so that he will open.'

(21) a. Eyu [ellos]; caye [calle]

they street

'They; street'

(Afro-Bolivian Spanish; Sessarego 2011a:46)

b. Biyete [billete]

ticket

'Ticket'

c. Ga3ina [gallina]; a 3í [allí]

(Afro-Cuban Spanish; Lipski 2005: 154)

hen

there

'Hen; there'

(Chota Valley Spanish; Sessarego 2013c: 65).

(IX) Velarization of $/ n$ /

Word-final / $\mathrm{n} /$ is often velarized (son amigos < son amigos 'they are friends'; tan amable < tan amable 'so lovely') (22). Lipski (1994a) reports this phenomenon on several occasions for APS. However, final /n/ velarization is also often found in other Peruvian coastal dialects and in other Afro-Hispanic varieties (23). Romero (1987) also indicates cases of nasal palatalization [n] (ñiedo $<$ miedo 'fear', ñudo $<$ 
nudo 'knot', cañuto < canuto 'felt', demoño < demonio 'demon'), which, however, I was not able to find in my data; while Cuba reports cases in which stops have been nasalized by assimilation (donne < donde 'where', innorante < ingnorante ignorant'), and instances of vowel nasalization, where the nasal consonant has been completely lost ( $\tilde{u}$ yato < un llanto 'a crying', sããgru < santa cruz 'holy cross'). These last examples align perfectly with those encountered by Lipski (1994a: 202) and Romero (1987: 107) in colonial texts (lon branco < los blancos 'the white men', len gutará < les gustará 'you will like it', lon reguelva < lo revuelva 'turn it', yo son negra < yo soy negra 'I am black', nengla < negra 'black', ansía < hacía 'he used to do', manque < más que 'more than', dempués < después 'after', lon branco < los blancos 'the white men').

(22) a. Estos chicos soy [son] amigos desde hace mucho tiempo. these guys be.PRES.3.PL friends from ago much time 'These guys have been friends for a long time.'

b. Lo que dijo Sarlino me pareció tay [tan] amable. it that say.PAST.3.sg Sarli no to me seem.PAST.1.sG so lovely 'What Sarli said did not seem to me so lovely'.

c. Es una canción [canción] de Vallumbroso. be.PRES.3.sG a song of Vallumbroso 'That is a Vallumbroso's song.'

(23) a. Sin [sin] eso without this 'Without this'

b. Muy biey [bien] (Barvolento Spanish; Megenney 1999: 82) very well 'Very well' (Afro-Panamanian Spanish; Lipski 1989:43)

c. Biey [bien] hecho. well done 'Well done' (Afro-Panamanian Spanish; Lipski 1989:43)

d. Sin [sin] saber without knowing 'Without knowing'

(X) Weakening and deletion of $/ \mathrm{b} /, / \mathrm{d} /, / \mathrm{g} /$

My corpus shows several instances of intervocalic /b/, /d/, /g/ weakening and deletion (cantaa < cantaba 'he used to sing', naa < nada 'nothing', mujerieo < mujeriego 'womanizer') (24), in line with the cases encountered by Romero (1987:141) (tamién < también 'too', taurete < taburete 'stool', mae < madre 'mother', parino < padrino 'godfather'). These phenomena for contemporary APS have been extensively described by Cuba (2002:26-28) (25), while similar phonological processes 
have also been reported for a variety of Afro-Hispanic languages in the Americas, as example (26) confirms.

(24) a. Todo eso no me impota naa [nada].

all this no to me matter.PREs.3.sG nothing

'I do not care about all of this.'

b. Mi tío cantaa [cantaba] y mi padre tocaba.

my uncle sing.PAST.3.sG and my father play.PAST.3.sG

'My uncle used to sing and my father used to play.'

c. Le dicen que es mujerieo [mujeriego] porque to her say.PRES.3.PL that be.PRES.3.sG womanizer because ni se sabe cuánto hijo tiene. nor REFL know.PRES.3.sG how many son have.PRES.3.SG

'They tell him that he is a womanizer because nobody knows how many children he has.'

(25) a. Me lo roaron [robaron].

to me it steal.PAST.3.PL

'They stole it from me.'

(Cuba 2002:26)

b. Pa' oce [pa'doce] días.

for twelve days

'For twelve days.'

(Cuba 2002:27)

c. Seundo [Segundo].

second

'Second'.

(Cuba 2002:28)

(26) a. Caeza [cabeza]; pare [padre]

head father

'Head; father' (Eastern Afro-Venezuelan Spanish; Megenney 1999: 84)

b. Mandau [mandado]

sent

'Sent'

(Afro-Bolivian Spanish; Sessarego 2011a: 117)

c. Bolíare [bolivares]

bolivarians

'Bolivarians'

(Barlovento Spanish; Megenney 1999: 84)

\subsubsection{Intonation patterns}

Afro-Peruvian Spanish suprasegmental features appear to parallel those encountered in other Afro-Hispanic dialects. This variety shows multiple early-aligned peaks and minimal downstep across non-exclamatory non-focused declaratives. This is quite divergent from the pattern encountered in other Spanish dialects; 


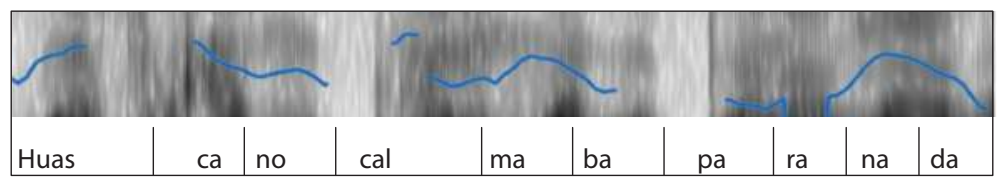

'The whip did not stop at all.'

Figure 3.1 Multiple early-aligned peaks and minimal downstep across non-exclamatory non-focused declaratives

while it has often been detected in Afro-Hispanic varieties across the Americas, such as black Dominican Spanish (Willis 2003), Palenquero (Hualde \& Schwegler 2008; Correa 2012), and the black dialects of Mexico, Venezuela, Bolivia, Colombia, Ecuador, Panama and Cuba (Lipski 2007b).

\subsection{Afro-Peruvian Spanish morpho-syntax}

Traditional APS shows a variety of morpho-syntactic features that deviate from standard Spanish and are commonly encountered in other Afro-Hispanic dialects and second-language varieties of Spanish. The following sections will provide an overview of such grammatical patterns.

\subsubsection{Noun Phrase}

\section{(I) Number agreement}

A common feature encountered across a variety of Afro-Hispanic languages and in APS is the lack of number agreement across the Noun Phrase. In fact, unlike Spanish, which marks the feature number redundantly on all the nominal elements, traditional APS conveys plurality only on determiners, thus not showing plural markers on nouns and adjectives. In particular, APS presents striking similarities with Afro-Bolivian Spanish and Chota Valley Spanish (Sessarego 2013c, 2014a), where number is expressed exactly in the same way. APS Noun Phrases can express plurality by recurring to plural -s morphology on definite and indefinite articles (27a-b), possessives (27c) and demonstratives (27d), or by being headed by quantifiers (27e) and numerals (27f), which can convey plurality inherently, without recurring to morphological markers (cf. Baptista \& Guéron 2007).

(27) a. Los trabajador internacional. the.PL worker.sG international.sG 'The international workers.' 
b. Unos trabajador internacional. some.PL worker.sG international.sG

'Some international workers.'

c. Mis trabajador internacional. my.PL worker.sG international.sG 'My international workers.'

d. Esos trabajador internacional. this.PL worker.sG international.sG 'These international workers.'

e. Mucho trabajador internacional. many worker.sG international.sG 'Many international workers.'

f. Cinco trabajador internacional. five worker.sG international.sG 'Five international workers.'

Due to contact with standard Spanish, it was possible to find much variation in the speech of the informants interviewed; thus forms deprived of plural marking would alternate with those presenting such an inflection, as in (28).

(28) Cuando ibamos a las fiesta, algunos amigos compraban when go.PAST.1.PL to the.PL party.SG some.PL friend.PL buy.PAST.3.PL muchas bebidas, otros ponían el dinero para las many.PL drink.PL other.PL put.PAST.3.PL the.sG money.sG for the.PL comida $y$ algunos armaban las cosa para tocar las food.sG and some.PL set.PAST.3.PL the.PL thing.sG for play the.PL canción tradicional. song.sG traditional.sG

'When we went to the parties, certain friends bought many drinks, others put in the money for the food and others set things so that they could play the traditional songs.'

Non-redundant plural marking across the Noun Phrase was also identified by Cuba (2002:37), who offered a variety of naturalistic examples (29).

(29) a. Tre día.

Three day.sG

'Three days.'

b. Ella tiene doce maceta grande. she have.PRES.3.sG twelve pot.sG big.sG 'She has twelve big pots.' 
c. Santa María tiene sus ola como un río.

Saint.sG Mary have.PREs.3.sg her.sg wave.sG like a.sG river.sG 'St. Mary has waves like a river.'

Lipski (1994a:209) indicates that the lack of plural marking on nouns was highly common in the colonial texts he analyzed. He points out that this phenomenon is typical of L2 Spanish learners and that it may also be due to the African substrates. In fact, in several African languages, nouns do not carry plural inflection. Rather, the semantic notion of plurality can usually be inferred from the context or is expressed by a particle, which can either appear prenominally (e.g. in Yoruba) or postnominally (e.g. in Ewe). In Chapter 4, I will further elaborate on the nature of these constructions to suggest that they appear to be the result of advanced, conventionalized L2 strategies, which might not necessarily have been significantly affected by the L1s spoken by the learners. Instances of number agreement mismatches are a common feature of all Afro-Hispanic dialects and, more generally, of all contact varieties, where inflectional morphology tends to be lost. Some Afro-Hispanic examples are reported in (30).

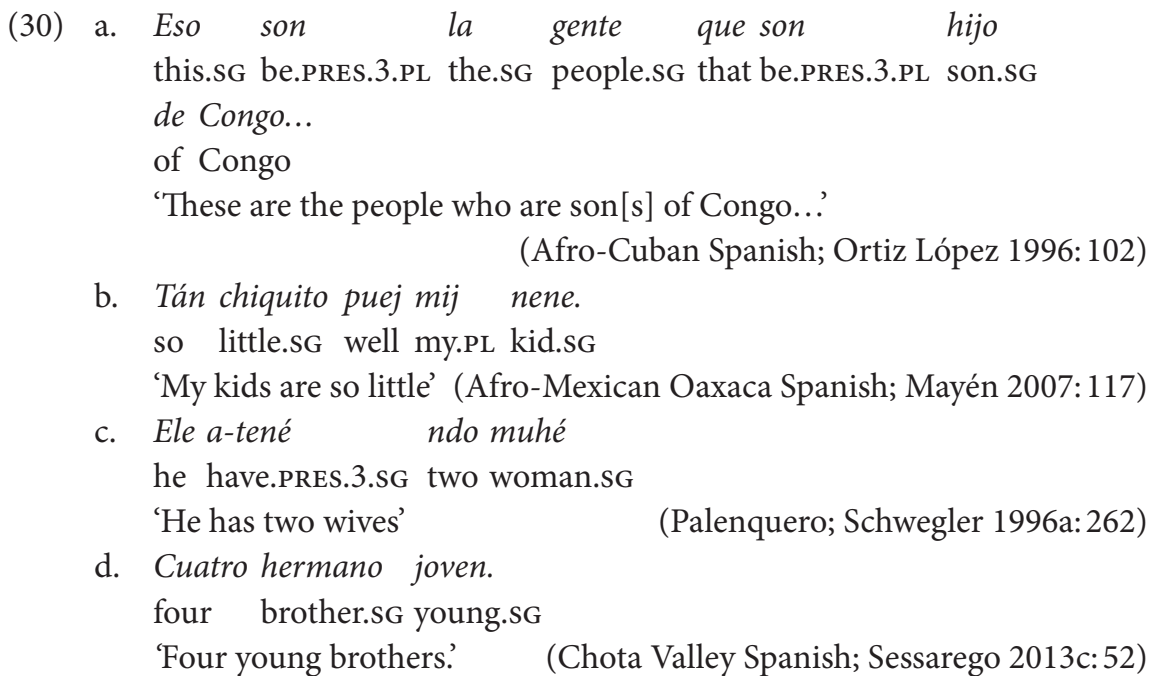

(II) Gender agreement

Another phenomenon commonly encountered in Afro-Peruvian Spanish is variable gender agreement. After carrying out grammatical judgments on a sample of twelve informants, three different gender agreement patterns were attested (Groups A, B, C) (see Gutiérrez-Rexach \& Sessarego 2014). Group A (2 elderly speakers) had grammatical intuitions that can be exemplified in (31), where gender agreement affects all the categories but strong quantifiers. 
(31) a. Todo la sopa rica.

all.m the.F soup.F tasty.F

'All the tasty soup.'

b. Mucha/esta/una sopa rica.

much.F/this.F/a.F soup.F tasty.F

'Much/this/a tasty soup.'

Group B (2 elderly speakers) presented the agreement configuration instantiated by example (32), where the only non-agreeing category is post-nominal adjectives.

(32) a. Toda la sopa rico.

all.F the.F soup.F tasty.M

'All the tasty soup.'

b. Mucha/esta/una sopa rico.

much.F/this.F/a.F soup.F tasty.M

'Much/this/a tasty soup.'

Finally, Group C (the 8 remaining speakers) presented the fully generalized pattern from standard Spanish (33).

(33) a. Toda la sopa rica.

all.F the.F soup.F tasty.F

'All the tasty soup.'

b. Mucha/esta/una sopa rica.

much.F/this.F/a.F soup.F tasty.F

'Much/this/a tasty soup.'

The results from grammaticality judgments were also compared to data extracted from sociolinguistic interviews. The comparison between these two different sources clearly indicated that several informants who claimed to use gender agreement for certain grammatical categories during the questionnaires were found lacking it in the sociolinguistic recordings. To obtain a more detailed picture, 2,445 tokens from the sociolinguistic interviews were extracted and coded according to the factor groups 'grammatical category' and 'generation'. Thus the factor group 'grammatical category' consisted of the following individual factors: demonstratives/definite articles, weak quantifiers, pronominal adjectives, strong quantifiers, and postnominal adjectives. The factor group 'generation' included the three following age groups: $21-50,51-80,81+$. Given the lack of variation for certain factors, the first run provided knock-outs (cf. Tagliamonte 2006: 152153). For this reason, tokens had to be recoded and several grammatical categories were collapsed, as well as the generations $21-50$ and 51-80. Such a recodification allowed Varbrul to run the data, providing the results presented in Table 3.1. 
Table 3.1 Cross-generational variable rule analysis of the contribution of internal factors to the probability of lack of gender agreement in Afro-Peruvian Spanish (Total = 2455; Log likelihood $=-210.896$; Total Chi-square $=5.2353$; Chi-square/cell $=0.8725$; Significance $=0.000 ;$ Input $=0.007)$

\begin{tabular}{lcccc}
\hline & Factor weight & \% Lack agreement & N & \% Data \\
\hline GRAMMATICAL CATEGORY & .94 & 11 & 261 & 11 \\
Post-Nom. Adj. & .92 & 9 & 249 & 10 \\
Strong Q. & .34 & 1 & 1945 & 79 \\
Other Ds. & Range & & & \\
& 60 & & & \\
GENERATION & .76 & 6 & 781 & 32 \\
$81+$ & .37 & 1 & & 68 \\
$21-80$ & Range & & & \\
\hline
\end{tabular}

As can be observed, post-nominal adjectives and strong quantifiers in APS strongly disfavor concord (factor weights .94 and .92), while the other determiners favor it (factor weight .34). The factor group 'generation' is also significant, with generation $81+$ favoring lack of gender agreement (factor weight .76) and generations $21-50$ and 51-80 favoring agreement (factor weight .37). These results show that little variation occurs among the speakers younger than $81+$, thus indicating that lack of gender agreement is in APS a phenomenon primarily concerned with older informants, not very relevant for the rest of the speech community and in all likelihood destined to disappear within the next twenty years or so. Figure 3.2 summarizes the results obtained for the evolution of gender agreement across the nominal categories in APS.

As can be noted, even though the tokens had to be recoded to obtain significant results with Varbrul, the evolutionary agreement trend of APS appears to follow the hierarchical steps depicted in (34), which parallels those found in previous studies for Afro-Bolivian Spanish and Chota Valley Spanish (cf. Sessarego \& Gutiérrez-Rexach 2011, 2012; Gutiérrez-Rexach \& Sessarego 2014).

(34) Demonstratives/Definite Articles > Weak Quantifiers >

Prenominal Adjectives $>$ Strong Quantifiers $>$ Postnominal Adjectives.

The examples in (35)-(38) provide a sample of naturalistic data extracted from the sociolinguistic interviews presenting instances of variable gender agreement. It is found on prenominal and postnominal adjectives (35), indefinite articles (36), and weak and strong quantifiers (37). On the other hand, definite articles 
Afro-Peruvian Spanish

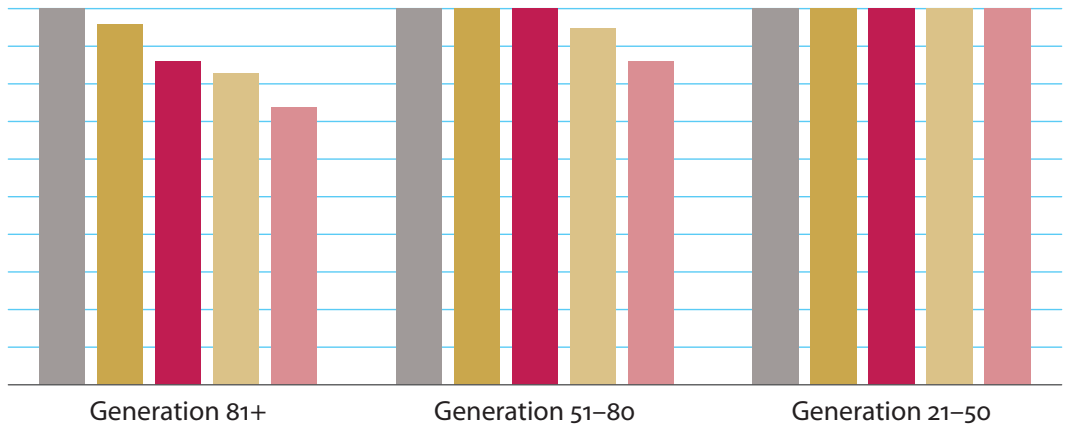

Demonstratives/ Definite Articles

Weak Quantifiers

Prenominal Adjectives

\section{Strong Quantifiers}

Postnominal Adjectives

Figure 3.2 Gender agreement evolution in APS

and demonstratives appear to always agree with the noun they precede (38). As can be observed, all the cases of lack of gender agreement correspond to the appearance of the default masculine forms, thus no cases of mismatch between a masculine noun and a feminine adjective or determiner were found.

(35) a. Esa gente peruano, esa gente peruano de los this.F people.F Peruvian.m this.F people.F Peruvian.m of the.m Andes son diferente.

Andes be.PrEs.3.PL different

'These Peruvian people, these Peruvian people from the Andes are different.'

b. Una muchacha borracho no me gusta.

a.F girl.F drunk.M no me like.PREs.3.sG

'I do not like drunk ladies.'

c. Buen persona no ha venío. good.m person.F no AUX.PRES come 'The good person did not come.'

d. Se trata de una cuestión problemático. REFL matter.PRES.3.SG of a.F issue.F problematic.M 'It is a matter of a problematic issue.'

(36) a. Un hoja se ha caío del álbol. a.m leaf.F REFL AUX.PRES felt of the.m tree.m 'A leaf fell from the tree' 
b. Un bandera de un nación importante.

a.M flag.F of an.m nation.F important

'A flag of an important nation.'

c.. Fue un semana sin descanso.

be.PAST.3.sG a.M week.F without rest.M

'It was a week without rest.'

d. Dició que un vez vinió con mi pare.

say.PAST.3.sG that a.M time.F come.PAST.3.sG with my father.M 'He said that one time he came with my father.'

(37) a. Mucho persona ya se han ido.

many.M person.F already REFL AUX.PRES.3.PL went

'Many people have already left.'

b. Todo la gente que conozco no quiere al

all.m the.F people.F that know.PREs.1.sG no want to the.m gobierno.

government.M

'All the people I know do not like the government.'

c. Algún típico comidason papa con arroz. some.m typical.m food.F be.PAST.3.PL potato.m with rice.m 'Some typical foods are potatoes with rice.'

d. Poco hambre tiene la huawa. little.m hunger.F have.PREs.3.sG the.F kid.F 'The kid is not very hungry'.

(38) a. La escuela ha ayudado mucho a la gente the.F school.F AUS.PRES.3.sG helped much to the people.F de acá.

from here

'The school has helped the local people a lot.'

b. La amiga de María cocina muy rico. the.F friend.F of Mary cook.PREs.3.sG very well 'Maria's friend cooks very well.'

c. ¿Esas mujé que habían preparao?

These.F woman.F what AUX.PAST.3.PL prepared 'What did these women prepare?'

d. Esta música yo ya la había escuchao. this.F music.F I already it.F AUX.PAST.1.sG listened 'I had already listened to this music.'

Variability in gender agreement is a feature frequently reported for the speech of black communities in the Americas; it is also commonly found in second 
language varieties of Spanish. The examples in (39) present some cases encountered in other Afro-Hispanic vernaculars.

(39) a. Mugué malo.

woman.F bad.M

'Bad woman.' (Afro-Puerto Rican Spanish; Álvarez Nazario 1974: 189)

b. Quieren cosa ligero.

want.PREs.3.PL thing.F light.m

'They want light things.'

(Chocó Ruiz-García 2009: 77)

c. En este semana.

in this.m week.F

'This week.'

(Afro-Bolivian Spanish; Lipski 2008: 86)

d. Todo esa gente vieja.

all.m this.F people.F old.F

'All these old people’. ～(Afro-Cuban Spanish; Ortiz López 1996: 101)

\section{(III) Bare nouns}

In line with other Afro-Hispanic dialects and unlike standard Spanish, APS presents bare nouns in both subject and object positions, where they may take on either a generic or specific reading depending on the context in which they appear (cf. Baptista \& Guéron 2007).

(40) a. ¡Gente de acá ya ha dicho 'que no’!

people of here already AUX.PREs.3.sG said that no

'People from here have already said 'no'?

b. Venía mayordomo y mandaba las cosa.

come.PAST.3.PL overseer and order.PAST.3.SG the thing

'The overseer used to come and give orders.'

c. Madre quere jugá con huawa.

mother want.PRES.3.sG play with kid

'The mother wants to play with the kid / Mothers want to play with kids'.

d. Mujé trabajaba también, más que hombre.

woman work.PAST.3.sG too more than man

'Women worked too, more than men.'

e. Mi tía prepara plato tradicional.

my aunt prepare.PRES.3.sG dish traditional

'My aunt prepares a traditional dish / My aunt prepares traditional dishes.'

Instances of APS bare nouns have also been spotted by Lipski (1994a:207-209), who reported the following examples (41). 
(41)
a. Niño no responde nara.
baby no answer.PRES.3.sG nothing
'The child does not answer anything.'
b. Nega Casilda no moleta, amita.
black Casilda no bother.PREs.3.sG madam
'The black woman Casilda does not bother anybody, madam.'
c. Neglo será presilente.
black be.FUT.3.sg president
'A black man will be president.
d. Ella [me ha] aydao matá cabrita.
she me AUX.PRES.3.sG helped kill little goat
'She helped me kill the little goat.'

Additional examples of bare nouns in other Afro-Hispanic dialects are presented in (42).
a. Lorenzo come
Lorenzo eat.PRES.3.sG orange
b. Jilicata tiene
c. Yo trabajo mina.
I work.PRES.3.sg mine
'I work the mine.' naranja.

'Lorenzo eats oranges.' (Chota Valley Spanish; Sessarego 2013c: 54) que ehtá masiendo. overseer have.PRES.3.sG that be.PRES.3.sG weeding 'The overseer has to be weeding.'(Afro-Bolivian Spanish; Lipski 2008: 85)

(Chocó Spanish; Ruiz-García 2009:45)

\subsubsection{Verb Phrase}

\section{(I) Regularization of irregular verb forms}

Across the Afro-Peruvian verbal system it is possible to find cases of regularization that tend to homogenize the conjugations, thus eliminating some of the irregularities found in standard Spanish. This phenomenon is quite noticeable with past participles (43), with irregular verbs presenting stem-vowel changes (44), and with some imperfect past forms that are used in APS with the - $b a$ ending while in standard Spanish they require the -ía morpheme (45). Similar cases of overgeneralization are typical of Spanish interlanguages and have also been reported for other Afro-Hispanic dialects such as Afro-Bolivian Spanish (46) (see Sessarego 2011a: 53).

$$
\begin{aligned}
& \text { a. Dizque se ha muríu [muerto]. } \\
& \text { apparently REFL Aux.Pres.3.sg dead } \\
& \text { 'They say he died.' }
\end{aligned}
$$


b. El Zarandango ha abríu [abierto] más tarde hoy. the Zarandango AUX.PRES.3.sG opened more late today 'The Zarandango opened later today'.

(44)
a. Él dició [dijo] que había
un fantasma.

he say.PAST.3.sG that AUX.PAST.3.sG a gost

'He said that there was a ghost.'

b. Ese duende vinió [vino] al campo donde estaba

this elf come.PAST.3.sg to the field where be.PAST.3.sG

la bruja.

the witch

'This elf came to the field where the witch was.'

(45) a. El muchacho ese abriba [abría] toda las lata.

the guy this open.PAst.3.sG all the can

'This guy opened all the cans.'

b. Te hablo del hombre que dormiba [dormía] bajo

you talk.PRES.1.sG of the man that sleep.PAST.3.sG under

el árbol.

the tree

'I am talking about the man that was sleeping under the tree.'

(46) a. Pulga mi ha víu [visto].

Pulga me Aux.PrEs.3.sG seen

'Pulga saw me.'

b. Pedro hició [hizo] todu.

Pedro do.PAst.3.sG all

'Pedro did everything.'

c. Lu joven saliba [salían] di fiesta.

the young go-out.PAST.3.sG of party

'The young people used to go out to party'.

(II) Archaic forms

Cuba (2002:34-35) pointed out the presence of some archaic forms in the verbal system of this Afro-Hispanic dialect. In particular, she reported high frequencies of use for the past subjunctive marker -se, which in contemporary colloquial Spanish is not very common and has been for the most part substituted by the morpheme -ra (47).

(47) Yo hubiese [hubiera] sembrado dos parcelas.

I have.PAST.SUBJ.1.sG planted two fields

'I would have planted two fields.' 
She also found verbal conjugations for the verb ver 'to see' that have been completely lost in contemporary Spanish, but were commonly used centuries ago (48).

(48) a. Yo lo vide [vi].

I him see.PAST.1.sG

'I saw him.'

b. Él también lo vido [vio].

he too him see.PAST.3.sG

'He saw him too'

(III) Ser and estar

The verb ser is sometimes used where estar would be employed in standard Spanish; in some occasions copulas are omitted.

(49) a. Felipe ya es [está] cansado.

Felipe already be.PRES.3.sG tired

'Felipe is already tired.'

b. Mi marido es [está] a Trujillo.

my musband be.Pres.3.sG at Trujillo

'My husband is in Trujillo'

c. Eyos (son) mayó.

they be.PREs.3.PL old

'They are old.'

These findings are in line with the data reported by Cuba (2002:34) (50).

(50) Es grande, sí, pero es más triste... más desolado... be.PRES.3.sG big yes but be.PRES.3.sG more sad more remoted porque... por ejemplo, acá hay una casa ¿no? Más arriba, por because for example here ExIS.PREs a house no more above for 'onde Almeida hay otra casa. No son [están] juntas, where Almeida EXIS.PREs other house no be.PRES.3.PL together son [están] distanciadas las casas.

be.PRES.3.PL apart the houses

'It is big, yes, but it is more sad ... more desolate, because, for example, here there is a house, right? Over there, where Almeida lives there is another house. The houses are not together, they are far apart.'

Similar cases have been widely encountered in L2 Spanish varieties and in several Afro-Hispanic dialects across the Americas (51). 
(51) a. Yo soy mucho enjuermo.

I be.PREs.1.sG very sick

'I am very sick.'

(Afo-Bolivian Spanish; Sessarego 2011a:54)

b. El 23 de diciembre eran la gente [...] por la calle.

el 23 of december be.PAST.3.PL the people for the street

'On December 23rd people were along the street.'

(Afro-Cuban Spanish; Ortiz-López 1996: 81)

c. Tú [eres] comunita.

you be.PRES.2.sG comunist

'You are a communist.' （Afro-Panamanian Spanish; Lipski 1989:26)

(IV) Haber 'to exist' / tener 'to have'

While in standard Spanish the verb haber expresses existence and tener conveys possession, in APS (52), as in other Afro-Hispanic dialects (53), their uses may overlap. In my corpus, tener may be found in existential constructions, while haber can be preceded by ' $n o$ ' to express negation of possession.

(52) a. Tiene una maestra en la escuela que cuida a todos EXIS.PRES a teacher in the school that care.PREs.3.sG to all los estudiante.

the students

'There is one teacher in the school who takes care of all the students.'

b. Ahí tenía ingenio de azúcar.

there EXIs.PAST refinery of sugar

'There was a sugar refinery there.'

c. Esa gente no habia nada de dinero.

this people no have.PrEs.3.sG nothing de money

'These people did not have money at all.'

d. Ella no había miedo.

she no have.Pres.3.sg fear

'She is not scared.'

(53) a. Los mayor no había esa costumbre.

the old no have.PAst.3.PL this habit

'Old people did not have this habit.'

(Chota Valley Spanish; Lipski 2009: 105)

b. Tenía mucho bicho antes.

EXIS.PAST many insect before

'There were many insects before.'

(Chota Valley Spanish; Sessarego 2013c:59) 
c. Yo nu hay cajué.

I no have.PRES.3.sG coffe 'I do not have coffee.'

(Afro-Bolivian Spanish; Lipski 2008: 136)

d. Tiene gallina en la casa.

EXIS.PRES chicken in the house

'There are chickens in the house.'

(Afro-Bolivian Spanish; Sessarego 2011a: 54)

\section{(V) Reflexive se}

Oftentimes APS speakers do not use reflexive pronouns in constructions in which their use is compulsory in standard Spanish (54). This phenomenon, as is wellknown, is common to many Spanish interlanguages, and for this reason it is addressed by several advanced Spanish grammar textbooks (cf. King \& Suñer 2007). It is also frequent in a variety of Afro-Hispanic dialects across the Americas (55).

a. Ella [se] llama Juana.
she REFL call.PRES.3.sG Juana

'Her name is Juana.'

b. Los joven de aquí [se] están mudando a Lima the young of here REFL be.PRES.3.PL moving to Lima 'Young people from here are moving to Lima.'

c. Aldo [se] quedaba en el campo a tabajá. Aldo REFL stay.PAST.3.sg in the field to work 'Aldo used to stay in the field to work.'

(55) a. Eyus [se] llamaban Sarvo Sarvito they REFL call.PAST.3.PL Sarvo Sarvito 'They were called Sarvo Sarvito.'

(Afro-Bolivian Spanish; Sessarego 2011a:96)

b. Si no venía aquíal pueblo y taba bailar if no come.PAST.1.sG here to the village and be.PAST.1.sG dance [me] quedaba bailando arriba. REFL stay.PAST.1.sG dancing above 'If I did not come here to the village and I was dancing I would have danced there.' (Chocó Spanish; Ruiz-García 2009: 83)

c. Pa tú tambié [te] divertí for you too REFL enjoy 'So that you will also enjoy'.

(Afro-Puertorican Spanish; Álvarez Nazario 1974: 195) 


\subsubsection{Prepositional Phrase}

(I) Pleonastic prepositions de and a

Lipski (1994a:207-208) indicates that the prepositions lacking semantic import are those that tend to be omitted the most in the Afro-Peruvian bozal texts he analyzed. In particular, he highlighted the frequent omission of $a$ 'to', which in standard Spanish marks the indirect object and the personal direct object, as well as the preposition de 'of', which has multiple functions in the standard variety (e.g. it indicates possessor, theme, agent, etc. cf. Sessarego 2014a:Ch. 6). Lipski (1994a:207-208) and Cuba (2002:36) provide a list of examples (56) that are in line with some of the cases I found in my corpus (57).

(56) a. Salí [a] las ocho, dempué...

go-out.PAST.1.sG at the eight after

'I went out at eight, after ...'

(Lipski 1994a:207)

b. Bucá rebajo [de] la cama.

look under of the bed

'Looking under the bed.'

c. Cuando yo ta la congreso, yo neglo, yo va [a] dicí.

(Lipski 1994a:207)

when I be.PREs.3.sG the congress I black I go to say

'When I am in the congress, I am black, I will say.' (Lipski 1994a:208)

d. Ella ayudao [a] matá cabrita.

she helped to kill little goat

'She has helped kill the little goat.'

(Lipski 1994a:208)

e. Pare [de] familia.

father of family

'Family man.'

(Cuba 2002:36)

(57) a. Hay que ver [de] dónde son.

EXIs that see of where be.PREs.3.PL

'We must see from where they are.'

b. Sácalo [de] ahí.

remove.IMP.2.sG it of there

'Take it out from there.'

c. Nosotros vamos [a] trabajá mañana también.

we go.PREs.1.PL to work tomorrow too

'We will work tomorrow too.'

d. Vino [a] comer con nosotros.

come.PAST.3.sG to eat with us

'He came to eat with us.' 
Moreover, in my fieldwork recordings, I encountered several cases where the preposition $a$ 'to' is used with a locative function, where standard Spanish would employ en 'in' (58).

(58) a. Ana trabaja a [en] la oficina de su tío.

Ana work.PREs.3.sG at the office of her uncle

'Ana works in her uncle's office.'

b. Eyu estudiaron a [en] la escuela profesional. they study.PAST.3.PL at the school profesional 'They studied in the professional school.'

c. Estaba a [en] Lima luego ha vuelto.

be.PAST.3.sg at Lima after AUX.PRES.3.sG came back

'He was in Lima then he came back.'

d. Vive a [en] Lima con Aldo.

live.PRES.3.sG at Lima with Aldo

'She lives in Lima with Aldo.'

This locative function of the preposition $a$ has also been reported for Afro-Bolivian Spanish and Chota Valley Spanish (59).
a. Mi novio vive
a [en] Guayaquil.
my boyfriend live.PREs.3.sG at Guayaquil
'My boyfriend lives in Guayaquil.'

(Chota Valley Spanish; Sessarego 2013c: 61)

b. Estoy trabajando a [en] otro campo.

be.PRES.1.sG working at other field

'I am working in another field.'

c. Juan nació a [en] La Paz.

Juan born.PAsT.3.sG at La Paz

'Juan was born in La Paz.' (Afro-Bolivian Spanish; Sessarego 2011a:55)

d. Mi hijo vive a [en] Mururata.

my son live.PREs.3.sg at Mururata

'My son lives in La Paz.' （Afro-Bolivian Spanish; Sessarego 2011a:55)

(II) Con

The preposition con 'with' often substitutes the standard Spanish preposition de 'of' as well as the conjunction $y$ 'and' (60). Parallel phenomena have been reported in other Afro-Hispanic languages; in particular, Afro-Bolivian Spanish and Chota Valley Spanish appear to behave identically in this respect (61). 
(60) a. Persona con [de] corazón ya no hay. person with heart already no exis 'There are no generous people anymore.'

b. La bailarina con [de] pierna flaca fue el alma the dancer with leg skinny be.PAST.3.sG the soul de la $h^{w}$ iesta. of the party 'The skinny-legged dancer was the life of the party'.

c. Pisco con [y] huevo pa hacé el trago. Pisco with egg for make the drink 'Pisco and egg to prepare the drink.'

d. Yo con $[y]$ ella compramo jruta en el mercao. I with she buy.PAST.1.PL fruit in the market 'She and I bought fruit at the market.'

(61) a. Hombre con [de] esta edad no tiene que trabajá. man with this age no have.PREs.3.sG to work 'A man that old should not work.'

(Chota Valley Spanish; Sessarego 2013c: 60)

b. Wawa cun [de] esta edad pesa 20 kilo. kid with this age weight.PREs.3.sg 20 kilo 'A kid of this age weighs 20 kilos.'

(Afro-Bolivian Spanish; Sessarego 2011a:56)

c. Yo con $[y]$ él acabó de limpiá.

I with he finish.PAST.3.sG of clean

'He and I finished cleaning.' (Afro-Cuban Spanish; Ortiz López 1996: 90)

d. Yo con $[y]$ él fuimos al mercado.

I with he go.PAST.3.sG to the market 'He and I went to the market.'

(Chota Valley Spanish; Sessarego 2013c: 80)

\subsubsection{Phrase-level constructions}

(I) Non-emphatic non-contrastive subject pronouns

The difference between an overt subject and pro in a pro-drop language like standard Spanish is the presence of a [+topic shift] feature in the former which would be absent in the latter. Such a distinction does not exist in non-pro-drop languages such as English, where all subject pronouns must be spelled out (Grimshaw \& Samek-Lodovici 1998). APS, in line with many other Afro-Hispanic languages and Caribbean Spanish, appears to show a hybrid system, where overt subjects 
deprived of such a [+topic shift] feature are used redundantly, without signaling either emphasis or contrast, as in example (62).
(62) Mauricio fue
también. Él se
tomó
una botella
Mauricio be.PAST.3.sg too
he REFL drink.PAST.3.sg a bottle
de cerveza y después él se fue de fiesta.
of beer and after he REFL go.PAST.3.sG of party
'Mauricio went too. He drank a bottle of beer and afterwards he left to have fun.'

The use of non-emphatic, non-contrastive overt subjects, sometimes co-occurring with unconjugated verb forms, is found in a variety of Afro-Hispanic contact varieties (63).

a. Yo tando muy pequeña yo conocí a una señora.

I being very young I meet.PAST.1.sG to a woman 'When I was young I met a woman.'

(Barlovento Spanish; Megenney 1999: 117)

b. Claro yo como fue chico yo no acorda obviously I since be.PAST.3sg child I no remember.PREs.3.sG vela candle

'Obviously since I was a child I do not remember the candles'.

(Afro-Bolivian Spanish; Lipski 2008: 101)

c. Y yo ya me salí con eso porque yo taba and I already REFL leave.PAST.1.sG with it because I be.PAST.1.SG onde mi mamá y yo me salí con él de la casa. where my mother and I REFL leave.PAST.1.sG with he of the house 'And I left because I was where my mother was staying and I left the house with him.

(Chocó Spanish; Ruiz-García 2009:88-89)

In some cases, these features have been analyzed as the remaining traces of a previous creole stage, elements showing a genetic link between these Afro-Hispanic dialects, Afro-Brazilian Portuguese, creole varieties, and certain Western African languages (Perl 1998:7). For example, Perl indicates that a key feature commonly encountered in these languages is "a remarkable increase in the use of non-emphatic subject pronouns" (1998:6), probably related to the parallel impoverishment of inflectional verbal morphology. Megenney, who is of a similar opinion, suggests that the high rate of overt pronouns in Afro-Venezuelan Spanish may be linked to a previous creole phase, since "the constant presence of personal pronouns is one of the typical features found in creole languages, and in 
Colombian Palenquero these pronouns are used categorically" (1999: 117). ${ }^{9}$ We will return on this topic in Chapter 4, where I will show that these features commonly found in Afro-Hispanic languages should not necessarily be analyzed as the traces of a previous creole stage (see also Sessarego 2012).

\section{(II) Subject-verb agreement}

In line with the rest of the Afro-Hispanic varieties of the Americas (64), APS shows variable subject-verb agreement (65). In fact, third person singular forms may appear as default forms, especially in the speech of the eldest informants; also Cuba (2002:38) reports an instance of this phenomenon (66).

(64) a. Ellos dijo [dijeron] que iba [iban] al campo. they say.PAST.3.sG that go.PAST.3.sG to the field 'They said that they would go to the field.'

(Chota Valley Spanish; Sessarego 2013c: 76).

b. Tú jabla [hablas] y no conoce [conoces].

you speak.3.sg and no know.3.sG

'You speak and you do not know.' (Afro-Cuban Spanish; Guirao 1938:3)

c. Yo sabe [sé].

I know.PRES.3.sG

'I know.'

(Afro-Puertorican; Álvarez Nazario 1974: 194-195)

d. Nojotro trabajaba [trabajábamos] hacienda.

we work.PAST.3.sG hacienda

'We worked on the hacienda.' (Afro-Bolivian Spanish; Lipski 2008: 107)

(65) a. Ellas comía lo que yo cocinaba.

they eat.PAST.3.sG what that I cook.PAST.3.sG

'They ate what I cooked.'

b. Ello vive de eso

they live.3.sG of this

'They make a living out of this.'

c. Yo compró un pedazo de tierra.

I buy.PAst.3.sg a piece of land

'I bought a piece of land.'

d. Nosotro vivía con poca plata.

we live.PAST.3.sG with little money

'We used to live with little money'.

(66) Muy esclavizado el trabajo. Y en verano llega visitas. very enslaved the work and in summer come.PREs.3.sG visits 'The work is like slavery. And visitors come during the summer.'

9. Cf. Schwegler (2002) for an account of Palenquero subject pronouns. 
As is well-known, cases of subject-verb lack of agreement are common among L2 learners of Spanish. Lipski (1994a:208-209, 2005:253) identified similar cases in the Afro-Peruvian bozal texts he analyzed. Example (67) reports some of the instances he found.

(67) a. ¿Para qué tú me yeba?

for what you me take.PRES.3.sG

'Why do you take me?'

b. Yo neglo, yo va dicí.

I black I go.PREs.3.sG say

'I am black, I'm going to say.'

c. Yo quiele [quiero] sé diputá.

I want.PREs.3.sG be deputy

'I want to be a deputy.'

(III) Lack of subject-verb inversion in questions

Cuba (2002:37) identifies constructions that do not present subject-verb inversion in questions (68). My fieldwork confirms her data (69) and show an interesting parallelism with other Afro-Hispanic dialects as well as Caribbean Spanish and Palenquero (70).

a. ¿Ves cómo tú no crees?

see.PRES.2.SG how you no believe.PRES.2.sG

'Do you see that you do not believe?'

b. ¿Por qué el chiquito no va?

for what the kid no go.PREs.3.sG

'Why doesn't the kid go?'

(69) a. ¿Cómo uté se llama?

what you REFL call.PRES.3.SG

'What is your name?'

b. ¿Qué tú comiste en la posada? ¿Carapulcra?

what you eat.PAST.2.sG in the motel carapulcra

'What did you eat in the motel? Carapulcra?

c. ¿Cuándo tú vuelve?

when you come-back.PREs.3.sG

'When are you coming back?'

d. ¿Qué ella dijo? ¿Que yo soy listo?

what she say.PAST.3.sG that I be.PRES.1.sG smart

'What did she say? That I am smart?' 
(70) a. ¿Qué tú comes?

what you eat.PRES.2.SG

'What do you eat?'

b. ¿Onde tú taba, mijito?

where you be.PAST.3.sG my son

'Where were you, my son?' (Barlovento Spanish; Megenney 1999: 118)

c. ¿Oté tiene coca?

you have.PREs.2.sG coca

'Do you have coca?' (Afro-Bolivian Spanish; Sessarego 2011a:68)

d. ¿Ke bo ta buká akí tiela anginí Pambelé?

what you TMA look for here land back Pambelé

'What are you looking for here in this black land of Pambelé?'

(Palenquero; Schwegler 1996a: 408)

\subsection{Lexical items in Afro-Peruvian Spanish}

This section offers an account of forty lexical items characteristic of Afro-Peruvian Spanish. These words are the result of direct observations and interviews I carried out in these black communities along the Peruvian coastal region. In order to elicit lexical entries that were relevant for the Afro-Chinchano identity, at the end of each interview, speakers were asked to think about a set of words they considered to be representative of the local culture. A part of them have also been reported in the book written by Romero (1988), Quimba, fa, malambó, ñeque: Afronegrismos en el Perú, which is entirely dedicated to the Afro-Peruvian lexicon.

I. Arrebiatado: insect that attacks cotton plants.

II. Atajo de negritos: traditional Chincha dance.

III. Azumagar: to dry leaves or other parts of a plant.

Iv. Batán: a brass mortar, for kitchen use.

v. Bruja: witch who is mentioned in a variety of traditional legends.

vi. Cajon: wood drum.

vII. Catacumbas: underground tunnels located under the San José hacienda. They were built by the Jesuits and connect the hacienda to several other properties.

virI. Cau cau de mondongo: typical local dish made of rice, potatoes and tripe (mondongo).

Ix. Chandú: artifact, lie, fake object; possibly from Kikongo nzándu (joke, offense).

x. Chauca: grey bird that is supposed to bring bad luck.

xI. Chicote: whip, also called huasca, from Quechua waskha.

xII. Chivato: goatherd. 
xiII. Condesa: rich woman who used to own a local hacienda in colonial times. A local legend tells that her ghost can be seen at night on a horse wagon running across the fields.

xIv. Cuculemu: local insect.

xv. Cuculí: white bird, similar to a dove.

xvi. Cututeo: gossip, possibly from Kikongo kūtutu (to bundle up), kutama (reunion, group, to agree).

xvir. Danta: tapir; possibly from Wolof lamt (big antelope).

xvir. Guagua: child; possibly derived from Northern Zaire languages, where wa$w a$ is said to put babies to sleep, or from Quechua wáwa.

xIx. Guarango: local plant with many spines.

xx. Lingo: children's game that involves jumping around.

xxi. Lumbé: children's game where people form a circle by joining their hands; possibly from Kikongo lúmbe (joining hands).

xxir. Macuco: old person; possibly from Kimbundu kuuka (old person).

xxıI. Malambó: black neighborhood of Lima.

xxıv. Mamainé: famous traditional restaurant located in El Guayabo.

xxv. Marrajo: said of a sly person.

xxvi. Melchorita: Melchora Saravia Tasayco (Chincha, Perú, January, 61897 - December, 4 1951). Religious woman who became a nun and dedicated her life to care for the poor. She is well-knoun in Peru as 'Melchorita'. Her case is currently being considered for canonization by the Catholic Church.

xxvir. Nacudo: said of somebody with uncombed, messy hair.

xxviII. Neque: said of somebody with a strong personality, arrogant (cf. Romero 1988: 206-207).

xxıx. Ñuto: dust; possibly from Kikongo nyùka (to pulverize).

xxx. Palangana: said of somebody who is stuck-up.

xxxi. Pichingo: grey bird living on the Peruvian coasts.

xxxir. Quimba: agile movement made during traditional dances; possibly derived from the word kikimba, name of a secret language that was apparently taught to the blacks who joined the Ndembo confraternity in Peru at the beginning of the 19th century. Members of this organization practiced dance, manual skills, war tactics, and were taught this secret language (cf. Romero 1988: 226).

xxxiII. Rufa: agricultural tool used to prepare the field before placing the seeds.

xxxiv. Suró: sweat, from Spanish sudor.

xxxv. Tacutacu: traditional dish made of rice and beans.

xxxvi. Taita: father; most likely from Quechua taita (father), possibly from Kikongo taàta (father, uncle, hunt, boss, slave master).

xxxvir. Virgen del Carmen: patron saint of the El Carmen village, current folkloric and cultural center of the black Chinchano community. 
xxxviII. Zapatear: to tap one's feet, typical custom in traditional dances.

xxxix. Zarandango: traditional restaurant located in El Carmen.

xxL. ¡Újele! / ¡Yújele!: exclamation often used by children to express joy.

Some of the aforementioned lexical items could only be recalled by the oldest informants interviewed, since they refer to traditional activities or objects that are no longer in line with contemporary Afro-Peruvian lifestyle (i.e. batán, lumbé, etc.). Other items, on the other hand, were often reported by younger AfroChinchanos, since they refer to habits and/or traditions that are still alive in these Afro-Hispanic communities (i.e. cajón, zapatear, etc.). All of them, however, were indicated by the members of these communities as representative of their local identity. For this reason, they testify to a linguistic shift that is not only affecting APS phonology and morphosyntax, but also to the fact that the APS lexicon is undergoing a transgenerational change.

\subsection{A final note on Afro-Peruvian Spanish grammar}

This chapter has offered an overview of the main grammatical features characterizing traditional APS. The phonological, morpho-syntactic and lexical elements described here make traditional APS a variety of Spanish that diverges quite significantly from its surrounding dialects. At the same time, such elements align this vernacular with a number of other Afro-Hispanic varieties spoken across the Americas. The presence of these linguistic features, however, does not make APS a language apart, incomprehensible to Spanish speakers. On the contrary, we must remember that APS remains intelligible, even in its most traditional form.

As far as the status of APS is concerned, it should be pointed out that the use of the traditional dialect appears to be limited to a few elderly speakers. Indeed, the aforementioned vernacular features are for the most part absent from the speech of the younger generations. This situation can be classified as a case of transgenerational language shift, which consists of the systematic substitution of stigmatized basilectal APS features in favor of more prestigious coastal Peruvian Spanish ones. This phenomenon, driven by a recent increase in mobility and by the arrival of public education to Afro-Chinchano communities, is resulting in a drastic decline of traditional APS, which is likely to lead to its complete disappearance within a couple of generations, in line with the progressive shrinking of many other Afro-Hispanic speech varieties across the Americas (cf. Sessarego 2011a for Afro-Bolivian Sanish and Sessarego 2013c for Chota Valley Spanish). 



\section{The status of Afro-Peruvian Spanish}

\subsection{Introduction}

When we look at contemporary APS, we can certainly note some distinctive grammatical deviations from standard Spanish; nevertheless, if we had to place APS on a "creole thermometer" (cf. Lipski 2008: 183), we would probably classify this variety as something closer to a Spanish dialect, rather than a Spanish creole, to use McWhorter's (2000: 10) terminology.

According to McWhorter's (2000) Afrogenesis Hypothesis, if APS is not a creole, it is because Spain did not have slave castles in Africa, since the conditions for a creole to emerge in colonial coastal Peru would have been optimal. In his view, creoles developed out of pidgins, and since a Spanish pidgin could not be introduced on the American plantations, a creole could not possibly form. On the contrary, the supporters of the decreolization model would suggest that APS might well have been a creole in colonial times, and that due to more recent contact with local varieties of Spanish it would have approximated to it over time, thus decreolizing. Indeed, at a couple of recent linguistic conferences some creolists from the audience have pointed out to me that the communities under discussion are not geographically isolated, so that when the hacienda system ended in the 1960s, Afro-Peruvians acquired more mobility and could engage in extensive sociolinguistic contact with monolingual Spanish speakers from surrounding areas. For this reason, it could be possible that APS might have been more restructured/creolized than what it is today. This is a valuable point and it could very well describe what happened in these Chincha communities. In fact, since no written diachronic linguistic data for these specific villages are available, we know virtually nothing about the earlier phases of Chinchano speech. For this reason, we may never be completely sure that a creole language was not used in this region centuries ago. Nevertheless, I remain of the view that clear sociohistorical and linguistic evidence should be provided to build a convincing theory of (de)creolization. The reconstruction of historical facts is always an approximation; it is never exact. The best way to proceed is to try to make sense of the data we have. For this reason, I do not pretend that my version of the story is perfect or the correct one; rather, I attempt to build a story that appears to be the most 
likely one, based on the available information, and the available information we have, as we will see in Chapter 5, does not appear to back either the Afrogenesis Hypothesis or the Decreolization Hypothesis.

What I would like to propose is that APS, as well as many other Afro-Hispanic vernaculars, can actually be seen as an advanced conventionalized second language (cf. Sessarego 2013b). This proposal breaks with the traditional creole life-cycle adopted by some authors according to whom pidgins become creoles and then eventually decreolize. On the other hand, I wish to stress that the aforementioned path (pidginization $\rightarrow$ creolization $\rightarrow$ decreolization) is only one of many potential forms of contact-induced restructuring. Indeed, if we look at the contact varieties that emerged in the Americas due to the contact among African and European languages, we may observe a wide variety of linguistic outputs. Alleyne (1980: 181) reminds us that:

Afro-American dialects can be plotted on a scale representing different degrees of transmission of West African elements, and differentials in degrees of transmission that are to be explained by differences in sociolinguistic circumstances in each area.

Alleyne's words can be rephrased by saying that these dialects may be placed on a continuum ranging from close approximations to the lexifiers to radical creoles.

While the fact that contact-induced restructuring operates on a cline is wellknown in Creolistics (cf. Thomason \& Kaufman 1988; Siegel 2008), oftentimes people tend to assume that a vernacular currently found on the left side of the spectrum (see Figure 4.1) must have ended up there after an incremental leftward shift, thus suggesting that in the past it was more radical. This assumption, which pictures a gradual decreolization path, is somewhat misleading and, in several cases, clearly goes against the documented historical evolution of some presentday creoles, which appear to have become more 'radical' during the last couple of centuries; i.e. Haitian French (Lefebvre 1998) and Sranan Tongo (Migge 2003).

$\leftarrow$ Slight substrate retention $\leftarrow \rightarrow$ Moderate $\leftarrow \rightarrow$ Extreme L1 retention $\rightarrow$

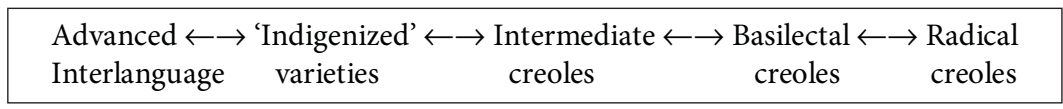

Figure 4.1 A continuum of outcomes involving degrees of substrate and L2 input (Winford 2000:216) 


\subsection{Creoles as Interlanguages}

Schumann (1978) and Andersen $(1980,1983)$ were among the first scholars to identify a link between Second Language Acquisition (SLA) and Creole studies. They hypothesized that pidginization may be seen as the early stages of SLA. In more recent years, Creolistics and SLA have developed stronger connections leading to a very productive interdisciplinary dialogue (cf. Kouwenberg \& Patrick 2003; Lefebvre et al. 2006; Siegel 2008).

One of the latest attempts to build a theory of creole genesis based on an SLA framework is Plag's (2008a, b; 2009a, b) Interlanguage Hypothesis of Creole Formation, which relies on Pienemann's $(1998,2005)$ Processability Theory. What is interesting about this approach is that it tries to account for the fact that there seems to be a common universal path in the development of second languages, independently of the speaker's L1. The model relies on psycholinguistic accounts of speech production such as those designed by Kempen and Hoenkamp (1987) and Levelt (1989). The central claim of Processability Theory is that the processing procedures follow a hierarchy of activations in language generation, which, in turn, drives their sequence of acquisition. Plag adopts this model to account for certain aspects of creole languages (e.g. loss of inflectional morphology, the unmarked nature of many syntactic structures, the conflation of phonological categories, circumlocutions, etc.). His Interlanguage Hypothesis of Creole Formation goes as far as to state that creoles can be seen as conventionalized interlanguages of an early stage. Plag (2008a) also points out that SLA processes in creolization do not necessarily imply substrate transfer, as it has often been suggested in the literature. On the other hand, there may be transfer without SLA as, for example, in cases of early bilingualism (Kouwenberg 2006), and there are SLA processes involved in creolization that cannot be labeled as 'transfer', but rather they should be analyzed as gradual interlanguage evolutions, which obey hierarchical chronological steps (Siegel 2008). In the present chapter, I will not go into the details of Plag's model, since the author developed it to account for 'radical' creole varieties. However, I want to acknowledge its importance by highlighting the idea that there is a clear universal hierarchy of second language acquisition and that it plays a crucial role in shaping the grammar of all contact languages.

The present chapter will analyze some cross-linguistic similarities that can be found in Afro-Peruvian Spanish and in the rest of the Afro-Hispanic varieties spoken in the Americas, which have been traditionally seen as the residue of a previous creole stage. I will propose that these features are, indeed, common traces of advanced SLA strategies (rather than of early ones). In so doing, I hope to convince the reader that - at least from a linguistic perspective - the grammatical elements encountered in these varieties should not necessarily be seen as the 
result of decreolization; rather, they can be explained as the expected byproduct of advanced SLA processes. This, however, does not imply that decreolization is impossible. My personal opinion is that it might well have happened for certain languages, but to support such a claim we need to provide clear socio-historical and linguistic evidence, since the presence of advanced SLA features in these contact varieties does not support per se any previous (de)creolization hypotheses.

\subsection{The proposal}

I would like to propose that APS, as well as several other Afro-Hispanic contact varieties, can be seen as the result of L1 acquisition (nativization) of advanced L2 grammars. This statement is based on the assumption that L1 and L2 acquisition are driven and constrained by Universal Grammar (UG). During childhood, first language acquisition develops naturally and instinctively - provided the child is exposed to enough linguistic input. L2 development operates somewhat differently. L2 speakers have access to UG, but biological and social factors conspire against the full mastery of the target language (TL). In fact, the loss of spontaneity of acquisition and incomplete command of the L2 morpho-lexicon are two inevitable consequences of biological age maturation. Moreover, certain social aspects of L2 acquisition, such as lack of motivation, acculturation and free time, often contribute to the incomplete mastery of the L2 (Herschensohn 2000: Ch. 3).

The basic idea behind the nature of several Afro-Hispanic dialects is that African slaves had relatively good access to Spanish (the TL), which allowed them to achieve a certain degree of mastery in it. Thanks to UG, each individual internalized one grammar out of a set of possible grammars (G1, G2, Gn). Their linguistic outputs $(\mathrm{x}, \mathrm{y}, \mathrm{z})$ served as the primary linguistic data (PLD) for the following generation, which acquired this language natively. This model can be schematically represented in (71), where Grammar 1 (G1) and Grammar 2 (G2) represent two possible grammars with different parametric configurations: ${ }^{10}$

(71) a. Individual from Generation 1:

TLy $\rightarrow$ UG driving L2 acquisition $\rightarrow$ G1 $\rightarrow$ set of outputs X

b. Individual from Generation 2:

$\mathrm{PLDx} \rightarrow \mathrm{UG}$ driving L1 acquisition $\rightarrow \mathrm{G} 2 \rightarrow$ set of outputs $\mathrm{Z}$

10. Cf. Pires \& Thomason (2008) and Pires \& Rothman (2009) for a similar account of crossgenerational language change. The main difference between their accounts and the present one lies in the fact that example (71) pictures a case of contact-induced change, where SLA processes are involved. See also Veenstra (2008:234-235) for a similar yet different account of nativization in creole genesis. 
In this model, the $\mathrm{L} 1$ acquisition of Generation 2 represents the process of nativization. The result of this is an L1 grammar (G2), built on L2 inputs. G2, therefore, will present crystallized aspects of an L2, which are acquired as an L1.

\subsection{The Afro-Hispanic varieties of the Americas}

There are regions of Latin America where Afro-Hispanic people represent the majority of the population. Perl (1998) provides a report of the geographical distribution of black communities across this area. He includes Cuba, Puerto Rico, the Dominican Republic, parts of Northern Colombia and Venezuela, the coastal regions of Honduras, Nicaragua, Costa Rica, Panama, the Pacific coastal regions of Colombia, Peru and Ecuador, as well as some small minorities in Mexico, Belize, and Trinidad and Tobago. The Bolivian region of Los Yungas, home of an Afro-Hispanic group recently brought to the attention of the linguistic community by Lipski (2008), should also be added to this list. Klee and Lynch (2009:6) offer an updated version of Perl and Schwegler's (1998:3) map to account for these geographic regions (Figure 4.2).

In the rest of this section, I will focus on some common features that have repeatedly been reported for the vast majority of these Afro-Hispanic dialects (e.g. Afro-Venezuelan Spanish (Megenney 1999); Afro-Bolivian Spanish (Lipski 2008); Afro-Caribbean Spanish (Álvarez Nazario 1974; Lorenzino 1998; Álvarez \& Obediente 1998); Afro-Peruvian Spanish (Lipski 1994a); Afro-Mexican Spanish (Mayén 2007); Afro-Panamanian Spanish (Lipski 1989); Chocó Spanish (RuizGarcía 2009); Chota Valley Spanish (Lipski 1987); etc.) and in some cases have been identified as potential indicators of a previous creole stage.

The goal here will be to show that these features can actually be explained as advanced SLA phenomena, which do not necessarily imply any previous (de)creolization phase for the languages presenting them. In particular, I will discuss: (a) use of non-emphatic, non-contrastive overt subjects; (b) invariant verb forms for person and number; (c) lack of nominal gender and number agreement; (d) presence of bare nouns in subject and object position; and (e) non-inverted questions. Table 4.1 reports such features with examples taken from some of the Afro-Hispanic dialects presenting them.

All of the features reported in Table 4.1 as potential indicators of a previous creole stage for the Afro-Hispanic dialects of the Americas are also encountered in APS (cf. Chapter 3). Table 4.2 provides a summary of such morpho-syntactic phenomena in APS. 


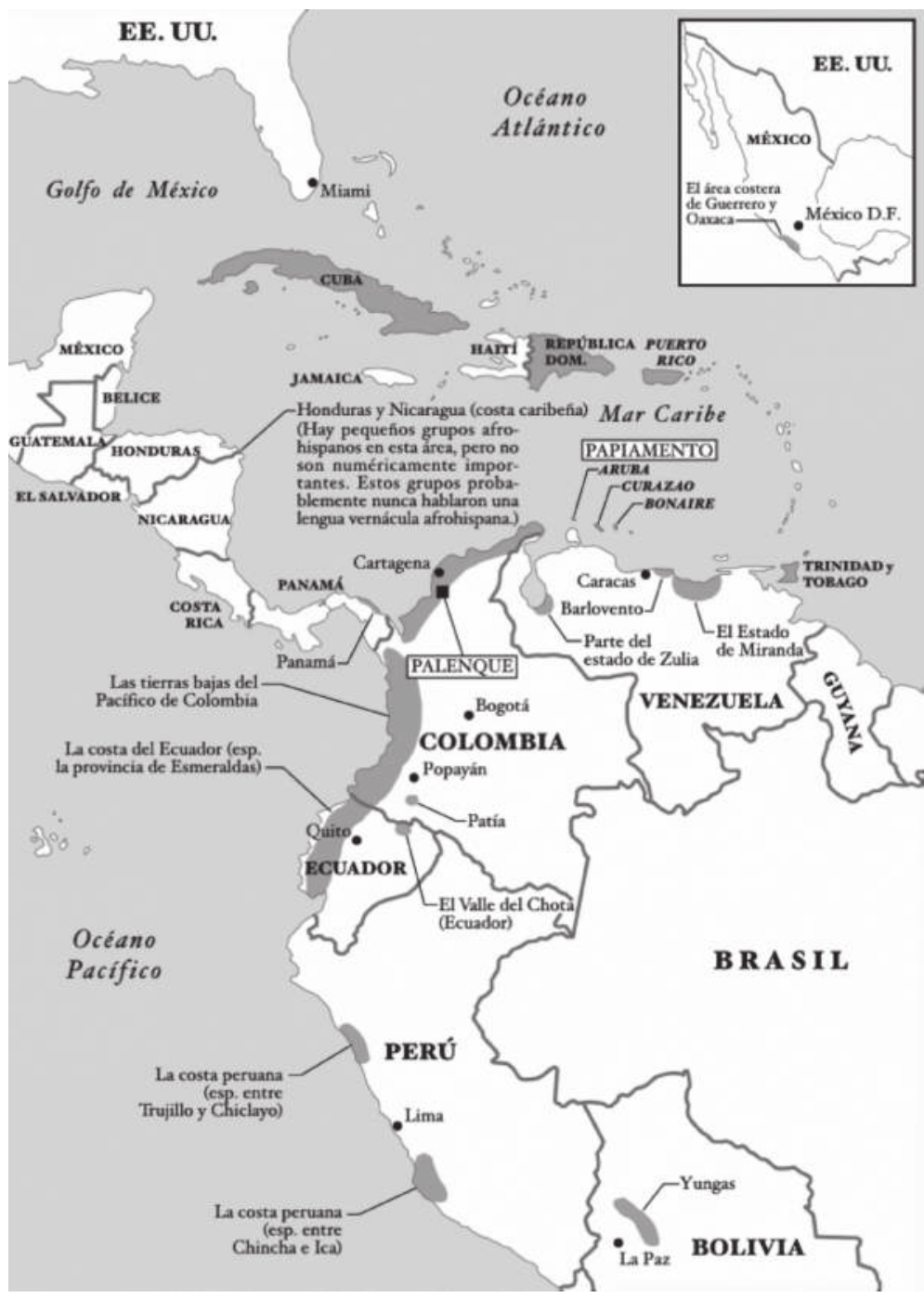

Figure 4.2 The Afro-Hispanic regions of Latin America (Klee \& Lynch 2009: 6, adopted from Perl \& Schwegler 1998:3)

The second column of Table 4.2 not only offers examples extracted from my corpus, it also includes data provided by Lipski (1994a), Gálvez Ronceros (1975), and Cuba (2002). Indeed it is of interest to see how these grammatical features appear in a variety of historical Peruvian literary texts reproducing bozal speech (cf. Lipski 1994a), in Gálvez Ronceros' novel (1975) Monólogo desde las tineblas, which consists of a collection of stories depicting contemporary Afro-Peruvian 
Table 4.1 Five commonly reported Afro-Hispanic features traditionally ascribed to a previous creole stage

\begin{tabular}{|c|c|}
\hline Phenomenon & Examples \\
\hline \multirow[t]{2}{*}{$\begin{array}{l}\text { Use of non-emphatic, } \\
\text { non-contrastive overt subjects. }\end{array}$} & $\begin{array}{l}\text { Yo tando muy pequeña yo conocí a una señora. } \\
\text { 'When I was young I met a woman.' } \\
\text { (Barlovento Spanish; Megenney 1999: 117). }\end{array}$ \\
\hline & $\begin{array}{l}\text { Claro yo como fue chico yo no acorda vela. } \\
\text { 'Obviously since I was I child I do not remember candels.' } \\
\text { (Afro-Bolivian Spanish; Lipski 2008: 101). }\end{array}$ \\
\hline \multirow[t]{2}{*}{$\begin{array}{l}\text { Invariant verb forms for person } \\
\text { and number. }\end{array}$} & $\begin{array}{l}\text { Yo sabe [sé] 'I know'; yo tiene [tengo]. 'I have'; } \\
\text { yo no pue [puedo] 'I cannot.' } \\
\text { (Afro-Puertorican; Álvarez Nazario 1974: 194-195). }\end{array}$ \\
\hline & $\begin{array}{l}\text { Tú jabla [hablas] y no conoce [conoces]. } \\
\text { 'You speak and you do not know.' } \\
\text { (Afro-Cuban Spanish; Guirao 1938:3). }\end{array}$ \\
\hline \multirow[t]{2}{*}{$\begin{array}{l}\text { Lack of nominal gender and } \\
\text { number agreement. }\end{array}$} & $\begin{array}{l}\text { Tán chiquito puej mij nene[s]. } \\
\text { 'My kids are so little.' } \\
\text { (Afro-Mexican Oaxacan Spanish; Mayén 2007: 117). }\end{array}$ \\
\hline & $\begin{array}{l}\text { Gente branco [blanca]. } \\
\text { 'White people.' } \\
\text { (Cuban Bozal Spanish; Álvarez Nazario 1974: 189). }\end{array}$ \\
\hline $\begin{array}{l}\text { Lack of subject-verb inversion } \\
\text { in questions. }\end{array}$ & $\begin{array}{l}\text { ¿Onde tú taba, mijito? } \\
\text { 'Where were you, my son?' } \\
\text { (Barlovento Spanish; Megenney 1999: 118). } \\
\text { ¿Qué tú comes? } \\
\text { 'What do you eat.' } \\
\text { (Caribbean Spanish; Lorenzino 1998:36). }\end{array}$ \\
\hline
\end{tabular}

Presence of bare nouns.

Me metía en [el] pueblo con [los] trabajadores.

'He put me in the village with the workers.'

(Chocó Spanish; Ruiz-García 2009:45).

Porque [el] próximo pueblo puede ser Salinas.

'Because the next town could be Salinas.'

(Chota Valley Spanish; Lipski 1987: 163).

communities in Chincha, and have also been reported in Cuba's (2002) linguistic survey of the area. These examples confirm that traditional APS is an AfroHispanic dialect quite divergent from standard Peruvian Spanish and that derived from the Spanish spoken by the black slaves in colonial times. Nevertheless, the features found in this language should not be taken as indicators of a previous 
Table 4.2 Common Afro-Hispanic features found in Afro-Peruvian Spanish

\begin{tabular}{ll}
\hline Phenomenon & Examples \\
\hline Use of non-emphatic, & Cuando yo ta la congreso, yo neglo, yo va dicí ... \\
non-contrastive overt subjects. & 'When I go to the congress, I am black, I am going to \\
& say...' (Lipski 1994a: 208). \\
& Mauricio fue también. Él se tomó una botella de cerveza y \\
& después él se fue de fiesta. \\
& 'Mauricio went too. He drank a bottle of beer and after- \\
& wards he left to have fun.' (current book, Chapter 3). \\
\hline Invariant verb forms for person & $\begin{array}{l}\text { Yo compró un pedazo de tierra. } \\
\text { and number. }\end{array}$ \\
& 'I bought a piece of land.' (current book, Chapter 3). \\
& Muy esclavizado el trabajo. Y en verano llega visitas. \\
& 'The work is much enslaved, uu! And visits come during \\
& the summer.' (Cuba 2002: 38). \\
\hline
\end{tabular}

Lack of nominal gender and La mula esta flacucho.

number agreement.

'The female mule is skinny' (Lipski 1994a: 192).

Santa María tiene sus ola como un río.

'St. Mary has waves like a river.' (Cuba 2002:37).

Lack of subject-verb inversion ¿ ¿Ves cómo tú no crees?

in questions.

'Do you see that you do not believe?' (Cuba 2002:37).

¿Qué ella dijo?

'What did she say?' (current book, Chapter 3).

Presence of bare nouns. Niño no responde nara.

'The kid does not say anything.' (Lipski 1994a: 209).

Susijos no repetan [la] gente mayó.

'His sons do not respect old people.'

(Gálvez Ronceros 1975:20).

creole stage. In fact, these grammatical elements appear to be frequently encountered in a number of advanced L2 varieties, thus indicating that they should not be necessarily accounted for by postulating a creole hypothesis (cf. Sessarego 2011b, 2013b). 


\subsection{Afro-Peruvian Spanish as an advanced conventionalized second language}

I will now proceed with a closer analysis of these commonly recurring features to show that not only are they not diagnostic of creoleness; rather, they often can be found in quite advanced interlanguages.

Use of non-emphatic, non-contrastive overt subjects is a linguistic phenomenon related to the acquisition of the null-subject parameter (cf. Camacho 2013 for a review). Subject expression in null subject languages like Italian or Spanish requires the mastery of the syntactic/pragmatic interface, since both structural and discourse features are involved. In fact, the null subject (pro) is usually used in topic and non-contrastive focus contexts. An example of the use of pro in Spanish is provided by Montrul et al. (2009:303) in (72), where it expresses old information.

(72) Juan llegó

a su casa del trabajo. Primero [pro] se

Juan arrive.PAST.3.sG to his house from the job. First

REFL

cambió de ropa y luego [pro] decidió

change.PASt.3.sG of clothes and after decide.PASt.3.sG

ponerse a preparar la cena.

begin.PRES.3.sG to prepare the dinner

'Juan came home from work. First he changed his clothes and then he decided to make dinner.'

SLA studies on the acquisition of such a parameter have long reported the overproduction of overt subjects in contexts requiring a null realization (White 1985, 1986; Phinney 1987). In particular, recent findings have suggested that even advanced L2 learners tend to show a surplus of overt subject pronouns because topic features are complex to acquire and therefore a native-like use of overt and covert pronouns is not likely to be obtained (Sorace 2000, 2003, 2004). In fact, according to Grimshaw and Samek-Lodovici (1998), the subject pro in a pro-drop language would come with a [+topic shift] feature, while such a category - and its correspective feature specification - would not be available in non-pro-drop languages, where all subject pronouns must be spelled out.

These data are perfectly in line with the idea that some aspects of AfroHispanic contact varieties should be seen as advanced second language phenomena. In fact, given that the correct use of pro in Spanish implies the simultaneous proficient knowledge of syntactic and pragmatic features, encountering an overuse of non-emphatic, non-contrastive overt subjects in these dialects is not completely unexpected. 
Another aspect of natural languages which involves the interaction of two different linguistic dimensions (syntax and semantics) has to do with the acquisition of uninterpretable phi-features (gender, person, number). In fact, current syntactic theory (Chomsky 1995) distinguishes between interpretable and uninterpretable features. Certain features have an interpretation at Logic Form (LF), thus they are semantically interpretable elements. Other features, on the contrary, lack such semantic import and are present in the system to trigger necessary syntactic operations during the derivation. One such operation is Agree. Chomsky $(2000,2001)$ argues that Agree consists of a relation between two elements within a syntactic domain: a probe and a goal. Chomsky suggests that agreement is the consequence of a situation in which an unvalued instance of a feature F c-commands another instance of $F$. The probe consists of an unvalued set of phi-features on a functional head, which is uninterpretable as such and must receive a value from some other syntactic constituent (Béjar 2008: 133-134). According to this view, Agree serves the purpose of deleting uninterpretable features, which are unreadable at the syntax/semantic interface and - if not eliminated - would cause the derivation to crash. Deletion takes place in a cyclical fashion at the end of each phase. As uninterpretable phi-features do not contribute to the semantic interpretation of phrases, the complete mastery of such elements occurs late in L2 acquisition and often times is not obtained (Franceschina 2002). As far as Spanish L2 grammars are concerned, the slow acquisition of phi-feature specifications results in Spanish interlanguages presenting varying degrees of morphological marking incompleteness across their nominal and verbal domains.

For this reason, invariant verb forms for person and number are frequent among L2 varieties of Spanish and in child language (Bybee 1985). In these cases, the use of 3 rd person singular as the default form is common. In addition, recent studies on the evolution of creole languages have ascribed the use of this form to its high frequency in natural speech and to its consequent higher learnability in language acquisition processes (Clements 2009; Clements \& Koontz-Garboden 2002; Pinharanda Nunes 2013). The Afro-Hispanic dialects found in the Americas display variable levels of subject-verb (dis)agreement, which in turn reflect an aspect of their degree of restructuring (cf. Figure 4.1). In some varieties, 3rd person singular default forms can be commonly encountered (e.g. Afro-Bolivian Spanish), while in others, they are very rare (e.g. Chota Valley Spanish).

Cases of variable subject-verb agreement can be formally captured by postulating that in these dialects two different Tense Heads (T) are potential candidates to enter the lexical numeration: T1 and T2 (cf. Adger \& Smith 2005 for a similar account for Buckie English). T1 bears tense, case, number and person features, like in standard Spanish; while T2 lacks number and person features. The result of the operation Agree (and Merge) between a subject pronoun and T1 will be a 
verb form conjugated for tense, number and person. On the other hand, the same operation involving T2 will result in a verb form conjugated for tense, but showing default features for number and person. These operation can be schematically represented for the verb bailar 'to dance' and the pronoun nosotros 'we' in examples (73) and (74).

(73) T1 [tense:present, $u$ case:nom, unum:, upers:] ... pronoun [num:pl, pers:1, ucase: $] \rightarrow$

$\rightarrow$ T1 [tense:present, $u$ case:nom, unum:pl, upers:1] ... pronoun [num:pl, pers:1, ucase:nom]

Result: Nosotros bailamos

we.NOM dance.PRES.1.PL

(74) T2 [tense:present, $u$ case:nom] ... pronoun [num:pl, pers:1, ucase:] $\rightarrow$ $\rightarrow$ T2 [tense:present, $u$ case:nom] ... pronoun [num:pl, pers:1, ucase:nom] Result: Nosotros baila we.NOM dance.PRES.3.SG

The processing challenges held responsible for the slow acquisition of subject-verb agreement also apply to the mastery of gender and number features within the nominal domain. In fact, a variety of studies have reported the systematic presence of masculine/singular default values across the L2 Spanish determiner phrase (White et al. 2004; Sagarra \& Herschensohn 2008, 2011). Recent research in Creolistics has suggested a clear hierarchy of gender/number agreement acquisition, where the development of agreement begins on determiners (in particular, on definite articles) and then, eventually, spreads to other grammatical categories (cf. Sessarego \& Gutiérrez-Rexach 2011, 2012; Gutiérrez-Rexach \& Sessarego 2014; Sessarego 2013e).

This is in line with previous findings in SLA in Romance. In fact, Hawkins (1998) showed that English students speaking French as a second language presented more agreement on definite articles than on indefinite ones, and also more agreement on determiners than on adjectives. Similar findings have also been reported for English speakers of Spanish by Bruhn de Garavito and White (2000), and more recently by Franceschina (2005) who tested advanced speakers of Spanish coming from a variety of backgrounds (Italian, Portuguese, English, Arabic, German and French). Moreover, it must be said that APS and the Afro-Hispanic dialects reported here do not lack gender/number features. Rather, the main distinction between them and standard Spanish concerns the nominal elements agreeing with the noun. In fact, while in standard Spanish, adjectives, articles, demonstratives and quantifiers all agree in gender and number with the noun, nominal concord in these Afro-Hispanic dialects is restricted to a sub-group of categories, depending on the dialect. Most importantly, the fact that only some 
grammatical categories present gender agreement implicitly attests to the presence of 'gender' as a grammatical feature in these varieties, thus showing a contrast with the majority of the Romance-based creoles, in which such an agreement feature is not usually found. This fact further suggests that this aspect of the AfroHispanic dialects of Latin America should be seen as an advanced interlanguage phenomenon. It must be said that, if corrected through formal instruction, advanced L2 students may present stronger agreement patterns. However, given that the sociohistorical scenarios in which these dialects emerged have never been characterized by formal education, it is not completely surprising to encounter gender, number and person default forms in several Afro-Hispanic varieties.

In line with the computations represented in (73)-(74) for cases of subjectverb agreement, examples (75)-(76) depict agreement processes involving gender and number features in the DP. In example (75) we can observe the determiner (D1) and the noun (N1) coming from the lexicon with the standard specification for gender and number features, while in (76) some of those specifications are missing from D2 and N2, thus leading to a different surface result characterized by impoverished agreement. ${ }^{11}$

(75) D1 [ugen:, unum:] ... Num[num:pl] ... N1 [gen:f, unum:] $\rightarrow$ $\rightarrow$ D1 [ugen:f, unum:pl] ... Num[num:pl] ... N1 [gen:f, unum:pl]

Result: Muchas gatas

many.F.PL cat.F.PL

(76)

D2 [ ] ... Num[num:pl] ... N2 [gen:f] $\rightarrow$
$\rightarrow$ D2 [ ] .. Num[num:pl] ... N2 [gen:f]
Result: Mucho gata
$\quad$ many.M.SG cat.F.SG

Bare nouns, deprived of an overt article, have often been reported in relation to creole languages (cf. Baptista \& Guéron 2007). Nevertheless, a variety of studies in second language acquisition have shown that mastering the article system of a foreign language may be very challenging, especially if the learner comes from an L1 presenting an article system typologically different from the one encountered in the L2 (Sánchez \& Giménez 1998; Leonini 2006; García Mayo \& Hawkins 2009). The Afro-Hispanic dialects of the Americas may present article systems that diverge from standard Spanish. In traditional APS, for example, there are

11. Examples (75)-(76) should be seen as oversimplifications of the actual agreement processes taking place in several Afro-Hispanic languages. A more detailed account of such phenomena can be found in Sessarego \& Gutiérrez-Rexach (2011, 2012); Delicado-Cantero \& Sessarego (2011); Sessarego (2013e, 2014a); Gutiérrez-Rexach \& Sessarego (2014); Sessarego \& Ferreira (in press). 
four definite articles (el, la, los, las), presenting overt number and gender agreement, and two indefinite ones (un, unos), agreeing only in number. Their use parallels - for the most part - that of standard Spanish, even though bare nouns can appear in argument position. The semantic interpretation of such bare nominals may vary depending on the pragmatic context (e.g. plural/singular, specific/ generic). In this respect, Afro-Peruvian Spanish resembles Afro-Bolivian Spanish to a great extent (cf. Gutiérrez-Rexach \& Sessarego 2011 for a detailed account).

APS, in line with several other Afro-Hispanic dialects and with Caribbean Spanish varieties, allows for constructions in which a fronted wh-operator (wh-op) is followed by preverbal subjects when the wh-operator is an argument (77), thus giving rise to both wh-S-V and wh-V-S questions.

(77) Afro-Hispanic/Caribbean varieties

a. ¿Qué tú comes?

what you eat.PREs.2.sG

'What do you eat?'

b. ¿Qué comes (tú)?

what eat.PRES.2.sG you

'What do you eat?'

Conversely, wh-S-V constructions are not generally grammatical in Mainland Spanish dialects, so that only the wh-V-S pattern is allowed (78).

(78) Mainland Spanish

a. ${ }^{*}$ ¿Qué tú comes?

what you eat.PREs.2.sG

'What do you eat?'

b. ¿Qué comes (tú)?

what eat.PRES.2.sG you

'What do you eat?'

Within the generative SLA tradition, several studies have been carried out to understand how wh-movement and subject-verb inversion are acquired and to test whether UG is available during L2 development. The conclusions on the accessibility of UG during L2 acquisition have been variable but results have suggested that the mastery of such structures may be difficult to obtain, especially if the learner's L1 does not present such constructions (e.g. in Chinese, Korean, and Japanese; cf. Birdsong 1992; Johnson \& Newport 1989; Martohardjono \& Gair 1993; White 1992; White \& Juffs 1998; etc.).

Since the co-occurrence of fronted wh-operators and preverbal subjects is a common feature of Spanish creoles (cf. Holm \& Patrick 2007), a potential creole origin for the Spanish dialects showing this characteristic has often been 
suggested (e.g. Perl 1998). There are at least two facts that seem to weaken such a hypothesis. First, SLA studies have shown that non-inverted questions also appear cross-linguistically in very advanced stages of SLA (Pienemann 1998, 2005), thus indicating that they are not necessarily indicative of "creoleness". Secondly, it should be pointed out that while Afro-Hispanic and Caribbean varieties show $w h-S-V$ constructions (cf. (77)), the wh-V-S order is also commonly used and quantitative studies indicate that it is actually the most frequent one for Dominican Spanish (cf. Gutiérrez-Bravo 2008:227). Nevertheless, traditionally, the analysis of Caribbean $w h-S-V$ interrogative constructions has been contrasted with the $w h-V-S$ structures found in Mainland Spanish. A recent account by GutiérrezBravo $(2005,2007,2008)$ stresses the importance of keeping in mind that (77a) and (77b) should not be analyzed as equivalent constructions in two different dialects; indeed, he shows that both of them co-exist in Caribbean Spanish and are based on different structures used in diverse pragmatic contexts. Conversely, in Mainland Spanish, (78a) is not a grammatical option. Its equivalent is (79), where the subject is a sentence topic displaced to the left-peripheral position.

\section{(79) Tú ¿qué comes? you what eat.PRES.2.sG 'What do you eat?'}

Gutiérrez-Bravo $(2005,2008)$ formulates the following Interrogative Clause Condition to explain the Extended Projection Principle (EPP) ${ }^{12}$ (cf. Chomsky 1982) requirement associated with interrogative clauses: A clausal Extended Projection is interrogative if the head of the highest phrase in the Extended Projection bears the feature $[\mathrm{Q}]$. After formulating this condition, Gutiérrez-Bravo claims that in sequences similar to (77b), TP is the highest projection, wh-op lands in [Spec, $\mathrm{T}]$, and $\mathrm{T}^{\circ}$ acquires a [Q] feature from Spec-Head agreement with the wh-op. The presence of $w h$-op in [Spec, T] satisfies the EPP requirement instantiated by such a position, so that the subject remains in its VP internal position, as shown in (80). On the other hand, in (77a), the wh-operator lands in [Spec, C] so that $\mathrm{C}^{\circ}$ acquires its [Q] feature. Since [Spec, T] is empty, a topicalized subject will be able to land there and satisfy the EPP requirement, as shown in (81).

$$
\begin{aligned}
& {\left[_{\text {TP }} \text { Qué }_{\mathrm{i}} \quad \text { comes }_{\mathrm{j}}\left[{ }_{\mathrm{VP}} \text { tú } \mathrm{t}_{\mathrm{j}} \mathrm{t}_{\mathrm{j}}\right]\right] \text { ? }} \\
& \text { wh } \mathrm{T}^{\circ} \\
& {[\mathrm{Q}] \rightarrow[\mathrm{Q}]}
\end{aligned}
$$

12. The Extended Projection Principle (EPP) states that all verbs require a subject (cf. Chomsky 1981, 1995, 2000; Lasnik 2001a, b). 


$$
\begin{gathered}
\text { [CP Qué }{ }_{i} \quad \varnothing\left[\mathrm{TP} \text { tú }_{\mathrm{j}} \text { comes }_{\mathrm{k}}\left[\mathrm{VP} \mathrm{t}_{\mathrm{j}} \mathrm{t}_{\mathrm{k}} \mathrm{t}_{\mathrm{i}}\right]\right] \text { ? } \\
\text { wh } \mathrm{C}^{\circ} \\
{[\mathrm{Q}] \rightarrow[\mathrm{Q}]}
\end{gathered}
$$

The presence of two diverse constructions to express two different types of questions may appear as an additional complexity incorporated by some AfroHispanic dialects. At first glance, this fact may seem counterintuitive from a second language acquisition perspective, since contact linguistic phenomena tend to favor the acquisition of less complex/unmarked structures. This is an issue that deserves more attention; it should be analyzed by considering the sociolinguistic and diachronic evolution of the wh-S-V construction in the dialects which present it. Nevertheless, for the moment, a highly speculative answer could be provided if we assume that, due to processability constraints on L2 production (cf. Pienemann 2005), the PLD of a certain generation may have been quite variable (including both inverted and non-inverted questions). Assuming such a scenario, it is not completely unreasonable to think that two different interpretations might have been assigned to such constructions by the acquiring children, so that in their L1 (77a) came to represent the topicalized subject question that would be normally expressed with (79) in other Spanish dialects.

\subsection{A final note on the status of Afro-Peruvian Spanish and other Afro-Hispanic contact varieties}

The linguistic evidence provided in this chapter has shown that certain aspects of the Afro-Hispanic dialects, often reported in relation to their potential creole origin, can be accounted for as the result of conventionalized advanced SLA strategies. APS, in this respect, fits perfectly with the rest of these vernaculars. This variety presents exactly those features that several scholars would see as symptomatic of a previous creole stage: the use of non-emphatic; non-contrastive overt subjects; invariant verb forms; lack of gender and number agreement across the nominal domain; non-inverted questions; bare nouns. ${ }^{13}$ This study, however, has

13. Schwegler (p. c.) points out that some Afro-Hispanic and Afro-Lusophone languages (i.e. Popular Brazilian Portuguese, Palenquero, Chocó Spanish, Dominican Spanish, Annabón, São Tome, Principense, etc.) share double negation of the type yo no como no 'I do not eat'. He claims that this would be a construction modeled on Kikongo, which may indicate that these varieties would have developed from a single Afro-Portuguese pidgin/creole language spoken on both sides of the Atlantic in colonial times (Schwegler 1993:76-77). APS does not present this feature; for this reason, the Afro-Portuguese link cannot be invoked to account for its origin. Moreover, as I have previously explained, I personally do not agree with Schwegler's 
shown that such grammatical elements can be described as the byproduct of advanced second language acquisition phenomena, which do not necessarily imply any (de)creolization phase. The analysis here offered, therefore, breaks with the traditional creole life-cycle (pidginization $\rightarrow$ creolization $\rightarrow$ decreolization) that certain scholars would propose to account for the genesis and evolution of these dialects. The following chapter will corroborate this linguistic proposal for APS with socio-historical information concerning black slavery in colonial Peru.

monogenetic view on the evolution of the Afro-Hispanic dialects spoken across the Americas (Sessarego 2013c). Nevertheless, I must admit that this is an issue that deserves further attention. In fact, it would be important to understand to what extent all the above mentioned languages present exactly the same negative constructions. Unfortunately, as far as I know, a detailed comparative study of these constructions in such varieties has not been carried out yet. Schwenter (2005) has investigated the nature of such negation forms in Brazilian Portuguese to conclude that their grammatical function is to deny a discourse-old proposition (2005: 1453). As a note, it must be said that a similar function has also been identified for parallel negation forms in Italian and Catalan (Visconti 2009; Schwenter 2002), two Romance languages for which a Kikongo substrate cannot be invoked. 


\section{Black slavery in Peru}

\subsection{Introduction}

Black slavery lasted in Peru for almost four centuries. It was originally brought over from the Iberian Peninsula with the Spanish invasion, during the first decades of the 16th century, and was officially abolished only in 1854, under the presidency of Ramón Castilla y Marquezado, several decades after independence from Spain in 1824. However, as in the rest of Latin America, the official abolition of slavery, in practice, did not provide Afro-descendants with the same degree of freedom enjoyed by the white and mestizo sectors of the population. In fact, until the Agrarian Land Reform, which took place during the years 1963-1979, the majority of the Afro-Peruvians working on rural estates lived as peons, in a semifeudal system: they were forced to work for free on haciendas four days a week, did not own land, and were provided with a small lot to work for their own benefit during their time off. These working dynamics long deprived Afro-Peruvians from social security and education. The wide-spread illiteracy resulting from this situation systematically excluded the black community from political representation until 1979, when the new constitution extended the right of voting to the uneducated sector of the population. Even today, the living conditions of black Peruvians are far from being optimal. A part of them live in urban suburbs, where they usually have blue-collar jobs, or work as domestic maids and guards; the rest predominantly inhabit the coastal rural regions of the country (e.g. Yapatera and Chapica, Department of Piura; Zaña and Bigote, Department of Lambayeque; Loredo and Cartavio, Department of La Libertad; a variety of other villages in the Departments of Ica, Moquegua and Tacna), where they typically make a modest living by growing cotton, grapes, sugarcane and rice on the small land parcels they were assigned after the Land Reform (cf. Cuba 2002:17).

As Carlos Aguirre (2005) states, black slavery is a long-lasting "scare" in Peruvian history, and since it spans across a period of almost four hundred years, it cannot be studied in a homogeneous way. For this reason, I will attempt to examine this unfortunate episode of Peruvian history by breaking it down into three main phases, which may facilitate the analysis of the Afrodescendants' position in the Peruvian society over time and the consequent evolution of their language until the present day. 
The first period is characterized by the arrival of a number of black slaves and freedmen, who participated with the Spaniards in the many campaigns of invasion and conquest during the 16th and the 17th centuries (roughly 1530-1650). These people proceeded primarily from Spain and from other American colonies under Spanish control (e.g. the Caribbean); at that time, the number of bozales ${ }^{14}$ was quite reduced. The first blacks to enter the Andean territory were typically identified with the term ladinos ${ }^{15}$ which meant they had learned the Spanish customs, were Christians, and could speak Spanish fairly well. The second phase (1650-1760) saw an increase in the number of bozales introduced in Peru. They were primarily used in urban centers as domestic servants or skilled artisans and on coastal rural plantations as farmers. Lastly, the third phase (1760-1980) consisted of a gradual decline in African-born slave importations and a progressive acquisition of civil rights by Afro-Peruvians.

\subsection{Slavery in the Spanish world before and during the American conquest}

Before offering an analysis of black slavery in colonial Peru, it is fundamental to provide a brief account of the geopolitical situation that regulated slavery in the Spanish world before and during the American conquest.

During the fifteenth century, slaves could commonly be purchased in Spain. Some of them proceeded from the Caucasus and were brought into the region by Italian merchants; some were Moorish war prisoners, while others were blacks, generally captured in Africa and sold in the Peninsula by Arab traders (Watson 1989). In the 1450s, the Portuguese started breaking the Arabs' monopoly of trading in blacks since during the years they came in touch with new tribes along the Western coasts of Africa. By the 1460s, a considerable number of blacks had been introduced into Spain by the Portuguese. Some Spanish merchants tried to compete in this business with their Lusitanian neighbors, but after a few years of dispute, the Spanish Crown decided to cede the rights on the exploitation of the African mainland to Portugal in exchange for the Canary Islands. In 1493, one year after Columbus' 'discovery' of the Americas, by means of the papal bull Inter Caetera, Pope Alexander VI assigned to Spain the right of exploration of any territory discovered one hundred leagues west of the Cape Verde Islands.

14. A bozal was a slave born in Africa, not familiar with the Spanish language and customs.

15. A ladino was a slave born either in Spain or in the Americas, thus he could speak Spanish and was familiar with the Spanish traditions and lifestyle. 
However, a year later, the agreement was revised and the monarchs of Spain and Portugal (with the support of the Catholic Church) drew a new document - the Treaty of Tordesillas - which established that the subdivision of the 'New World' between Spain and Portugal would have been along a meridian 370 leagues west of the Cape Verde Islands, rather than just 100 leagues as previously stipulated (Bowser 1974:2). Portugal, in this way, obtained the exploitation rights of what would become Brazil, the non-interference of Spain in Africa, as well as the possibility of reaching India by circumnavigating the African continent. In return, Spain obtained the rights to the rest of the Americas. This deal definitively formalized the non-intervention of Spain in the colonization of Africa and, therefore, its subsequent incapacity of directly providing its American colonies with black slaves.

In 1526, Charles V, the King of Spain, prohibited the enslavement of Indians, even in the case of war prisoners; the only exceptions that were made to this regulation happened in 1564-1569 for the Caribs, and in 1607 for the Indians of Chile, since these two native groups were considered extraordinarily aggressive (Andrés-Gallego 2005). Since Spain did not have its own African colonies; the Kings granted asientos 'trading licenses' to several foreign companies to supply Spanish America with black slaves. During most of the 16th century, asientos were assigned to a variety of Italian, Spanish and Dutch merchants. However, due to the subsequent union of the Spanish and Portuguese royal families, from 1580 to 1640 asientos came to be systematically assigned to Portuguese slave traders, who could directly import Africans from their enslaving forts along the Western African coast. In 1640, after the Portuguese declaration of independence from Spain, the Crown started reducing the employment of Portuguese traders, at the same time, it began to rely more and more on the French, the English, and the Dutch. From 1701 to 1711 the French Royal Guinea Company predominated in the business, which then passed to the English South Sea Company for the following thirty years, and then eventually to Dutch traders (Bourne 1904:269-281; Colmenares 1997:34).

\subsection{Conquest and colonization (1530-1650)}

Slavery had been present in Spain since Roman times, and when the Spaniards 'discovered' the Americas, they took this institution with them. Since the beginning of the Peruvian colonization, in the first decades of the 16th century, the Spanish conquerors brought with them a considerable number of black slaves, who were used as soldiers in the many campaigns of exploration and settlement. According to Torres Saldamando (1900:409): 
El primer negro que pisó tierra peruana fue el que en 1526 desembarcó en Tumbes con Alonso de Molina cuando fue reconocido este puerto por los de Pizarro. (The first black person who entered Peru disembarked at Tumbes with Alonso de Molina when that port was reconnoitered by Pizarro's men).

What is also commonly reported about the Spanish arrival to Tumbes is that when the local Indians saw this black soldier, they were amazed by the color of his skin; they could not believe it and tried to wash it away by vigorously scrubbing what they thought to be dye on his body (Helps 1900:310; Bowser 1974:4).

These first blacks to enter the Andean region were usually Christians, who could speak Spanish, and had a good understanding of Spanish customs. They were typically born in the Iberian Peninsula or, if they were born in Africa, they had generally spent some time with their masters in Spain or in already settled Latin American colonies, so that they were for the most part ladinos (Bowser 1974:3).

The Spanish Crown controlled a monopoly on slave trading to its colonies. As a result, this business was highly constrained. In fact, the Crown granted only a limited number of asientos to few trading companies. Moreover, for each slave transaction, it charged almorjarifazgos 'import taxes' and alcabalas 'sales taxes'. Such a strict regulation played an important role in limiting the introduction of Africans into Spanish America. This kept the ratio between the black and white populations relatively low in several colonies (see for example Díaz-Campos \& Clements 2008 for Venezuela; Sessarego 2011a, 2013d for Bolivia and Ecuador; and Clements 2009:68-101 for Cuba).

In the early reports of the conquest of Peru, black servants appear on several occasions. Soon after discovering Tumbes, Pizarro returned to Spain to seek military and financial support for his conquering enterprise. In 1529, he was granted royal support and, among other things, he received fifty-two black slaves free from duty charges (Bowser 1974:4). Several other conquerors and settlers were given similar permissions to import a certain number of blacks. According to Bowser (1974), between 1529 and 1537 the Kings released at least 363 import licenses, of which 258 were given to Pizarro and his relatives.

Even though blacks were active participants in the invasion and colonization of the Americas, observers of the time rarely report their proper names in these military adventures; they often are just classified as negros 'blacks', thus generalizing their identity and depriving them of personality. Restall (2000: 184) analyzes Pedro de Cieza de León's mid-sixteenth century description of the conquest of Peru. He shows that Afrodescendants are mentioned in this historical account thirteen times for the Peruvian campaign and six times for the Chilean one; however, in none of these missions are blacks called by name. The author $(2000: 174,184)$, nevertheless, was able to trace back the identities of three of these black men. These soldiers were called Juan García, Juan Valiente, and Miguel Ruiz (cf. 


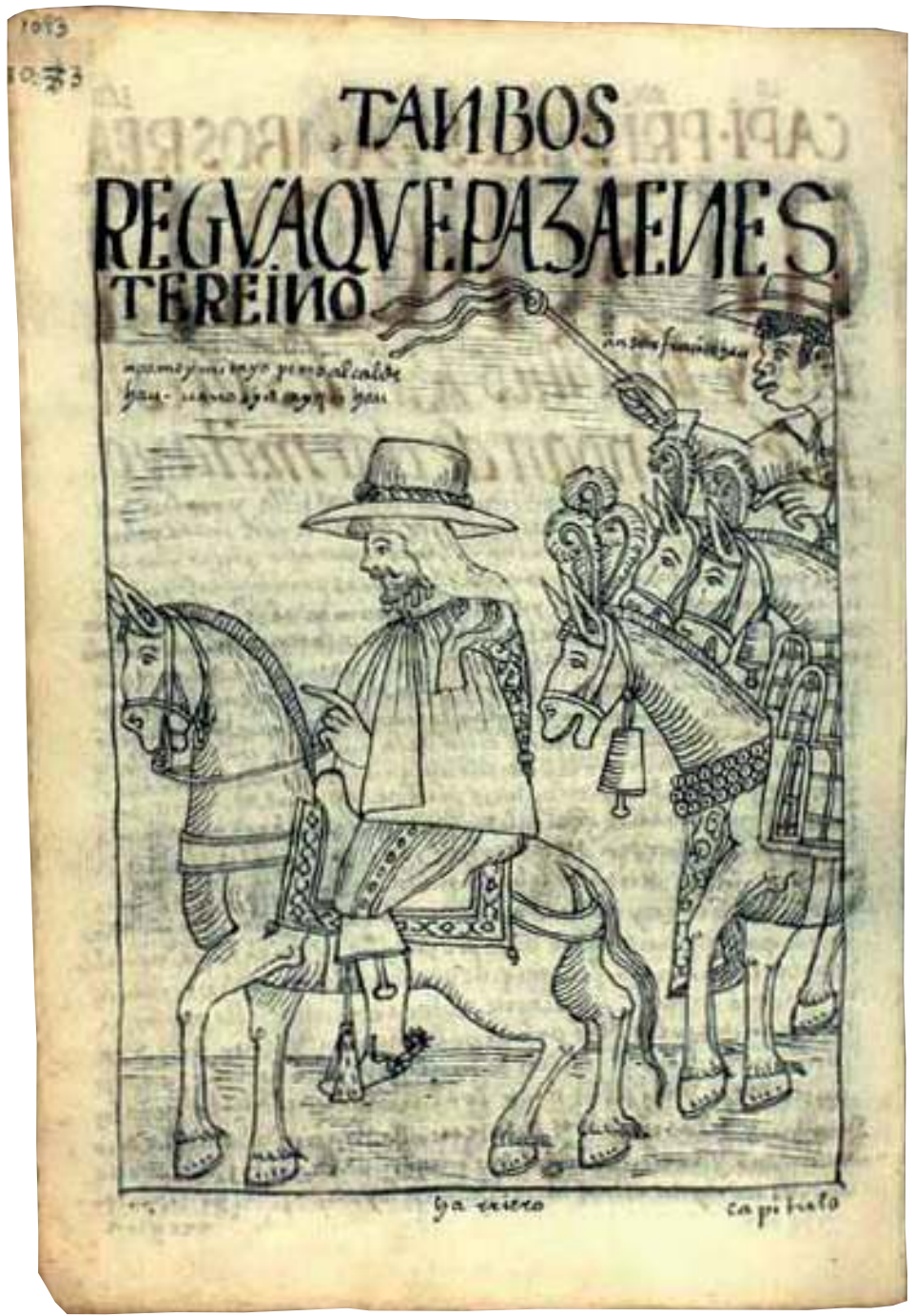

Figure 5.1 A Spanish conquistador with his black servant (Guman Poma de Ayala 1615)

Lockhart 1968: 6-15, 380-384; Cook \& Cook 1998: 243; Boyd-Bowman 1968: 134151; Sater 1974:16-17). Restall was able to reconstruct the biographies of two of them. I report this information here, since I believe it can provide us with important insights about the lives of the first blacks who entered the region, as well as about the language that they were likely to use (see Table 5.1 and Table 5.2).

The data reported for Juan García and Juan Valiente appear to support the claim that the first blacks involved in the colonization and settlement of the Andean region were probably ladinos who were born in the Iberian Peninsula or 
Table 5.1 Biography of Juan García (Restall 2000: 186)

c. 1495? Born free, near Jaraicejo (near Trujillo, Extremadura), probably of mixed blackSpanish parentage though later referred to by other Spaniards as "black".

1530 Recruited in Trujillo to join Pizarro expedition to conquest to Peru; leaves behind a wife and two daughters.

1531-34 Footman member of Pizarro-led expedition of conquest that leaves Panama in January 1531; holds the posts of crier (pregonero) and piper (gaitero) and is made responsible for weighing gold and silver at Cajamarca; present at the division of gold and silver at Coaque in 1531, at Cajamarca in 1533 (where he buys an enslaved native Nicaraguan woman from a fellow conquistador), and at Cuzco in 1534.

1534-35 One of the founding citizens of Spanish Cuzco, where he then resides.

1535-36 Travels to Lima, where he spends time preparing his return to Spain, then to Nombre de Dios (Panama) and back to Extremadura; takes with him his share of gold and silver and probably his illegitimate daughter and her native Andean mother, one of his servants.

1536-45 Lives in the Jaraicejo-Trujillo area to at least 1545, calling himself Juan García Pizarro; date of death unknown.

Table 5.2 Biography of Juan Valiente (Restall 2000: 187)

\section{c. 1505? Probably born in Africa.}

Pre-1533 Resident in Puebla (Mexico) as the slave of Alonso Valiente.

1533 Leaves Puebla, with written and notarized permission from his owner to join conquest campaigns as soldier for four years; travels to Guatemala.

1534 Joins Pedro de Alvarado's expedition from Guatemala to Peru; Alvarado is bought out by Diego de Almagro but Valiente stays in Peru.

1535 Member of Almagro's expedition to Chile.

1540 Member of Juan de Valvidia's expedition to Chile, as a vested partner with his own horse; gains title of captain.

1541 His legal owner in Puebla sends a nephew with power of attorney to sell Valiente his freedom; the nephew apparently never finds his uncle's conquistador slave.

1546 Granted an estate near Santiago de Chile.

Pre-1548 Married Juana de Valvidia, probably an ex-slave of the conqueror Valvidia.

1550 As governor, Valvidia grants Valiente an encomienda near Concepción; he commissions a royal official to negotiate his legal freedom in Peru or Mexico, but the official returns to Spain instead.

1553 Killed by native Andeans at the battle of Tucapel; his son inherits his encomienda. ${ }^{16}$

16. The Spanish Crown granted encomiendas to Spanish settlers in the Americas. An encomien$d a$ provided the colonists with the right to demand tribute and forced labor from the Indians living in the region. 
had at least spent some time in previously settled colonies before moving to the Andes. They were people the Spaniards could trust; they helped them in the colonization of the region and received precious metals or encomiendas as payment. These blacks could probably speak Spanish natively or a good second language variety of it.

In these early times, before the New Laws of 1542-1543, which established that Indians could not be reduced into slavery, some Central American natives were forcibly taken to Peru to work as servants. Even though these Indian slaves were not from the Andes, they could more easily blend in and socialize with the local populations than blacks. African descendants, in fact, have always been perceived by the natives as foreigners; they could not integrate easily in the local context and, for this reason, they often identified more with their masters than with the indigenous people. This situation led to a reciprocal hostility between the Indians and the Africans, which turned out to be greatly beneficial to the Spaniards - and also partially to the blacks. Bowser (1974:7) comments on the fact that blacks soon came to occupy an intermediate social position between the Spanish colonizers and the natives. Blacks were often used to repress Indian uprisings or to help local priests and corregidores de indios ${ }^{17}$ (see Figure 5.2); moreover, since they were expensive, they came to symbolize economic wealth and many Spaniards wanted to possess them as domestic servants to show economic status and acquire prestige in society (cf. Lockhart 1968: 181).

Over time, black slaves started being used for other jobs. In particular, they were put to work in the construction of streets, churches and other public infrastructures. Those who had specific working skills were oftentimes exploited for a variety of commercial purposes that would provide their masters with good revenues (cf. Bowser 1974: 125-146).

Recent analyses of slave demographics have shed further light on the kinds of blacks who were introduced into Peru in this early colonial phase. Restall (2000:190-191) reports the comments of one royal official, Alonso López de Cerrato, who wrote to the Crown about how many Spaniards in the Caribbean "made a living by buying Africans [bozales], teaching them some trade [alguna industria] and then selling them at a profit on the mainland" (cf. Aguirre Beltrán 1946:20).

Bowser (1974:355 fn. 12) further supports the claim that the majority of the blacks found in Peru before 1560 were neither from Spain nor from Africa; rather

17. Corregidores 'correctors' from corregir 'to correct': Spanish public officers who had legal power over Indian communities. 


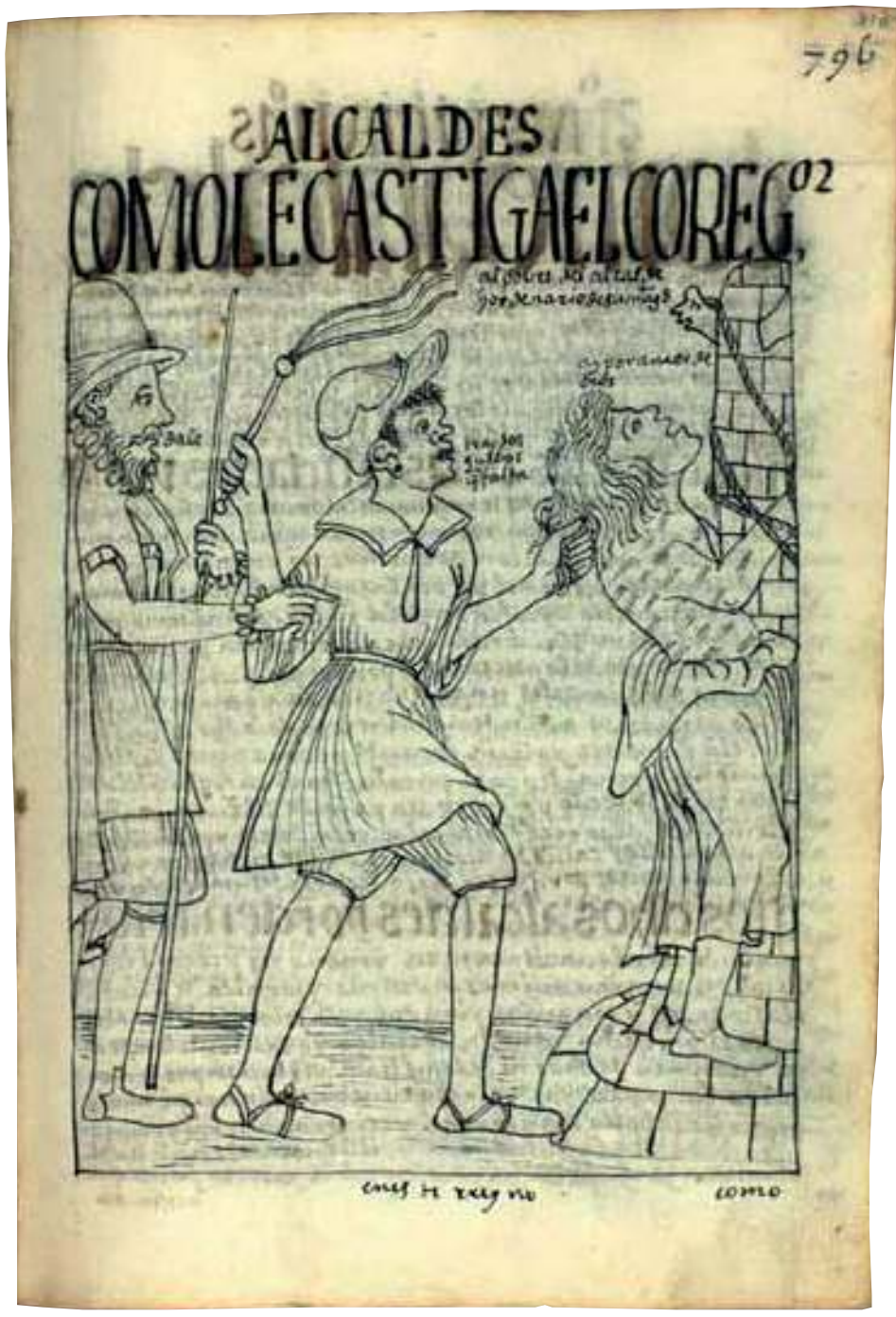

Figure 5.2 A black servant helping a Spanish corregidor de indios punish a native (Guman Poma de Ayala 1615)

they were probably Spanish speaking ladinos from already settled colonies (in partial contrast to what previously suggested by Lockhart 1968:171-198): ${ }^{18}$

18. This claim goes against what indicated by Lockhart (1968:173-175), who argues that the majority of the early arrivals were probably bozales who, however, would learn Spanish quickly because of their reduced number and their strong dependency on the Spaniards. 
It would have been perfectly logical for black slaves whose surnames identified their African origin to have been taken from (say) Hispaniola and to have served there for a number of years before coming to Peru [...]. The ladinos may well have preserved the surname that indicated African birth, but this does not prove direct importation from that continent to Peru or any other colony.

Further, it is difficult to believe that the volume of the slave trade between Africa and Peru before 1560 was sufficiently high to have made bozales preponderant in the colony. My own sampling of slaves sold in Lima during 1560-1562 show a total of 70 bozales among 276 blacks offered for sale; the sample for 15641566 yields 23 bozales out of a total of 239 slaves. By this date, of course (and as Lockhart indicates), a generation of Peruvian-born blacks would have reached salable age, perhaps reducing a still-modest demand for slaves and therefore momentarily cutting direct importation from Africa.

For the years 1560-1650, Bowser (1974:72-73) indicates that the majority of the slaves entering the colony did not proceed directly from Africa; rather they were mainly imported from Spain and/or the Caribbean, where they had resided for some time with their masters and had learned the Spanish ways. He reports data for a sample of 444 slaves sold in Lima between 1560-1650, the only true bozales - in his view - are those reported as proceeding from Tierra Firme (current Panama).

The journey that black captives had to go through to reach Peru was extremely strenuous. Slaves were imported from Africa and from the Iberian Peninsula. They were shipped to the port of Cartagena, on the Caribbean coast of Colombia. From there, they were taken to the Caribbean side of the Isthmus of Panama. After crossing the isthmus, they were shipped again to the ports of Piura and Callao, and then resold and distributed in the Peruvian region. Another route that became common from 1605 was from Buenos Aires. In this case, slaves arrived directly to Argentina from Africa and Brazil, they were taken through the Río de la Plata region to the Chilean coast, and then from there shipped to Callao (cf. Mellafe 1959; Romero 1987:82). This second route was illegal and thus free from royal duties; merchants managed to introduce slaves from Argentina and Chile by corrupting local government officials (cf. Studer 1958: 87-100). Several government attempts were made to eliminate this traffic; for example, in 1646 an official Chilean law forbade slave trade to Peru; however, the business seems to have continued during most of the seventeenth century.

Importing Africans into Peru was a complicated and risky job. Due to the strenuous journey, many casualties occurred among the enslaved population. These difficulties inevitably resulted in higher costs for the Peruvian buyers. If the price of a slave in Cartagena and Buenos Aires in the 17th century was 200-240 pesos (Colmenares 1997; Brockington 2006), in Lima the same slave could be sold 
Table 5.3 Countries of origin of a sample of slaves sold in Lima (1560-1650) (Bowser 1974:73)

\begin{tabular}{lc}
\hline Area & Number of slaves \\
\hline Spain (esp. Sevilla) & 97 \\
Tierra Firme Panama & 75 \\
Hispaniola & 60 \\
New Granada (esp. Cartagena) & 50 \\
Portugal & 45 \\
Mexico & 41 \\
Chile & 25 \\
Ecuador & 17 \\
Puerto Rico & 10 \\
Guatemala & 7 \\
Nicaragua & 5 \\
Cuba & 5 \\
Bolivia (upper Peru) & 4 \\
Venezuela & 2 \\
Honduras, Jamaica, Paraguay, Tucumán (Argentina), and Brazil & 1 \\
Total & 444 \\
\hline
\end{tabular}

for 500-600 (Bowser 1974). Owning slaves in the Andes was perceived as a sign of social and economic power, it represented an ostentation of wealth (cf. Crespo 1995). Since black slaves were expensive, Spanish businessmen tended to rely as much as possible on the Indian workforce. The natives could not be enslaved, but encomienderos could demand forced working duties to those living on their lands through a system called mit'a. The mit'a was a pre-Columbian working system used by the Incas. According to the mit'a, each man from a given native community had to work for a certain period of time on a given task. This was a rotational system, which implied that periodically different groups of Indians would be required to take on certain working duties.

Bozales proceeded mainly from Western Africa; in particular, from Guinea and later also from Angola. Some came from other regions, such as Congo and Biafra (Bowser 1974:42-43). According to Lockhart (1968:173), the following African ethnic groups were the most common during the first decades of colonization: Wolof, Biafra, Bran, Berbrsi, Mandinga, Terranova and Congo. Bowser analyzes the period 1560-1650 and provides this list of ethnicities: Angola, Bran, Biafra, Bañol, Folupo, Mandinga and Bioho (1974:42-43) (see also Aguirre 2005:26).

Slaves were shipped to Peru in small groups during this period. Records of the time show that between Panama and Peru, especially in the early decades of 


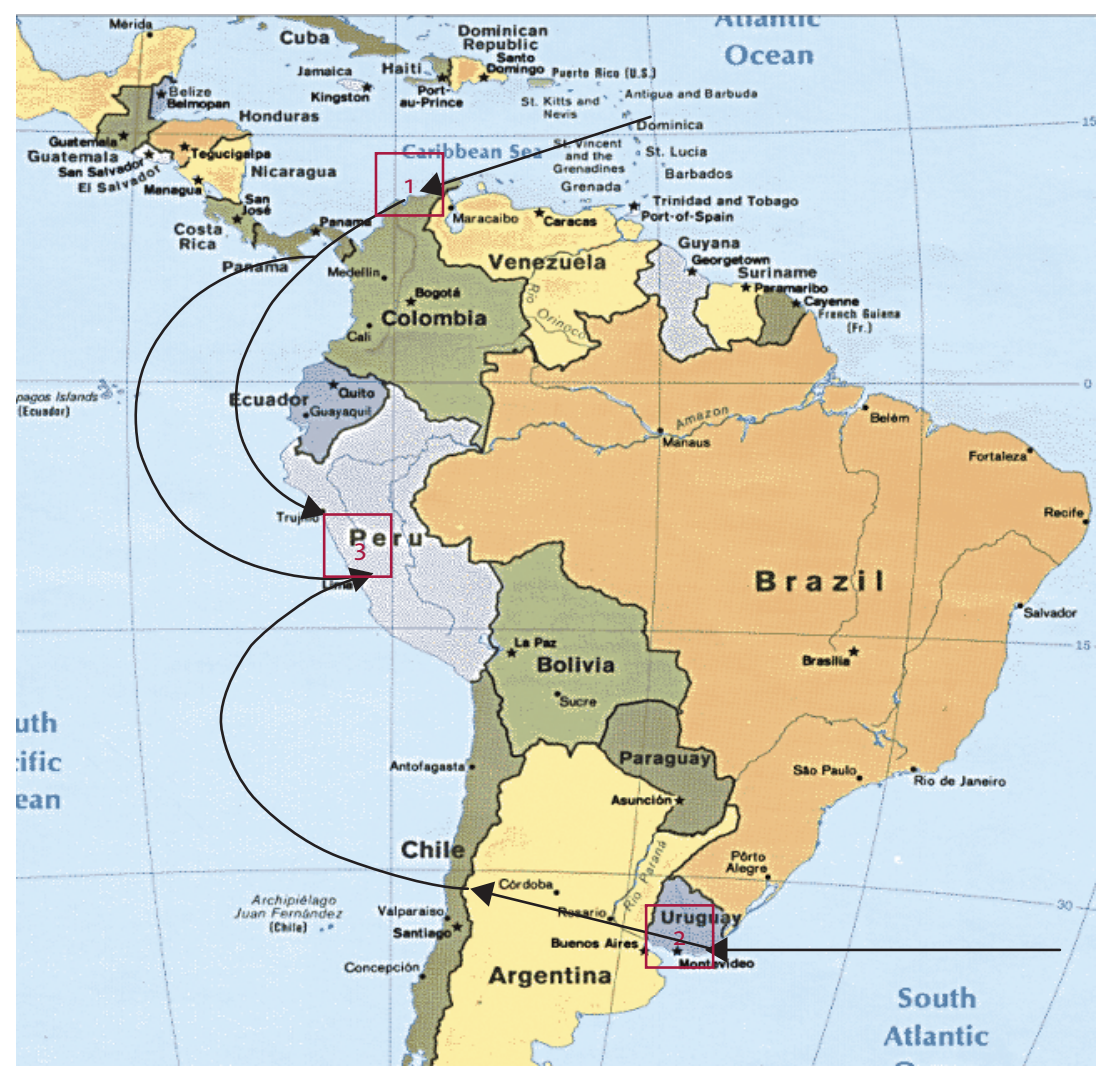

1 Cartagena 2 Buenos Aires 3 Callao (Lima)

Figure 5.3 Slave trade routes to Peru

(adapted from <http://www.lib.utexas.edu/maps/americas/latin_america.gif $>$ )

colonization (1530-1560), there was not an established business route. Indeed, in these early days, blacks came with their permanent owners, or sometimes with some merchants that would take a couple of them at a time along with other commercial items. Data confirm that the largest cargoes would import at most ten or twenty slaves at a time (Lockhart 1968:177), and that slaves used to be sold in small transactions; usually sales of one at a time, and more sporadically of two or three (1968: 178).

Lockhart also tells us that buying and selling small numbers of slaves became a "conscious process of capital formation" (1968: 178). In fact, as reported by Racall for the case of the Caribbean, artisans would purchase untrained slaves, teach them a profession, and then sell them for a higher price. Lockhart (1968: 183) provides the example of a tailor shop in Lima in 1550, consisting of a Spanish master, 
four trained slaves and four other workers who were being trained (three blacks and one Indian). Another case is the one of a confectionary in 1552, which included a Spanish confectioner, a trained slave and three other captives who were learning the profession.

Some of the jobs that black slaves did in urban centers like Lima were piper, gatekeeper, guardian, constable, auctioneer, executioner, master of weights and measures among others. However, the most common position held by Peruvian blacks was probably the job of crier (pregonero). Lockhart (1968:380) even stated on this specific point: "Spanish social conventions demanded that criers be black or mulatto".

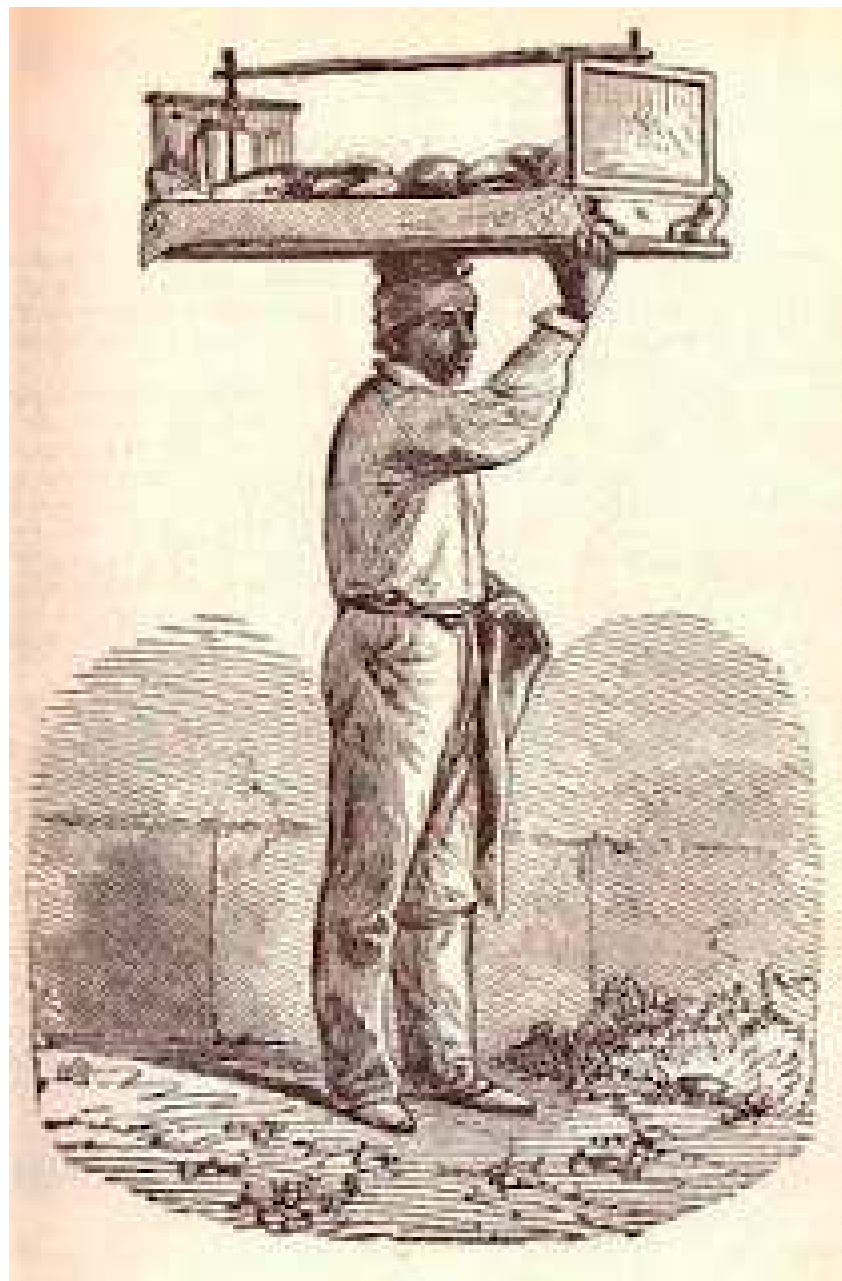

Figure 5.4 A pregonero selling bread (Periodismo en el Perú 2012) 
Skilled slaves soon became very popular 'goods' among those who could afford them: not only Spaniards, but also Indians and Afro-descendants themselves. Skilled slaves would represent a fairly safe investment for their masters, since their work would provide a good influx of revenue. At the same time, black captives with a profession of this kind would be able to improve their social status over time. In fact, they would be able to keep some of the revenue for themselves and, therefore, they could purchase their freedom and eventually start their own business. ${ }^{19}$

In certain cases, black workers became so successful that white artisans felt their businesses were under threat. In more than one occasion, white citizens appealed to the local government to prevent blacks from running taverns, tailor shops, and carpentry shops, among other businesses; often they did that by recurring to the claim that Afro-descendants would cheat customers by providing them with lower quality services (Bowser 1974).

One of these successful black businesspeople was Catalina de Zorita, a free black who owned a bakery and a confectionery in Lima in the 1550s. Another case, probably one of the most successful ones, was Juan de Fregenal, a black person who obtained his freedom in 1547. In a few years, he became a prosperous businessman who purchased dilapidated properties, improved them, and sold them to make a profit. His real estate enterprise went so well that he collected enough capital to diversify its business and venture into agricultural commerce by buying lands in the proximity of Lima on which free and enslaved blacks would work for him (Lockhart 1968: 194-195).

The exact number of the blacks who entered the Peruvian region during this period is impossible to calculate. However, it has been estimated that between the 1530s and the 1540s, some 2000 Afro-descendants arrived with the Spanish invaders (Restall 2000: 183). Restall (2000: 185) also suggests that despite the mortality of the conquest and the civil war of the 1540s, the number kept growing in the following decades, so that by 1550s there were probably 3,000 blacks in this colony, with approximately 1,500 in Lima, the capital (cf. Bowser 1974: 11). Bowser indicates that this number was not a large figure but, at the same time, he admits that the Spanish population was probably not much larger.

The author also relies on a variety of archival demographic data for the city of Lima and traces the evolution of the capital's ethnic groups until 1640 (cf. Bowser 1974:337-341). He reports the 1593 census, which estimated the black/mulatto population to be 6,690 out of a total of 12,790 . He also offers the demographic figures for 1600, 1614, 1619 and 1636 (see Tables 5.4-5.7).

19. This is a key piece of information for understanding the dynamics of slave manumission in Spanish America vs. other European colonies. We will return to this point in Chapter 6. 
Table 5.4 Population demographics for Lima in 1600 (Bowser 1974:340)

\begin{tabular}{lrcr}
\hline Category & Men & Women & Total \\
\hline Spaniards & 3,949 & 3,244 & 7,193 \\
Blacks and mulattoes & 3,203 & 3,428 & 6,631 \\
Indians & 306 & 132 & 438 \\
Total & 7,458 & 6,804 & 14,262 \\
\hline
\end{tabular}

Table 5.5 Population demographics for Lima in 1614 (Bowser 1974:340)

\begin{tabular}{lrrr}
\hline Category & Men & Women & \multicolumn{1}{c}{ Total } \\
\hline Spaniards & 6,165 & 5,702 & 11,867 \\
Mestizos & 97 & 95 & 192 \\
Mulattoes & 326 & 418 & 744 \\
Blacks & 4,529 & 5,857 & 10,386 \\
Indians & 1,116 & 862 & 1,978 \\
Total & 12,233 & 12,934 & 25,167 \\
\hline
\end{tabular}

Table 5.6 Population demographics for Lima in 1619 (Bowser 1974:340)

\begin{tabular}{lrrr}
\hline Category & Men & Women & Total \\
\hline Spaniards/Mestizos & 5,728 & 3,978 & 9,706 \\
Mulattoes & 510 & 656 & 1,166 \\
Blacks & 6,135 & 5,862 & 11,997 \\
Indians & 755 & 651 & 1,406 \\
Total & 13,128 & 11,147 & 24,275 \\
\hline
\end{tabular}

Table 5.7 Population demographics for Lima in 1636 (Bowser 1974:341)

\begin{tabular}{lrrr}
\hline Category & Men & Women & Total \\
\hline Spaniards & 5,109 & 5,649 & 10,758 \\
Mestizos & 142 & 235 & 377 \\
Mulattoes & 276 & 585 & 861 \\
Blacks & 6,544 & 7,076 & 13,620 \\
Indians & 812 & 614 & 1,426 \\
Chinese & 22 & - & 22 \\
Total & 12,905 & 14,159 & 27,064 \\
\hline
\end{tabular}

The author highlights how the number of mulattoes and mestizos in these tables is 'impossibly low' (Bowser 1974:340) indicating that many people were probably trying to pass for Spaniards. In particular, if the censuses of 1619 and 
1636 are compared, the number of mulattoes seems to have shrunken. Nevertheless, this apparent decline in the mulato population was not real; rather, it was probably due to the attempt of the free colored population to avoid paying the tributes that the government had imposed on this group.

As Bowser suggests, by this time, Lima was the place with the highest black/ mulatto concentration in Peru, probably two-thirds of the whole Afro-descendant population in the colony lived there (1974:341). Data indicate that in Lima this group was probably as large as the Spanish/mestizo segment. However, we have to consider that mulattoes as well as mestizos could probably speak Spanish natively. ${ }^{20}$ Moreover, the group labeled as 'blacks' was for a good part composed of Iberian-born slaves, ladinos, and criollos, with true bozales making up only a limited percentage of this sector. It is therefore likely that Spanish would have been the main means of communication within the Afro-descendant community. In an urban setting like the city of Lima, where the nature of the jobs performed by slaves often implied interracial contact and, therefore, consequent language acquisition, the emergence and stabilization of a creole language as a potential means of interethnic communication was probably highly reduced.

Bowser argues that the number of free blacks increased steadily during this phase. This was due to the fact that manumission was a common practice. Slaves, by law, could purchase their own freedom; they were entitled to own private property, and could keep part of their revenue. These financial means allowed slaves to save money and manumit themselves over time. Additionally, masters would often concede manumission to female slaves with whom they were having love affairs (Bowser 1974:272-323). Usually, children born by interracial relations of this sort were manumitted at birth. Futhermore, many slaves were manumitted by their owners' testaments. In fact, it was relatively common practice for Spaniards to free the most trustworthy slaves in their last will, on condition that the slaves would have prayed and arranged periodic masses for the soul of their dead masters (Bryant 2005).

Due to the relative easiness of obtaining manumission in the Spanish system, the free Afro-descendant population of Peru progressively augmented. In 1576, the Crown attorney in Lima indicated, without reporting any statistics, that the free Afro sector of the population was large (Bowser 1974:23). A decade later, in 1687, Lima's taxation reports show that the number of free blacks in the capital achieved a significant number, nearly a quarter of the total Afro-Hispanic population (932 out of 4000), and probably even more, since many former slaves would avoid the census to try not to pay taxes (Bowser 1974:301).

20. Since a mulatto is a person with one white and one black parent, and a mestizo is a person with one white and one indigenous parent, it is likely that they grew up speaking Spanish. 
Apparently, this fast-growing free population had all the ambitions that Spaniards had: acquiring a house, creating a family, and owning material goods - including slaves (Lockhart 1968:192). Free blacks did all the jobs that slaves did, with the only difference that they would keep the wages for themselves. Lockart indicates that a regular wage for a free Afro-descendant could range from 50 to 150 pesos a year, similar to that of an unskilled Spaniard. Some free blacks even managed to acquire haciendas. Lockhart mentions the case of Carabaya where some successful blacks owned lands on which Indians were working as employees (1968: 192). In Lima, several blacks owned houses; some of them were also landlords. They rented out properties and loaned money, usually to other blacks but also to white people (Bowser 1974:272-323).

While blacks could be found in cities working as domestic servants, pregoneros, or in a variety of other skilled and less skilled jobs, in the rest of the country, excluding the coast, Afro-descendants were not commonly found. In fact, whenever possible, Spaniards relied on the native workforce, which was abundant and inexpensive in the early period of colonization. The mit'a was particularly strenuous on the natives. These harsh working conditions combined with the introduction into the region of European diseases caused the native Peruvian population to fall from 6,000,000 to 1,500,000 between 1525 and 1571 (Bowser 1974: 18). Bowser also estimates that by the end of 1540 s, ninety per cent of the native coastal population had probably died (approximately 1,000,000 individuals).

This compelled the Spanish settlers to force entire Indian communities from the cold highlands to the warmer coastal regions to work on plantations and thereby supply the nearby urban centers with crops. The forced movement of aboriginal workers from cold to warm regions further increased the number of casualties among the Indians. This fact pushed the Spanish King in 1563 to forbid the use of natives in regions with a climate different from the one they were used to. This regulation, however, passed unobserved for several years because not using the natives would have implied relying more heavily on Africans, who represented an expensive and risky investment.

Over time, nevertheless, blacks came to populate the warmer coasts and gradually complemented the Indian workforce on the plantations. The first documentation of a visible black workforce along the costal territory comes from 1560s, when slaves are mentioned in government reports (Bowser 1974:21). Lockhart suggests that blacks complemented Indian labor on small and medium-sized farms. Large-scale plantations employing black workers were not significant in the sixteenth century. The only case he could find of a significant use of a black workforce was for an estate in Nazca, where apparently some forty blacks were used (1968: 145). Keith (1976:70) describes the medium-sized farm in the proximity of Lima in 1574. It consisted of 190 acres cultivated with corn, beans and 
cereals. The author also mentions a vineyard, 124 pieces of livestock, three slaves and one house for the supervisor (cf. Aguirre 2005:50). Bowser (1974:88-89) reports that until the end of the sixteenth century the number of slaves in the agricultural sector was relatively low, and that the slave workforce was usually combined with other types of native workers: mitayos, ${ }^{21}$ yanaconas ${ }^{22}$ and forasteros. ${ }^{23}$

After 1580 the agricultural sector benefitted more significantly from an African labor force. Gradually, in order to respond to growing urban needs, agricultural commerce started relying more and more on bigger estates, where the black workforce progressively became predominant. Bowser provides a survey of the slaves used in agriculture in this period. He starts by describing the town of Trujillo and the surrounding area. The regional economy was mainly based on the production of sugar, wheat flour, and other crops; this business relied on both Indian and black labor. The city of Trujillo alone in 1604 had 1,073 blacks (121 were free), 1,021 Spaniards and 1,094 Indians. Bowser suggests that in the countryside blacks were probably even more numerous. Another costal town was Salta, with some seventy Spanish families using slaves in the livestock business. However, the highest concentration of coastal slaves was probably in the valleys outside Lima where "many Indians and blacks" (Bowser 1974:92) were used to produce fruit, corn, sugarcane and potatoes, among other agricultural products. An observer of the time described this region by saying that "on every farm they have a Negro village for the exploitation of the vineyards [...] every Negro costs at least 500 pesos" (Vázquez de Espinosa 1942: 28, cf. Bowser 1974: 92). Blacks were often employed in vineyard work; the Ica Valley relied on some 8,000-10,000 slaves for wine production in the early 1600s. Proceeding south along the coast, slaves could also be found working in vineyards in the proximity of Nazca and in the Valleys of Camaná and Vitor.

Finally, Bowser summarizes the analysis of this survey based on a sample of forty-one coastal haciendas. He states that even though in some regions the black inhabitants were numerous "the size of the slave population resident on most estates during this period was relatively modest and rarely exceeded forty slaves of all ages" (Bowser 1974:94). He provides the following table to show that "only three plantations had more than forty slaves, and only one of these more than 100" (Bowser 1974: 95).

These data appear to contradict McWhorter's interpretation of Bowser's report, since McWhorter (2000:37) states that "in the early 1600s, slave forces of

21. Indian subject to the mit'a system.

22. Tribute-paying Indians.

23. Indian enrolled for a certain local work, who originally proceeded from a different region. 
Table 5.8 Population demographics for Lima in 1636 (Bowser 1974:95)

\begin{tabular}{cccc}
\hline Number of slaves & Number of estates & Number of slaves & Number of estates \\
\hline $0-5$ & 3 & $21-25$ & 4 \\
$6-10$ & 8 & $26-30$ & 4 \\
$11-15$ & 6 & $31-35$ & 4 \\
$16-20$ & 7 & $36-40$ & 2 \\
\hline
\end{tabular}

Table 5.9 Demographic figures for the city of Potosí (Crespo 1995:28)

\begin{tabular}{lccc}
\hline Year & $\begin{array}{c}\text { Afro-descendant } \\
\text { population }\end{array}$ & Total population & $\begin{array}{c}\text { Afro-descendant } \\
\text { population (percentage) }\end{array}$ \\
\hline 1611 & 6,000 & 160,000 & $3.75 \%$ \\
1719 & 3,206 & 70,000 & $4.66 \%$ \\
1832 & 1,142 & 224,000 & $0.51 \%$ \\
\hline
\end{tabular}

more than 20 were typical, while some plantations had 40 or more slaves" (Bowser 1974: 89,94-95). Conversely, only three plantations had more than forty slaves, while, as Table 5.8 shows, the majority of the haciendas ( 24 out of 38 ) had in between zero and twenty captives.

While a black workforce - even if expensive - appeared to be suitable to the warmer coastal climate, the same cannot be said for the colder highland environment where Africans were likely to die. Indeed the few attempts to introduce blacks to the highlands systematically failed. The fact that Africans were not suitable to work at the high altitudes in a frigid climate is expressed in a current Peruvian idiomatic expression saying el gallinazo no canta en puna 'the black buzzard does not sing in the highlands' (Bowser 1974: 14).

For this reason, in 1578 it was decided that 14,248 Indian men every year would serve as mitayos in Potosí, the richest silver mine of the Americas. Since the local native population quickly shrunk, to achieve the labor force levels needed, people from surrounding regions as far as Cuzco and Tarija were forcibly relocated in the Potosí area. It is unlikely that within the mit'a system a creole language spoken by African slaves could have emerged, at least in the mining centers of the colony. Records of the time, in fact, show that in such areas blacks were never a significant percentage of the population as shown by the figures reported in Table 5.9 (Crespo 1995:28).

In summary, the socio-historical information available for the period spanning from the early colonization of Peru (first decades of the 16th century) until 1650 does not seem to indicate that a fully-fledged creole language was likely to emerge amongst the Afro-descendent population of this region. In fact, logistic 
and economic restrictions did not allow for the massive introduction of Africans into the colony; rather, their introduction happened gradually - blacks were usually ladinos proceeding from Spain or other settled colonies, and masters usually acquired one or two slaves at a time (Lockhart 1968). Overall, it has been noted that the locally-born Afro-population grew steadily during this phase (Bowser 1974). ${ }^{24}$

It has been observed that the two-thirds of the black population resided in Lima, where they were often performing skilled jobs and had opportunities to improve their social status. Moreover, manumission was quite common, such that many blacks were free. A limited number of slaves were employed in the mines, while the remaining part was used on the coastal plantations, which were usually small and middle-sized. Working and living conditions on plantations were probably worse than in the urban setting; however, given that haciendas were usually of a small scale and the majority of the blacks introduced into the colony during this phase were not bozales (Bowser 1974), we may assume that the acquisition of Spanish might have been favored over the development of a stable creole language.

The aforementioned factors characterizing early Peruvian plantation settings are of fundamental importance for an understanding of the evolution of an AfroHispanic contact variety in the years to come. In fact, socio-historical data appear to suggest that with all likelihood the language spoken on these haciendas was not a creole but a variety relatively close to Spanish. This would have served as the primary target language for the following waves of slaves. According to the Founder Principle, in fact, a large proportion of the structure of today's contact languages was determined by the varieties of the founder populations (Mufwene 1996). The aforementioned socio-historical analysis, then, may already be seen as a robust factor that would reduce the possibility of a Spanish creole forming in colonial Peru.

\subsection{Second phase (1650-1776)}

During this second phase a concomitance of factors played an important role in constraining the use of black slaves in the colony. In particular, the Spanish Crown's monopoly on slave trading and the logistic barriers to introducing Africans into Peru implied that the local buyers had to pay a very high price to acquire

24. Schwegler (p.c.) agrees that this hypothesis seems reasonable. However, he points out the possibility that some slaves may already have arrived with knowledge/use of a creole, adopted in Cartagena (for instance). This situation might have been possible. Nevertheless, we do not really have any evidence supporting such a possibility, while all the sociohistorical and linguistic data available appear to suggest that a creole language was not spoken in Peru. 
black captives. As a result, in general, they could not afford to purchase slaves in big cargoes. Nevertheless, it has to be said that during this phase the use of blacks in the coastal region gradually increased, since the native population had been decimated in the region and had to be replaced by a new workforce (Flores Galindo 1984: Ch. 2).

While on coastal plantations the number of African slaves progressively increased during the seventeenth and eighteenth centuries, in the urban centers the black population gradually decreased. MacLean y Estenos (1947:30) and Centurión Vallejo (1954:3) show this reduction by reporting demographic figures for Lima's Afro-descendants. In 1614, Afro-descendants represented $40 \%$ of the total population; while, in 1720, they were $17 \%$. Apparently, the Afro-group continued to shrink during the eighteenth century, such that they were only $13 \%$ of the population by 1820 . This progressive reduction in the black urban population was partially due to the fact that black slaves were also gradually transferred from urban centers to more rural areas. In fact, throughout this phase of agricultural commercial growth, it made sense for slave owners in cities to employ their captives on rural haciendas or to rent them out to other planters. Indeed, black slaves, unlike Indigenous workers, were seen as piezas 'tokens' of "mobil capital" (cf. Bryant 2005:14,104), who could be transferred from one place to another without too much trouble. This piece of information is important for understanding what language variety might have been introduced on these early plantations. If a good part of the slaves were criollos, or bozales who had spent some time in urban centers, rather than captives proceeding directly from Africa, then the likelihood of a creole language forming on haciendas would have been quite reduced. ${ }^{25}$

During this second phase, the overall number of captives owned by slaveholders remained low. Viceroy Count of Monclova, who governed Peru from 1689 to 1705 , in 1700 calculated that $30 \%$ of Lima's nuclear families owned slaves. However, of these slaveholders, $70 \%$ had one to four slaves, while only $6 \%$ had more than ten (Jouve Martín 2003: 106). An analysis carried out by Flores Galindo (1984:123) about a collection of last wills drafted in the 1770s led to similar conclusions: $67 \%$ of the masters owned one slave, $23 \%$ had two, $10 \%$ possessed between six and twenty-one, while only six people had more than that (cf. Aguirre 2005:31).

25. Schwegler (p.c.) suggests that a creole language might have formed in a close-knit neighborhood of some urban centers and then be transplanted to some countryside hacienda. Again, as I stated in previous footnotes, in theory almost everything is possible; however, based on the available evidence we have, there is no likely way that such a situation might have actually occurred. 
The reason why Peruvian families did not usually own many slaves has to be found in their high price during the seventeenth and eighteenth centuries. Harth-Terré and Márquez Abanto (1961:19-20, cf. Aguirre 2005:32) indicate that a skilled slave could be easily sold for more than 1,000 pesos in Lima, while to purchase a cheap unskilled slave, the price ranged from 600 to 800 jornales, which approximately correspond to what a regular worker would make in two years of uninterrupted activity. The Royal Crown's monopoly on asientos also highly constrained the introduction of slaves during this phase. Even when the Crown decided to liberalize the business (in 1795), Peruvian citizens could not afford to buy several captives at a time. Flores Guzmán (2003:22) provides a breakdown of the slave transactions in Lima (the biggest Peruvian slave market) during the years 1770-1801 (see Figure 5.5). As can be noted, $76.9 \%$ of the transactions concerned one slave, while only $6.1 \%$ involved the purchase of more than five captives at a time. This suggests that even in this phase of agricultural expansion, the introduction of slaves into the colony was not massive, but rather for the most part it was highly constrained.

Slaves' urban life during this second phase did not differ much from before. They continued to be involved in several economic activities. At home, they were often employed as domestic servants; in particular, black women were commonly used as amas de leche 'wet nurses' (Arrelucea 2004:36). Slaves employed outside of home often carried out a variety of skilled and less-skilled works for their masters' economic benefit. During this period, they were often rented out on a daily basis to people in need of a labor force. This practice was called esclavitud a jornal (Aguirre 2005: 81). According to this working system, slaves were paid a certain amount of money for their daily work. Most of this income was for the master, while the remaining part was for the slaves themselves. Flores Galindo (1984: 122) reports the presence of 363 jornaleros in Lima in 1777; however, Aguirre (2005: 81)

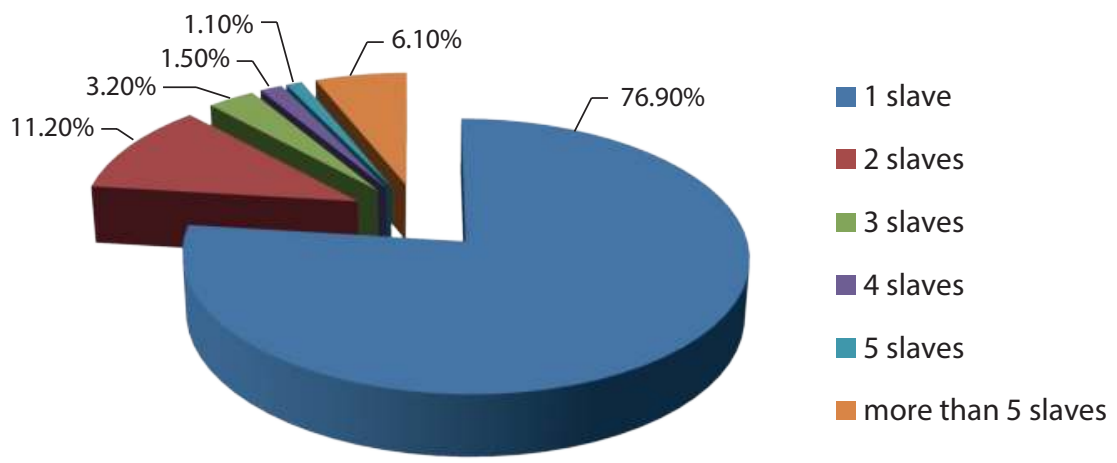

Figure 5.5 Slave purchases (1770-1801) (Flores Guzmán 2003:22) 
indicates that with all likelihood the number of jornaleros was significantly higher. As in the previous phase, urban slaves also performed a variety of other jobs: they were cooks, pregoneros, carpenters, tailors, street vendors, etc.

Some blacks even became successful students; especially in the fields of Medicine and Surgery. Apparently, a significant number of Afro-descendants managed to earn an education in these subjects, to the point that in 1737 a mulato applied for a position of professor of Medicine at the University of Lima, although his application was rejected by the Viceroy for racial reasons (Andrés-Gallego 2005: 128).

Andrés-Gallego (2005:208) points out that in Peru it was very common for urban slaves to recur to the protector de negros to sue their masters. The protector de negros was a lawyer who would assist blacks in courts without charging them any fees. In fact, in order to be able to adequately defend their rights during trials, a royal law of 1528 assigned a protector de negros to any black in need of legal assistance (Andrés-Gallego 2005:65). One such case is exemplified by the slave José de la Trinidad, who sued his master in Lima in 1765, because he made him work without rest to the point where he injured himself and lost a leg (2005:208). Another case is the one of the slave Domingo Barrueta, who took his master to trial because the latter wanted to move away from Lima and take Domingo with him. Domingo did not like this idea because he was married to a woman in Lima. Eventually, he managed to force his owner to sell him to another master in order to stay closer to his beloved (2005:211).

Andrés-Gallego even hypothesizes that, since judges were forced to listen to blacks' complaints by law, it could happen that in certain cases slaves sued their owners just to gain time off. He supports this claim by saying that, in fact, it was common for slaves to run away and then file a lawsuit against their masters for ill treatments. In this way, until the judge had made a decision on the case, slaves did not have to go back to work. This was apparently what master Don Julián de Aramburu said to the judges to defend himself when he was accused by two of his female slaves of mistreatment (2005:210).

Andrés-Gallego states that of all the legal cases he examined during the decade 1760-1770, the vast majority was favorable to the slaves' requests (2005:218219). Obviously, the lawsuits carried out by Afro-descendants were not always victorious. One instance of a loss is the case of a freed slave, María Josefa Olivares, who wanted to obtain freedom for her sons. However, since they were born before she achieved her own manumission, by law they were born into slavery; thus they could not be set free unless manumitted (2005:218).

Interracial sexual relations have always been common-practice in Spanish America, especially between white men and their black female domestic slaves. 
Aguirre (2005: Ch. 3) suggests that in many cases these relations led to manumissions. Manumission was also commonly obtained by means of coartación or as a masters' concession in their last will. Aguirre (2005:89) suggests that the free sector of the black urban population kept growing during the sixteenth and seventeenth centuries. While in 1586 they were almost one fourth of the Afrodescendants, and consisted of $10 \%$ of the total Lima's population; in 1792 they represented 20\% (Jacobsen 1974:84). A reason for such a relative increase is that many individuals by this time were born free. They were locally-born criollos, the descendants of former slaves, manumitted in previous generations. If we compare this information to the data about the overall size of the Afro-descendant group provided by MacLean y Estenos (1947) and Centurión Vallejo (1954), we can conclude that while the urban Afro-population was shrinking, its freed sector was growing.

While the percentage of black Limeños decreased, the black population living in the coastal region grew, but not massively and not in every hacienda. Due to the decline of the native population, the black workforce gradually came to complement and substitute the Indian laborers in the coastal valleys of Peru. Cushner (1980:82) suggests that "black slaves formed the bulk of the stable labor force from the middle of the seventeenth century on". However, it is important to state that even though there were some large haciendas in colonial Peru, "most slaves worked on medium-sized plantations of 20-50 slaves" (Aguirre 1997:501).

In the valley surrounding Lima, the eighteenth century saw a systematic shift from small-scale haciendas to medium and large-scale ones. For example, in 1773, out of 224 haciendas in the Caraballo, Magdalena, Surco, Pachacamac and Lurigancho valleys, 114 remained small properties (less than 60 fanegadas $^{26}$ ), 57 became medium properties (61-180 fanegadas), while 5 became large plantations (181-280 fanegadas) (Vegas de Cáceres 1999: 111-112; cf. Aguirre 2005: 52). Flores Galindo (1984:108-109) suggests that some of these haciendas employed hundreds of slaves; for example Villa had 400, while Bocanegra used 270. These cases, however were quite exceptional; a survey of Lima's valleys around 1837 reports that out of a total of 152 plantations, only four had more than 100 slaves, while 136 had no more than 20 (Aguirre 1993:53). Moreover, on those plantations, the working force was never completely composed of captives; rather, depending on the haciendas, a certain part of the workers consisted of free blacks, yanaconas, peones, and jornaleros (Aguirre 2005:71).

The shift to larger plantations was also partially driven by the fact that sugarcane could not be cultivated on small haciendas. Rather, it needed bigger lands

26. A unit of land measure that consists of 1.75 acres. 
to allow for the systematic rotation of the fields, typical of such a crop. During this period, in fact, sugarcane crops became more widespread due to the increasing demand for raw sugar and aguardiente $e^{27}$ in foreign markets (e.g. Panama and Chile). Sugarcane was difficult to grow and needed expert workers who could take care of such a high-maintenance job. Such workers had to be trained. Planters tended to prefer ladinos over bozales, since they could learn the job without too much trouble. After carrying out an analysis of the type of labor force employed in these early Peruvian sugarcane haciendas, historian Flores Galindo (1984:28) concludes:

La caña de azúcar llevó a la formación de algunas haciendas extensas, pero sobre todo hizo imperativo disponer de trabajadores estables. La siembra de la caña debía realizarse cuidadosamente [...]. Este proceso era imposible si no se disponía de una fuerza de trabajo, para los términos de la época, "calificada". Ante la escasez de población indígena en la costa y ante la imposibilidad de sujetar a los mestizos, la caña exigió el recurso a la fuerza de trabajo que podían proporcionar los esclavos. Dado el aprendizaje que requería el cultivo, se prefirió a los negros que conocían el español y estaban habituados a las costumbres del país: los "ladinos" en lugar de los "bozales".

(Sugarcane implied the formation of some larger haciendas, but in particular it made it necessary to employ stable workers. Sugarcane planting had to be done carefully $[. .$.$] . This process would have been impossible without a skilled work-$ force. Since the native population was shrinking in the coastal region and since it was impossible to convince whites or mestizos to carry out such work, sugarcane cultivation had to rely on the labor force that only the slaves could provide. Given the agricultural techniques that farming sugarcane implied, planters preferred to rely on the blacks who could speak Spanish and knew the Spanish ways, they preferred ladino slaves over bozales).

What Flores Galindo reveals in this paragraph is fundamental to understanding the type of language which was introduced on these early plantations. This suggests that the bases for the formation of a Spanish creole were probably lacking in these haciendas, since the workers who carried out the job could speak relatively advanced varieties of Spanish.

It was common for the slaves used on these plantations to receive a small lot of land on which to grow produce or to farm animals as a sort of personal revenue. These little properties were called chacras de esclavos 'slaves' fields'. Flores Galindo (1984: 110) and Aguirre (2005:68) mention the case of the slave Dionisia de Jesús, who had been assigned a chacra on La Huaca plantation where she farmed 200 chickens. Dionisia could sell the animals in the town market of Chancay and keep

27. Sugarcane liquor. 
the money she earned. Aguirre highlights the importance of these lots to slave families. In fact, slaves could improve their dietary intake by producing supplementary food and - most importantly - they could generate financial revenues to purchase their freedom over time.

Aguirre (2005:54) further highlights that even though the economic structure of the Peruvian coast during the colonial period experienced a gradual increase in the number of large properties, for the most part, it remained based on small and medium-sized businesses, which employed a limited number of slaves. In fact, only a few laymen had the material resources to develop large-scale agricultural commerce. The only organization that could really afford to rely on a considerable number of black slaves was the Catholic Church, in particular, the Company of Jesus. The Jesuits, in fact, became the largest slaveholder in the colony. By 1767, year of their expulsion from the Spanish territories, the Company of Jesus owned 5,224 black slaves in Peru. The majority of them worked on coastal sugarcane haciendas (62.3\%), almost one third was employed in vineyards (29.8\%), and the remaining slaves were used in highland farms (Macera 1966:36; cf. Aguirre 2005: 56).

Aguirre (2005:55-71), in fact, takes the Jesuit plantation as the prototypical example of how larger colonial haciendas might have looked. He relies primarily on Macera's (1966) and Cushner's (1980) accounts to show how the Jesuits ran this business.

Macera (1966) provides a detailed analysis of the Jesuit haciendas in Peru. He shows how the Jesuits were able to implement an enslaving system that, on the one hand, would provide the Company of Jesus with the most out of the captives' labor force, while on the other hand, it was able to make the blacks feel less exploited or mistreated. The goal, in fact, was to create among the captives a sense of community, so that no uprisings would take place. Macera (1966:38-39) states $^{28}$ that:

La importancia económica del esclavo determinó el desarrollo de una política por parte de sus amos tendiente a procurar el mayor rendimiento de la inversión. Los jesuitas fueron en esto verdaderos maestros y precursores pues se ingeniaron para aplicar normas demográficas, morales, de alimentación y trabajo que de un lado, les procuraba la lealtad del esclavo y de otro, les garantizaba la eficacia de su esfuerzo.

(The slave's economic value implied the development of a owner's strategy leading toward the maximization of the profit on the investment. The Jesuits were great masters in this matter and applied demographic, moral, feeding and working techniques that, on one hand, would provide the slave's loyalty while, on the other, they would ensure the efficiency of the effort).

28. See also Sotomayor Roggero \& Aranda de los Ríos (1979:9-10). 
As far as the demographic norms are concerned, the Company of Jesus did its best to support nuclear families and slave reproduction. For this reason, whenever possible, haciendas would have an almost equal number of males and females. This was seen as a key prerequisite to favor marital unions and thus increase the number of births (Macera 1966:39).

The Jesuits took very seriously the moral and religious side of their enterprise. Macera (1966:30) indicates that "La hacienda jesuita [...] estaba fundamentalmente al servicio de Dios y existían por tanto, al margen del negocio, ciertos deberes que cumplir" (The Jesuit hacienda [...] was working for God and, therefore, there were certain duties that had to be accomplished independently of the business activities). Jesuit haciendas, in fact, provided slaves with a variety of religious services, which were seen as fundamental to the Jesuit mission: bozales had to be catechized and instructed in the faith; weekly catechism had to be provided to children and adults; there were collective prayers, 10 masses for the death of each slave, religious celebrations (Easter, Christmas, etc.), confessions and communions, daily religious classes for the children, etc. (1966:30). As far as this last point is concerned, it is interesting to note one of the comments made by a Jesuit while writing a document concerning the administration of these haciendas in 1673 (1966:30):

Haya mucho cuidado de enseñar a los esclavos y a la gente de servicio que aquí hubiere la doctrina cristiana todos los sábados en la noche y a los muchachos y muchachas todos los días sin que en esto haya falta ninguna.

(It is crucial to teach the slaves and the other people working here that every Saturday night there will be a Christian celebration for them, while the children will have to attend it every single day, without any exception).

All these data certainly contradict McWhorter's (2000:37) claims regarding the fact that on Peruvian plantations "religion was withheld even to the point of denying slaves their last rites", at least for the haciendas run by the Company of Jesus, which was the biggest slaveholder in the country.

The great emphasis posed by the Jesuits on Christian education probably had significant linguistic repercussions on the means of communication developed on these plantations. In fact, religious instruction may have favored Spanish acquisition both as an L1 (for locally-born children) and as an L2 (for bozales). In particular, if young captives were taught into the faith every day from a very early age, they probably did not face many problems learning Spanish.

The Jesuits also tried to feed their slaves well enough to maintain labor efficiency. For this reason, the slave's diet was based on food with a high caloric content. It primarily consisted of corn and beans and, to a lesser extent, meat. 
Slaves were provided with tobacco and honey, and, during festivities, aguardiente (Macera 1966:45).

As far as the working schedule was concerned, slaves were provided with several days off (all Sundays and religious holidays), because the days dedicated to God could not be used to take care of wordly tasks (1966:30). A prototypical working day would usually last from 8 am to 5 or $6 \mathrm{pm}$, interrupted by a lunch break around noon.

Slaves were also generally provided with chacras de esclavos, where they could grow their own produce and farm their own animals. These pieces of land were given as awards to the well-behaved slaves, who could, in this way, enrich their dietary intake. In certain cases, these lots of land became so productive that slaves would sell their goods in the markets near the haciendas. Over time such a habit came to be perceived as a problem by many Jesuits, because it implied that slaves could leave the hacienda complex to take care of their business, thus providing captives with too much freedom and more chances to run away. Another complaint that certain Jesuits expressed was that in several haciendas slaves were not very productive since they would use their energies to work on their own chacras (1966: 45).

The information provided by Macera offers a picture of the Jesuit enterprise as a complex of haciendas where slaves' living and working conditions were probably not as harsh as those of black captives in other American colonies. The managerial activities implemented by the Company of Jesus, in particular their dedication to religious education, may have favored Spanish language acquisition; moreover, the fact that in certain cases slaves could travel to local markets to sell their own products indicates that at least certain captives were also exposed to the Spanish spoken outside of the plantation. All these elements appear to contradict McWhorter's claims on the nature of Peruvian plantations, which - in his view would have been well-suited for the development of a Spanish creole.

Cushner (1980:81-112) indicates that native mitayos and yanaconas were not commonly used on Jesuit coastal haciendas. On the other hand, the Company of Jesus relied mainly on black slaves, native jornaleros, and also some whites and mestizos, usually employed as skilled laborers and professionals. Regular peones received up to 40 pesos a year, skilled and professional workers were paid more; for example a mayordomo 'overseer' could earn 200-300 pesos yearly. During the seventeenth and eighteenth centuries the haciendas owned by the Company of Jesus grew both numerically and physically, so that a parallel increase in the employed labor force was needed.

Cushner (1980:95) suggests that the slave's dietary intake in these haciendas was relatively good. It was primarily based on vegetables, rice, and corn, with an average of seven portions of meat a month. The author indicates that during most 
of the sixteenth and seventeenth centuries, black populations were small in Jesuit haciendas and black families lived in crude huts; however, in the following years, due to an increase in the number of workers, dormitory-type accommodations substituted individual huts. This detail concerning the evolution of slave accommodations appears to be in line with what has been suggested by other authors who indicate a gradual - and never complete - shift from small and middle-sized farms to larger haciendas in certain coastal areas (cf. Bowser 1974; Aguirre 2005). If even the Company of Jesus, which apparently was the only organization with enough financial resources to rely significantly on an enslaved labor force, did not import African captives abruptly and massively, but rather, in a first phase it relied on smaller groups of slaves, then, it is likely that the vast majority of the Peruvian planters would not have either.

Cushner also provides records showing that in the eighteenth century married couples were living in units separated from the rest of the population. Preserving the familiar nuclei, in fact, had always been a priority on Jesuit plantations, so that families were never divided, and could develop a stronger connection to the hacienda (see also Brockington 2006 for Bolivia and Bouisson 1997 for Ecuador). Cushner (1980: 89) offers a demographic analysis of the evolution of the enslaved population on the eight biggest Jesuit plantations between 1665 and 1767 (see Table 5.10).

These eight big plantations experienced a significant increase in the enslaved workforce. They began with an average of 98.8 slaves each for the period 16651680; the haciendas increased steadily in the number of workers for the next 30 years, up until 1710 (174 slaves; net growth: +2.5 slaves per year). Subsequently the number of captives shrunk for the following 30 years, totaling 121 in 1740 ( -1.8 slaves per year); this decrease was probably due to a series of earthquakes and diseases that affected Peru during that period (cf. Cushner 1980; Andrien 1995). From 1740 to 1767 the enslaved labor force grew in size and achieved an average of 256 slaves per hacienda ( +5 slaves a year).

Table 5.10 Average growth of slave population in the eight major haciendas, 1665-1767 (Cushner 1980:89)

\begin{tabular}{lcc}
\hline Years & Slaves per hacienda & Net population growth per year \\
\hline $1665-1680$ & 98.8 & \\
$1680-1695$ & 139.6 & +2.7 \\
$1695-1710$ & 174.0 & +2.3 \\
$1710-1725$ & 129.0 & -3.0 \\
$1725-1740$ & 121.0 & -0.5 \\
$1740-1755$ & 217.7 & +6.4 \\
$1755-1767$ & 256.0 & +3.3 \\
\hline
\end{tabular}


Table 5.11 Slaves' births and deaths in four haciendas (Cushner 1980: 102)

\begin{tabular}{llcccc}
\hline Years & Haciendas & Slaves & Births & Deaths & $\begin{array}{c}\text { Net population } \\
\text { growth per year }\end{array}$ \\
\hline $1749-1778$ & Bocanegra & 245 & 374 & 324 & +1.7 \\
$1714-1775$ & Huaura & 253 & 410 & 574 & -2.7 \\
$1753-1775$ & La Huaca & 233 & 207 & 188 & +0.9 \\
$1759-1769$ & San Juan & 115 & 298 & 159 & +13.9 \\
& Totals & 846 & 1289 & 1245 & \\
\hline
\end{tabular}

Cushner (1980:101-110) analyzes the demographic data from the baptismal and burial records for black workers in the period 1714-1778 for the four biggest Jesuit coastal plantations; namely, Bocanegra, Huaura, La Huaca and San Juan totaling together some 1,200 slaves.

An analysis of the data indicates that overall the population increased, but not to a great extent (1,289 births vs. 1,245 deaths). The author suggests that part of the numerical increase in the enslaved working force in the years to come was driven by new purchases, rather than natural growth. Such considerations are certainly true; however, a closer look at the data presented by Cushner indicates that the introduction of slaves was not massive, not even for these haciendas that were selected for being the biggest and the most populated by slaves. In fact, in Table 5.11, three haciendas out of four (Bocanegra, La Huaca, San Juan) show a natural increase in the number of workers. The average is of +0.4 slaves per year. ${ }^{29}$ If we take out of the calculation San Juan, which has very high rates of natural birth (maybe due to miscalculations, cf. Cushner 1980:103), the overall average is $-0.8 .^{30}$ This range $(0.4 \sim-0.8)$ is perfectly in line with the trend reported in Table 5.10, which ranges from -3.0 to +6.4 slaves per year; thus it does not imply massive slave purchases. The only hacienda with a negative natural growth in Table 5.11 is Huaura ( -2.7 slaves per year). However, the period analyzed for this plantation spans from 1714 to 1775 ; thus it includes the phase of earthquakes and diseases that affected the colony (cf. Cushner 1980: 108). If we calculate the demographic trend of Table 5.10 for that period (years 1710-1767), we discover that the overall trend is $+1.4^{31}$ slaves per year. When we subtract the total yearly net growth $(+1.4)$ from the estimated natural growth $(-2.7)$, we get an idea of the number of slaves purchased every year per plantation during the 1710-1767 phase. Such a number is not massive but rather quite constrained ( +4.1 slaves per year).

\footnotetext{
29. $0.4=(1289-1245) /[(1778-1749)+(1775-1714)+(1775-1753)+(1769-1759)]$

30. $0.8=(991-1086) /[(1778-1749)+(1775-1714)+(1775-1753)]$

31. $1.4=(256.0-174.0) /(1767-1725)$
} 
What all these demographic considerations indicate is that, indeed, new slaves had to be introduced in these plantations to achieve the numerical growth obtained across the years 1665-1767; nevertheless, even for the biggest plantations in the colony, massive and abrupt importations of enslaved workers never took place. Rather, we see an average of at most +5 slaves per year, even during the most intense importation phase (1740-1767). Moreover, if we consider that with all likelihood not all the new slaves were bozales, but to a good extent they were probably locally born (cf. Flores Galindo 1984:28), then the chance of a creole language development was probably quite reduced. ${ }^{32}$

The relatively low natural population growth found on rural plantations appears to be in sharp contrast to what has been found for urban areas at the same time. Cushner (1980:102) reports that the Cercado Parish in Lima, during the years 1711-1770, registered 2,332 births and 1,187 deaths. In fact, we must keep in mind that even if during this phase the black urban population shrunk while the rural one grew, black slavery in Peru has always been a predominantly urban phenomenon, which, nevertheless, represented only a small sector of the whole Peruvian population.

Aguirre (1997:501) states that:

At any given moment [...] the number of slaves was only a small fraction of the population of the viceroyalty. In 1791 , for instance, there were only 40,347 slaves in Peru, representing 3.7 percent of the population. Of those slaves, 73.3 percent $(29,763)$ lived in the Lima administrative area, and most of them $(13,479)$ lived and worked in the capital, where they constituted about a quarter of the city's population.

Cushner indicates that no slave uprisings took place on Jesuit plantations during the eighteenth century. He attributes this to several factors: (1) disobedient slaves were quickly sold; (2) slaves usually did not form a coherent and organized group; rather, they were often divided into a hierarchical structure; (3) slaves were encouraged to create families; (4) slaves were taught in the Catholic faith; in particular, the Jesuits stressed the importance of hierarchical obedience. Slaves, in fact, were encouraged to believe that by obeying their masters they would have

32. Schwegler (p.c.) claims that a creole could have been introduced in this region form Cartagena and then transmitted from generation to generation as a means to preserve black identity. This is a valuable observation, which I cannot either prove or disprove. Based on the demographic and social data I could collect, I find it difficult to believe that a creole language, if introduced by some Cartagena slaves in these Peruvian haciendas, may have been passed on from generation to generation. In addition, it must be said that no traces of such a hypothetical language have ever been reported. 
followed God's direction and therefore "their reward for this would come in heaven" (Cushner 1980: 100).

It is true that the Jesuit management was family-oriented and incentivized local population growth; however, it must be said that working conditions on these plantations must have been quite demanding on the slaves, especially in sugarcane haciendas. Corporal punishment was often applied to the captives, even though there were clear limits: a certain number of lashes were seen as an acceptable punishment by the Jesuits, while harsher treatments (e.g. burning slaves with candles, etc.) were not permitted (Cushner 1980:89-90).

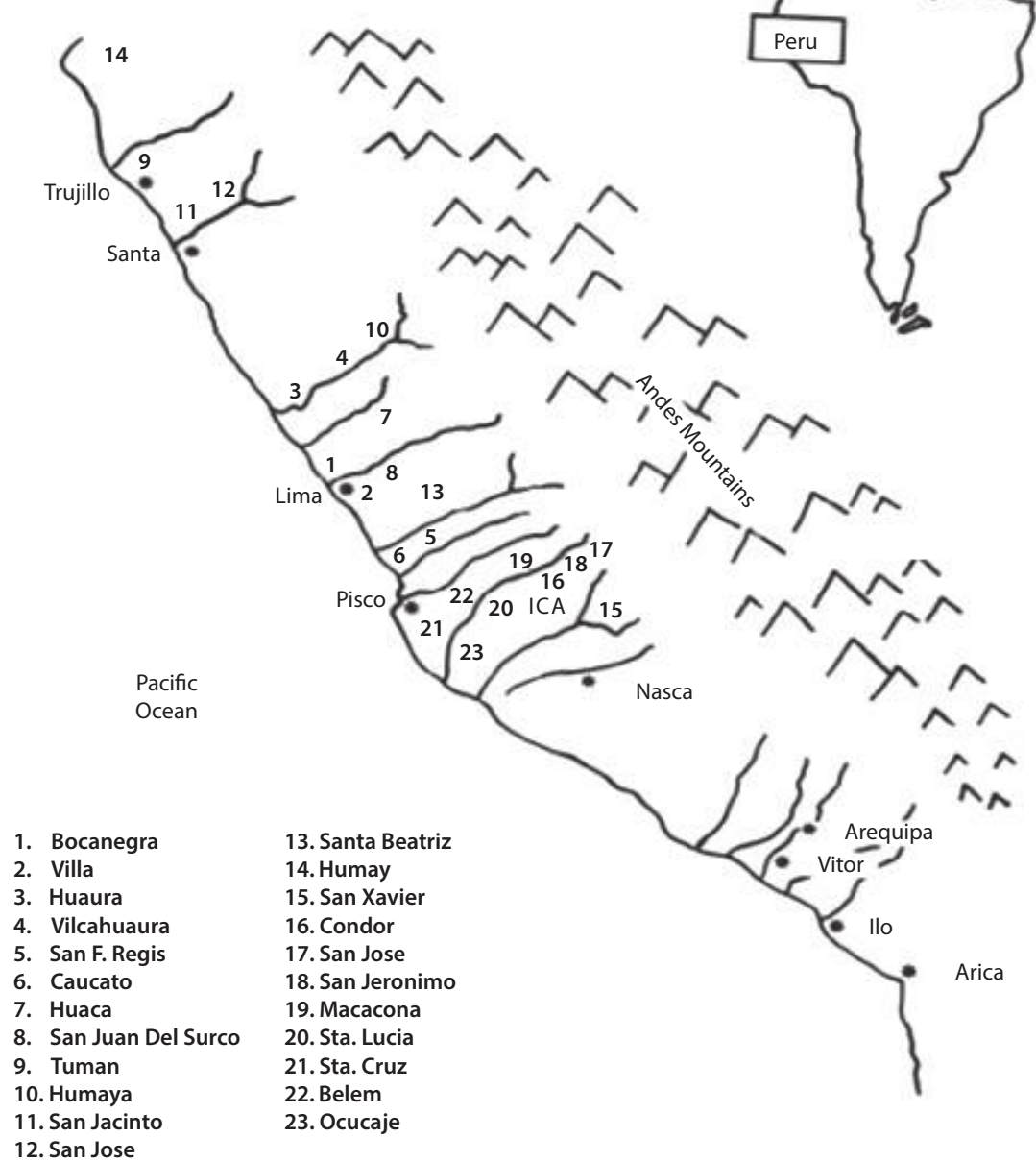

Figure 5.6 Jesuit haciendas in coastal Peru (Cushner 1980:ii) 
Unfortunately, after the Jesuits were expelled from the Spanish colonies in 1767, the lives of their slaves did not improve. Conversely, the Jesuit haciendas passed to the control of the Temporalidades council, the body in charge of selling the former properties of the Jesuits. Eventually, these lands (and their enslaved workforce) were acquired by private landlords, who frequently did not even bother preserving the integrity of black families and tried to sell family members individually, as tokens.

Aguirre (2005:151) reports the existence of several revolts that took place in the former Jesuit haciendas of San Jacinto and San José in Napena Valley in 1768. The reasons for these uprisings had to do with administrative changes introduced by the Temporalidades. The council, in fact, imposed harsher working conditions and wanted to take back from the slaves the lots of land that they were using as chacras de esclavos. Eventually, the revolts were suffocated by the government troops and the slaves responsible for them were punished.

In summary, the data encountered for the second phase (1650-1767) seem to suggest that the conditions for a creole language to develop in the colony were generally not in place. In fact, several geographic and financial factors appear to have limited the introduction of slaves in Peru so that their importation was never massive. Moreover, the presence in the country of thousands of other blacks, who arrived during the first phase (and their locally-born offspring), may be seen as an additional factor reducing the possibility of creole formation, in line with Mufwene's (1996) Founder Principle.

In the cities, where their living conditions often allowed slaves to obtain manumission and sometimes to succeed economically, the Afro-descendant population diminished, while the number of its freed members kept increasing. On the other hand, on the rural coastal plantations the number of slaves increased. However, the introduction of slaves happened gradually, with slave owners acquiring only a few slaves at a time (Flores Guzmán 2003). Aguirre (2005) also points out that the majority of the coastal haciendas were not large-scale plantations, but rather small and medium farms using only a limited number of blacks, usually combined with an Indian and Spanish workforce. The entrepreneurs who used the greatest number of slaves in their haciendas were the Jesuits, who, in some cases employed hundreds of them. However, some doubts must be cast on the possible evolution of a creole language on these plantations. In particular, this is the case if we consider that even in the largest haciendas the introduction of new slaves was neither abrupt nor massive (cf. Cushner 1980; Aguirre 2005), and that coastal planters generally preferred to rely on criollos rather than bozales for sugarcane cultivations (cf. Flores Galindo 1984).

Slaves' living conditions were probably less harsh in Peru, and in particular in Jesuit haciendas, than those of black captives in other plantation settings 
throughout the Americas. In fact, even if corporal punishment and strenuous labor were present on these plantations, the Company of Jesus was highly concerned with Christianizing the slaves and supporting nuclear families (Macera 1966). The managerial techniques used by this religious organization to achieve its objectives are likely to have favored the acquisition of Spanish by the black captives. The concomitance of all these factors contrasts with the hypothesis that depicts colonial coastal Peru as the perfect breeding ground for the formation of a Spanish creole (against McWhorter 2000).

\subsection{Third phase (1776-1970)}

After the departure of the Jesuits, uprisings similar to those mentioned above from Nepena Valley, where slaves wanted to re-establish the rights that they had acquired over time, became more and more common (Aguirre 2005: 154). Sala i Vila (1989:509-511) mentions similar cases for the Luya hacienda (Trujillo), in 1785, and for the Punat and Mollocope haciendas (Saña) in 1802 and 1811 respectively. Black slaves also took part in Túpac Amaru's revolt against the Spaniards. The indigenous leader, in fact, proclaimed blacks' freedom in 1780 and, in this way, enrolled in his armed group some Afro-descendants. However, since Túpac Amaru was defeated, Peruvian blacks remained slaves for several decades longer.

The war of independence between Peru and Spain provided Peruvian slaves with more promise of freedom. In 1816, Commander Bolívar proposed that any black who enrolled in the Independence Army would become a free man. Soon afterwards, General San Martín, the independence leader who supported Bolívar in Peru, proclaimed the same with the goal of enrolling as many people as possible in his army. Peru signed the abolition of slave trading in 1821. Moreover, in the same year, soon after the declaration of independence (15 July, 1821), San Martín implemented the libertad de vientres law, so that from that moment, any person born from an enslaved mother would be considered free (Sales 1974: 103). However, soon after the battle of Ayacucho (1824), which established the definitive independence of Peru, a set of regulations tried to constrain black freedom again. The most important action taken by the government in this direction was probably the Reglamiento Interior de las Haciendas de la Costa 'Coastal Haciendas' Internal Regulation' which guaranteed planters that slavery would not be abolished in the short term. In 1830, a law established that manumitted blacks would not become free until they were 21 years old, and in 1839 that age was postponed to 50 years (Aguirre 2005: 167). These pro-slavery regulations were lobbied by the landowners, who claimed that the elimination of slavery would cause a collapse in the agricultural commerce of the country. Landowners even managed to lift 
for a brief period the regulation sanctioning the abolition of slave trading, for this reason, in 1845, 500 slaves were introduced in the country from Colombia (Blanchard 1992:52-57).

Slaves responded to these new restrictive laws by trying to obtain their freedom by legal or illegal means. As for the first case, the number of self-purchased manumissions increased significantly, as well as the number of legal actions undertaken by the protectores de negros to sue slave owners (Trazegnies 1981; Lavallé 1999). In the second scenario, blacks oftentimes ran away from their masters and created bandit gangs to make a living (Aguirre 2005: 172).

Since slaves could not be imported any longer and the number of manumissions increased over time, the enslaved group shrunk during the nineteenth century. Aguirre $(1993: 47 ; 2005: 178)$ reports that in Lima the number of slaves was 12,263 in $1813,8,589$ in 1820, 7,922 in 1839 and 4,500 in 1845. A similar trend also took place in rural areas where some haciendas lost up to $70-80 \%$ of their enslaved black workforce during the same span of time.

In 1854, Ramón Castilla, who had served as president of the Republic during the years 1845-1851, started a revolution against the new government, run by José Rufino Echenique. At this point, in order to enroll soldiers in his army, Echenique proclaimed that any slave who joined his troops would become free. Soon afterwards, on December 3rd, 1854, Ramón Castilla declared all Afro-descendants free with only one condition: they should not serve in Rufino Echenique's army. At the same time, Castilla guaranteed slaveholders that they would receive government reimbursement for the lost value of the freed slaves. Castilla won and black slavery was abolished. However, once again, true freedom was not conceded to Peruvian blacks. In a law of January 1855, it was established that they had to forcibly work for their former owners for a minimal wage; a few months later, the government assigned to a group of planters the task of designing a set of rules to regulate the black workforce in the haciendas. According to observers of the time, the result of such a legislative effort was "worse than the recently abolished slavery system” (Távara 1855:34; cf. Aguirre 2005:187). At the same time, the government provided former slaveholders with 300 pesos for every manumitted slave. In this way, planters gained twice: they retained the price of the slaves and, at the same time, they could continue to rely on a cheap workforce. An additional advantage was that now they could decide whom to hire and on whom to fire, and they were relieved from taking care of sick or elderly blacks, who were no longer fit to work. Blacks who remained in these rural areas kept working for the haciendas belonging to their former masters until the Land Reform (1963-1979), which turned them into small landlords. Other slaves left the plantations to look for better working conditions in cities. They often ended up living in the poorest urban neighborhoods performing underpaid working-class jobs. 


\subsection{Sugar plantations in Chincha}

The socio-historical information so far provided does not seem to indicate that, overall, a creole language was likely to develop on Peruvian colonial plantations. This, however, does not exclude the possibility that in the Chincha region the situation might have been different. This section provides a socio-historical account of the plantation setting that characterized the Afro-communities examined in the present study (San José, San Regis, El Carmen and El Guayabo) to see to what extent a creole hypothesis might be feasible for them.

The earliest piece of documentation available for these villages belongs to the second phase (1650-1767), more precisely to the year 1688. It consists of a wedding act stating that Rosa Josepha de Muñatones y Aguado married Don Andrés de Salazar, bringing as her dowry the San José hacienda, including the village of El Guayabo, which was then turned into a sugar plantation with 87 slaves (CHSJ 2012:4).

We also know that, by the end of the century, the property was surrounded by Jesuit haciendas; one of which was San Regis, which was dedicated to the cultivation of sugarcane and wine production. Macera (1966:21), in fact, shows that the Jesuits began their agricultural enterprise in the region in 1692, when they acquired the first lands belonging to San Regis, and then kept increasing their properties by purchasing the nearby hacienda called Betlem in 1724, and Guachaqio in 1744.

San José was then sold in 1735 to Don Augustín de Salazar y Muñatones, the first count of Monte Blanco. During the 1760s, the Monte Blanco's property grew, since the family purchased the hacienda San Regis, which had been previously expropriated to the Jesuits, from the Temporalidades Council (CHSJ 2012:4).

Macera (1966:8-9) indicates that in 1767 the value of this Jesuit property amounted to $237,962.6$ pesos. The reason for such a high price had to do with the fact that the plantation included 1654 fanegadas, was of extension enorme $y$ excepcional 'huge and exceptional size' (1966:9), and included 302 slaves (1966:43). However, the author indicates that only 166 of the slaves were in the age range that would have allowed the full exploitation of their work (18-50 years of age), while 77 were too young ( $0-18$ years of age), and 55 were too old (more than 51 years of age). ${ }^{33}$

The presence of such a high number of young slaves suggests that they were probably locally-born. In fact, bozal children were not usually shipped to Peru since the strenuous journey from Africa would almost certainly kill them (cf.

33. There must have been some minor miscalculations in Macera's (1966) data. In fact, when we add all the numbers, we obtain a total of 298, which is 4 short of 302 . 
Sessarego 2013c: Ch. 2). Furthermore, the presence of a good number of old captives may suggest that slaves' life expectancy was quite long and, therefore, living conditions might not have been too harsh, as for example, in other plantations societies, where slaves would not usually live much longer than 30-35 years (cf. for example Migge 2003 for Suriname).

Another element that seems to suggest that living conditions on these Jesuit plantations were not as harsh as on other haciendas, is the fact that during the 18th century many slaves working on nearby farms would oftentimes run away from their owners to find shelter in the Jesuits' complex. Such a migratory flux ended when the Jesuits left in 1767, as Sotomayor Roggero \& Aranda de los Ríos (1984: 10) point out: ${ }^{34}$

Con la salida de los jesuitas San [Regis] dejó de ser un lugar en el cual buscaban refugio los esclavos que huían de las otras haciendas.

(When the Jesuits left, San Regis ceased to be the place where the slaves fleeing other haciendas would take refuge).

After the Jesuit departure, one of the places where slaves tried to hide from their masters would become El Carmen (CHSJ 2012:5). Flores Galindo (1984:108) also briefly reports the number of slaves encountered in San Regis during this period. His number matches the one indicated by Macera (1966:43): 302 slaves. Moreover, Flores Galindo re-states that this population, as well as the majority of the slaves introduced in coastal plantations, was likely composed of criollo captives (1984: 109):

Los grandes propietarios de la costa [...] preferían a los negros criollos: con ellos era más factible desarrollar los lazos paternales y, además, se podía esperar que estuvieran entrenados en cultivos tan laboriosos como la caña o tan delicados como la vid.

(The big coastal landlords preferred criollo blacks: with them it was easier to develop paternal connections, moreover, one could expect that they were more familiar with the sugarcane and winery cultivation, which required highly skilled labor).

This piece of information, in addition to the data provided by Macera (1966) concerning the religious indoctrination and the working and moving flexibility

34. The original quote states "San José" rather than "San Regis". This is because Sotomayor Roggero \& Aranda de los Ríos (1984) claim that San José belonged to the Jesuits after 1692 (cf. also Cuba 2002:18-19 on this point). Nevertheless, a close analysis of Macera's (1966:21) work, in addition to the data found in Boschetti (2006) and CHSJ (2012), appears to suggest that the Jesuits did not own San José; rather, they owned San Regis and rented their lands to the Monte Blanco family, which was already in possession of the nearby hacienda San José. 


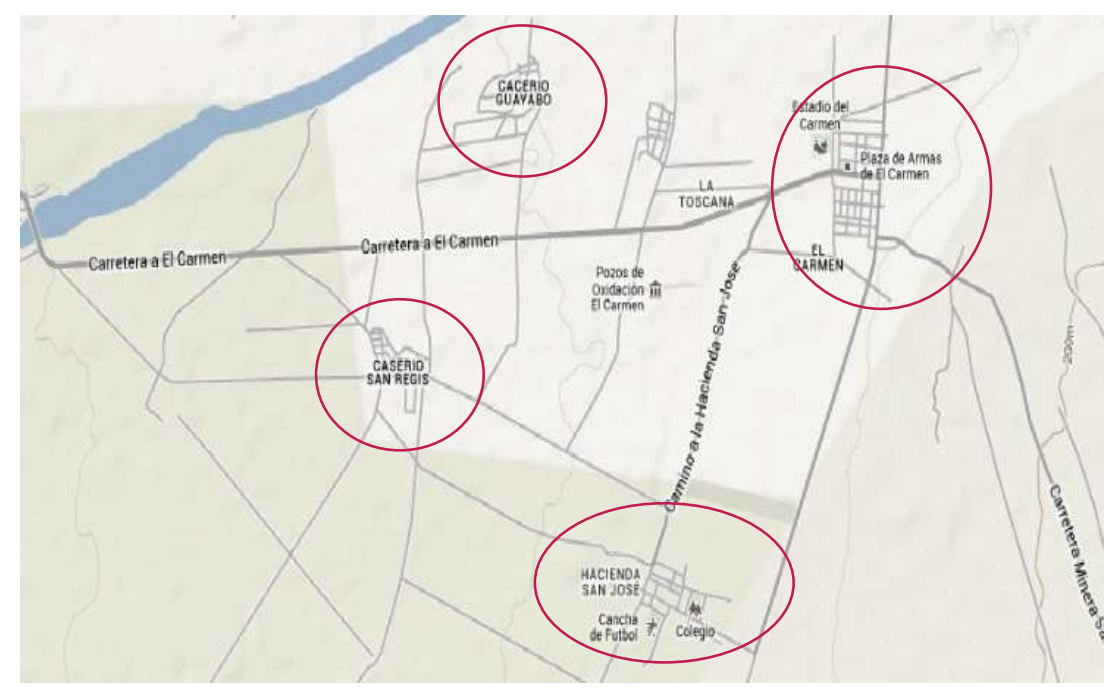

Figure 5.7 Overhead view of San Regis, San José, El Guayabo and El Carmen (adapted from: <https://www.google.com/maps/@-13.5047264,-76.0683455,15z>)

related to the chacras de esclavos (see Section 5.4), further reduces the likelihood of a creole language spoken in the region.

During the Peruvian War of Independence, in 1821, many of the slaves working on the plantations belonging to the Monte Blanco family ran away or joined San Martín's troops. The owner, Fernando Carrillo Albornoz y Salazar, fled to Spain, and his property was expropriated by the government. His wife, Petronilla Zavala, was able to recover the haciendas only in 1827 . Even though slavery had been officially abolished in 1854, in practice, the living conditions of hacienda workers did not change much. In fact, they kept working on the same plantations as unpaid peons (CHSJ 2012:5).

A few decades later, another war affected the haciendas belonging to the Monte Blanco dynasty. This time it was the War of the Pacific (1879-1883), which involved Bolivia, Peru and Chile. As soon as the war began, an uprising took place in the hacienda San José and the owner, Carrillo de Alboroz, was murdered. Soon after the tragic fact, his widow, Catalina del Valle y Osma, sold the hacienda to Roberto Legía, the Peruvian President's son, who resold it to Manuela Eguren de Cillóniz in 1913 (CHSJ 2012: 6; Sotomayor Roggero \& Aranda de los Ríos 1984). The new owners turned the hacienda into a cotton plantation and ran it until the 1960s, when the Agrarian Reform expropriated parts of their lands to give them to the black peones who had been working on them until that point (Boschetti 2006: Ch. 8). 
After the Land Reform (1963-1979), basic education and mobility reached almost all Afro-Peruvian communities, so that today many young Afro-Peruvians do not work any longer in the fields but prefer to study and move from the countryside to urban centers to look for better jobs. Nevertheless, Afro-Peruvians still constitute a highly discriminated minority, cut off from any position of power, whose members' standards of living are on average much lower than those of white and mestizo citizens.

Even though the socio-historical information provided in this chapter has shown that a creole language probably never developed in Chincha or in other Peruvian coastal regions, I agree with McWhorter's point (2000:39) that "something broader was at work" and that a case-by-case argument for each Afro-Hispanic dialect of the Americas seems to miss such a wider generalization. The goal of Chapter 6 is to offer a new socio-historical perspective - rooted in the comparative analysis of American slave laws - that draws a connection among these apparently "unconnected [...] constellations" (2000:39) of dialects. Therefore, while up to this point this study has primarily focused on Peru, in the following chapter I will propose a hypothesis that attempts to highlight some common patterns typical of all Spanish colonies in the Americas. This - I hope - will cast some new light on the Spanish creole debate and on the history of these mysterious "Missing Spanish creoles". 


\section{Solving the Spanish creole puzzle The legal hypothesis of creole genesis}

\subsection{Introduction}

As we have seen in this study, the Spanish creole debate is still much alive and certain Afro-Hispanic varieties such as APS may well be described as "Missing Spanish creoles" or "Decreolized Spanish creoles" depending on the hypothesis we adopt (Afrogenesis vs. Decreolization).

The socio-historical information provided in this book has shown that APS probably does not fit any of these models, but that it might be better described as and advanced conventionalized second language. This definition, I have argued, could probably be used to account for several other Afro-Hispanic contact varieties that present strikingly similar features. Indeed, recent studies on Barlovento Spanish (Venezuela) (Díaz-Campos \& Clements 2005, 2008), Afro-Yungueño Spanish (Bolivia) (Sessarego 2011a, b, 2013d, in press) and Chota Valley Spanish (Ecuador) (Sessarego 2013c) appear to lead to the same conclusion.

As far as the Venezuelan case is concerned, Díaz-Campos and Clements (2005, 2008) have shown that the linguistic features mentioned by Álvarez and Obediente (1998) in relation to a potential creole origin for Barlovento Spanish can also be found in a number of rural dialects, thus indicating that they should not necessarily be seen as creole indicators. Moreover, the authors have shown that, in contrast to McWhorter's (2000) predictions, colonial Barlovento was not the perfect place for creole formation. In particular, since the Spanish Crown's monopoly of the slave trade kept the blacks/whites ratio relatively low until the end of the 18th century, a plantation society did not develop in the colony. For this reason, the majority of the population classified by McWhorter as "Africans" were actually mixed-race people, who were born in the Americas and spoke Spanish natively.

In regards to Bolivia, Lipski claimed that "in absence of any other viable scenario, Afro-Yungueño Spanish must be viewed as the descendant of a colonial Afro-Hispanic pidgin" (2008:186), while Pérez-Inofuentes (in press) and Schwegler (2014) would link this dialect to a previous Portuguese creole stage. Nevertheless, a closer look at the linguistic features proposed as potential indicators of prior creolization indicates that the grammatical elements found in 
this Afro-Bolivian vernacular can be encountered in advanced second languages or non-standard Spanish dialects for which a creole hypothesis is not feasible. Moreover, the sociohistorical data analyzed do not suggest a creole origin either. Several factors have affected the dimension of African slavery in Bolivia and consequently the presence of black population in the territory from the 16th century through the middle of the 20th century. In fact, the Spanish Crown's monopoly of slave trading, the geographic location of Bolivia and the availability of native workforce affected the cost of Africans, raising their price and, as a result, reducing the number and the dimension of slave transactions. The non-massive introduction of black workforce into the territory favored the acquisition of a closer approximation to Spanish by the slaves (Sessarego 2011a, b, 2013d, in press).

Chota Valley Spanish (Ecuador) presents yet another case pointing to an advanced conventionalized second language as the most likely scenario (Sessarego 2013a, c, 2014b). On one hand, McWhorter (2000), proposes that colonial Chota would be one of the Latin American regions that supports his Afrogenesis Hypothesis since it was characterized by low whites/blacks ratio, harsh working conditions in labor intensive Jesuit sugarcane plantations, massive introduction of African-born workers, and minimal contact with the outside Spanish speaking world. On the other hand, Schwegler (1999) claims that also this dialect should be analyzed as the result of the decreolization of a previous Portuguese creole, since it would have retained the Portuguese pronoun ele 'he/she'. However, also in this case, African-born slaves have never been a majority group at any point in the history of the region (Coronel Feijóo 1991). In addition, sociohistorical reports from the Jesuit period (1680-1767) highlight a certain degree of social flexibility: the formation of nuclear families was favored, slave reproduction was high, each family was given a piece of land, and slaves could purchase their manumission (Bouisson 1997). Also, the claim that bozales were used massively to work these plantations is a bit problematic, since a concomitance of logistic and financial constraints strongly limited the introduction of Africans in the colony (Colmenares 1997). Contact with the outside world may not have been intense, however, Coronel Feijóo (1991) indicates that blacks could rent small land parcels to white people and sell agricultural goods in local markets. Finally, the Portuguese hypothesis appears to be contradicted by the fact that when the Jesuits started importing African workers to work in Chota Valley, Spanish colonies were no longer receiving slaves from the Portuguese; rather, they were acquiring them from French, Dutch and English traders (Colmenares 1997; Sessarego 2013a). From a linguistic perspective, the morphosyntactic features encountered in this dialect align with those reported for other Afro-Hispanic dialects in Chapter 5, thus they should not be taken as strong evidence in support of a creole hypothesis. As far as ele is concerned, data appear to suggest that we are dealing with at least 
two different elements: (a) a topic and (potentially) focus marker, which has been also described as an interjection to express emphasis, alarm, and surprise in a number of Highland (non-black) communities (cf. Córdova Âlvarez 1995; Lipski 2010); (b) a pronoun, which seems to be the result of a sporadic paragogic process of [e] insertion, since this phenomenon is also found in several other Chota Valley Spanish lexical items (ayer $\rightarrow$ ayere 'yesterday', ser $\rightarrow$ sere 'to be', etc.).

Faced with this evidence from a variety of Latin American colonies, we are left wondering if it is possible to find a common thread among all these colonial realities. We will address such an issue in this chapter. This chapter is in no way meant to provide a detailed analysis of all the complex factors that may have participated in shaping the Afro-European contact varieties currently spoken in the Americas; nevertheless, by relying on a comparative examination of American slave law, the current study aims to point out to the linguistic community some key elements that have been overlooked by previous theories attempting to account for the paucity of Spanish creoles in the Americas. Here I wish to offer a new perspective on the long-lasting Spanish creole debate.

A comparative analysis of slavery in the Americas will show that Spain not only diverged from other European powers in that it lacked slave forts in West Africa, as pointed out by McWhorter (2000); rather, one of the most prominent differences between Spain and the other countries involved in the colonization of the Americas had to do with the legal regulation of black captivity and, in particular, with the fact that Spanish slaves were the only ones who were granted legal personality. I call this hypothesis "The Legal Hypothesis of Creole Genesis". This hypothesis argues that the relative paucity of creole languages in Spanish Americas may be seen - in part - as the byproduct of differences in the European legal tradition; in particular, it has to do with differences in the reception of Roman law. In other words, my thesis claims that if England, the Netherlands, France and Portugal had adopted Roman slave laws ${ }^{35}$ to the extent that Spain did, then we would

35. It should be pointed out that in Roman law there did not exist any word similar to 'slave'. The Latin word was and is "servus", which became "serf" in English and in French and "servo" and "siervo" in Portuguese and Spanish. "Slave", in fact, is an adoption of the "tribal" name for Slavs. Slavs suffered attacks from neighboring peoples who used to sell them as serfs in markets around the Dead Sea, and so their ethnic name became a synonym of "serf". "Slave" is documented in Arabic in the 9th century and in Latin in 10th century (slavus, eslavus, esclavus...); so it is a late designation. Also, it must be acknowledged that the Siete Partidas never mention "esclavo" (slave in Spanish), but "siervo" (serf, from the Latin "servus"). Nevertheless, in the current study we will not focus on the historical evolution of these two terms (which ended up being used as synonyms in the Americas); rather, we will follow Watson's (1989) work and thus refer to "Roman slave law", "Spanish slave law", etc. We will do this for the sake of clarity, even 
probably not observe these disproportions between former Spanish colonies and other European colonies in the number of creoles spoken across the Americas.

The aspects of slave law most pertinent to this study are those that provide more insights into the nature of slaves' social conditions, their chances of climbing the social ladder as well as the access and incentives they might have had to learn the colonial language to improve their social status: the chances of becoming free people and the degree of acceptance of ex-captives into the free society; limitations on the masters' freedom to punish their slaves; the possibility for slaves to own property and accumulate capital; the right to have a family; and the extent to which the colonial administration regulated the public sphere of slavery.

\subsection{The Legal Hypothesis of Creole Genesis, a synopsis}

The Legal Hypothesis of Creole Genesis stresses the importance played by the different colonial legal regulations of slavery in the evolution of Afro-European contact varieties in the Americas. This work shows that one of the most prominent differences between Spain and the other countries involved in the colonization of the 'New World' had to do with the legal treatment of slaves. In fact, the legal figure of the slave was adopted by the Spanish system in ancient times, from the Roman Corpus Juris Civilis; it had been gradually changed into the medieval Spanish code, called Siete Partidas, and then further modified in the Leyes de India. On the contrary, such a legal figure followed a significantly different evolution in the other European legal systems, resulting in remarkably different socioeconomic and sociolinguistic outcomes in the European colonies overseas (Watson 1989; Andrés-Gallego 2005).

This section consists of a comparative analysis of slave law in the Americas. Findings indicate that black slavery in the 'New World' colonies was highly heterogeneous and that the Spanish system was the one providing slaves with the most rights. In particular, unlike the other legislations, the Spanish system was the only one that acknowledged legal personality for slaves. ${ }^{36}$ This element, as we will see, is key to understanding a series of rights enjoyed by Spanish slaves, which were completely absent in the slave regulations dictated by other colonial powers. This fact, I claim, is probably the most important factor to shed light on the

though it is understood that, from an etymological perspective, it would be more appropriate to talk about "Roman serf law", "Spanish serf law", etc.

36. The fact that slavery cannot be treated as a homogeneous phenomenon across space and time is particularly evident when we compare the Western colonial concept of it to the servitude system implemented in colonial times across Southeast Asia (cf. Ansaldo 2009: Ch. 2). 
Spanish creole debate and thus to understand the reasons behind such a "mysteriously absent creoles cluster under a single power" (McWhorter 2000:39).

The analysis presented in the current chapter is not concerned with all of the possible socio-economic and demographic factors that might have had an effect on shaping the Afro-Hispanic contact varieties that developed in the Americas (e.g. the effects of the Spanish Crown's monopoly on slave trading, logistic constraints on the introduction of African-born slaves, the economic structure of certain colonies, etc.; see Lipski 1993, 2005; Díaz-Campos \& Clements 2005, 2008; Clements 2009; Sessarego 2011b, 2013d, 2014a, b, c). Nevertheless, since a legal tradition is effective only if life conforms to it, in Section 6.3 I will try to bridge the gap between the idealized legal status of Spanish slaves and their social reality, while in Section 6.4 I will apply the hypothesis to three concrete case studies that represent challenging testing grounds for the model proposed: post-sugar-boom Cuba; seventeenth century South Carolina and Barbados; and eighteenth century Chocó (Colombia).

This proposal provides reasons to believe that the European legal tradition of slavery played a major role in American creole genesis and evolution. It also raises questions as to why the only two existing Spanish creoles in the Americas (Papiamentu and Palenquero) actually developed where no Spanish law ever applied: in The Dutch Antilles, and in San Basilio de Palenque, a formerly isolated maroon community in Colombia. ${ }^{37}$ Before describing slavery in the American colonies, I will provide an overview of Roman slave law, the legal system which, in one way or another, influenced the slave law of all the European powers involved in the colonization of the Americas.

\subsubsection{Roman slave law}

From a legal point of view, slaves in Rome were property; they had no rights, since they did not have legal status. In fact, to have legal status within a certain legal system implies acquiring a series of legal rights and duties, such as taking part in civil lawsuits, getting married, entering into contracts, etc. Slaves, however, were property of a special kind since, for certain purposes, they were treated as human beings. For example, they could be educated and could perform highly skilled jobs for the benefit of their masters. Moreover, they could be set free and, in that way, they automatically acquired Roman citizenship, which implied acquiring

37. In a forthcoming paper, Schwegler (Forthcoming) claims that Palenquero did not actually form in the village of San Basilio de Palenque. Rather, he suggests that this creole formed in a different maroon community and then, eventually, was taken to Palenque. In any case, this language would have formed in a context far away from the Spanish colonial rule. 
legal personality as well as all the privileges that Romans enjoyed over other nations within the Roman Empire. Manumission was common; restrictions on it were few, mainly limited to protect creditors from fraud (Marrone 2001: 119). ${ }^{38}$

Slavery was not based on race. Rather, anybody could become a slave, independently of his or her ethnic or national background. According to Roman law, human beings could be reduced to slavery if they belonged to any of these three categories: (1) prisoners of war; (2) offspring of enslaved mothers; (3) anybody who sold themselves into slavery (often to repay a debt). There was also the possibility for a father to sell his children as slaves; however, this practice was highly uncommon (Marrone 2001:111).

The lack of legal personality for slaves also implied that they could not own property. However, they were usually provided with a fund called peculium, which legally belonged to their master but which they were allowed to use within the restrictions set by their owner (Marrone 2001). The peculium was frequently designed as a percentage of the revenues provided by the slave to the master. It was cumulative and slaves could eventually use it to purchase their own freedom, at a price set by their masters. It worked as an incentive to work harder; it was meant to create additional profits for owners, since setting a slave free in exchange for the peculium did not represent any economic loss for the slaveholder, who could use the money to acquire a new slave.

Another consequence of slaves lacking legal personality was the inability of captives to take part in civil lawsuits. Their use as witnesses in civil cases was highly restricted and they could not give evidence against their owners. Emperor Constantine (320-23 A.D.) decreed that if slaves tried to accuse their owners, they would not be heard and would be crucified (Watson 1989:30). Finally, since slaves were property, they could not marry, either among slaves or with free people. They could have sexual partners but the institution of marriage, as well as the rights and duties that it implied, were denied to slaves. As a consequence, for example, they could not carry out an action against someone who committed adultery with their partner. Their offspring belonged to the owner. Slave couples, as well as their children, could be divided and sold to different masters. Overall, slave law in Rome mainly concerned private issues; it did not deal much with the

38. The fact that manumitted slaves would not only automatically become free people, but also Roman citizens, generated no little concern among the Roman population. Two laws were promulgated at different points in time to constrain such a phenomenon: the Lex Fufia Caninia (2 B.C.) and the Lex Aelia Sentia (4 B.C.). The Lex Fufia Caninia imposed an upper limit on the percentage of slaves that could be manumitted by last will; while the Lex Aelia Sentia provided a set of stricter constraints regulating manumissions, such as the impossibility of manumitting misbehaving slaves (Marrone 2001: 119). 
public sphere of society. For this reason, a slave owner was free to do whatever he wanted with his slaves; there were no government instructions on how to punish, educate, employ, etc. a slave (Watson 1989: Ch. 2).

The best-known and most influential legal text collecting Roman laws is the Corpus Juris Civilis (CJC). It was created from 529 to 534 under the administration of emperor Justinian. This text had a deep impact on the legal history of Europe. In particular, it shaped the legal systems that developed in the regions that had been more deeply colonized by the Romans (Hespanha 2003). In the following sections we will explore the extent to which the CJC and its slavery regulations were received by the European legal systems that subsequently would be transplanted and implemented in the Americas. This will help us achieve a better understanding of the legal systems that regulated living and working conditions of black captives in the different European colonies across the 'New World'.

\subsubsection{Spanish slave law}

Slavery had been established in Spain since the Roman colonization of the Iberian Peninsula. Spain, along with Portugal, was among the few European countries that possessed a long tradition of slavery regulation by the time the 'New World' was discovered. In the Spanish case, a good part of the Roman legal heritage had been codified in the thirteenth century under the direction of King Alfonso el Sabio in the Siete Partidas code, which had inherited - with few modifications the Roman legislation on slavery proceeding from the Justinian Corpus Juris Civilis. The Siete Partidas provided the legal bases for the further development of the Spanish legal system in the Americas, which gradually was adapted to the new colonial needs through the progressive promulgation of the Leyes de Indias 'Laws of the Indies' (Burns 2000). This represented a legal tradition that was absent from the majority of the other European colonial powers. As we will see, this fact was key in shaping the dynamics of the slave-master relation overseas and consequently, I claim, the nature of the languages that developed in the different colonies across the Americas.

The Spanish legal system was deeply rooted in the principles contained in the CJC. Along with slavery, the Spanish system inherited the concept of property and the different ways in which property could be acquired. One of such ways was the accessio. It consisted of the incorporation of one thing into another. The person who owned the main thing became the owner of the combined thing. Thus, for example, the owner of a certain field automatically became the owner of the plants and crops which would grow on it (Marrone 2001). During the Middle Ages, this ancient property concept was re-elaborated and applied to the validity 
of legal systems. As a consequence, a given legal system, adopted in a certain territory, would automatically become valid for the regions incorporated by such a territory. Therefore, after the discovery of the 'New World', the regions granted by the Papal bull Inter Caetera to Spain became part of Castile (see Section 5.2). As a result of accessio, the Castilian law automatically applied to those territories. This implied that in the Spanish colonies there was "law regulating slavery before there were slaves to be regulated" (Watson 1989:47).

Such a slave law, which in Spain was already centuries old when the New World' was discovered, was designed not according to socio-economic needs that would develop in the Spanish colonies but rather in line with the demands of society in 13th century Spain. Much of it, moreover, had derived in large measure from the rules of Roman law as they were set out in the CJC. In fact, according to the Siete Partidas the main reasons to reduce somebody to slavery were exactly those indicated by the CJC: (1) war prisoners; (2) children of an enslaved mother; (3) people who decided to sell themselves into slavery. One relevant difference, which developed in the Spanish code due to the influence of the Catholic Church, had to do with point (1): war prisoners could be enslaved only if they were non-Christian (Andrés-Gallego 2005). ${ }^{39}$

One key factor differentiated Spanish slavery from Roman slavery: slaves under Spanish rule were legal persons. Granting legal personality to slaves was the result of a radical departure of the Spanish system from the Roman legislation (Andrés-Gallego 2005). The presence of legal personality implied a variety of rights and duties ascribed to the Spanish captives, which were unknown to Roman slaves. Slaves, therefore, could take part in legal lawsuits both as plaintiffs and defendants. According to the Siete Partidas, a slave could not be punished too harshly and had the right to be clothed and fed. In case the master did not meet such requirements, the slave could take his owner to trial and ask the judge to be sold to a different master. In order to be able to adequately defend themselves during trials, a royal law of 1528 assigned a special lawyer to any slave in need of legal assistance, called protector de esclavos 'slave protector' (Andrés-Gallego 2005: 65). Slaves could get married and they could accumulate financial resources to purchase their manumission.

39. The systematic enslavement of Africans during the following centuries raised some moral concern since Spain and Portugal did not really wage wars in Africa to obtain their black slaves. These were almost without exception obtained via African slave traders, who had either captured them individually, or through larger raids and/or wars. For this reason many people questioned the legitimacy of such cases of enslavement. Navarrete (2005) provides an overview of the debates concerning this sad chapter of the transatlantic history. 
In the original Siete Partidas, as in the CJC, slaves could not own property, but they could receive the peculium if their master agreed to provide them with it. The peculium, therefore, in the Siete Partidas, was not compulsory; rather, it was just common practice. However, the Ley de Indias promulgated in 1541 made it required in Spanish America. This compulsory peculium had to be paid to slaves either in cash, or with material goods, or by providing them with time off and production means (e.g. a piece of land on which to grow their own crops) (Andrés-Gallego 2005:60). Moreover, an additional and more sophisticated legal instrument to achieve manumission was developed in the Spanish Indies. It was called coartación. It was a contract that consisted of a sort of 'manumission mortgage' where slaves could acquire their freedom by providing the master with periodic payments: the more they paid, the more they could enjoy their freedom, thus the more chances they had to accumulate capital to pay off their debt (Andrés-Gallego 2005:63).

Therefore, Spanish slavery regulation significantly evolved from the CJC to the Siete Partidas and, subsequently, to the Leyes de Indias. The reception of Roman slave law in ancient times provided Spain with several centuries to adapt and gradually modify such regulations to better meet the natural evolution of Spanish society and of its institutions. This was somewhat unique to Spain. It did not happen in the other European countries which would be subsequently involved in the colonization of the Americas. The concept of legal personality benefitted slaves not only on the legal and economic levels - with the possibility of taking part in legal lawsuits, the possibility of relying on the protector de esclavos, the capacity of accumulating capital to pay off their debt and become free people, etc. - but also on the familiar level their life changed radically from what was originally established in the CJC. The Catholic Church played a key role in this. Indeed, the Church insisted that slaves had souls. In caring for souls, the Church managed to take away some of the power that masters had over their captives. For example, to avoid the sin of fornication, the institution of marriage had to be conceded to slaves. This provided slaves with some additional element of personality. Moreover, slave marriages had to be preserved, thus a slave husband and wife could not be separated (Watson 1989). As a result, two married slaves belonging to two different masters could not be divided by the owners against their will. For example, in the case that an owner from say Lima (Peru) decided to move to a different location, say Quito (Ecuador), and his male slave was married to an enslaved woman residing in Lima, then the owner would have to either purchase his wife and take her to Quito, or sell his slave to a Limeño resident. Interracial marriages were common and even more common were interracial sexual relations. Owners often freed the children they had from their enslaved lovers. These Spanish customs led to a growing free mulatto sector in all Spanish colonies. 


\subsubsection{English slave law}

Watson (1989) indicates that slavery in the English colonies was remarkably different from the institution found in Spanish America. The reasons for this had to be sought in the fact that Roman law had not been received in England so that the institution of slavery did not exist in this country at the time of the American colonization. Watson states that in order to overcome this legislative gap "a law of slavery had to be made from scratch" (Watson 1989:63).

Apparently, the non-reception of Roman law also implied the lack of the notion of accessio in the English medieval legal system, as Blackstone (1765) indicated and Watson (1989:65) highlighted. As a result, a key difference between the territories colonized by the Spaniards and those conquered by the English emerged in the regulation of many aspects of social life. Watson states (1989:65):

The difference in Spanish and English law here is fundamental. The law of the Spanish colonies was the law of Castile as it was and as it would become. Law could only be made in the colonies by governors, viceroys, or others to the extent that power to do so had been expressly granted by the ruler of Castile. The lawmaking power remained in Spain. In the English colonies, the basic laws were those made by the colonists in the colonies.

Watson (1989: Ch. 4) explains that English colonies did not have a law of slavery when the first slaves were introduced in the territories overseas; rather, the legislation started being created step by step, mainly by judicial court precedent and by statute. In both cases, the decisions made to shape such systems were not imposed from England. On the other hand, they were the result of local processes, involving local judges and local colonial authorities.

Judges therefore had to create laws on slavery, in a context in which a previous code on such an institution was lacking; a common practice to accomplish such a task was to recur to Roman law and therefore to fragments of a system that was comparatively harsher on slaves than the system developed by the Spaniards over time and formalized in the Siete Partidas. As for the law created outside of judicial courts, the local legislatures passed a variety of statutes that oftentimes dictated even stricter regulations on captives and manumitted blacks.

Watson highlights that a visible difference between the English system, which emerged in the colonies, and the Roman one had to do with the fact that the former was much more regulated than the latter in its public sphere. In fact, Roman slave law was mainly a system of private law, which did not publicly regulate the relations between slaves and masters. In Rome, it was the master who decided how a slave should be punished, what he should wear, where he should live, how he should be educated or trained and so forth. The Roman state did not have a 
say on these issues. Conversely, in English America, all these aspects of slave life were regulated by law; oftentimes the slaveholder was not even allowed to treat his slave better than what was established by the local legislatures.

Watson even claims that while a slave in Spanish America could be considered to belong to his owner, in English America it appeared to belong to "every citizen - at least he was subordinate to every white" (Watson 1989:66). In fact, any white citizen had the right to stop a black outside of a plantation and question him about what he was doing. The local government established the type of clothes that slaves should wear; it would organize patrols of white people to catch runaway captives and would give the masters a certain frame of time to inflict a pre-established punishment on them. The local authorities also forbade formal education for blacks. Slaves could not buy and sell any sort of products since they could not own anything. For this reason, the master could not even decide to donate animals or other goods to them. They had to live with their master and were not allowed to live in another area, even if the owner agreed.

Watson illustrates some passages of the slave law implemented in South Carolina. In particular, he reports extracts from the first South Carolina statute on slavery called the "Act for the Better Ordering of Slaves" from 1690. This document states (Watson 1989:68-69):

And if any negro or Indian slave shall offer any violence, by striking or the like, to any white person, he shall for the first offense be severely whipped by the constable, by order of any justice of peace; and for the second offense, by like order, shall be severely whipped, his or her nose slit, and face burnt in some place; and for the third offense, to be left to two justices and three sufficient freeholders, to inflict death, or any other punishment, according to discretion; provided such striking or conflict be not by command of or in lawful defense of their owner's persons.

Watson highlights the fact that this Act, which in itself had borrowed much from the Statute of Barbados of 1688, served as a model for several other US states. He provides many other samples of regulations that highly restricted the freedom of blacks as well as the freedom of slaveholders, who had to inflict the punishment established by the law on their captives, and could not provide them with benefits that were not contemplated by the statute.

The author indicates that many US codes strictly forbade the masters to allow slaves to rent out their work for money, or to gain a peculium, or work a parcel of land for their own benefit. Slaves in the English colonies, as in ancient Rome, had no legal personality; they were classified as movable property. Because of this condition, slaves could not sue their masters or any other people. Moreover, in civil actions, they could not act as plaintiffs or defendants. Nevertheless, they could be defendants in criminal actions and there existed a specific legal system 
that regulated criminal law specifically for slaves. Watson (1989) indicated that 'Procedure for slaves' crimes was more summary, penalties were more severe when the offender was a slave, and there were crimes that in effect could only be committed by slaves" (1989:72).

As for manumission law, Watson (1989) points out that achieving the state of 'free black' was not as common and easy as in the Spanish colonies. He shows that in the original South Carolina statute there was no reference to manumission. The first clear reference to manumission is from the statute of 1712. In this document, section 1 indicated that slaves could be manumitted by their masters or by a governor of provincial council given a good reason. The statute of 1735 clarified that manumitted slaves had six months to leave the province. If they did not do so, they could be re-enslaved by local authorities. The reason behind this law had to do with what was probably a common practice: slaveholders tended to free captives who were not productive enough or of bad character, in order to not have to feed them and pay property taxes on them. To solve this issue, Section 7 of the act of 1800 indicated that manumission was contingent upon local government approval to make sure that the captive was able to earn a living and did not have bad habits. Progressively, the legislation became stricter on this issue. In 1820 the statute declared "that no slaves could be freed except by an act of the legislature" (1989:75).

Another act from 1740 also forbade teaching how to read and write to blacks. Similar regulations were also present in legal codes from North Carolina, Georgia, Alabama, and other states. Watson classifies as "striking" the interest of the government in regulating the public dimension of slaves' lives, while not much was usually said about private law (1989:72). For example, nothing is mentioned about slave marriages, which were not considered as being legally valid. Slaves could not get married in the majority of the British American territories; enslaved couples could be separated and sold to different buyers without any limitation; interracial relations were highly prohibited. As we can see, the lack of legal personality automatically implied the lack of a variety of related rights. This limited slaves' initiatives on both the private and public spheres of their lives. In particular, we can observe that the legal, financial and family-related freedoms of slaves were systematically more limited than their respective Spanish counterparts. This situation inevitably had a negative effect on the opportunities for English slaves to climb the social ladder and thus automatically reduced their chances of social integration. Such segregation probably favored the formation and preservation of contact varieties in the English colonies that diverged more radically from their lexifiers than the dialects that developed in the territories under Spanish control. 


\subsubsection{French slave law}

France, unlike England, had received the Roman CJC. However, the reception of Roman law was not as intense as in the Spanish case. In fact, scholars working on the legal history of France traditionally describe this region as a land in which two main private legal traditions coexisted until the advent of a progressive and systematic homogenization, started in 1454 by Charles VII and subsequently implemented by the central governments in the following centuries (Hespanha 2003). One legal tradition was based on customary law, rooted in local customs and generally not written. It was applied in the northern territories (pays de droit coutumier). Conversely, in the southern territories ${ }^{40}$ the law was written (pays de droit écrit) and had been influenced more significantly by the Roman CJC.

In certain regions, serfdom was in place up to 1798 . It consisted of services that rural peons had to perform freely for their landlord; this system, however, differed significantly from the Roman one. Moreover, it did not belong to the Paris legal system (Coutume de Paris), the one which was introduced to French America. Therefore, unlike Spain, medieval France did not have a collection of laws on slavery. For this reason, while slavery evolved in the Spanish system and gradually provided more rights to the slaves, in the French system such a process could not possibly take place.

At the time of the American colonization, the French did not have the accumulated centuries of slave legal tradition as the Spaniards did. Like the English, they had to create new rules, designed on an ad hoc basis to address differing local situations. To do that, they borrowed massively from the ancient CJC. This legal effort eventually resulted in the Code noir, originally passed by King Louis XIV in 1685, which differed significantly from the Spanish slavery regulations, developed through the centuries and crystallized in the Siete Partidas. This code also differed from the slavery law developed by the English. Watson (1989:85) points out two key differences: first, the French law was not created in the colonies where slaves and masters lived and the legislator might have designed a system to address their needs; rather, it was created in Paris, where the circumstances were completely different from those found in the colonies. Second, these regulations were put together by lawyers trained in Roman Law and the socioeconomic situation encountered in ancient Rome differed radically from what happened in colonial French America during the 17th century.

As we will see in the following paragraphs, given the direct borrowing from the CJC, French slaves did not have legal personality. Slaves were movable

40. These territories roughly corresponded to the areas occupied by the Visigoths and the Burgundians (Watson 1989: 83). 
property, as chattel. For this reason, they could not own any material goods. However, in line with Roman law, they could be provided a peculium by their master, who could take it away from them at any time.

Overall, French regulations on manumission appeared to be more flexible than English rules. Watson (1989: 86) takes Article 55 of the edict of March 1685 for the French American islands to exemplify the state of manumission in the majority of the colonies where the Code noir was in place: "Owners who are twenty years old can free their slaves by any act inter vivos or mortis causa without being bound to give a reason for the manumission". Nevertheless, manumission over time became more difficult. In fact, after a royal ordinance of 24 October 1713, it was not enough for a master to agree to his slave's manumission. Rather, an application for manumission had to be submitted to the local authorities and the governor or an administrative commissary had to sign it to give the master the permission to free his slave (Andrés-Gallego 2005:248; Watson 1989: 90).

Similar to the English slave law, the Code noir paid more attention than Roman law to the public sphere of slavery. For example, for certain slaves' behaviors against their masters there were fixed punishments decided by the state, which could not be modified according to the owner's will. For instance, in the case that a slave struck "his master, his mistress, her husband, or their children on the face so as to bruise or cause bleeding" (Watson 1989:85) the fixed punishment by law had to be death; it did not matter if the master forgave his slave. Such an act of revolt was not perceived as a private issue between an owner and his captive; rather, it was considered as a public security issue, and therefore, it would have to be addressed by public regulations. ${ }^{41}$

The punishments inflicted on slaves were harsher in the French system than in the Spanish one. Slaves could not be tortured, but if found guilty of a crime, the punishment could involve amputations, iron branding and the death penalty. Since slaves had no legal personality, they could not take their masters to court if their rights were not respected.

Slavery was based on race, and the law strongly discouraged race mixing. A free person could not marry a slave; moreover, if masters had children by their slaves, such slaves and their offspring would be confiscated by the government authorities; they would become property of the closest hospital, and would never

41. Schwegler (p.c.) points out that also in the Spanish system certain issues were treated as cases of public offense, and consequently punished according to precise state regulations. This is certainly true; for example, there were pre-established punishments that had to be inflicted to the slaves that tried to escape. Nevertheless, it is a well-documented fact that the domain or crimes corresponding to the public sphere was much more extended across the English and French colonies than the Spanish ones (cf. Watson 1989). 
have a chance of becoming free people. In addition, masters would be forced to pay a high fine (Watson 1989:88). Due to the influence of Christianity, the Code noir acknowledged slaves' humanity. It considered slave marriage as valid and forbade the separation of family members to sell them as individual tokens. Marriage among slaves was, therefore, recognized by the authorities; however, slaves could not get married without their owners' permission.

As we can see, when we compare French regulations with the Spanish ones, we can immediately see how in the French colonies blacks' freedom and their chances of being accepted into free society were considerably more limited.

\subsubsection{Dutch slave law}

The United Provinces of the Netherlands received Roman law, but not uniformly. Some regions like Friesland and Holland were more influenced, while other provinces, like Groningen, Gelderland, Overijssel and Drente were never significantly affected by it. Even though the legislations regulating these provinces differed, an aspect that unified all of them was the lack of the institution of slavery. Moreover, the Dutch colonies in the Americas (Dutch Antilles and Suriname) were not technically controlled by the Dutch government; rather, they belonged to a private trading company (with a local governor and council), the Dutch West India Company.

Since neither the United Provinces nor the Dutch West India Company had a legal code regulating slavery, at first, when slaves were introduced into the Dutch territories, there was no slave law capable of regulating black captives' living and working conditions (Watson 1989: 103). In order to fill such a legal gap, the Dutch had to rapidly adopt some regulation, as the English and the French did. The Dutch also borrowed material from the CJC; however, the emanation of such regulations did not proceed from the local state legislation nor from judges, as in the British colonies overseas; nor did it proceed from their homeland back in Europe, as in the French and Spanish cases; rather, they were directly dictated by the Dutch West India Company.

Watson (1989) points out that the Dutch borrowed the bulk of slave law from the Romans and implemented systematic changes through the placaaten 'ordinances' only to address issues of public administration. He states (1989:110):

The problem is that the rules of the Roman law, as they were set out in the Corpus Juris Civilis and as understood by later scholars, were so taken for granted that they were not restated. And little of this law was changed. The placaaten basically added only local police law. 
For this reason, as in ancient Rome, slaves had no legal personality; thus they could not appear in court nor sue their masters, nor get married, nor own property. As in Rome, they could be provided a peculium, which the master could take away at any moment.

Watson (1989:106) reminds us that the placaaten were not uniform; rather they changed from colony to colony. He provides several examples from Curaçao and Suriname and decides to group these ordinances into three main categories. In the first group he places the "placaaten which particularly bring out the public law dimension" (1989: 106). This would include ordinances instructing masters to provide a certain number of slaves to perform a job of public interest (e.g. construction of streets, bridges, etc.), restrictions on slaves' free time activities (dancing, singing, going out at night), limitations on fishing, regulations for fugitive slaves (setting up funds to catch runaways, penalties for the escaped captives, etc.), regulations of the minimal proportion of whites to blacks on plantations, etc.

The second group of placaaten presented by Watson concerns the restrictions on "trading by or with slaves". Several of these ordinances were promulgated with the goal of reducing the sale of stolen goods (1989:106). Slaves were often prohibited from selling anything other than vegetables, fruits and other crops. Limitations were also imposed on whites who wanted to rent their houses or other properties to blacks since, apparently, it could happen quite often that slaves rented houses without having enough resources to pay for them. Other common placaaten forbade whites from purchasing gold, silver, alcohol, and other products from slaves, unless the captives could provide a letter from the owner or sheriff's deputy indicating that they had permission to sell such goods.

The third group of placaaten analyzed are those that "provided regulations for slaves and free blacks together" (1989: 107). Watson mentions ordinances prohibiting blacks to go out after a certain time without written permission from their masters; rules forbidding assemblies of blacks and mulattoes (e.g. a burial could not be attended by more than 6 people); regulations stating that blacks could not carry weapons of any sort, not even sticks; rules indicating that free blacks had to register for taxation, could not live with white women, nor buy alcohol, etc. Moreover, Watson points out that a master willing to manumit a captive had to obtain permission from the Edele Hove van Politie, the local Police Department. This bureaucratic step was introduced to make sure that the former slaves would be able to earn a living by themselves, without having to recur to theft to survive after manumission.

In summary, the direct legal borrowing from the CJC and the consequent lack of legal personality for slaves had a direct effect on limiting blacks' integration into the Dutch colonial society. 


\subsubsection{Portuguese slave law}

In the case of Portugal, the situation was again different. The Portuguese had received the Visigoth Code, which inherited the institution of slavery from the Romans. However, with exception of some Moorish captives, not many slaves were present in the territory after the Reconquista (Watson 1989:91).

Andrés Gallego (2005:246-247) highlights that the Portuguese legislation was the closest to the Spanish one (see also Tannenbaum 1946). He indicates that this was partially due to the fact that the law that was promulgated for the establishment and organization of the Portuguese colonies in the Americas (Ordenações filipinas) had been promulgated by Philip II, a Spanish king, who in the sixteenth century ruled both Portugal and Spain.

In line with the Spanish colonies, the Portuguese territories overseas received the homeland law via accessio. In this specific case, the law consisted of the Ordenações filipinas. This code, as well as the Siete Partidas, was rooted in the Roman Corpus Juris Civilis. The Ordenações filipinas indicated that "the owner could only punish a slave, as a father a son, or as master a servant" (Watson 1989: 100). However, this supposedly 'kind' treatment imposed on slaveholders by the code in some parts of the legislation was, at the same time, explicitly contradicted in others. In fact, "owners were permitted to mutilate slaves until 1824. A regulation of 1830 prohibited administering more than fifty lashes of the whip at any one time. (As a result, punishment might be spread over a long period)" (Watson 1989: 100).

In theory, slaves could not be treated cruelly; however, they did not have legal personality and therefore they could not complain in front of a judge in case of mistreatment. The only case in which they could act in a legal court had to do with issues related to religion, such as marriage. In fact, while in Roman Law slaves could not marry, due to the influence of Christianity on the Portuguese legislation, marriage between slaves was considered valid in Brazil and slave family members could not be separated, so that husband, wife and children could not be sold individually.

The legislation concerning slaves' ability to file lawsuits was a bit opaque. In fact, a slave could not take his master to court; nevertheless, if for some reason it was made clear to a judge that the master was vicious, the slave could request to be sold to a different owner (Watson 1989: 100).

Manumission was not as strictly regulated as in the French and English colonies; it only required the will of the master to free his slaves. As in Roman Law, some restrictions could apply to prevent fraud in case the masters had debts. The amount of money needed by a slave to buy his/her own freedom had to be established in line with a fair market price. Watson (1989:99-100) and Andrés-Gallego 
(2005:247) also point out the peculiar situation in which a slave would be manumitted by the royal house if he found a diamond of twenty or more karats, or if he denounced his master to the justice in case of illegal traffic (especially concerning products such as diamonds, gold, and precious wood).

Similar to the Spanish system, the peculium was contemplated by the Portuguese legislation; nevertheless, it was implemented in a different way, which highly limited the slaves' chances of saving money to achieve manumission. In fact, we saw that since 1541 some sort of compulsory peculium had to be provided to slaves in the Spanish Indies; on the other hand, in the Portuguese colonies it was not obligatory, so that only some slave owners would agree to concede it to their captives.

When we compare the Portuguese scenario with the Spanish one, certain similarities emerge. The early reception of the CJC by the Portuguese system, the presence of slave marriage, the possibility of obtaining the peculium and of being manumitted, as well as the pressure exercised by the Catholic Church had an effect on the lives of slaves, who were treated - to a certain extent - as human beings. These common patterns may have had a key influence on shaping the nature of the Afro-Portuguese varieties spoken in Brazil. Indeed, a detailed sociohistorical and legal investigation on the nature of Brazilian slavery may be able to cast new light on the debates concening the (non)creolization of Portuguese in a Latin American country, which, in line with Jamaica and Haiti, experienced massive introduction of enslaved labor force during the colonial period (cf. Guy 1981, 2004; Holm 1992, 2004; Naro \& Sherre 2000, 2007; Lipski 2006; Lucchesi, Baxter \& Riberio 2009). Nevertheless, the lack of legal personality for Portuguese slaves set a crucial difference between the legal status of Portuguese and Spanish captives; as a result, Brazilian slaves faced harsher social and economic barriers than the captives living in the territories under Spanish control.

\subsection{How did legal personality affect Spanish slaves' living conditions?}

So far this chapter has focused exclusively on the documentation concerning the formal aspect of slavery, as it was stated in the legal rules, "law in books", rather than the practical application of such rules to a specific social context, "law in action" (Pound 1910). In the present section, I will try to bridge the gap for the Spanish colonies overseas. This attempt, however, will always be - at best - an approximation of the reality, since it is materially impossible to provide a perfect picture of the past. As historian Crespo (1995:7) pointed out in his book Esclavos negros en Bolivia (Black slaves in Bolivia), 'La historia es siempre una aproximación' (History is always an approximation). I believe that this statement is 
particularly true when one is exploring a delicate topic as the Atlantic slave trade and is faced with only partial and scattered pieces of information (see Sessarego 2013d:363-364). This section attempts to put together some of these pieces to show that Spanish slave law, and in particular, the singularity of the legal personality of Spanish slaves, may have set apart these captives from the rest of the enslaved Africans living in other European colonies. This attempt, however, does not pretend to provide the answer to all the questions that gravitate around the Spanish creole debate; rather, what the Legal Hypothesis of Creole Genesis means to do is to highlight that a concomitance of factors conspired against the formation of Spanish creoles in the Americas, and that the Spanish legal regulation of slavery played a major role in this scenario.

This section consists of four parts. In the first one, I will provide a list of comments from a variety of colonial diplomats, clerics, and travelers who - at their time - compared Spanish slavery and its colonial regulations to the conditions to which slaves were subjects in other European colonies. Such a list of statements may provide a general and impressionistic account of how the Spanish 'law in books' might actually have been reflected in the social reality, or at the very least, of how such a reality might have been perceived by these observers in colonial times. The second part will try to show how the slaves' rights deriving from the presence of legal personality (in particular: property, family, the right not to be abused, and access to juridical means) are actually reflected in the available historical evidence we have for colonial Spanish America. These two different sources of information will provide us with a more precise picture of how "law in books" translated into "law in action". This will not provide a perfect reconstruction of colonial reality, but should, at least, help us get a closer look into it. The third section takes us back to Peru, to see how the general patterns illustrated in the preceding two parts apply to this specific Andean country. The forth section zooms into three particular colonial contexts, which have caused much debate in the field of creole studies: Cuba, Chocó (Colombia), South Carolina and Barbados. Such regions, where "law in books" may have deviated quite significantly from "law in practice," can be used as a powerful testing ground for the Legal Hypothesis of Creole Genesis; thus they will help us understand to what extent this hypothesis may make valid predictions.

\subsubsection{Historical remarks on Spanish slavery in the Americas}

It is not an easy task to understand to what extent the "law in books" has an effect on the "law in action" and therefore on the social reality at any point in time; however, if we look at the overall literature on Latin American history, we can 
find numerous remarks made by observers of the time who highlight how Spanish slave law was supposedly less harsh than slave regulations in other European colonies. Andrés-Gallego (2005: Ch. 6) provides a variety of examples that suggest that Spanish slave rules were less harsh than those of other European powers and that this clearly benefitted Spanish slaves' living conditions. He (2005:242) quotes a statement by the scientist Don Felix de Azara, who in the 18th century indicated that Paraguayan slaves were not treated as harshly as in other European colonies:

No se conocen esas leyes y esos castigos atroces que se quieren disculpar como necesarios para mantener a los esclavos dentro de los límites de sus deberes.

(Those laws and those cruel punishments that some people want to justify as needed to keep the slaves under control are unknown in this region).

Another case mentioned is the one by Alexander de Humboldt, who commented on the slaves of Mexico during his trip across the Americas (1799-1805) with the following words (2005: 242):

Se hallan como en todas las posesiones españolas, algo más protegidos por las leyes que los negros que habitan las colonias de las demás naciones europeas. Estas leyes se interpretan siempre a favor de la libertad, pues el gobierno desea que se aumente el número de negros libres.

(As in all Spanish colonies slaves are more protected by the law than in other European territories. These laws are always interpreted in favor of freedom, the government wants the number of free blacks to increase).

Andrés-Gallego (2005:242) also reports a remark made by Jeronimo José Salguero, consultant of the Audiencia de Buenos Aires in 1807. Mr. Salguero commented on a case of poor slave treatment that took place under his jurisdiction; he reflects on the evolution of slave law in the Latin American territories and compares it to the Corpus Juris Civilis:

Tanto más acreedor es un esclavo entre nosotros a un tratamiento suave y piadoso, cuanta es la diferencia de servidumbre, y sus motivos, entre los que conoce nuestro derecho y la que usaron los romanos.

(A slave is entitled to receive a softer and more sympathetic treatment among us than among the Romans; this is a reflection of the difference between our law on serfdom, and its reasons, and the Roman one).

Similar remarks on the less harsh treatment applied to Spanish slaves in Venezuela also come from an anonymous observer at the beginning of the 19th century (2005:243): 
El negro esclavo en Venezuela no es un ente aislado en medio del género humano, sin recursos, sin protección, sin bienes, sin esperanzas: no es en nuestra consideración un ser condenado perpetuamente a la fatiga y a las privaciones. $\mathrm{Si}$ en otros países los esclavos pueden existir en tan duras situaciones, en Venezuela las leyes, los magistrados y los intereses personales y comunes de los amos, más sabiamente calculados, les proporcionan para su conservación descanso en la fatiga, vínculos en la sociedad y contento en su condición.

(The black slave in Venezuela is not an isolated individual, without resources, without protection, without goods, without hope: from our point of view, he is not a being perpetually condemned to hardship. If in some countries slaves are subject to such harsh conditions, in Venezuela the laws, the judges, and the smartly calculated individual and community interests provide slaves with rest from hardship and better chances of becoming part of society so that they are happy in their condition).

One century later, in 1911, still in Venezuela, Núñez Ponte, in his work Estudio histórico acerca de la esclavitud y de su abolición en Venezuela (Historical study on slavery and abolition in Venezuela), comments on the laws that would punish slave owners who did not respect slaves' rights and on the possibility for captives to rely on the legal assistance of a state lawyer, who would provide them with his services for free (procurador de pobres, also known as procurador de negros) (2005:243):

Ni tampoco usaron los españoles con sus esclavos de demasiada sevicia; [...] Había leyes altamente filantrópicas que [...] en algo suavizaban el rigoroso destino de los negros, y señalaban penas a los señores que en demasía les torturaban; y un procurador de pobres ejercía gratuitamente la función de defenderles cuando se hubiese menester.

(The Spaniards did not abuse their slaves too much; [...] there were highly philanthropic laws that softened blacks' living conditions, and indicated punishments for the masters who mistreated them; and a procurador the pobres defended them freely whenever it was needed).

Andrés-Gallego (2005: 244) also quotes historian Fernando Ortiz (1916), who in the same century highlights how British and French captives underwent much harsher treatments than Spanish slaves:

Muchos suplicios descriptos por viajeros de las colonias francesas e inglesas [...] demuestran o que su celo antiesclavista o narrativo les hizo presentar como frecuentes, hecho del todo desusados, o que la esclavitud en aquellas pequeñas colonias antillanas era mucho más cruel que entre los españoles, circunstancia esta muy verosímil y creíble dada la gran abundancia de documentos justificativos de la refinada crueldad de los plantadores de las otras colonias de las indias. 
(Much of the tortures described by travelers who visited the French and English colonies $[\ldots]$ show that either they were common there, and not here, or that slavery in those little Antillean colonies was much more cruel than among the Spaniards; this is quite realistic and believable given the abundance of documents showing the sophisticated cruelty of those Caribbean planters).

All these quotes suggesting that Spanish laws were less brutal than other European regulations and that such a legal difference was clearly reflected on the real living conditions of colonial slaves are not isolated remarks systematically selected by historian Andrés-Gallego. The literature on the legal history of Latin America is replete with such comments (see for example Mac-Lean y Estenos 1948; Genovese 1967; Finley 1980; Berlin 1997; Bryant 2005; etc.).

Lucera Salmoral is arguably one of the most knowledgeable historians with an expertise in colonial Latin America and black slavery (see for example Lucena Salmoral 1994, 1999, 2000a, b, 2002). To exemplify how the differences in the legal and social structure of the Spanish territories overseas would be reflected in the actual reality of such a colonial scenario, Lucena Salmoral (1994:63) quotes a letter dated March 31, 1794, from the Consejo de Indias describing the fundamental differences between Spanish, English and French colonies in the Americas. The Consejo's director of several departments (La Habana, Santo Domingo, Louisiana, Caracas) indicated that the French and the English imported on average 50,000 bozales yearly (25,000 each). This was done to maintain a constant number of workers, many of whom died from the harsh living conditions. On the other hand, Spanish colonies had relatively high birth rates and a longer life expectancy; this reduced the need for new bozales. The reduction in the number of slaves in Hispanic America was due to the relatively high manumission rate. Moreover, interethnic marriages were allowed, giving birth to mixed-race individuals (castas), some of whom were free:

Entre los españoles se disminuye el número de esclavos por la facilidad con que se libertan, pero no porque parecen entre los rigores de un trato inhumano, pues en el fondo las varias castas, llamadas gentes de color, que deben su origen a la esclavitud.

(Amongst the Spaniards the number of slaves tends to decrease because it was easier to achieve manumission, but not because slaves would die due to inhumane working conditions, this gave birth to a variety of mixed races, called colored people, who originated from slavery).

As we can see, a variety of colonial observers, from different Spanish territories across the Americas, agreed that the Spanish slave law was less brutal than the one designed by other European colonial powers in the Americas and that such legal differences had a clear impact on the living conditions of slaves: less harsh 
treatments (because harsh treatments were punishable by law), more opportunities to integrate in society, the possibility of recurring to legal means (protector de pobres/esclavos) when their rights were not respected, higher rates of manumission, the possibility of interracial marriages (which also implies the recognition of marriage for slaves), etc.

These quotes may provide a general impression of how dissimilar legal systems might have influenced the lives of slaves in different European territories. The following section will try to corroborate these statements with actual instances of "law in practice" to show to what extent the singularity of the legal personality ascribed to Spanish slaves may have affected their living conditions in relation to three main spheres of their life: owing property, right to a family, and right to not be punished too harshly.

\subsubsection{The legal practice of Spanish slavery}

A crucial aspect of African slavery in Spanish America was the importance given by the Crown to the fact that slaves were human beings with souls (Watson 1989). As Bowser (1974) correctly pointed out, masters had to baptize their slaves and provide them with Christian education. By law, slaves could not work on Sundays and during religious festivities. Many religious groups, in particular the Company of Jesus (the biggest Latin American slaveholder), put a lot of emphasis on the Christianizing mission of the Spanish Empire. Language teaching was often seen as a key means to achieve the correct reception of the Christian faith. In fact, it was compulsory for all slaveholders in Spanish America to provide their slaves with Christian education and to teach them the Spanish language. If a master was caught violating such a requirement, he would have been forced to pay high fees (Watson 1989).

To exemplify how slaves had to be treated and educated in the Americas according to the Spanish Crown, it may be insightful to look at the following three extracts, taken form a King's ordinance of 1545 (cf. Konetzke 1953:237-238). Extract one shows clearly that the masters had to treat slaves in a human way, and even when punishing them, the castigation could not be unreasonably harsh.

Primeramente se $[\ldots]$ ordena que todos los señores de negros tengan cuidado de hacer buen tratamiento a sus esclavos, teniendo consideración que son próximos y cristianos, dándoles de comer y vestir conforme a razón, y no castigalles con crueldades, ni ponelles las manos, sin evidente razón, y que no puedan cortalles miembro ni lisiallos, pues por ley divina y humana, es prohibido, a pena que pierdan el tal esclavo para S.M. y veinte pesos para el denunciador. 
(First of all, we order [...] that all the slaveholders take good care of their black slaves because they are related to us as Christians; masters should feed them and clothe them, they should not punish them cruelly, not even hurt them without a good reason; they are not allowed to amputate any parts of their bodies not causing them any permanent damage, since it is forbidden by both the divine and the human laws. If they do it, the slave will be taken away from them, and they will have to pay a fee of twenty pesos, which will be given to the denouncer).

The second paragraph stresses the importance of providing slaves with Christian education during the days off and to make hacienda workers pray on a regular basis:

Item que todos los señores de haciendas [...] tengan en ella un hombre blanco como mayordomo o mandador, el cual tenga cuidado que en dicha hacienda esté una casa o bohío como iglesia con su altar, con la señal de la cruz e imagines, y allí cada día por la mañana, antes que vayan los tales negros e indios a trabajar al campo, vengan a hacer oración [...], y todos los domingos y fiestas, después de comer, habiendo aquella mañana tenido misa con el santísimo sacramento de la eucaristías, se junten en la dicha iglesia o casa de oración y allí les enseñen la doctrina Cristiana, de manera que estén instruidos en la fe; [...] a los tales amos y señores de los dichos negros e indios, demás de que se les pone de treinta pesos, por cada vez que dicho señor Gobernador fuere a visitar la gobernación y no hallare que se cumple esta orden y que está en su costumbre cotidiana.

(In every plantation [...] there must be a white supervisor, who has to make sure that in the plantation there is a house or a hut functioning as a church with an altar, a cross and holy images, and in that place every morning, before going to work, blacks and natives must pray [...], and every Sunday and celebration day, after lunch and after having attented the mass and having received the holy sacraments, workers have to get together and pray, they have to receive Christian education, so that they will be able to understand the faith; [...] if the governor while visiting the plantation should realize that this regulation is not systematically respected, the owners will have to pay a fee of thirty pesos).

The third extract is of great importance from a linguistic standpoint. Spanish language teaching was in fact mandatory; the masters had to teach Spanish to their slaves within six months from the time of purchase. This was considered fundamental by the Crown to allow for a better understanding of the Christian faith:

Item [...] se les manda a cualquier señor de negro o negros, que como compren un negro esclavo, dentro de seis meses tengan cuidado como entrare en su poder, de hacelles aprender nuestra lengua vulgar y dalles a entender el sacramento del agua del santo bautismo y hacerlos bautizar y cristianar; pues todos los negros de su inclinación son amigos de los cristianos y fáciles de convertir a ello y lo tienen por presunción y valor ser cristianos como nosotros [...] y si se le probare haber 
tenido descuido en esto y que se le ha pasado el dicho término y no ha procurado hacer lo que ansi arriba se declara, incurra en pena del valor de la cuarta parte del negro la primera vez, y por el Gobernador que fuere, le sea puesto otro término, cual le pareciere, para que lo haga; y si la segunda vez fuera remiso, pierda la mitad del valor del negro; y por la tercera todo el negro [...] y si alguno que ansi comprare o hubiere en su poder el tal negro bozal y lo quisiere vender o trocar o enajenar antes de cumplidos los dichos seis meses, y no lo hubiere fecho cristianar, no lo pueda enajenar, sino fuere con el aditamento susodicho, y que el tal cargo tome sobre sí el que ansi después lo hubiere, so la dicha pena al uno y otro, vendedor y comprador.

(It is mandatory for all slave owners to teach our common language to the slave within six months from the time of purchase; they also have to explain the meaning of the sacrament of baptism, they have to baptize them and teach them into the Christian Faith; indeed all the blacks are friends with the Christians, they are easy to convert and happy to become Christian [...] and if there were evidence that after such a period of time the slave owner did not meet the aforementioned requirements, then he would lose one fourth of the slave value the first time; for the second time, he would lose half of the value; and for the third time, the whole value [...] and nobody in possession of a black bozal can sell him, or exchange him, or cede him after those six months without having taught him into the Christian faith; if this were to happen both the giver and the receiver would be guilty and would have to pay the consequences for their actions).

From the early times of the Spanish colonization of the Americas, the Spanish Crown, pressured by the Catholic Church, stressed the importance of not punishing slaves too harshly and of Christianizing them, thus teaching them the Spanish language. The Spanish Crown was highly committed to achieving such goals and promulgated a great number of laws to address such issues in all the Spanish colonies overseas (see Konetzke 1953; Lucena Salmoral 2005). However, the question here is to understand to what extent such rules were actually enforced. Were these regulations just depicting "in books" a highly idealized slave status that was completely disconnected from "law in practice"? Or did such regulations really affect slaves' lives?

As we saw, a variety of observers from that time appeared to indicate that Spanish regulations significantly influenced slaves' living conditions and made them overall much better than the conditions in which black captives had to live in other European colonies. The historical data that emerge from colonial legal court reports also appear to support such a view. Nevertheless, arguing that all Spanish masters were always kind to their slaves would definitely provide a misleading picture of colonial black captivity. In fact, there is clear evidence that in many circumstances slaves were abused and treated cruelly by their Spanish owners (see Andrés-Gallego 2005:176-185). However, it has to be said that both the 
Church and the Crown managed to take away some of the power that masters had over their slaves. As Bryant (2004:4) states "laws and royal edicts emanating from the metropolis [Madrid] encroached upon the master's domain while the clergy's determination to have exclusive authority in the administration of sacraments like marriage further eroded masters' authority over human chattel".

Historians working on Spanish colonial slavery were able to provide a variety of data clearly showing how captives' legal personality played a key role in providing blacks with better standards of living as well as more chances of climbing the social ladder (Watson 1989). Studies in the field are replete with documentation showing how slaves relied on the legal means available to them to fight for their own rights (Bryant 2004, 2005). In particular, they fought for the very basic rights stipulated in the Leyes de Indias such as: not suffering from unjustified punishment, the right to have a family, and the right to own property - especially in connection with the possibility of purchasing their own freedom. Indeed, many are the trials involving slaves suing their own masters for poor treatments. One of such trials is the case of Claudio and Bonifacio, two slaves who in 1798 appeared before the high court of Quito (Ecuador) to complain about the harsh treatments they received by their overseer in a mining camp near Barbacoa (current Colombia). After analyzing the case and realizing that the overseer was guilty of illtreatment (sevicia), the judges transferred the case to the officials of Barbacoa to further explore how to provide Claudio and Bonifacio with protection for them and for their families (Bryant 2004:33-34). Another case of mistreatment is the one of Ignacio, who belonged to Dr. Marcos Infante, and denounced his master in 1764 to the Governor of Córdoba (Argentina) because he punished him too harshly and without a proper reason. After an investigation, Ignacio succeeded in having Marcos Infante put in jail. In order to be set free, the master had to agree to sell Ignacio to a different owner (Andrés-Gallego 2005: 194).

There are also many records of colonial court cases concerning the right of slaves to have a family. Andrés-Gallego (2005:214-215) mentions the case of a peculiar trial in San Miguel, Tucumán (Argentina) in 1764, where the local tribunal, in order to preserve a slave marriage, forced a master to pay a fifteen pesos fine and to sell his lover, an enslaved woman, who was already married to another slave. Another trial related to marriage was started by slave Pedro Pablo Moreno in 1770 in Lima (Peru). Pedro Pablo denounced his owner because he did not allow him to spend Saturdays and Sundays with his wife, who belonged to a different master. Eventually, after it was discovered that the master had also punished the slave for no real reason, the tribunal decided to take the captive away from such a violent owner and assigned him to a notary working for the same tribunal (Andrés-Gallego 2005: 194). 
Also common were the trials related to property and manumission. One is reported by Andrés-Gallego (2005:197) and concerns the appeal to the court of San Miguel, Tucumán (Argentina) made by slave Juana María Artaza, who sued her master, father of her kid, for not giving freedom to her and their offspring. In fact, Juana María accused the owner of promising her manumission if she agreed to have an affair with him. The court provided her with a defensor de negros who was able to find two reliable witnesses and won the case. The court decided that Juana María could achieve manumission if she managed to put together the relatively modest sum of two hundred pesos. Moreover, in order to protect her for her master, she was momentarily put under the control of a new owner, Fray Pedro de Artasar. Another case related to slaves' accumulation of property is the one of Joaquín, who in 1768 in Guadalajara (Mexico) was accused by his former owner, Don Carrete, of having accumulated one hundred sixteen pesos by means of stealing, so that Carrete felt justified to take such a sum away from Joaquín. On the other hand, Joaquín claimed that "los había ido juntando de premios que le daban los que hacían empleos" (he put the pesos together by receiving over time the right compensations for his work). After a trial that lasted exactly one year, the court decided that Joaquín was right and that Carrete had to refund the money he took from him (Andrés-Gallego 2005: 199-200).

As we indicated in Chapter 5, Andrés-Gallego (2005:208) suggests that urban slaves could recur quite easily to the protector de negros to sue their masters. He even suggests that in some cases they would do it to gain time off from work (2005:210). This author also highlights that of all the legal cases he examined during the decade 1760-1770, the vast majority was favorable to the slaves' requests (2005:218-219). Obviously, it would be naïve to think that all black captives in Spanish America could easily recur to the protector de esclavos. In fact, it is true that not all slaves could enjoy the same degree of legal protection. Those who lived closer to the capitals or to big cities had more access to legal means to sue their masters than those who lived further away (Andrés-Gallego 2005:202, 221-223). Nevertheless, even assuming that some owners would manage to violate slaves' rights and prevent their captives from taking them to court, the number of blacks who succeeded in obtaining justice was amazingly high, especially if compared to the rest of the other European colonies, where slaves - deprived from legal personality - did not even have a chance to do so. Andrés-Gallego (2005:217) rephrases Meiklejohn's (1981:192) words to illustrate this concept:

Aun suponiendo que - como es verosímil - hubiera amos que maltrataran a sus esclavos y consiguieran impedirles que los denunciasen, y procuradores que no se quisieran malquistar con aquellos, el número de esclavos a quienes se hizo 
justicia y el número de procuradores que cumplieron con su deber defendiéndolos, concretamente en Santa Fe de Bogotá durante el siglo XVIII, es simplemente impressive.

(Even if we suppose that - as it was probably the case - there were slave owners who mistreated their captives and managed to prevent them from filing a lawsuit, and lawyers who did not want to help them, the number of slaves who received justice and the number of lawyers who did their job in Santa Fe de Bogotá during the 18th century is just impressive).

It is true that slaves working in remote areas, far away from cities, would have had far fewer chances of enforcing their legal rights than urban captives. However, it should also be pointed out that a great percentage of the slaves used in rural areas belonged to the Company of Jesus, which in some colonies owned more than one fourth of the total number of slaves (see Andrés-Gallego 2005: 188). The Jesuits, as is well-known, implemented a working system that strove to maximize slaves' productivity and loyalty while minimizing the risks of revolts. To do so, they respected captives' rights and adopted a managerial strategy with blacks that has been repeatedly identified as less brutal and more humane than the one of other masters in the Americas (see Macera 1966; Andrés-Gallego 2005: Ch. 5). They facilitated language acquisition through systematic Christian indoctrination, supported slave marriage to incentivize and preserve the creation of slave families, provided each family with a house and a piece of land to work for its own benefit, thus favoring the accumulation of property and a certain degree of social flexibility. These tactics had the final goal of developing stronger bonds between the slaves and the haciendas (Bouisson 1997; Bryant 2005; Sessarego 2014b).

Even though we have seen how a variety of observers' remarks and court reports show that the Spanish slave "law in books" had a clear effect on the "law in practice", we must also accept that sometimes such regulations might not have been systematically applied, so that - in some cases - a fair peculium might not have been paid to a captive, some slaves might have been mistreated without a reason, a married couple might have been separated against the law, etc. Nevertheless, besides those infractions, which may happen in all societies and are quite difficult to quantify at this point, it must be stressed that the aforementioned actions were considered illegal in Spanish America (and therefore punishable by law), while in the remaining European territories they were not seen as infractions at all; rather, they were perfectly in line with the legislation. This simple fact must have played a key role in the way black-white social relations developed in the Americas. Believing that in practice no real difference existed among all these European colonies with such heterogeneous slave laws would be a big historical mistake.

The way slave law was set in Spanish America provided black captives with more chances of improving their social conditions than any other legal system 
did. This, inevitably, had an effect on the slaves' integration into colonial society. ${ }^{42}$ Unlike other European slaves, Spanish captives were legal persons. Thus, they had a precise set of rights and duties. Latin American Spanish slaves could own property, as they could accumulate financial recourses. They were entitled to a peculium and could enter contracts such as coartación to better achieve manumission. They had the right to a family. They could not be mistreated without a reason and could take other people to trial (even their masters) if their rights were not respected.

Conversely, in the remaining European colonies, black slaves did not have legal personality; thus, all the aforementioned rights were either absent or highly restricted. Moreover, we observed that in some legal systems the public sphere of slavery was much more emphasized and regulated than in the Spanish and Roman traditions, so that limitations were also imposed on slave owners, who, in some cases, were forbidden from treating their slaves better than what the law had established. The Spanish colonial administration, on the other hand, was not generally interested in the public aspect of slavery. Overall, the Spanish Crown was not much concerned with segregating the blacks or forbidding black/white racial mixing. The lower the level of public regulations on this aspect of interracial relations, the more open and (consequently) the more socially tolerable would be sexual relationships, not necessarily excluding marriage, between blacks and whites. And the more tolerable such mixed families became, the more socially acceptable the offspring of mixed race would be. All these elements (in one way or another deriving from the notion of legal personality) undoubtedly had a significant effect on influencing the essence of Afro-European relations in the Americas and (ultimately) on shaping the nature of the languages that developed from such contact.

\subsubsection{Back to Peru}

The same kind of observers' comments and court cases reported in Sections 6.3.1 and 6.3.2 to testify to the effects of legal personality on the living conditions of Spanish slaves across the Americas can easily be encountered for Peru as well. For example, the British traveler Stevenson (1828:42-43; cf. Andres-Gallego 2005: 273), who spent some twenty years in the Americas during the first decades

42. Schwegler (p.c.) does not agree with this claim. He thinks that this does not explain why slaves would escape, if it is true that they had inalienable rights. At this point I wish to punctualize that the sociohistorical evidence we have indicates that, overall, the Spanish system provided slaves with more rights and chances for integrations than any other European system. This is not to say that Spanish slaves had a great life, thus it is understandable that they might have tried to run away. 
of the 19th century, indicated that the way slaves were treated in Peru was much better than in any other country he had ever visited. He even stated that Peruvian slaves lived better than many European farmers in the Old World. He used the following words to describe the condition of black slaves on Peruvian plantations:

Si les esclaves de tous les pays pouvaient être traités de la même manière que ceux que j’ai été a portee de voir au Pérou, pendant le séjour que j’y ai fait, leur sort serait, sans contredit, plus heureux que celui de beaucoup de paysans de l'ancient monde.

(If the slaves in all the countries could be treated the way I saw people treat them in Peru, they would be, without any doubt, better off than many farmers working in the Old World).

Obviously, these remarks should be taken with a grain of salt. In fact, given the cases we know of mistreatment (cf. Andres-Gallego 2005:176-185), it is hard to believe that Peruvian slaves working on plantations had such a great life. Nevertheless, if we analyze these words considering the perspective of a European man who traveled for several years across English, French and Spanish colonies in the Americas at the beginning of the 19th century, we may infer that overall the Peruvian slave had a much better life than black captives working on either English or French plantations.

In addition, if we examine the court cases concerning slavery for colonial Peru, we can easily find all the typologies of legal actions related to the presence of slaves' legal personality, as we found for the other Spanish colonies. Peru, in fact, was one of the Spanish Viceroyalties in the Americas, it was an important colony and administrative hub in the Spanish Empire; for this reason, colonial archives are replete with legal documentation and slavery-related trials have been brought to light and studied by several historians focusing on colonial Latin America (cf. Lockhart 1968; Bowser 1974; Lucena Salmoral 2000a; Andrés-Gallego 2005; etc.). Indeed, the socioeconomic and legal dynamics that emerged in Chapter 5 of this book, when we described the slaves' living conditions in colonial Peru, appear to parallel perfectly the overall scenario encountered in the rest of the Spanish colonies, as testified by the cases reported in Section 6.3.2. Therefore, the same kind of situations picturing slaves involved in legal actions over property rights, manumissions, marriages, mistreatments, etc. can be easily encountered. For example, we mentioned the case of Juan de Fregenal, a black man who purchased his freedom and then became a successful business man (cf. Lockhart 1968: 194195); the group of black freedmen who managed to acquire lands in Carabaya and became hacienda owners (cf. Lockhart 1968:192); the trial started by José de la Trinidad, who sued his master because of the excessively harsh working conditions he imposed on him (cf. Andres-Gallego 2005:208); or the example of 
Domingo Barrueta, who forced his owner to sell him so that he could live close to his wife (cf. Andres-Gallego 2005:211). These are only some among the many cases that could be cited (for a more detailed account cf. Lockhart 1968; Bowser 1974; Lucena Salmoral 2000a, b; Andrés-Gallego 2005).

These data show that in Peru the socioeconomic and legal dynamics of slavery did not diverge much from the general patterns found in other Spanish colonies overseas. Nevertheless, this system - quite homogeneous within the Spanish Empire - significantly differed from the legislations found in other European colonies. This marked contrast, which eventually boils down to the presence/absence of slaves' legal personality, represents a crucial factor to explain the reasons behind the genesis and evolution of Afro-European contact varieties in the Americas.

\subsubsection{Three case studies to test the Legal Hypothesis of Creole Genesis}

This section provides an analysis of some case studies that may be used as a powerful testing ground for the Legal Hypothesis of Creole Genesis: post-sugar-boom Cuba, seventeenth century South Carolina and Barbados, and seventeenth century Chocó (Colombia). Before proceeding to the analysis of these scenarios, I must stress one more time that this hypothesis is not claiming that slaves' legal personality is the only reason why Spanish creoles did not develop in Spanish America; the Legal Hypothesis of Creole Genesis, in fact, does not deny the fact that demographic, economic and logistic factors played a major role in shaping colonial societies and their languages. What this hypothesis is actually claiming is that an additional factor that should be added to the aforementioned list is the legal one. Indeed, this factor set Spain apart from the other European colonies involved in the colonization of the Americas and had obvious effects on the evolution of colonial social and linguistic dynamics.

\subsubsection{Cuba}

As observed in Section 2.3, Clements (2009:68-101) has recently provided a linguistic perspective on the evolution of Cuba's colonial economy and demographic figures during the colonial period. He showed - in line with Mintz (1971), Laurence (1974), and Lipski (1993) - that until the 1810 the country's production system was primarily based on small haciendas, which did not rely massively on enslaved labor force. Nevertheless, after the sugar boom of the nineteenth century, a shift in the terms of production took place, so that a plantation system requiring a high number of African slaves was implemented. Additionally, given the reported cases of widespread violence (cf. Blackburn 1997), it has been suggested that "the brutal exigencies of sugar cultivation obliterated any significant affection 
or clemency towards black slaves" (McWhorter 2000:36). So, if the sugar boom of the nineteenth century had turned Cuba into a plantation society similar to those found in Haiti and Jamaica, why is it that we do not find a Spanish creole in Cuba, but we do find creoles in the former French and English colonies? And how can the Legal Hypothesis help us understand this situation?

To answer these questions, it is important to analyze the socio-historical scenario that preceded the sugar boom. In fact, it has been shown that besides an exception for a short period around 1532, blacks never outnumbered whites in Cuba until 1811 (Masó 1976: 115; Clements 2009:77). Clements (2009:81) indicates that the restrictions on slave trading imposed by the Spanish crown highly constrained the introduction of African slaves into the island for several centuries so that the local economy had to rely primarily on the sectors that did not need much workforce, such as tobacco and cattle raising. Moreover, besides the demographic factor, Clements points out a few other elements that may have reduced the likelihood of creole formation on the island; in particular he stresses the presence of a higher numbers of manumissions and the emphasis placed by the Spanish authorities on Catholic education, which indirectly implied language teaching.

Therefore, a prior stage of société d'habitation would have favored language acquisition among the black workers (Chaudenson 2001); when the sugar boom imposed a large-scale plantation system, the recently arrived masses of African slaves did not creolize the Spanish spoken in Cuba; rather, the new bozales, who were numerically inferior to the local population, just learned the language spoken by the slaves who were already working on the islands (Lipski 1993, 1998). In line with what shown by Mintz (1971) and Laurence (1974), these socio-economic data may account for the non-creolization of Cuban Spanish. But how can we gain any additional insights by focusing on the different European slave laws at a time when Cuban law in books may have differed from Cuban law in action?

It must be said that an economic shift in the manner of production (from a system of small farms to one of big plantations) did not necessarily imply a complete change in the social and cultural habits of the people living on the island. To be sure, neither did it completely dismiss all the rights related to slaves having legal personality, nor did it remove the acceptability of mixed-race people in society (Watson 1989; Andrés-Gallego 2005). Indeed, even after the sugar boom, the Spanish Caribbean differed quite significantly from the English and French Caribbean societies.

Self-purchased manumission, coartación, was still in place in colonial Cuba, even after the sugar boom (Lucera Samoral 2005; Andrés-Gallego 2005). It must be stressed that the practice of manumission did not necessarily have much to do with a "kinder, gentler" attitude; it had been designed in Roman times as an incentive to work harder. When a slave was manumitted, his Spanish master did not 
lose any money since the amount paid would be enough to buy another captive. What is more; the incentives generated by this legal instrument in the workforce were definitively beneficial to the owner; the reasons why such a practice was so restricted by the English and French legislations had more to do with the fact that those systems were more concerned with regulating the public sphere of slavery than the Spanish one, they were much more segregated and strictly forbade interracial mixing. On the other hand, even after the sugar boom, it was common for white men and black women to have intimate relations and mixed-race marriages were not exceptional, such that a free mulatto group, capable of speaking Spanish, kept growing.

Even though Christianizing all the recently arrived bozales was not an easy task, and in certain cases proved impossible (cf. Andrés-Gallego 2005:117), certain legal and social practices promoted by the Catholic Church (i.e. slave marriage; family preservation; etc.) were so deeply rooted in society that attempting to break such social conventions would have caused major turmoil. This is not only true of the Cuban sugar boom; it can be observed in a variety of other AfroHispanic contexts. When the Company of Jesus in 1767 was expelled from the Spanish colonies, it had to leave behind its haciendas and its slaves. Those properties were subsequently dismantled and sold to individuals. It is well known that the riots that took place in Chota Valley (Ecuador) and Chincha (Peru) in those years were the result of the irresponsible actions of certain government administrators who tried to sell individual slaves to the highest bidders without taking into account the family rights that had been bestowed upon those communities for centuries (Sessarego 2013a, 2014c). The sudden attempt to remove a right taken for granted by society inevitably led to social unrest.

As a result of this Hispanic legal and cultural heritage, even after the sugar boom, the hierarchical structure of society in Cuba was much more flexible than that found in the French and English territories and, for this reason, Spanish slaves could more easily climb the social ladder. Even though the Cuban economic system eventually became more similar to the one in place in French Haiti and English Jamaica, its Spanish social conventions and cultural habits - rooted and reflected in the Spanish law - did not converge with the English and French ones.

In summary, the evolution of slavery and its legal codification within the Spanish system had a deep effect on the development of Spanish society for centuries. A rapid change in the means of economic production in the nineteenth-century Spanish Caribbean did not wipe away such a cultural background. It definitely imposed stricter constraints on the practical fruition of some rights (i.e. manumission might have been more difficult to achieve), but it could not remove certain customs that belonged to society (i.e. slave marriages, family preservation, coartación, etc.) and the legal principles on which they had been based (i.e. slaves' 
legal personality). This legal and cultural heritage, combined with the fact that the Cuban economy had been based for centuries on a system of small farms, did not lead to the development of a Spanish creole on the island during the sugar-boom phase of the nineteenth century.

\subsubsection{Barbados and South Carolina}

McWhorter (p.c.) claims that the Legal Hypothesis of Creole Genesis makes a scientific prediction: that in colonies where criollos were common, no creole occurred. He indicates that such a prediction cannot be accepted unless it is first tested. He proposes South Carolina as a testing ground since it is well known that a large proportion of the founding slaves brought to Charleston were from Barbados that is, many of them had been born in the New World. Yet there is a creole there, Gullah - why did those criollos from Barbados speak a creole?

These are interesting points, which I would like to address in order to clarify potential doubts that the proposed hypothesis may generate. First of all, I wish to highlight that the Legal Hypothesis of Creole Genesis does not make any prediction on the criollo vs. bozal issue. As I have already indicated in this chapter, this hypothesis stresses the importance that the different legal systems had in shaping colonial societies and their languages; it does not address demographic issues such as whether slaves were born in Africa or in the Americas. This being said, I personally believe that demographic issues such as the criollo vs. bozal distinction are key to understanding the genesis and evolution of Afro-European languages in the Americas. Thus, in line with the Founder Principle (Mufwene 1996), I do think that a large proportion of the structure of today's contact languages was determined by the make-up of the founder populations. This does not mean that criollos equals Spanish dialect, while bozales equals Spanish creole; it just means that if the founder population speaks a creole or speaks African languages and has little access to the European language, than a creoloid vernacular is more likely to be adopted by the community; while if the founder population already speaks a good approximation to the superstrate language or a minority speaks African languages and has good access to the European lexifier, then a creole language is less likely to develop and to be adopted by the enslaved group. In a society like pre-sugar-boom Cuba, where bozales supposedly had good access to Spanish, black captives could learn a good approximation to Spanish and a creole did not emerge; their offspring, which technically were criollos, acquired Spanish as their L1. Conversely, in other colonial settings (i.e. Jamaica or Haiti), even locally-born plantation slaves may have had little access to the European language, thus they acquired a creole as their native language.

Even though the criollo vs. bozal distinction is not directly related to the Legal Hypothesis predictions, the presence of a creole language supposedly proceeding 
from Barbados in South Carolina may serve as a good testing ground for this model. McWhorter (2000:107-108) claims that "plantations were small in Barbados as well until 1665"; thus, this would indicate - in his view - that the living and working conditions of slaves in Barbados were comparable to those of slaves in pre-sugar-boom Cuba. Consequently, if a creole did not develop in Cuba, then it should not have developed in Barbados either. According to McWhorter, such a creole must have arrived to Barbados from somewhere else: West Africa.

It is here where the Legal Hypothesis of Creole Genesis clashes with the Afrogenesis Hypothesis. The Legal Hypothesis of Creole Genesis predicts that, even in similar demographic settings, the life of a slave in Spanish America differed quite significantly from the life of a slave in English America. The South Carolina and Barbados examples are particularly well-suited for this test. Indeed, as I have indicated in Section 6.2.3, the South Carolina statute on slavery from 1690, called the "Act for the Better Ordering of Slaves", was in great part borrowed from the statute of Barbados of 1688 (Watson 1989:68-69). All the rights that legal personality provided to slaves in the Spanish colonies were strictly forbidden in these two English-controlled regions: slaves could own no property, no peculium was allowed, they could not marry, family members could be sold as individual tokens, slaves could not sue their masters, no racial mixing was allowed, etc. Moreover, in the original statutes of Barbados and South Carolina manumission was not even an option. Additionally, the states strongly intervened in the regulation of the public life of slaves: slaveholders could not provide their slaves with extra benefits beside those allowed by the law, pre-established punishments had to be inflicted in case of disobedience, etc. If it is correct to say that the Spaniards were not any kinder or gentler to their slaves, it is also right to state that the intervention of the English legislators was definitely crueler and rougher.

Given the radically different social dynamics entailed by these divergent slave laws, it is no surprise that the Barbadian and South Carolinian societies may have been more conducive to creolization and/or preservation of creoles than the $\mathrm{Cu}$ ban one. While I have some serious doubts about the possibility that virtually all English-based creoles and French-based creoles would have developed from one French and one English pidgin (from the Île the Bieurt, Senegal, and Cormantin Castle, Ghana, respectively) (McWhorter 2000:111,173), I do not deny that certain contact vernaculars may have spread from one region to another and that certain plantations did not necessarily create creoles but preserved them (McWhorter 2000:205). On this specific issue, I think, some points of convergence may be encountered between the Afrogenesis Hypothesis and the Legal Hypothesis. Indeed, the Legal Hypothesis may help explain why certain colonial settings might have been more likely to preserve creoles than others (i.e. providing incentives/motivations to learn the European language and/or the creole). What I find limiting 
about the Afrogenesis Hypothesis is the assumption that only African-born pidgins may have seeded the American land to grow into fully-developed creoles, and that virtually no qualitative difference among colonies would play a role in the creolization process, thus basically implying that no significant dissimilarities existed among slaves' living conditions across the different European territories in the Americas.

\subsubsection{Chocó}

Chocó Spanish is spoken by the descendants of the slaves taken to the Colombian Pacific lowlands during colonial times to work the rich gold mines of the area. The socio-historical scenario that characterized colonial Chocó seems to have been ideal for a full-fledged creole language to develop: a low whites to blacks ratio, harsh working conditions in labor intensive mines, massive introduction of African-born workers, and minimal access to the outside Spanish speaking world (McWhorter 2000: Ch. 2). For this reason, McWhorter claims that this is the prototypical "missing Spanish creole", which would prove that creoles were not created on American plantations/mines due to the lack of access to the European lexifier; since, "if they were, Chocoanos would speak a creole" (McWhorter 2000:205).

This region offers another valuable testing ground for the Legal Hypothesis; in fact, Chocó Spanish developed in an area described by many as 'remote' and 'on the frontier' (cf. Whitten 1974; Sharp 1976), thus far away from legal courts and where law was not likely to be properly enforced. So, why do we not find a Spanish creole in Chocó? Did the Spanish legal tradition play any significant role?

Again, as in the Cuban case, the Legal Hypothesis does not deny the importance of other economic, logistic, and demographic factors. Thus, to understand why Chocoanos speak a dialect of Spanish rather than a Spanish creole, a brief socio-historical analysis is due.

The colonial and post-colonial history of Chocó is strongly connected to the socio-political development of its surrounding regions. In fact, the powerful colonial miners residing in Antioquia, Cali and Popayán were those who pushed the Spanish colonial enterprise toward this remote frontier - conquering and exploiting the region, which was one of the richest mineral areas of the Americas. In particular, the principal actors in this conquering enterprise were the mining families from Popayán, who, after several attempts to penetrate the region, finally managed to defeat and pacify the native populations by the end of the seventeenth century. From that point until the abolition of slavery in 1821, several white and mestizo entrepreneurs entered the region with their gangs of black slaves (cuadrillas) to exploit the rich gold mines of the province (Sharp 1976).

McWhorter (2000:7-10) maintains that, if we believe the limited access model, Colombian Chocó would have been the perfect place for a Spanish creole to 
develop. He supports this claim by reporting demographic data that indicate that by 1778 the ratio of blacks to whites was $5,828: 175$; thus the whites represented just 3 percent of the entire population (West 1957: 100,108). This piece of information - at first glance - may appear to suggest that access to Spanish must have been very limited; however, a closer look at the available socio-historical evidence indicates the exact opposite. In fact, the ratio blacks to whites does not tell us much about the languages spoken by those two ethnic groups. For example, it would be a mistake to assume that the blacks in Chocó were all bozales who spoke African languages. On the contrary, from the very beginning of the mineral exploitation of the region, the Spaniards brought with them the slaves they had used in previous mining enterprises (Colmenares 1997; Bryant 2005). Mining was not an easy job, and a certain number of experienced slaves, capable of understanding Spanish, was always required. Such a practice was not only found in the mining sector, indeed, as we saw for the Peruvian case, in the plantation business, skilled criollos were also commonly transferred from hacienda to hacienda (Flores Galindo 1984: 28; Sessarego 2014c: 102), in line with the logic behind the supposed relocation of Barbadian slaves to Suriname and South Carolina (McWhorter 2000: 107). In addition, if we pay attention to slave transactions in Popayán, the biggest slave market of the Andes (Bryant 2005), we immediately discover that during the peak of the Chocó mineral exploitation (1690-1780), almost $60 \%$ of all the captives sold in Popayán were criollos, thus they did not proceed directly from Africa and were probably speaking good approximations of Spanish (Colmenares 1997). The sales of criollos and mulattos, in fact, were far more common in Popayán and in Chocó than in Cartagena (the biggest slave market in Spanish Americas receiving captives directly from Africa), especially when the supply of bozales was low: for example between 1690 and 1701, during the Succession War (1705-1710) and when there were interruptions with the supply of licenses (1715-1720, 1740-1745 and 1753-1759) (Colmenares 1997:57).

As a result of this brief historical inquiry, I think we have enough evidence to cast some serious doubts on the analyses that depict Chocó as the perfect breeding ground for a Spanish creole to develop, at least if we consider the demographic factor. At this point, however, I would also like to show how the legal factor may have played an important role in shaping certain social, and - consequently - linguistic, dynamics in this remote region.

The historian William Sharp (1976) wrote an entire book on Chocó slavery: Slavery on the Spanish Frontier: The Colombian Chocó 1680-1810. One of the main goals of this manuscript is to test Frank Tannenbaum's (1946) claim that "slavery, as it existed in Latin America, was generally a milder institution than the systems practiced by other European colonial powers in the New World" (Sharp 1976:5). One of the weaknesses of this proposal, as pointed out by some scholars working 
Table 6.1 Slaves sold in Popayán 1690-1789 (\% according to their age) (Colmenares 1997:36)

\begin{tabular}{ccc}
\hline Ages & Criollos (1,074 cases) & Bozales $(\mathbf{7 4 9}$ cases $)$ \\
\hline $0-5$ & 7.0 & 0.2 \\
$6-11$ & 13.5 & 2.8 \\
$11-15$ & 22.3 & 25.5 \\
$16-20$ & 27.9 & 39.9 \\
$21-25$ & 14.8 & 16.7 \\
$26-30$ & 10.0 & 9.2 \\
$31-35$ & 1.8 & 2.9 \\
$36-40$ & 2.6 & 2.7 \\
Total & 100 & 100 \\
$\%$ & 58.9 & 41.1 \\
\hline
\end{tabular}

in the field of slavery in the Americas (i.e. Elkins 1959), was that Tannenbaum's analysis was primarily based on a legalistic approach, which completely lacked empirical archival investigation to understand to what extent "law in books" was reflected by "law in action". Therefore, to test such a claim, Sharp selected Chocó, one of the most remote regions of Latin America, where law enforcement was probably minimal. Sharp (1976:127-145) dedicates an entire chapter to this issue: Slavery in Chocó: Law and Reality. He begins this chapter by stating that Tannenbaum's proposal was based on two main claims: (1) the Spanish legal system had in place a variety of regulations concerning manumission, marriage, family issues, punishments, law suits against the masters, etc. that would protect slaves against potential abuses; (2) the Catholic Church actively intervened in the relationships between masters and slaves, thus improving the captives' living conditions since "masters were admonished to protect the moral welfare of their slaves and see to their spiritual instruction” (Sharp 1976: 130).

Sharp strongly affirms that both conditions were missing in Chocó. On the one hand, slaves in Chocó could not receive much legal protection against abuses since the population in the area was too small to justify the expenses of sending government administrators into the region to systematically enforce regulations (Sharp 1976:128, cf. McWhorter 2000:37) while, on the other hand, there were very few clerics (only eighteen priests in a total population of 17,898 in 1789), to effectively have any significant effect on improving captives' living conditions (Sharp 1976:131, cf. McWhorter 2000:37). Nevertheless, a close analysis of the archival documentation available from the mining enterprises, including the local registers for manumission, marriages, etc., as well as the slave codes provided by the owners to the administrators to maintain order in the cuadrillas, indicates that all the basic slave rights derived by the notion of legal personality were 
fundamentally preserved in Chocó. In fact, slaves worked in average 260 days a year, since during the remaining time they were off (a sort of peculium) to provide for themselves and their families (1976:134); they could accumulate goods, gold and other properties to pay for their manumission (1976:135), abuse of slaves was remarkably rare (1976:136), they were instructed in the precepts of the Catholic religion (1976:139), marriage was encouraged and family units preserved (1976: 140). Sharp stresses that these cultural habits, stated in the local slave codes and implemented by the administrators in their cuadrillas should not make us believe that the Spanish miners were gentler or kinder. On the contrary, "far from exhibiting human, legal, or religious values, the Chocó slave codes were very pragmatic" (1976: 140). Indeed, religion was seen as a tool to stress obedience as a Christian value; marriage and family preservation was a way of binding the slave to the mine, since escaping was much more difficult with a wife and children; providing captives with the means to feed themselves was a basic prerequisite if the owner wanted the slaves to be healthy and productive. All in all, better treatments also reduced the likelihood of black rebellions, which such a small white minority had to prevent as much as possible (1976:141). These social dynamics, combined with the wealthy Chocó gold resources, provided black captives with incentives and opportunities to achieve manumission and thus become free people. Sharp (1976: 141-142) clearly states that:

Manumission in Chocó was not only possible but occurred. In 1778, 35.44 per cent of the black population was free $(3,160$ of 8,916$)[\ldots]$. During the next thirty years the free black population increased by a remarkable 5.7 per cent a year. By 1808, 75.34 per cent of the black population in the Chocó was free.

Once again, we may observe that certain legal rights were so rooted in the Spanish colonial society that, even if no legal enforcement was effective in Chocó, those rules were for the most part respected as they belonged to social praxis. Indeed, what would have been the incentives for any rational slave-owner not to respect the aforementioned practices reported in the local slave codes and belonging to the local customs?

Sharp $(1976: 142,147)$ concludes his analysis by saying:

It may be argued that the treatment designed for slaves in Chocó followed the pattern described by Tannenbaum [...], even though the Spanish legal system and the church were not directly involved [...].

Slaveholders in Chocó understood the formula that better physical treatment resulted in healthier workers and greater productivity. Mistreatment led to dissatisfaction and possible rebellion. Profit motives helped determine slave treatment but ironically, behavior was in general accord with the Spanish conduct Tannenbaum [...] described. 
If we look at colonial Choco through the lenses provided by the Legal Hypothesis of Creole Genesis, and we combine the resulting image with the available demographic evidence we have for this region, we may now better understand why Chocoanos speak a Spanish dialect rather than a Spanish creole.

\subsection{The Legal Hypothesis of Creole Genesis in the context of Afro-European contact varieties in the Americas}

This chapter has brought attention to the nature of slavery in colonial Americas to cast some light on the Spanish creole debate. In order to approximate this goal, I decided to focus on the legal systems that regulated black captivity overseas. Findings indicate that the reasons for such a heterogeneous legislation must be sought back in Europe, where the bases of slave law were originally laid down by the Romans. In fact, this study shows that the juridical figure of the 'serf/slave' had been received by the Spanish legal system in ancient times, from the Roman Corpus Juris Civilis; it had been gradually modified and progressively softened into the medieval Spanish code, called Siete Partidas, and then further smoothed in the Leyes de Indias 'colonial laws'. In particular, the Spanish slave, unlike the Roman one, was granted legal personality and a series of legal rights that derived from it. On the contrary, the juridical concept of 'serf'/'slave' followed a significantly dissimilar evolutionary path in the other European codifications, which did not receive it in ancient Roman times. Thus, by the time the Americas were "discovered", the English, the French and the Dutch found themselves borrowing directly from the Corpus Juris Civilis to fill such a legal gap and introduced slaves into their overseas plantations. As a consequence, English, French and Dutch slaves did not have legal personality and the living conditions set by these legal systems for black captives were much more brutal than the ones dictated by the Spanish Crown (Watson 1989; Andrés-Gallego 2005). The Portuguese, on the other hand, had received Roman slave law in ancient times but over time did not modify it to the extent the Spaniards did. As a result, Brazilian slaves were not considered legal persons, and had many more restrictions constraining their freedom than Spanish slaves did.

The Legal Hypothesis of Creole Genesis does not pretend to be the answer to all the questions that gravitate around the Spanish creole debate. As I have indicated, a variety of demographic, economic, political, religious and social factors played a role in the evolution of the Afro-European contact varieties that developed in the Americas, and they should not be dismissed for the sake of a simpler/ more elegant creole equation (i.e. no slave castles in Africa $=$ no creole languages 
in the Americas). Nevertheless, this proposal clearly identifies an important common feature that Peru and all the remaining Spanish colonies overseas shared, in contrast to the other European territories (presence vs. absence of slaves' legal personality); thus it provides a reasonable generalization that addresses the puzzle concerning such a "mysteriously absent creoles cluster under a single power" (McWhorter 2000:39).

The Legal Hypothesis of Creole Genesis highlights the impact that these legal differences had on the development of black-white relations and therefore on the evolution of contact varieties in the Americas. In particular, it stresses the importance of the reception of Roman slave law in Europe as a significant factor for understanding the evolution of Afro-European languages in the New World. The point that is here conveyed might be summarized as follows: if certain colonial societies in the Americas were more or less conducive to creolization than others, it is in great part due to the degree of legal Romanization their homeland countries went through in ancient times. 



\section{CHAPTER 7}

\section{Concluding remarks}

The origins of the Afro-Hispanic dialects of the Americas are extremely intriguing, since it still has to be explained why we do not find creole languages in certain regions of Spanish America, where - at first glance - the socio-demographic conditions for creole languages to emerge appear to have been in place in colonial times.

Different hypotheses have tried to cast light on this issue. On one hand, the supporters of the Decreolization Hypothesis have suggested that a Spanish creole may have existed in several Latin American regions, and that it would have subsequently decreolized due to recent contact with more prestigious Spanish varieties (Granda 1968, 1970; Schwegler 1999, 2014; etc.). On the other hand, other scholars have indicated that - at least for the Caribbean region - the socioeconomic factors were not present in colonial times for the development of a Spanish-based creole, since the sugar boom hit the Spanish Caribbean only in the 19th century, when a Spanish dialect was already spoken by the vast majority of the free and enslaved populations (Mintz 1971; Laurence 1974; Lipski 1993; Chaudenson 2001; Clements 2009; etc.). More recently, McWhorter (2000) has proposed in his book, The Missing Spanish Creoles, the Afrogenesis Hypothesis, which claims that for coastal Peru and several other Mainland regions of Spanish America the conditions for the evolution of a creole language were perfectly in place and that if a Spanish creole did not emerge, it is because a Spanish pidgin was not spoken in Africa, so that it could not possibly be transplanted to the Americas and turned into a fully-fledged creole.

According to McWhorter, plantation creoles did not form because slaves had little or no access to the superstrate language (what he calls "the limited access model"); rather, the reason why creoles developed had to do with the fact that Africans decided to create new means of communication, different from the languages spoken by their masters, which came to represent a symbol of black identity for the slaves working in the fields. McWhorter (2000) argues that "the limited access model" has a main fault: it cannot explain why Spanish-based creoles are not spoken in Spanish America. In his view, in fact, "something broader was at work [in Spanish America] than just unconnected, local demographic constellations" (2000:39). 
McWhorter's proposal has been tested and criticized by several authors who worked on some of the Afro-Hispanic dialects he classified as "missing Spanish creoles" (cf. Díaz-Campos \& Clements 2005, 2008 for Barlovento Spanish; Sessarego 2013a, c, 2014b for Chota Valley Spanish); nevertheless, his effort to provide a unified framework to account for creole genesis has generally been praised (cf. Schwegler 2002: 121; Lipski 2005: 286).

The current study has paid close attention to yet another Mainland Latin American region identified by McWhorter as the perfect breeding ground for a Spanish creole to develop, coastal Peru. The overall picture emerging from the available data seems to suggest that Afro-Peruvian Spanish (APS) was neither a creole which decreolized (contra the Decreolization Hypothesis) nor a 'missing Spanish creole' (contra the Afrogenesis Hypothesis). In fact, the main linguistic features detected for APS, which have also been traditionally reported for AfroHispanic vernaculars in relation to their potential creole origin (i.e. overuse of subject pronouns, invariant verb forms, lack of gender and number agreement across the DP, lack of subject-verb inversion in questions, presence of bare nouns), can be accounted for as cases of advanced second language acquisition strategies, which do not necessarily imply a previous (de)creolization stage.

On the other hand, the available socio-historical evidence encountered for this vernacular casts some serious doubts on colonial coastal Peru as the ideal environment for a creole language to develop. Indeed, a number of factors appear to have contributed to the non-creolization of Peruvian Spanish in the region. Data show that the logistic and economic restrictions on slave trading did not allow for the massive introduction of Africans into the colony. In particular, during the first colonial phase (1500-1650), slaves' introduction happened gradually, and blacks were usually ladinos proceeding from Spain or other settled colonies (Lockhart 1968). Even during the second phase (1650-1767) the importation of bozales in Peru did not achieve a massive volume. Moreover, the presence in the country of a large number of criollo slaves, combined with their systematic use on coastal sugarcane plantations (Flores Galindo 1984), certainly reduced the likelihood of a Spanish creole emerging in this area, in line with Mufwene's (1996) Founder Principle.

Not many planters had the economic resources to rely on a massive black labor force, the only organization that had the required financial means to do so was the Catholic Church, and in particular the Company of Jesus. Nevertheless, we observed that even in the biggest Jesuit haciendas the introduction of new slaves was neither abrupt nor massive (Cushner 1980), while the managerial techniques used by this religious organization to increase production and Christianize the enslaved workers were likely to have favored the acquisition of Spanish by the black captives (Macera 1966). These patterns also applied to the specific 
plantations analyzed for the current study in Chincha, where the haciendas used to belong to the Company of Jesus before being confiscated by the Temporalidades council in 1767 and sold to private landowners.

The present work not only contributes to shedding light on the origins of APS, it also helps clarify the controversial puzzle concerning the genesis of Spanish creoles in the Americas in a broader sense. In order to provide a more concrete answer to the question raised by McWhorter on a "mysteriously absent creoles cluster under a single power" (2000:39), the current study has focused on an aspect of the European colonial enterprise in the Americas that has never been closely analyzed in relation to the evolution of Afro-European contact varieties, the legal regulations of black slavery.

In fact, Spain not only diverged from other European powers in that it did not directly trade in African slaves, as highlighted by McWhorter (2000); rather, one additional peculiarity of the Spanish colonial enterprise is found in its legal regulation of black slavery. In particular, due to a concomitance of several historical facts (i.e. early reception of the Corpus Juris Civilis, pressure exerted by the Catholic Church on society, etc.), Spanish slaves in medieval times obtained legal personality, which implied that Spanish captives in the Americas had a variety of rights completely unknown to - or highly constrained for - the slaves living under other European rules. All these elements significantly affected the essence of Afro-European social dynamics in the different American colonies, and consequently the nature of the languages that developed from such divergent social contexts. These ideas form the core of the Legal Hypothesis of Creole Genesis, which ascribes a prime importance in the development of Afro-European languages in the Americas to the historical evolution of slavery, from the legal rules contained in the Roman Corpus Juris Civilis to the codes and regulations implemented in the different European colonies overseas.

This book has provided a linguistic and socio-historical account of APS to shed light on its nature and origin. At the same time, the current volume has departed from the analysis of this specific Afro-Hispanic dialect to offer a broader perspective on the status and evolution of Black Spanish varieties in the Americas. As far as the linguistic status of these vernaculars is concerned, it has been suggested that they may be classified as advanced conventionalized second languages, or L1 varieties that present crystallized aspects of advanced L2s. As for their genesis and evolution, this research was carried out with the belief that creole studies will benefit greatly from a more interdisciplinary approach, capable of combining linguistic, socio-historical, legal, and anthropological insights. This study is meant to represent an eclectic step in such a direction. 



\section{References}

Adger, D. \& Smith, J. 2005. Variation and the minimalist program. In Syntax and Variation. Reconciling the Biological and the Social [Current Issues in Linguistic Theory 265], L. Cornips \& K.P. Corrigan (eds), 149-178. Amsterdam: John Benjamins.

DOI: $10.1075 /$ cilt.265.10adg

Aguirre Beltrán, G. 1946. La población negra en México: Estudio etnohistórico. México DF: Ediciones Fuente cultural.

Aguirre Beltrán, G. 1958. Cuijla: Esbozo etnográfico de un pueblo negro. México DF: Fondo de Cultura Económica.

Aguirre, C. 1993. Agentes de su propia libertad. Los esclavos de Lima y la desintegración de la esclavitud, 1821-1854. Lima: Pontificia Universidad Católica del Perú.

Aguirre, C. 1997. Peru. In The Historical Encyclopedia of World Slavery, J. Rodríguez (ed.), 501502. Santa Barbara CA: ABC-CLIO.

Aguirre, C. 2005. Breve historia de la esclavitud en el Perú: Una herida que no deja de sangrar. Lima: Fondo Editorial del Congreso del Perú.

Alleyne, M. 1980. Comparative Afro-American: An Historical-Comparative Study of EnglishBased Afro-American Dialects of the New World. Ann Arbor MI: Karoma.

Álvarez Nazario, M. 1974. El elemento afronegroide en el español de Puerto Rico, 2nd edn. San Juan: Instituto de Cultura Puertorriqueña.

Álvarez, A. \& Obediente, E. 1998. El español caribeño: Antecedentes sociohistóricos y lingüísticos. In América negra: Panorámica actual de los estudios lingüísticos sobre variedades hispanas, portuguesas y criollas, M. Pearl \& A. Schwegler (eds), 40-61. Frankfurt/Madrid: Vervuert/Iberoamericana.

Andersen, R. 1980. Creolization as the acquisition of a second language as a first language. In Theoretical Orientations in Creole Studies, A. Valdman \& A. Highfield (eds), 273-295. San Diego CA: Academic Press.

Andersen, R. (ed.). 1983. Pidginization and Creolization as Language Acquisition. Rowley MA: Newbury House.

Andrés-Gallego, J. 2005. La esclavitud en la America española. Madrid: Ediciones Encuentro.

Andrien, K. 1995. The Kingdom of Quito, 1690-1830: The State and Regional Development. Cambridge: CUP. DOI: 10.1017/CBO9780511529054

Arrelucea, M. 2004. Esclavitud, género y visibilidad: Cimarronas y bandoleras en lima colonial, 1760-1820. Ms.

Ansaldo, U. 2009. Contact Languages: Ecology and Evolution in Asia. Cambridge: CUP. DOI: $10.1017 /$ CBO9780511642203

Baker, P. \& Bruy, A. (eds). 1999. St. Kitts and the Atlantic Creoles: The Texts of Samuel Augustus Mathews in Perspective. London: University of Westminster Press.

Baptista, M. \& Guéron, J. (eds). 2007. Noun Phrases in Creole Languages [Creole Language Library 31]. Amsterdam: John Benjamins. DOI: 10.1075/cll.31 
Béjar, S. 2008. Conditions on Phi-Agree. In Phi-theory, D. Harbour, D. Adger \& S. Béjar (eds), 130-154. Oxford: OUP.

Bentley, W.H. 1887. Dictionary and Grammar of the Kongo Language as Spoken at San Salvador, the Ancient Capital of the Old Kongo Empire, West Africa. London: Baptist Missionary Society and Trübner \& Co.

Benvenutto Murietta, P. 1936. El lenguaje peruano. Lima: Talleres de Sanmartí y cía.

Berlin, I. 1997. Many Thousands Gone: The First Two Centuries of Slavery in North America. Cambridge MA: Harvard University Press.

Birdsong, D. 1992. Ultimate attainment in second language acquisition. Language 68: 706-755. DOI: 10.1353/lan.1992.0035

Blackburn, R. 1997. The Making of New World Slavery: From the Baroque to the Modern, 14921800. New York NY: Verso.

Blackstone, W. 1765[2003]. Commentaries of the Laws of England. Oxford: Clarendon Press.

Blanchard, P. 1992. Slavery and Abolition in Early Republican Peru. Wilmington DE: Scholarly Resources.

Boschetti, A. 2006. Un océano en su mochila. Lima: Stampa Gráfica.

Bouisson, E. 1997. Esclavos de la tierra: Los capesinos negros del Chota-Mira, siglos XVII-XX. Procesos, Revista Ecuatoriana de Historia 11: 45-67.

Bourne, E.G. 1904. Spain in America, 1450-1580. New York NY: Harper \& Brothers.

Bowser, F. 1974. The African Slave in Colonial Peru, 1524-1650. Stanford CA: Stanford University Press.

Boyd Bowman, P. 1968. Regional origins of Spanish colonists of America: 1540-1559. Buffalo Studies 4: 3-26.

Brockington, L. 2006. Blacks, Indians, and Spaniards in the Eastern Andes. Lincoln NB: University of Nebraska Press.

Bruhn de Garavito, J. \& White, L. 2000. L2 acquisition of Spanish DPs: The status of grammatical features. In Proceedings of the 24th Annual Boston University Conference on Language Development, S. Catherine Howell, Sarah A. Fish \& Thea Keith-Lucas (eds), 164-175. Somerville MA: Cascadilla Press.

Bryant, S. 2004. Enslaved rebels, fugitives, and litigants: The resistance continuum in colonial Quito. Colonial Latin American Review 13(1): 7-46. DOI: 10.1080/1060916042000210800

Bryant, S. 2005. Slavery and the Context of Ethnogenesis: African, Afro-Creoles, and the Realities of Bondage in the Kingdom of Quito, 1600-1800. PhD dissertation, The Ohio State University at Columbus.

Burns, R. 2000. Las siete partidas, Vol. 5: Underworlds. Philadelphia PA: University of Pennsylvania Press.

Bybee, J. 1985. Morphology: A Study of the Relation between Meaning and Form [Typological Studies in Language 9]. Amsterdam: John Benjamins. DOI: 10.1075/tsl.9

Camacho, J. 2013. Null subjects. Cambridge: CUP. DOI: 10.1017/CBO9781139524407

Canfield, L. 1981. Spanish Pronunciation in the Americas. Chicago IL: University of Chicago Press.

Carroll, P. 1991. Blacks in Colonial Veracruz. Austin TX: University of Texas Press.

Centurión Vallejo, H. 1954. Esclavitud y manumisión de negros en Trujillo. Trujillo: Imprenta de la Universidad de Trujillo.

Chaudenson, R. 1979. Les creoles francais. Evreux: Nathan.

Chaudenson, R. 1992. Des iles, des homes, des langues. Paris: L'Harmattan. 
Chaudenson, R. 2001. Creolization of Language and Culture. London: Routledge. DOI: $10.4324 / 9780203440292$

Chomsky, N. 1981. Lectures on Government and Binding. Dordrecht: Foris.

Chomsky, N. 1982. Some Concepts and Consequences of the Theory of Government and Binding. Cambridge MA: The MIT Press.

Chomsky, N. 1995. The Minimalist Program. Cambridge MA: The MIT Press.

Chomsky, N. 2000. Minimalist inquiries: The framework. In Step by step: Essays on Minimalist Syntax in Honor of Howard Lasnik, R. Martin, D. Michaels \& J. Uriagereka (eds), Cambridge MA: The MIT Press.

Chomsky, N. 2001. Derivation by phase. In Ken Hale: A Life in Linguistics, M. Kenstowicz (ed.), 1- 52. Cambridge MA: The MIT Press.

CHSJ. 2012. Casa hacienda San José. <www.havciendasanjose.com.pe>

Clements, C. 2009. The Linguistic Legacy of Spanish and Portuguese. Cambridge: CUP. DOI: $10.1017 / \mathrm{CBO} 9780511576171$

Clements, C. \& Koontz-Garboden, A. 2002. Two Indo-Portuguese creoles in contrast. Journal of Pidgin and Creole Languages 17: 191-236. DOI: 10.1075/jpcl.17.2.03cle

Colmenares, G. 1997. Historia económica y social de Colombia: Popayán una sociedad esclavista 1680-1800. Cali: TM Editores.

Cook, A. \& Cook, N. (eds). 1998. Cieza de León, Pedro de. The Discovery and Conquest of Peru: Chronicles of the New World Encounter. Durham NC: Duke University Press.

Cordova Alvarez, Pedro. 1995. El habla del Azuay. Cuenca: Nucleo del Azuay de la Casa de la Cultura Ecuatoriana 'Benjamin Carrion'.

Coronel Feijóo, R. 1991. El valle sangriento de los indígenas de la coca y el algodón a la hacienda cañera jesuita, 1580-1700. Quito: ABYA-YALA.

Correa, J.A. 2012. La entonación del palenquero y del Kateyano hablado en Palenque (Colombia). Bogotá: Instituto Caro y Cuervo

Crespo, A. 1995. Esclavos negros en Bolivia. La Paz, Bolivia: Librería Editorial Juventud.

Cuba, M. 2002. El castellano hablado en Chincha. Lima: Talleres Gráficos de Angélica Tapia M.

Curtin, P. 1969. The Atlantic Slave Trade: A Census. Madison WI: University of Wisconsin Press.

Cushner, N. 1980. Lords of the Land: Sugar, Wine, and the Jesuit Estates of Coastal Peru. Albany NY: State University of New York Press.

Delafosse, M. 1931. Afrique occidentale francaise. In Historie des colonies francaises et de l'expansion de la France dans le monde, T. IV, G. Honotaux \& A. Martineau (eds), 1-365. Paris: Société de l'Historie/Librarie Plon.

Delicado-Cantero M. \& Sessarego, S. 2011. Variation and syntax in number expression in AfroBolivian Spanish. In Proceedings of the 13th Hispanic Linguistic Symposium, L. Ortiz-López (ed.), 42-53. Somerville MA: Cascadilla Press.

Díaz-Campos, M. \& Clements, C. 2005. Mainland Spanish colonies and Creole genesis: The Afro-Venezuelan area revisited. In Proceedings of the Second Workshop on Spanish Sociolinguistics, L. Sayahi \& M. Westmoreland (eds), 41-53. Somerville MA: Cascadilla Press.

Díaz-Campos, M. \& Clements, C. 2008. A Creole origin for Barlovento Spanish? A linguistic and socio-historical inquiry. Language in Society 37: 351-383.

DOI: $10.1017 /$ S0047404508080548

Donaire Vizarreta, J. 1987. Campiña iqueña: aspectos folklóricos. Lima: Gráficos de Italperú.

Elkins, S. 1959. Slavery: A Problem in American Institutional and Intellectual Life. Chicago IL: University of Chicago Press. 
Escobar, A.M. 1988. Hacia una tipologia del bilinguismo en el Perú. Lima: IEP.

Finely, M. 1980. Ancient Slavery and Modern Ideology. London: Chatto and Windus.

Flores Galindo, A. 1984. Aristocracia y plebe: Lima 1760-1830 (Estructura de clases y sociedad colonial). Lima: Mosca Azul.

Flores Guzmán, R. 2003. Asientos, compañías, rutas, mercados y clientes: Estructura del tráfico de esclavos a fines de la época colonial (1770-1801). In Etnicidad y discriminación racial en la historia del Perú. Vol II, A.C. Carrillo (ed.), 11-42. Lima: Pontificia Universidad Católica del Perú.

Franceschina, F. 2002. Case and phi-feature agreement in advanced L2 Spanish grammars. In EUROSLA Yearbook, Vol. 2, S.H. Foster-Cohen, T. Ruthenberg \& M.L. Poschen (eds), 7186. Amsterdam: John Benjamins. DOI: 10.1075/eurosla.2.07fra

Franceschina, F. 2005. Fossilized Second Language Grammars [Language Acquisition and Language Disorders 38]. Amsterdam: John Benjamins. DOI: 10.1075/lald.38

Gálvez Ronceros, A. 1975. Monólogo desde las tinieblas. Lima: Inti Editores.

García Mayo, M. \& Hawkins, R. 2009. The Second Language Acquisition of Articles [Language Acquisition and Language Disorders 49]. Amsterdam: John Benjamins.

DOI: $10.1075 /$ lald.49

Genovese, E. 1967. The Political Economy of Slavery: Studies in Economy and Society of the Slave South. New York NY: Vintage Books.

Goodman, M. 1987. The Portuguese element in the American Creoles. In Pidgin and Creole Languages: Essays in Memory of John E. Reinecke, G. Gilbert (ed.), 361-405. Honolulu HI: University Press of Hawaii.

Granda De, G. 1968. La tipología criolla de dos hablas del área lingüística hispanica. Thesaurus 23: 193-205.

Granda De, G. 1970. Un temprano testimonio sobre las hablas 'criollas' en África y América. Thesaurus, XXV(1): 1-11.

Granda De, G. 1971. Algunos datos sobre la pervivencia del 'criollo' en Cuba. Boletín de la Real Academia Española 51: 481-491.

Granda De, G. 1978. Estudios lingüísticos afrohispánicos y criollos. Madrid: Gredos.

Grimshaw, J. \& Samek-Lodovici, V. 1998. Optimal subjects and subject universals. In Is the Best Good Enough? Optimality and Competition in Syntax, P. Barbosa, D. Fox, P. Hagstrom, M. McGinnis \& D. Pesetsky (eds), 193-219. Cambridge MA: The MIT Press.

Guirao, R. 1938. Obrita de la poesía afrocuban 1928-1937. Havana: Ucar García.

Guman Poma de Ayala, F. 1615[1987]. Nueva crónica y buen gobierno, J. Murra, R. Adorno \& J. Urioste (eds). Mexico DF: Siglo XXI.

Gutiérrez-Bravo, R. 2005. Structural Markedness and Syntactic Structure. New York NY: Routledge.

Gutiérrez-Bravo, R. 2007. Prominence scales and unmarked word order in Spanish. Natural Language and Linguistic Theory 25: 235-271. DOI: 10.1007/s11049-006-9012-7

Gutiérrez-Bravo, R. 2008. Topicalization and preverbal subjects in Spanish $w h$-interrogatives. In Selected Proceedings of the 10th Hispanic Linguistics Symposium, J. Bruhn de Garavito \& E. Valenzuela (eds), 225-236. Somerville MA: Cascadilla Proceedings Project.

Gutiérrez-Rexach, J. \& Sessarego, S. 2011. On the nature of bare nouns in Afro-Bolivian Spanish. In Romance Linguistics 2010 [Current Issues in Linguistic Theory 318], J. Herschensohn (ed.), 191-204. Amsterdam: John Benjamins. DOI: 10.1075/cilt.318.12gut

Gutiérrez-Rexach, J. \& Sessarego, S. 2014. Morphosyntactic variation and gender agreement in three Afro-Andean dialects. Lingua 151: 142-161. DOI: 10.1016/j.lingua.2014.04.011 
Guy, G. 1981. Linguistic Variation in Brazilian Portuguese: Aspects of the Phonology, Syntax, and Language History. PhD dissertation, University of Pennsylvania.

Guy, G. 2004. Muitas linguas: The linguistic impact of Africans in colonial Brazil. In Enslaving Connections: Changing Cultures of Africa and Brazil During the Era of Slavery, J.C. Curto \& P.E. Lovejoy (eds), 125- 137. New York NY: Humanity Books.

Harth-Terré, E. \& Márquez Abanto, A. 1961. El artesano negro en la arquitetura virreinal limeña. Revista del Archivo Nacional del Perú 25: 360-430.

Hawkins, R. 1998. The inaccessibility of formal features of functional categories in second language acquisition. Paper presented at the Pacific Second Language Research Forum, Tokyo, March 1998.

Helps, A. 1900. The Spanish Conquest in America and its Relation to the History of Slavery and to the Government of Colonies, 1855-1861, 4 Vols. London: John Lane.

Herschensohn, J. 2000. The Second Time Around: Minimalism and L2 Acquisition [Language Acquisition and Language Disorders 21]. Amsterdam: John Benjamins.

DOI: $10.1075 /$ lald.21

Hespanha, A.M. 2003. Introduzione alla storia del diritto europeo. Bologna: Il Mulino.

Holm, J. 1992. Popular Brazilian Portuguese: A semi-creole. In Actas do colóquio sobre crioulos de base lexical portuguesa, E. d'Andrade \& A. Kihm (eds), 37- 66. Lisboa: Colibrí.

Holm, J. 2004. Languages in Contact: The Partial Restructuring of Vernaculars. Cambridge: CUP.

Holm, J.A. \& Patrick, P.L. (eds). 2007. Comparative Creole Syntax. Parallel Outlines of 18 Creole Grammars. London: Battlebridge.

Hualde, J.I. \& Schwegler, A. 2008. Intonation in Palenquero. Journal of Pidgin and Creole Languages 23: 1-31. DOI: 10.1075/jpcl.23.1.02hua

Jacobs, B. 2012. Origins of a Creole: The History of Papiamentu and its African ties. Berlin: De Gruyter. DOI: 10.1515/9781614511076

Jacobsen, N. 1974. The development of Peru's slave population and its significance for coastal agriculture, 1792-1854. Ms.

Johnson, J. \& Newport, E.N. 1989. Critical period effects in second language learning: The influence of maturational state on acquisition of English as a second language. Cognitive Psychology 21: 60-99. DOI: 10.1016/0010-0285(89)90003-0

Jouve Martín, J. 2003. Esclavos negros, escribas blancos: Escritura, esclavitud y colonialismo en Lima (1650-1700). Washington DC: Georgetown University.

Keith, R. 1976. Conquest and agrarian change. The emergence of the hacienda system on the Peruvian coast. Cambridge MA: Harvard University Press.

Kempen, G. \& Hoenkamp, E. 1987. An incremental procedural grammar for sentence formulation. Cognitive Science 11: 201-258. DOI: 10.1207/s15516709cog1102_5

King, L. \& Suñer, M. 2007. Gramática española: Análisis y práctica. New York NY: McGraw-Hill. Kiple, K. 1976. Blacks in Colonial Cuba, 1774-1899. Gainesville FL: University of Florida.

Klee, C.A. \& Lynch, A. 2009. El español en contacto con otras lenguas. Washington DC: Georgetown University Press.

Kouwenberg, S. \& Patrick, P.L. 2003. Reconsidering the role of second language acquisition in pidginization and creolization. Studies in Second Language Acquisition 25(2): 175-306. Special issue. DOI: 10.1017/S0272263103000081

Kouwenberg, S. 2006. L1 transfer and the cut-off point for L2 acquisition processes in Creole formation. In Lefevbre, White \& Jourdan (eds), 205-219.

Konetzke, R. 1953. Colección de documentos para la historia de la formación social de Hispanoamérica, 1493-1810. Madrid: Consejo Superior de Investigaciones Científicas. 
Kuhn, T. 1970 [1962]. The Structure of Scientific Revolutions. Chicago IL: The University of Chicago Press.

Lasnik, H. 2001a. A note on the EPP. Linguistic Inquiry 32: 356-362.

DOI: 10.1162/ling.2001.32.2.356

Lasnik, H. 2001b. Subjects, objects, and the EPP. In Objects and Other Subjects: Grammatical Functions, Functional Categories, and Configurationality, W. Davies \& S. Dubinsky (eds), 103-121. Dordrecht: Kluwer.

Laurence, K. 1974. Is Caribbean Spanish a case of decreolization? Orbis 23: 484-499.

Lavellé, B. 1999. Amor y oppression en los Andes colonials. Lima: IPE.

Lefebvre, C. 1998. Creole Genesis and the Acquisition of Grammar. Cambridge: CUP.

Lefevbre, C., White, L. \& Jourdan, C. (eds). 2006. L2 Acquisition and Greole Genesis: Dialogues [Language Acquisition and Language Disorders 42]. Amsterdam: John Benjamins.

DOI: $10.1075 /$ lald. 42

Leonini, C. 2006. The Acquisition of Object Clitics and Definite Articles: Evidence from Italian as $\mathrm{L} 2$ and L1. PhD dissertation, Università degli Studi di Firenze.

Levelt, W. 1989. Speaking. From Intention to Articulation. Cambridge MA: The MIT Press.

Lipski, J. 1987. The Chota Valley: Afro-Hispanic language in highland Ecuador. Latin American Research Review 22: 155-170.

Lipski, J. 1989. The Speech of the Negros Congos of Panama [Creole Language Library 4]. Amsterdam: John Benjamins. DOI: 10.1075/cll.4

Lipski, J. 1993. On the non-creole basis for Afro-Caribbean Spanish. Albuquerque NM: University of New Mexico Press. <http://www.personal.psu.edu/jml34/noncreol.pdf>

Lipski, J. 1994a. El lenguaje afroperuano: Eslabón entre Africa y América. Anuario de Lingüística Hispánica 10: 179-216.

Lipski, J. 1994b. Latin American Spanish. New York NY: Longman.

Lipski, J. 1998. El español bozal. In Perl \& Schwegler (eds), 293-227.

Lipski, J. 2000. Spanish-based creoles in the Caribbean. <http://www.personal.psu.edu/jml34/ spcreole.pdf>

Lipski, J. 2005. A History of Afro-Hispanic Language: Five Centuries and Five Continents. Cambridge: CUP. DOI: 10.1017/CBO9780511627811

Lipski, J. 2006. Afro-Bolivian Spanish and Helvetia Portuguese: Semi-creole parallels. Papia 16: 96-116.

Lipski, J. 2007a. El lenguaje afromexicano en el contexto de la lingüística afrohispánica. Publications of the Afro-Latin American Research Association (PALARA) 11: 33-45.

Lipski, J. 2007b. Castille and the hydra: The diversification of Spanish in Latin America. <http:// www.personal.psu.edu/jml34/papers.htm>

Lipski, J. 2008. Afro-Bolivian Spanish. Frankfurt/Madrid: Vervuert/Iberoamericana.

Lipski, J. 2009. Afro-Choteño speech: Towards the (re)creation of "Black Spanish. Negritud 2: 99-120.

Lipski, J. 2010. Depleted plural marking in two Afro-Hispanic dialects: Separating inheritance from innovation. Language Variation and Change 22: 1-44.

DOI: $10.1017 /$ S0954394510000025

Lockhart, J. 1968. Spanish Peru, 1532-1560: A Social History. Madison WI: University of Wisconsin Press.

Lorenzino, G. 1998. El español caribeño: Antecedentes sociohistóricos y lingüísticos. In Perl \& Schwegler (eds), 26-39.

Lucchesi, D., Baxter, A. \& Riberio, I. (eds). 2009. O português afro-brasileiro. Salvador: EDUFBA. 
Lucena Salmoral, M. 1994. Sangre sobre piel negra. Quito: Abya-Yala.

Lucena Salmoral, M. 1999. Los Códigos Negros de la América Española. Alcalá de Henares: Universidad de Alcalá.

Lucena Salmoral, M. 2000a. Leyes para esclavos: El ordenamiento jurídico sobre la condición, tratamiento, defensa y represión de los esclavos en la América española. Madrid: Digibis.

Lucena Salmoral, M. 2000b. Relatos de viajeros europeos en Iberoamérica, s. XV-XX. Madrid: Digibis.

Lucena Salmoral, M. 2002. La esclavitud en la América española. Centro de Estudios Latinoamericanos. Warsow: Uniwersytet Warszawski.

Lucena Salmoral, M. 2005. Regulación de la esclavitud negra en las colonias de América Española (1503-1886): Documentos para su estudio. Alcalá de Henares: Universidad de Alcalá.

Macera, P. 1966. Instrucciones para el Manejo de las Haciendas Jesuítas del Perú, ss. XVII-XVIII. Lima: Universidad Nacional Mayor de San Marcos.

Mac-Lean y Estenos, R. 1947. Negros en el nuevo mundo. Lima: PTCM.

Marrone, M. 2001. Lineamento di diritto privato romano. Torino: Giappichelli Editore.

Martohardjono, G. \& Gair, J.W. 1993. Apparent UG inaccessibility in SLA: Misapplied principles or principled misapplications? In Confluence: Linguistics, Second Language Acquisition and Speech Pathology [Language Acquisition and Language Disorders 4], F.R. Eckman (ed.), 79-103. Amsterdam: John Benjamins. DOI: 10.1075/lald.4.08mar

Masó, C. 1976. Historia de Cuba. Miami: Ediciones Universal.

Mayén, N. 2007. Afro-Hispanic Linguistic Remnants in Mexico: The Case of the Costa Chica Region of Oaxaca. PhD dissertation, Purdue University.

McWhorter, J. 1997. Towards a New Model of Creole Genesis. Bern: Peter Lang.

McWhorter, J. 2000. The Missing Spanish Creoles. Recovering the Birth of Plantation Contact Languages. Berkley CA: University of California Press.

Megenney, W. 1984. El habla bozal cubana ¿lenguaje criollo o adquisición imperfecta? La Torre 33(123): 109-139. (Universidad de Puerto Rico)

Megenney, W. 1985. La influencia criollo-portuguesa en el español caribeño. Anuario de Lingüística Hispánica 1: 157-180.

Megenney, W. 1993. Elementos criollo-portugueses en el español dominicano. Montalbán 15: $3-56$.

Megenney, W. 1999. Aspectos del lenguaje afronegroide en Venezuela. Frankfurt/Madrid: Vervuert/Iberoamericana.

Meiklejohn, N. 1981. The implementation of slave legislation in eighteenth-century New Granada. In Slavery and Race Relations in Latin America, R. Tolpin (ed.). Westport CT: Greenwood Press.

Mellafe, R. 1959. La introducción de la esclavitud negra en Chile, tráfico y rutas. Santiagó: Universidad de Chile.

Migge, B. 2003. Creole Formation as Language Contact: The Case of the Suriname Creoles [Creole Language Library 25]. Amsterdam: John Benjamins. DOI: 10.1075/cll.25

Mintz, S. 1971. The socio-historical background to pidginization and creolization. In Pidginization and Creolization of Languages, D. Hymes (ed.), 481-498. Cambridge: CUP.

Montrul, S. Prince, R. \& Thomé-Williams, A. 2009. Subject expression in the non-native acquisition of Brazilian Portuguese. In Minimalist Inquiries into Child and Adult Language Acquisition: Case Studies across Portuguese, A. Pires \& J. Rothman (eds), 301-325. Berlin: Mouton de Gruyter. DOI: 10.1515/9783110215359.2.301 
Mufwene, S. 1996. The Founder Principle in creole genesis. Diachronica 13: 83-134. DOI: 10.1075/dia.13.1.05muf

Mufwene, S. 2001. The Ecology of Language Evolution. Cambridge: CUP. DOI: $10.1017 / \mathrm{CBO} 9780511612862$

Naro, A. \& Scherre, M.M. 2000. Variable concord in Portuguese: The situation in Brazil and Portugal. In Language Change and Language Contact in Pidgins and Creoles [Creole Language Library 21] John McWhorter (ed.), 235-255. Amsterdam: John Benjamins. DOI: $10.1075 /$ cll.21.09nar

Naro, A. \& Scherre, M.M. 2007. Origens do português brasileiro. São Paulo: Parábola.

Navarrete, M.C. 2005. Génesis y desarrollo de la esclavitud en Colombia siglos XVI y XVII. Cali: Universidad del Valle.

Núñez Ponte, J. 1911. Estudio histórico acerca de la esclavitud y de su abolición en Venezuela. Caracas: Tip. Emp. El Cojo.

Ortiz, F. 1916. Hampa afro-cubana: Los negros esclavos. Estudio sociológico y derecho público. La Habana: Revista Bimestre Cubana.

Ortiz-López, L. 1996. Huellas etno-sociolingüísticas bozales y afrocubanas. Frankfurt/Madrid: Vervuert/Iberoamericana.

Otheguy, R. 1973. The Spanish Caribbean: A creole perspective. In New Ways of Analyzing Variation in English, C.-J. Bailey \& R. Shuy (eds), 323-339. Washington DC: Georgetown University Press.

Peñaherrera de Costales, P. \& Costales Samaniego, A. 1959. Coangue, historia cultural y social de los negros del Chota y Salinas. Quito: DNA.

Pereda Valdés, I. 1965. El negro en el Uruguay, pasado y presente. Montevideo: Instituto Histórico y Geográfico del Uruguay.

Pérez-Inofuentes, D. 2015. Traces of Portuguese in Afro-Yungueño Spanish? Journal of Pidgin and Creole Languages 30: 2, 308-344.

Periodismo en el Perú. 2012. Los pregoneros y campanas en el Perú colonial. <http://periodismoperu1.blogspot.com/2012/04/los-pregoneros-y-campanas-en-el-peru.html>

Perl, M. 1982. Creole morphosyntax in the Cuban 'habla bozal'. Studii şi Cercetări Lingvistice 5: 424-433.

Perl, M. 1985. El fenómeno de la descriollización del 'habla bozal' y el lenguaje coloquial de la variante cubana del español. Anuario de Lingüística Hispánica 1: 191-202.

Perl, M. 1998. Introduction. In Perl \& Schwegler (eds), 1-24.

Perl, M. \& Schwegler, A. (eds). 1998. América negra: Panorámica actual de los estudios lingüísticos sobre variedades hispanas, portuguesas y criollas. Frankfurt/Madrid: Vervuert/ Iberoamericana.

Phinney, M. 1987. The pro-drop parameter in second language acquisition. In Parameter Setting, Thomas Roeper \& Edwin Williams (eds), 221-238. Dordrecht: Reidel.

DOI: 10.1007/978-94-009-3727-7_10

Pienemann, M. 1998. Language Processing and Second Language Development: Processability Theory [Studies in Bilingualism 15]. Amsterdam: John Benjamins. DOI: 10.1075/sibil.15

Pienemann, M. (ed.). 2005. Cross-linguistic Aspects of Processability Theory [Studies in Bilingualism 30]. Amsterdam: John Benjamins. DOI: 10.1075/sibil.30

Pinharanda Nunes, M. 2013. Traces of superstrate verb inflection in Makista and other Asian-Portuguese creoles. In Ibero-Asian Creoles: Comparative Perspectives [Creole Language Library 46], H. Cardoso, A. Baxter \& M. Pinharanda Nunes (eds), 289-326. Amsterdam: John Benjamins. DOI: 10.1075/cll.46.11pin 
Pires, A. \& Rothman, J. 2009. Introduction. In Minimalist Inquiries into Child and Adult Language Acquisition. Case Studies Across Portuguese, A. Pires \& J. Rothman (eds), 5-34. Berlin: Mouton de Gruyter. DOI: 10.1515/9783110215359.0.5

Pires, A. \& Thomason, S.G. 2008. How much syntactic reconstruction is possible? In Principle of Syntactic Reconstruction [Current Issues in Linguistic Theory 302], Gisella Ferraresi \& Maria Goldbach (eds), 27-72. Amsterdam: John Benjamins. DOI: 10.1075/cilt.302.04pir

Plag, I. 2008a. Creoles as interlanguages: Inflectional morphology. Journal of Pidgin and Creole Languages 23(1): 109-130.

Plag, I. 2008b. Creoles as interlanguages: Syntactic structures. Journal of Pidgin and Creole Languages 23(2): 307-328. DOI: 10.1075/jpcl.23.2.06pla

Plag, I. 2009a. Creoles as interlanguages: Phonology. Journal of Pidgin and Creole Languages 24(1): 119-138. DOI: $10.1075 /$ jpcl.24.1.06pla

Plag, I. 2009b. Creoles as interlanguages: Word-fromation. Journal of Pidgin and Creole Languages 24(2): 339-362. DOI: 10.1075/jpcl.24.2.05pla

Porter, R. 1989. European Activity on the Goald Coast, 1620-1667. PhD dissertation, University of South Africa, Pretoria.

Pound, R. 1910. Law in Books and Law in Action. 44 American Law Review 12.

Restall, M. 2000. Black conquistadors: Armed Africans in early Spanish America. The Americas 57(2): 171-205. DOI: 10.1353/tam.2000.0015

Romero, F. 1987. El negro en el Perú y su transculturación lingüística. Lima: Editorial Milla Btres.

Romero, F. 1988. Quimba, fa, malambó, ñeque: Afronegrismos en el Perú. Lima: IEP.

Romero, F. 1994. Safari africano y compraventa de esclavos para el Perú (1412-1818). Lima: IEP.

Ruiz-García, M. 2009. El español popular del Chocó, Colombia. Saarbrücken: VDM Verlag Dr. Müller.

Sagarra, N. \& Herschensohn, J. 2008. Processing gender in L2 Spanish. In Proceedings of the 32nd Annual Boston University Conference on Language Development, H. Chan, H. Jacob \& E. Kapia (eds), 427-437. Somerville MA: Cascadilla Press.

Sagarra, N. \& Herschensohn, J. 2011. Asymmetries in gender and number agreement processing in late bilinguals. In Selected Proceedings of the 13th Hispanic Linguistics Symposium, Luis A. Ortiz-López (ed.), 169-177. Somerville MA: Cascadilla Press.

Sala i Vila, N. 1989. Revueltas indigenas en el Peru tardo colonial. PhD dissertation, Universidad de Barcelona.

Sales, N. 1974. Sobre esclavos, reclutas y mercaderes de quintos. Barcelona: Ariel.

Sánchez L. \& Giménez, M.J. 1998. The L2 Acquisition of definite determiners: From null to overt. In Proceedings of the 22nd Annual Boston University Conference on Language Development, A. Greenhill, M. Hughes, H. Littlefield \& H. Walsh (eds), 640-650. Somerville MA: Cascadilla Press.

de Sandoval, A. 1627[1956]. De instauranda aethiopum salute. El mundo de la esclavitud negra en América. Bogotá: Biblioteca de la Presidencia de Colombia.

Sater, W. 1974. The black experience in Chile. In Slavery and Race Relations in Latin America, R. Toplin (ed.), 13-50. Westport CT: Greenwood Press.

Schuchardt, H. 1889. Beiträge zur Kenntnis des Kreolischen Romanisch IV. Zum Negerportugiesischen der Ilha do Príncipe. Zeitschrift für Romanische Philologie 13: 461-475.

DOI: 10.1515/zrph.1889.13.1-4.463

Schumann, J.H. 1978. The Pidginization Process: A Model for Second Language Acquisition. Rowley MA: Newbury House. 
Schwegler, A. 1993. Rasgos (afro-)portugueses en el criollo del Palenque de San Basilio (Colombia). In Homenaje a José Pérez Vidal, C. Díaz Alayón (ed.), 667-696. La Laguna, Tenerife: Litografia A. Romero S. A.

Schwegler, A. 1996a. "Chi ma nkongo": Lengua y rito ancestrales en El Palenque de San Basilio (Colombia). Frankfurt/Madrid: Vervuert/Iberoamericana.

Schwegler, A. 1996b. La doble negación dominicana y la génesis del español caribeño. Hispanic Linguistics 8: 247-315.

Schwegler, A. 1999. Monogenesis revisited: The Spanish perspective. In Creole Genesis, Attitudes and Discourse [Creole Language Library 20], J. Rickford \& S. Romaine, 235-262. Amsterdam: John Benjamins. DOI: 10.1075/cll.20.16sch

Schwegler, A. 2002. Review of The Missing Spanish Creoles: Recovering the Birth of Plantation Contact Languages by John McWhorter. Language in Society 31: 113-121.

DOI: $10.1017 /$ S0047404502211057

Schwegler, A. \& Morton, T. 2003. Vernacular Spanish in a microcosm: Kateyano in El Palenque de San Basilio (Colombia). Revista Internacional de Lingüística Iberoamericana (RILI) 1: 97-159.

Schwegler, A. 2010. State of the discipline. Pidgin and creole studies: Their interface with Hispanic and Lusophone linguistics. Studies in Hispanic and Lusophone Linguistics 3(2): 431484. DOI: $10.1515 /$ shll-2010-1082

Schwegler, A. 2014. Portuguese remnants in the Afro-Hispanic diaspora. In Portuguese-Spanish Interfaces: Diachrony, Synchrony, and Contact [Issues in Hispanic and Lusophone Languages 1], P. Amaral \& A.M. Carvalho (eds), 403-441. Amsterdam: John Benjamins.

DOI: $10.1075 /$ ihll.1.21sch

Schwegler, A. Forthcoming. Combining population genetics (DNA) with historical linguistics: On the African origins of Latin America's black and mulatto populations Spanish and Portuguese Parallels: Impoverished number agreement as a vernacular feature of two rural dialects. In Spanish Language and Sociolinguistic Analysis, S. Sessarego \& F. Tejedo (eds). Amsterdam: John Benjamins.

Schwenter, S. 2002. Pragmatic variation between negatives: Evidence from Romance. University of Pennsylvania Working Papers in Linguistics 8(3): 249-263.

Schwenter, S. 2005. The pragmatics of negation in Brazilian Portuguese. Lingua 115: 14271456. DOI: 10.1016/j.lingua.2004.06.006

Sessarego, S. \& Gutiérrez-Rexach, J. 2011. A minimalist approach to gender agreement in the Afro-Bolivian DP: Variation and the specification of uninterpretable features. In The Diachronic of Gender Marking, G. De Vogelaer \& M. Janse (eds). Special issue of Folia Linguistica 45(2): 465-488.

Sessarego, S. \& J. Gutiérrez-Rexach. 2012. Variation, universals, and contact-induced change: Language evolution across generations and domains. In Current Formal Aspects of Spanish Syntax and Semantics, M. González-Rivera \& S. Sessarego (eds), 251-270. Newcastle upon Tyne: Cambridge Scholars.

Sessarego, S. \& Ferreira, L. In press. Spanish and Portuguese parallels: Impoverished number agreement as a vernacular feature of two rural dialects. In Spanish Language and Sociolinguistic Analysis, S. Sessarego \& F. Tejedo (eds). Amsterdam: John Benjamins.

Sessarego, S. 2011a. Introducción al idioma afroboliviano: Una conversación con el awicho Manuel Barra. Cochabamba/La Paz: Plural Editores. 
Sessarego, S. 2011b. On the status of Afro-Bolivian Spanish features: Decreolization or vernacular universals? In Proceedings of the Fifth Workshop on Spanish Sociolinguistics, J. Michnowicz \& R. Dodsworth (eds), 125-141. Somerville MA: Cascadilla Press.

Sessarego, S. 2012. Non-creole features in the verb system of Afro-Hispanic languages: New insights from SLA studies. International Journal of Linguistics 4(1): 146-157.

DOI: $10.5296 /$ ijl.v4i1.1415

Sessarego, S. 2013a. Chota Valley Spanish: A second look at creole monogenesis. Revista Internacional de Lingüística Iberoamericana 22(2): 129-148.

Sessarego, S. 2013b. Afro-Hispanic contact varieties as advanced second languages. IBERIA 5(1): 96-122.

Sessarego, S. 2013c. Chota Valley Spanish. Frankfurt/Madrid: Vervuert/Iberoamericana.

Sessarego, S. 2013d. On the non-creole bases for Afro-Bolivian Spanish. Journal of Pidgin and Creole Languages 28(2): 363-407. DOI: 10.1075/jpcl.28.2.04ses

Sessarego, S. 2013e. Enhancing dialogue between quantitative sociolinguistics and minimalist syntax. Studies in Hispanic and Lusophone Linguistics 5(2): 79-97.

Sessarego, S. 2014a. The Afro-Bolivian Spanish Determiner Phrase: A Microparametric Account. Columbus OH: The Ohio State University Press.

Sessarego, S. 2014b. On Chota Valley Spanish origin: Linguistic and socio-historical evidence. Journal of Pidgin and Creole Languages 29(1): 86-133. DOI: 10.1075/jpcl.29.1.03ses

Sessarego, S. 2014c. Afro-Peruvian Spanish in the Context of Spanish Creole Genesis. Spanish in Context 11(3): 381-401. DOI: 10.1075/sic.11.3.04ses

Sessarego, S. In press. A response to Pérez-Inofuentes. Journal of Pidgin and Creole Languages.

Sharp, W.F. 1976. Slavery on the Spanish Frontier: The Colombian Chocó 1680-1810. Norman OK: University of Oklahoma Press.

Siegel, J. 2008. Pidgin/Creoles and second language acquisition. In The Handbook of Pidgin and Creole Studies, S. Kouwenberg \& J. Singler (eds), 189-218. Oxford: Blackwell.

Sorace, A. 2000. Syntactic optionality in non-native grammars. Second Language Research 16: 93-102. DOI: 10.1191/026765800670666032

Sorace, A. 2003. Near-nativeness. In The Handbook of Second Language Acquisition, C. Doughty \& M.H. Long (eds), 130-153. Oxford: Blackwell. DOI: 10.1002/9780470756492.ch6

Sorace, A. 2004. Native language attrition and developmental instability at the syntax-discourse interface: Data, interpretations and methods. Bilingualism: Language and Cognition 7: 143-145. DOI: 10.1017/S1366728904001543

Sotomayor Roggero, C. \& Aranda de Los Ríos, R. 1979. Sublevación de los campesinos negros en Chincha. 1879. Lima: Universidad Nacional Mayor de San Marcos.

Stevenson, W.B. 1828. Voyage en Araucanie, au Chili, au Pérou et dans la Colombie, ou Relation historique et descriptive d'un séjour de vingt ans dans l'Amérique du Sud, suivie d'un précis des révolutions des colonies espagnoles de l’Amérique du Sud. Paris: Librairie universelle de P. Mongie.

Stewart, W. 1962. Creole languages in the Caribbean. In Study of the Role of Second Languages, F.A. Rice (ed.), 34-53. Washington DC: Center for Applied Linguistics.

Studer, E. 1958. La trata de negros en el Río de la Plata durante el siglo XVIII. Buenos Aires: Unversidad de Buenos Aires.

Tagliamonte, S. 2006. Analyzing Sociolinguistic Variation. Cambridge: CUP. DOI: $10.1017 / \mathrm{CBO} 9780511801624$

Tannenbaum, F. 1946. Slave and Citizen. New York NY: Vintage Books.

Távara, S. 1855. Abolición de la esclavitud. Lima: Imprenta del Comercio. 
Taylor, D. 1961. New languages for old in the West Indies. Comparative Studies in Society and History 3: 277-288. DOI: 10.1017/S0010417500012238

Thomason, S. \& Kaufman, T. 1988. Language Contact, Creolization and Genetic Linguistics. Berkeley CA: University of California Press.

Torres Saldamando, E. 1900[1967]. Apuntes Históricos sobre las encomiendas en el Perú. Lima: UNMSM.

de Trazegnies, F. 1981. Ciriaco de Urtecho. Litigante por amor. Lima: Pontificia U iversidad Catolica del Perú.

Valdman, A. 1964. Du créole au français en Haiti. Linguistics 8: 84-94.

DOI: 10.1515/ling.1964.2.8.84

Vázquez de Espinosa, A. 1942. Compendium and Description of the West Indies, transl. C. Upson Clark. Washington DC: Smithsonian Institution.

Veenstra, T. 2008. Creole genesis: The impact of the Language Bioprogram Hypothesis. In The Handbook of Pidgin and Creole Studies, S. Kouwenberg \& J. Singler (eds), 219-241. Oxford: Wiley Blackwell.

Vegas de Cáceres, I. 1999. Una imagen distorsionada: las haciendas de Lima hacia fines del siglo XVIII. In El Perú en el esiglo XVIII. La era borbónica, S. O’Phelan Godoy (ed.). Lima: Instituto Riva Agüero.

Visconti, J. 2009. From 'textual' to 'impersonal': On the diachrony of the Italian particle mica. Journal of Pragmatics 41: 937-950. DOI: 10.1016/j.pragma.2008.08.012

Watson, A. 1989. Slave Law in the Americas. Athens GA: The University of Georgia Press.

West, R. 1957. The Pacific lowlands of Colombia. Baton Rouge LA: Louisiana State University Press.

Wheat, D. 2009. The Afro-Portuguese Maritime World and the Foundations of Spanish Caribbean Society, 1570-1640. PhD dissertation, Vanderbilt University.

Wheat, D. 2011. The first great waves: African provenance zones for the transatlantic slave trade to Cartagena de Indias, 1570-1640. Journal of African History 52: 1-22.

DOI: $10.1017 /$ S0021853711000119

Whinnom, K. 1965. Origin of European-based creoles and pidgins. Orbis 14: 510-527.

White, L. 1985. The pro-drop parameter in adult second language acquisition. Language Learning 35(1): 257-277. DOI: 10.1111/j.1467-1770.1985.tb01014.x

White, L. 1986. Implications of parametric variation for adult second language acquisition: An investigation of the 'pro-drop' parameter. In Experimental Approaches to Second Language Acquisition, Vivian Cook (ed.), 55-72. Oxford: Pergamon.

White, L. 1992. Subjacency violations and empty categories in L2 acquisition. In Island Constraints, H. Goodluck \& M. Rochement (eds), 445-464. Dordrecht: Kluwer.

DOI: 10.1007/978-94-017-1980-3_17

White, L. \& Juffs, A. 1998. Constraints on wh-movement in two different contexts of non-native language acquisition: Competence and processing. In The Generative Study of Second Language Acquisition, S. Flynn, G. Martohardjono \& W. O’Neil (eds), 111-129. Mahwah NJ: Lawrence Erlbaum Associates.

White, L., Valenzuela, E., Kozlowska-Macgregor, M. \& Leung, Y.-K.I. 2004. Gender and number agreement in nonnative Spanish. Applied Psycholinguistics 25: 105-133.

DOI: $10.1017 /$ S0142716404001067

Whitten, N. 1974. Black Frontiersmen. New York NY: Wiley. 
Willis, E.W. 2003. The Intonational System of Dominican Spanish: Findings and Analysis. PhD dissertation, University of Illinois Urbana.

Willis, E.W. \& Bradley, T.G. 2008. Contrast maintenance of taps and trills in Dominican Spanish: Data and analysis. In Selected Proceedings of the 3rd Conference on Laboratory Approaches to Spanish Phonetics and Phonology, L. Colantoni \& J. Steele, 87-100. Somerville MA: Cascadilla Proceedings Project.

Winford, D. 2000. "Intermediate" creoles and degrees of change in creole formation: The case of Bajan. In Degrees of Restructuring in Creole Languages [Creole Language Library 22], I. Neumann-Holzschuh \& E.W. Schneider (eds), 215-146. Amsterdam: John Benjamins. DOI: $10.1075 /$ cll.22.13win 



\section{Index}

Note: page numbers followed by " $n$ " refer to footnotes, by " $\mathrm{t}$ " refer to tables, and by "f" refer to figures. APS refers to Afro-Peruvian Spanish.

\section{A}

$a$ and $d e \quad 53-54$

abolition of slavery $111-112$

accessio $123-124,133$

Act for the Better Ordering of Slaves 127

advanced conventionalized second language

overview $\quad 66-67$

APS as $64,71-77$

cases supporting $\quad 117-120$

contact-induced restructuring and $63-64,64 \mathrm{f}$

creoles as interlanguages 65

Afro-Bolivian Spanish (ABS)

as advanced conventionalized second language 118-119

bare nouns 75

con 54-55

decreolization $9-10$

gender agreement in noun phrases 44

locative function of preposition $a \quad 54$

number agreement in noun phrases 40

paragogic vowels 29

Afrogenesis Hypothesis

about 6, 13-16, 63-64

decreolization compared $\quad 63-64$

Legal Hypothesis of Creole Genesis compared 151-152

shortcomings of $\quad 16-20$

see also McWhorter, J.

Afro-Hispanic dialects 19, 67-70, 68f, 69-7ot see also specific dialects

Afro-Hispanic linguistic remnants in Mexico (Mayén) 19

Afro-Mexican Spanish 18, 29

Afro-Peruvian Spanish (APS)

about 1, 2f

as advanced conventionalized second language 64

Afrogenesis Hypothesis and $19-20,160$ article systems $\quad 74-75$

as disappearing 3,61

lexical items $59-61$

multidisciplinary perspective needed for study of 1

see also advanced conventionalized second

language; grammatical features of APS;

Legal Hypothesis of Creole Genesis; status of Afro-Peruvian Spanish

Afro-Portuguese 21, 77-78n13

Afro-Veracrucian Spanish $\quad 18-19$

Agree operation $\quad 72-73$

Aguirre, Carlos 79, 99-100, 102, 108, 110

Aguirre Beltrán, G. 18

Alleyne, M. 64

almorjarifazgos (import taxes) 82

Amaru, Túpac 111

Amazonian lowlands zone 25-26

Andean highlands zone 24

Anderson, R. 65

Andrés-Gallego, J. 100, 133-134, 136, 137-138, 143

Aramburu, Julián de 100

Aranda de Los Ríos, R. $\quad 114$

Argentina 136

arrebiatado 59

Artaza, Juana María 143

article systems $\quad 74-75$

asientos $81,82,99$

atajo de negritos 59

Azara, Felix de 136

azumagar 59

B

Barbados 151

bare nouns 47-48, 69t, 74-75

Barlovento, Venezuala $\quad 8-9,117$

Barrueta, Domingo 100, 147

batán 59 
blacks

lawyers for $100,123 n 38,124,137,143-144$

in medicine 100

ratio of freemen to slaves $11,12 \mathrm{n} 6,82,93,101$, 153

see also slaves and slavery

Bolivia $\quad 117-118$

Bonifacio (slave) 142

Bowser, F. $\quad 85-86,91,95,139$

bozal Spanish $816 \mathrm{n} 2$

bozal Spanish 8,11

bozales 10, 8on14, 154t, 816n2

Bruhn de Garavito, J. 73

bruja 59

Bryant, S. 142

C

cajon 59

Caribs 81

El Carmen hacienda 114, $115 \mathrm{f}$

Carrillo Albornoz y Salazar, Fernando 115

Carrillo de Alboroz, Fernando de 115

Castilla, Ramón 112

catacumbas 59

Catholic Church 103-110, 106-107t, 109f, 113-114, 125

cau cau de mondongo 59

Centurión Vallejo, H. 98

chacras de esclavos (slave fields) 102-103, 105

chandú 59

Charles V 81

chauca 59

Chaudenson, R. $\quad 11,14$

chicote 59

Chilean Indians 81

chivato 59

Chocó, Colombia $\quad 18,152-156,154 \mathrm{t}$

Chomsky, Noam 72

Chota Valley Spanish (CVS)

as advanced conventionalized second language 118-119

Afrogenesis Hypothesis and 17

con $54-55$

decreolization 8

gender agreement in noun phrases 44

locative function of preposition $a \quad 54$

McWhorter on $17,18 \mathrm{n} 7$

number agreement in noun phrases 40

paragogic vowels 29

citizenship 121-122, 123n38

CJC see Corpus Juris Civilis (CJC)
Claudio (slave) 142

Clements, C. $11,17,117,147$

coartación 11, 101, 125

Coastal Haciendas' Internal Regulation

(Reglamiento Interior de las Haciendas de la

Costa) 111-112

Code noir 129-131

Company of Jesus $\quad$ 103-110, 106-107t, 109f,

$113-114,139,144$

con 54-55

condesa 60

consonants

/Cr/ onset consonant clusters 35

conversion $/ \mathrm{f} />\left[\mathrm{h}^{w}\right]$ and pronunciation of $\langle\mathrm{h}>$ 36

loss of word-final /s/ 31-32

neutralization of $/ \mathrm{r} /$ and $/ \mathrm{d} /$ in syllable-initial position $\quad 32-33$

neutralization of $/ \mathrm{f} /$ and $/ \mathrm{l} / \mathrm{33-34}$

neutralization of $/ \mathrm{f} /$ and $/ \mathrm{r} / \quad 34-35$

velarization of $/ \mathrm{n} / \quad 38$

weakening and deletion of /b/, /d/, /g/ 38-39

weakening of syllable-final /s/ 30-31

yeísmo and /j/ weakening $\quad 36-37$

Constantine 122

contact-induced restructuring $\quad 63-64,64 f$

Coronel Feijóo, R. 17

Corpus Juris Civilis (CJC)

creation of 123

Spanish adoption of 120

see also Legal Hypothesis of Creole Genesis

Costales Samaniego, A. 17

creoles

Afro-Hispanic features and $\quad 69-70$

Chincha and 113

as interlanguages 65

ladinos and 102

life cycle of $15,64,78$

slavery history and 10-11, 97-98, 97n24, 108, 110, 160

see also Decreolization Hypothesis; Legal

Hypothesis of Creole Genesis; Spanish creole debate

Crespo, A. 134-135

criers (pregoneros) 90, 9of

criollos 101, 150-151, 153, 154t

Cuba 12, 147-150

Cuba, M.

/Cr/ onset consonant clusters 35

Afrogenesis Hypothesis and 21

Afro-Hispanic features 69 
basis for analysis 23, 26

loss of word-final $/ \mathrm{s} / \quad 31$

neutralization of / $/$ and /d/ in syllable-initial

position 32

number agreement in noun phrases $\quad 41-42$

pleonastic prepositions $d e$ and $a \quad 53$

ser and estar 50

subject-verb agreement 57

subject-verb inversion in questions $58-59$

velarization of $/ \mathrm{n} / \quad 38$

verb phrases 49

weakening and deletion of /b/, /d/, /g/ 39

weakening of syllable-final /s/ 30

Cuban 'habla bozal' 8

Cuban Spanish 11

cuculemu 60

cuculí 60

Cushner, N. 101, 105-106

customary law (pays de droit coutumier) $\quad 129$

cututeo 60

D

danta 60

data collection 3

$d e$ and $a \quad 53-54$

DE INSTAURANDA AETHIOPUM SALUTE

(Sandoval) 6-7

Decreolization Hypothesis 6-10, 63-64, 65-66, $78,159-160$

see also Legal Hypothesis of Creole Genesis

demographics

criollos 101

economic factors in creoles and 5-6, 11-13, 15

Jesuit plantations $\quad 106-107 \mathrm{t}, 106-109$

slaves and slavery $\quad 85-86,88 \mathrm{t}, 91-93,92 \mathrm{t}$, 95-96, 112

demonstratives/definite articles $\quad 43-47,44 t, 45 f$

Díaz-Campos, M. 17, 117

diphthong reduction 27

Donaire Vizarreta, J. 32

double negation $\quad 77-78 \mathrm{n} 13$

Dutch Antilles 121

Dutch slave law 131-132

Dutch West India Company 131

E

economic and demographic factors in creoles

$$
5-6,11-13,15
$$

education $104-105,128$

Eguren de Cillóniz, Manuela 115

El Carmen hacienda $114,115 f$
El Guayabo hacienda $\quad 115 \mathrm{f}$

ele 8, 118-119

English Antilles 10-11

English colonies, slave law in $\quad 126-128$

English pidgin 15

English slave law $126-128,137-138$

English South Sea Company 81

esclavitud a jornal 99-100

Esclavos negros en Bolivia (Crespo) 134-135

estar and ser 50-51

Estudio histórico acerca de la esclavitud y de su abolición en Venezuela (Núñez Ponte) 137

Extended Projection Principle (EPP) 76-77, $76 \mathrm{n} 12$

$\mathrm{F}$

Feijóo, R. 17

Flores Galindo, A. 98-99, 102, 114

forasteros 95, 95n 23

Founder Principle 150

France 129-131, 129n40, 13on41, 137-138

Franceschina, F. 73

Fregenal, Juan de $\quad 91,146$

French Antilles, 10-11

French pidgin 15

French Royal Guinea Company 81

fronted wh-operators (wh-op) $\quad 75-77$

G

Gálvez Roncero, A. 26, 32, 68

García, Juan $83-85,84 \mathrm{t}$

gender agreement in noun phrases $42-47,44 \mathrm{t}$, 45f, 69-7ot, 73-74

grammatical features of APS

overview 23, 26

intonation patterns $39-40,40 f$

morpho-syntactic phenomena $67-70,70 t$

phrase-level constructions $\quad 55-59$

prepositional phrases $53-55$

varieties of Peruvian Spanish $\quad 23-26$

verb phrases $\quad 48-52$

vowels $26-29$

see also consonants; noun phrases; status of Afro-Peruvian Spanish

Granda, Germán de 6-7

Grimshaw, Jane 71

guagua 60

guarango 60

El Guayabo hacienda $\quad 115 \mathrm{f}$

Gullah 150

Gutiérrez-Bravo, R. $\quad 76$ 
$\mathrm{H}$

haber and tener $\quad 51-52$

haciendas 10, 101-102, 106

see also specific haciendas by name

Haiti, distribution of racial groups in 12

Hawkins, R. 73

Highland Ecuador 8

La Huaca hacienda 107-108, 107t

Huaura hacienda 107-108, 107t

Humboldt, Alexander de 136

\section{I}

Ignacio (slave) $\quad 142$

import taxes on slaves 82

Indians

enslavement prohibited 81,85

mit'a system $\quad 88,94$

social status of $85,86 \mathrm{f}$

Infante, Marcos 142

Inter Caetera $80-81$

Interlanguage Hypothese of Creole Formation

Interrogative Clause Condition $\quad 76-77$

intonation patterns $39-40,40 f$

\section{J}

Jesuits 103-110, 106-107t, 109f, 113-114, 118-119, 144

Jesús, Dionisia de 102

Joaquín (slave) 143

jornaleros 99-100

Josefa Olivares, María 100

Justinian code see Corpus Juris Civilis (CJC)

\section{K}

Kikongo language $\quad 29,77-78 \mathrm{n} 13$

L

La Huaca hacienda 107-108, 107t

ladinos $80 n 15,82,86,102$

Land Reform 116

latinos, defined $816 \mathrm{n} 2$

Laurence, K. 11

lawsuits, right to bring $100,122,124,127-128,133$, 142, 146-147

lawyers for blacks $100,123 n 38,124,137,143-144$

Legal Hypothesis of Creole Genesis

overview 119-121, 120n36, 147, 156-157, 161

Afrogenesis Hypothesis compared 151-152

in Barbados 151

Chocó case study $\quad 152-156,154 \mathrm{t}$

Cuba case study $147-150$
Dutch slave law 131-132

English slave law $\quad 126-128$

French slave law 129-131, 129n40, 130n41

law in books versus in action 134

Peru and 146-147

Portuguese slave law $\quad 133-134$

Roman slave law 121-123, 126

in South Carolina $\quad 150-151$

Spanish colonies as less harsh than others 136-139

Spanish practice of slavery $\quad 42 \mathrm{n} 42,139-145$

Spanish slave law 123-125, 161

Legía, Roberto 115

Lex Aelia Sentia $\quad{ }_{123 n} 38$

Lex Fufia Caninia $\quad 123 n 38$

Leyes de Indias $120,123,125,142$

libertad de vientres law 111

Lima 92t, 93, 97

Lima/central coastal zone 24-25

limited access model 14, 18, 152-153, 159-16o

see also Afrogenesis Hypothesis

lingo 60

The Linguistic Legacy of Spanish and Portuguese

(Clements) 11-12, 12t

linguistic shifts 61

Lipski, J.

Afrogenesis Hypothesis and 16,20

Afro-Hispanic features 68

Afro-Yungueño Spanish and 117

bare nouns $\quad 47-48$

basis for analysis 23,26

decreolization of Spanish 8

loss of word-final / / / 31

on need for more research $\quad 18-19$

neutralization of / $/$ / and /1/ 33

number agreement in noun phrases 42

paragogic vowels 28-29

Peruvian dialectal zones 25

pleonastic prepositions $d e$ and $a \quad 53$

velarization of $/ \mathrm{n} / 37$

weakening of syllable-final /s/ 30

yeísmo and /j/ weakening 37

Lockhart, J. 88-90, 94

López de Cerrato, Alonso 85

Lucena Salmoral, M. 138

lumbé 60

M

Macera, P. 104, 113

MacLean y Estenos, R. 98

macuco 60 


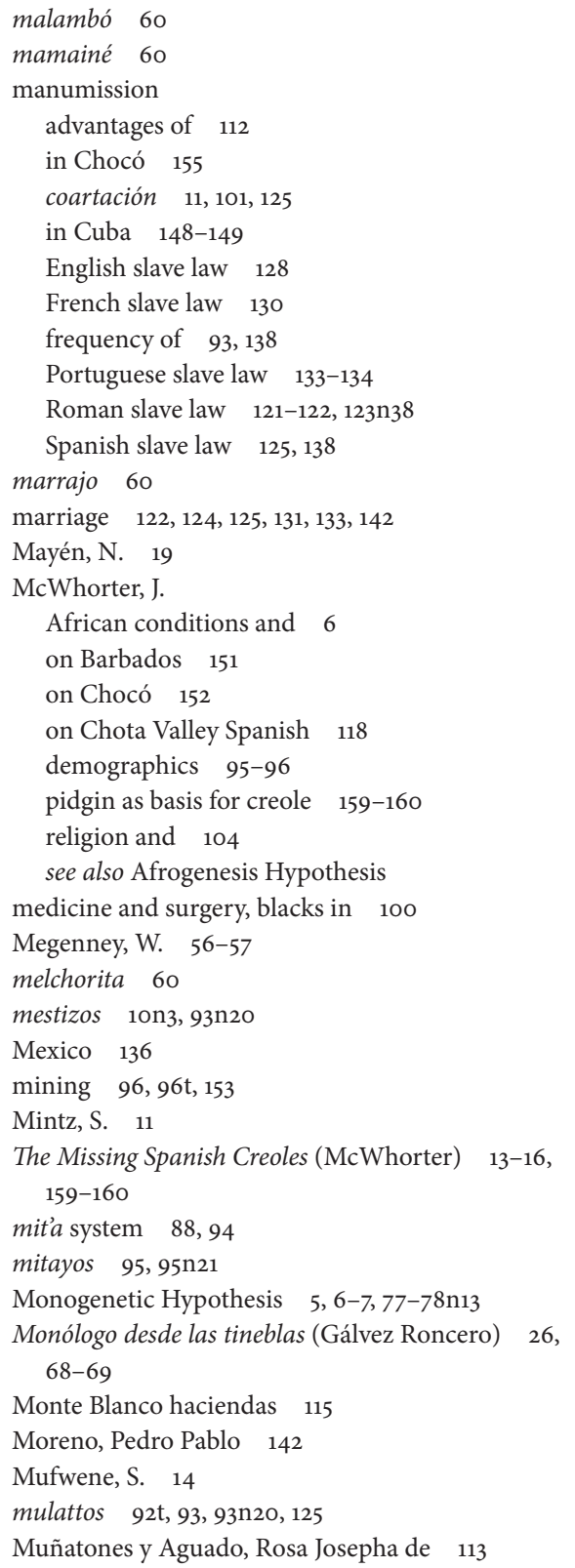

\section{$\mathrm{N}$}

ñacudo, 60

nativization of advanced second language grammars theory see advanced conventionalized second language ñeque 60
Netherlands 131-132

New Laws of 1542-43 85

non-emphatic subject pronouns $69 \mathrm{t}$

non-redundant plural marking $\quad 41-42$

Northern Peruvian coastal zone 25

noun phrases

bare nouns $\quad 47-48$

gender agreement $\quad 42-47,44 t, 45 \mathrm{f}$

number agreement $\quad 40-42$

null subjects 71

number agreement in noun phrases $40-42$, 69-7ot, 72-73

Núñez Ponte, J. 137

ñuto 60

O

Ordenações filipinas 133

ordinances (placaaten) 131-132

Ortiz, Fernando 137-138

overt subject pronouns $\quad 71$

$\mathbf{P}$

palangana 60

Palenquero 5, 9, $121 n_{37}$

Papiamentu 5

paragogic vowels $\quad 28-29$

Paraguay 136

pays de droit coutumier (customary law) 129

pays de droit écrit (written law) 129

peculium 122, 125, 130, 132, 134

Peñaherrera de Costales, P. 17

Pérez-Inofuentes, D. 117

Perl, M. 8, 56, 67

Peru 19-20, 23-26, 59

phi-features 72

pichingo 60

pidgin

as early SLA stage 65

formation of 15

on plantations 14

Spanish pidgin not forming $\quad 6,159-160$

piezas 98

Pizarro, Francisco 82

placaaten (ordinances) 131-132

Plag, I. 65

plantation system $10,12 \mathrm{n} 6,14$

see also haciendas

pleonastic prepositions $d e$ and $a \quad$ 53-54

plurality 40-42

Popayán $153,154 t$

Portugal 81, 133-134 
postnominal adjectives $\quad 43-47,44 t, 45 f$

Potosí area 96

pregoneros (criers) 90, 9of

prepositional phrases $53-55$

pro 71

Processability Theory 65

protector de negros $\quad 100,123 \mathrm{n} 38,124,137,143-144$

\section{Q}

quimba 60

Quimba, fa, malambó, ñeque: Afronegrismos en el Perú (Romero) 59

\section{R}

reflexive se 52

Reglamiento Interior de las Haciendas de la Costa (Coastal Haciendas' Internal Regulation) $111-112$

regularization of irregular verb forms $\quad 48-49$

religion 139-141, 155

see also Jesuits

Restall, M. 85, 91

resyllabification 27

Roman slave law $\quad 121-123$

Romero, F.

Afrogenesis Hypothesis and 20

basis for analysis 23, 26

lexical items 59

loss of word-final / $/ \mathrm{s} \quad 31$

neutralization of / $/$ and /d/ in syllable-initial position 32

neutralization of / $/$ / and /l/ 33, 34

paragogic vowels 28-29

velarization of $/ \mathrm{n} / \quad 37-38$

vowel variability 27

weakening and deletion of /b/,/d/, /g/ 38

weakening of syllable-final /s/ $30-31$

yeísmo and $/ \mathrm{j} /$ weakening $\quad 36-37$

rufa 60

Ruiz-García, M. 18

\section{$\mathrm{S}$}

Salazar, Andrés de 113

Salazar y Muñatones, Augustín de 113

Salguero, Jeronimo José 136

Samek-Lodovici, Vieri 71

San Basilio de Palenque 121, $121 n 37$

San José hacienda 113,115, $115 \mathrm{f}$

San Juan hacienda 107-108, 107t

San Regis hacienda $113,115 \mathrm{f}$
Sandoval, Alonso de 6-7

Schumann, J. H. 65

Schwegler, A. $8,12 \mathrm{n} 6,16,42 \mathrm{n} 42,77-78 \mathrm{n} 13,117$, $121 n 37,13$ on 41

Schwenter, S. $\quad 77-78 \mathrm{n} 13$

se 52

Second Language Acquisition (SLA)

bare nouns and 74-75

creole and 65

first language and 66

gender and number features $\quad 73-74$

invariant verb forms for person and number $\quad 72-73$

overt subject pronouns $\quad 71$

phi-features and 72

subject-verb agreement issues 58

see also advanced conventionalized second language

ser and estar 50-51

serfs 119-12on35, 129

Sharp, William 153-155

Siete Partidas 119-120n35, 120, 123-124

SLA see Second Language Acquisition (SLA) slave fields (chacras de esclavos) 102-103, 105

Slavery on the Spanish Frontier: The Colombian

Chocó (Sharp) 153-155

slaves and slavery

overview $79-80$

abolition of 111-112

American conquest and $80-81$

asientos $81,82,99$

bozales 10, 8on14, 154t, 816n2

in coastal region $\quad 94-98,96 \mathrm{t}, 101$

conquerors and settlers allowed to import 82 , $83 \mathrm{f}$

creole and 97, 97n24, 98, 108, 110

demographics $85-86,88 \mathrm{t}, 91-93$, 92t, 95-96, 112

food for 102-103, 104-105

García, Juan $83-85,84 \mathrm{t}$

in highlands 96

Jesuits and 103-110, 106-107t, 109f, 118-119

life span of $113-114$

limited numbers owned by one person $\quad 98-99$, $99 f$

mining and $96,96 \mathrm{t}$

as mobil capital 98

numbers imported affecting creolization 10 , 160

prestige of owning $\quad 85,88$ 
promises of freedom for enrolling in wars

111-112

proper names not used in reports 82

protector de negros for $100,123 \mathrm{n} 38,124,137$,

143-144

purchase of freedom by 93

ratio to freemen and whites $11-12,12 \mathrm{n} 6,82$,

$93,101,153$

serfs compared 119-120n35

shift to larger haciendas 101-102

skills training for 89-91

social status of $85,86 \mathrm{f}$

Spanish policy on 15

Temporalidades council and 110

trade routes for $87-89,89 \mathrm{f}$

uprisings by $110-111,149$

in urban areas 98

uses for $83-85,99-100$

Valiente, Juan $\quad 83-85,84 \mathrm{t}$

during War of Independence 115

see also Legal Hypothesis of Creole Genesis;

manumission

Slavs 119-120n35

société d'habitation 10

socio-demographic research, importance of 9

Sotomayor Roggero, C. 114

South Carolina 127-128, 150-151

southern coast/south-western Andean zone 25 Spain

division of Americas with Portugal 81

practice of slavery by $\quad 42 \mathrm{n} 42,136-145$

slave laws $123-125,161$

slave trade and 15

Spanish creole debate

overview 5

Afrogenesis Hypothesis $\quad 6,13-21$

decreolization $\quad 6-10$

demographic and economic factors 5-6, $11-13,15$

limited access model 14

Monogenetic Hypothesis $\quad 5,6-7$

Spanish pidgin, as not forming $6,159-160$

status of Afro-Peruvian Spanish

overview $63-64,64 \mathrm{f}$

as advanced conventionalized second language $64,71-77$

features of Afro-Hispanic dialects and $67-70$, $69-70 t$

morpho-syntactic phenomena $\quad 67-70,70 t$

regions of Afro-Hispanic varieties $\quad 67,68 \mathrm{f}$
Stevenson, W. B. $\quad 145-146$

strong quantifiers $\quad 43-47,44 t, 45 f$

subject-verb agreement $\quad 57-58,69 t, 72-73$

subject-verb inversion in questions $\quad 58-59,76$

substrate transfer 65

sugarcane plantations $101-103,109 f, 113-115$,

$147-148$

surgery and medicine, blacks in 100

suró 60

\section{$\mathrm{T}$}

tacutacu 60

taita 60

Tannenbaum, Frank 153

Temporalidades council 110

tener and haber 51-52

third person singular $\quad 72-73$

Torres Saldamando, E. $\quad 81-82$

transgenerational language shift 61

Treaty of Tordesillas 81

Trinidad, José de la 100, 146

$\mathrm{U}$

újele 61

United Provinces of the Netherlands 131-132

Universal Grammar (UG) $\quad 66,75$

V

Valiente, Juan $\quad 83-85,84 \mathrm{t}$

Valle y Osma, Catalina del 115

Venezuala $17,117,136$

verb phrases $\quad 48-52$

Viceroy Count of Monclova 98

vineyards, slaves working in 95

Virgen del Carmen 60

Visigoth Code 133

voting 79

vowel lengthening $\quad 26-28$

vowel rising $27-28$

vowels $26-29$

W

War of Independence 115

War of the Pacific 115

Watson, A. 126-134

weak quantifiers $43-47,44 t, 45 f$

White, L. 73

wh-op (fronted wh-operators) 75-77

written law (pays de droit écrit) 129 
Y

yanaconas $95,95 \mathrm{n} 22$

yújele 61
Z

zapatear 61

zarandango 61

Zavala, Petronilla 115

Zorita, Catalina de 91 
The present work not only contributes to shedding light on the linguistic and socio-historical origins of Afro-Peruvian Spanish, it also helps clarify the controversial puzzle concerning the genesis of Spanish creoles in the Americas in a broader sense. In order to provide a more concrete answer to the questions raised by McWhorter's book on The Missing Spanish Creoles, the current study has focused on an aspect of the European colonial enterprise in the Americas that has never been closely analyzed in relation to the evolution of Afro-European contact varieties, the legal regulations of black slavery. This book proposes the 'Legal Hypothesis of Creole Genesis', which ascribes a prime importance in the development of Afro-European languages in the Americas to the historical evolution of slavery, from the legal rules contained in the Roman Corpus Juris Civilis to the codes and regulations implemented in the different European colonies overseas. This research was carried out with the belief that creole studies will benefit greatly from a more interdisciplinary approach, capable of combining linguistic, socio-historical, legal, and anthropological insights. This study is meant to represent an eclectic step in such a direction.

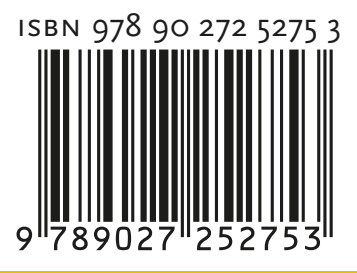

